Portland State University

PDXScholar

$12-30-2020$

\title{
Inventory of Rock Glaciers in the American West and Their Topography and Climate
}

\author{
Allison Reese Trcka \\ Portland State University
}

Follow this and additional works at: https://pdxscholar.library.pdx.edu/open_access_etds

Part of the Geology Commons, and the Geomorphology Commons Let us know how access to this document benefits you.

\section{Recommended Citation}

Trcka, Allison Reese, "Inventory of Rock Glaciers in the American West and Their Topography and Climate" (2020). Dissertations and Theses. Paper 5637.

https://doi.org/10.15760/etd.7509

This Thesis is brought to you for free and open access. It has been accepted for inclusion in Dissertations and Theses by an authorized administrator of PDXScholar. Please contact us if we can make this document more accessible: pdxscholar@pdx.edu. 
Inventory of Rock Glaciers in the American West and Their Topography and Climate

by

Allison Reese Trcka

A thesis submitted in partial fulfillment of the requirements for the degree of

Master of Science

in

Geology

Thesis Committee:

Andrew G. Fountain Chair

Adam Booth

Martin Lafrenz

Portland State University

2020 


\begin{abstract}
Rock glaciers are flowing geomorphic landforms composed of an ice/debris mixture. A uniform rock glacier classification scheme was created for the western continental US, based on internationally recognized criteria, to merge the various regional published inventories. A total of 2249 rock glaciers (1564 active, 685 inactive) and 7852 features of interest were identified in 10 states (WA, OR, CA, ID, NV, UT, ID, MT, WY, CO, NM). Sulfur Creek rock glacier in Wyoming is the largest active rock glacier $\left(2.39 \mathrm{~km}^{2}\right)$. The mean area and elevation for active and inactive rock glaciers are $0.18 \mathrm{~km}^{2}, 3384 \mathrm{~m}$; and $0.20 \mathrm{~km}^{2}, 3072 \mathrm{~m}$, respectively. Mean elevation increases from the northwest in Washington State, $\sim 1670 \mathrm{~m}$ to the southeast, in Colorado $4100 \mathrm{~m}$. Rock glaciers are found in climates with similar temperatures, $\pm 1^{\circ} \mathrm{C}$, and drier $\sim 50 \%$ compared to alpine glaciers. Few rock glaciers occur in locations where precipitation exceeds $1200 \mathrm{~mm}$. The total volume of ice in rock glaciers in the western US is about $6.99 \pm 0.278 \mathrm{~km}^{3}$, which is about half of that contained in the glaciers, $12.37 \mathrm{~km}^{3}$.
\end{abstract}




\section{Acknowledgments}

Special thanks to my advisor, Andrew G. Fountain, who was always there to offer me good humor as well as guidance and direction whenever I ran into a trouble spot. Thank you to my committee members, Adam Booth and Martin Lafrenz, for their time and feedback. I have appreciated the time spent in and out of the office with my fellow grad students. As well as Bryce Glenn and Julian Cross of the Glaciers Research group for being there to bounce ideas off and to commiserate with. I am grateful to my parents and brother for providing me with unfailing support and continuous encouragement throughout the years. 


\section{Table of Contents}

\begin{tabular}{|c|c|}
\hline \multicolumn{2}{|c|}{ 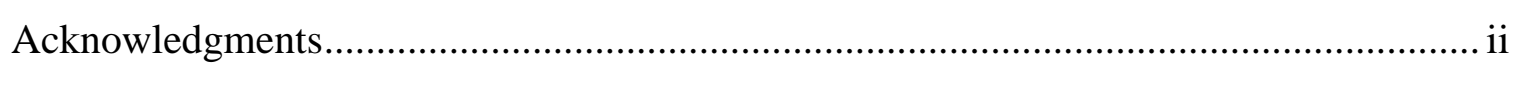 } \\
\hline \multicolumn{2}{|c|}{ 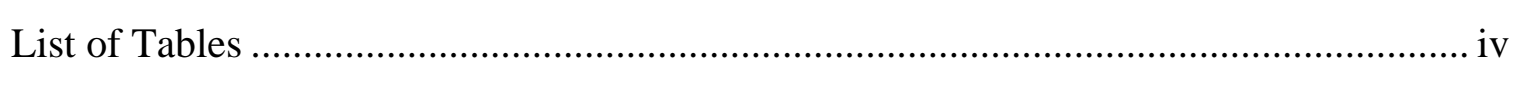 } \\
\hline \multicolumn{2}{|c|}{ 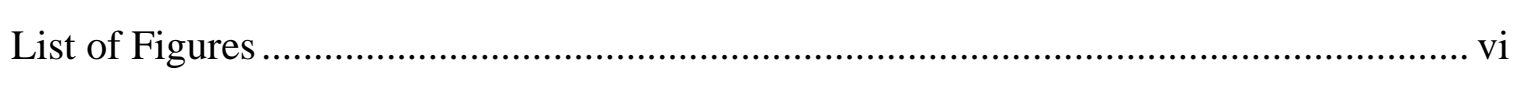 } \\
\hline \multicolumn{2}{|c|}{ 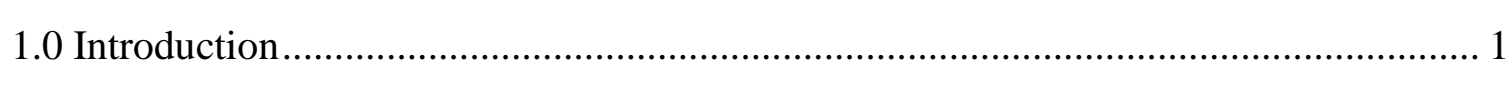 } \\
\hline \multicolumn{2}{|c|}{ 2.0 Background... } \\
\hline \multicolumn{2}{|c|}{ 3.0 Study Area . } \\
\hline \multicolumn{2}{|l|}{ 4.0 Methods... } \\
\hline \multicolumn{2}{|c|}{ 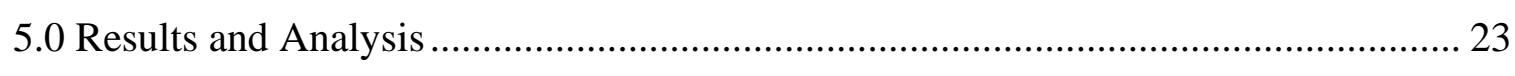 } \\
\hline \multicolumn{2}{|c|}{ 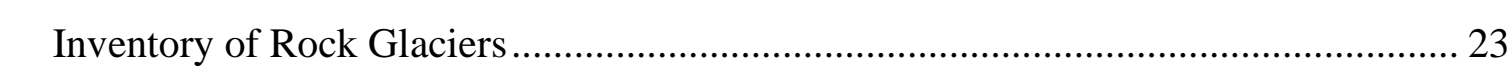 } \\
\hline \multicolumn{2}{|c|}{ Topographic Characteristics ....... } \\
\hline \multicolumn{2}{|c|}{ Climate ................................... } \\
\hline \multicolumn{2}{|c|}{ Comparison with Alpine glaciers.... } \\
\hline \multicolumn{2}{|c|}{ 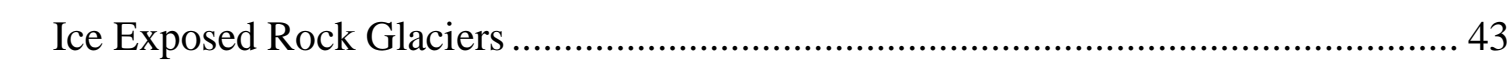 } \\
\hline \multicolumn{2}{|c|}{ 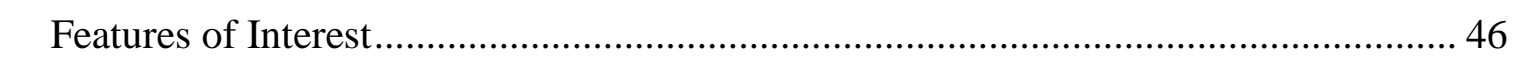 } \\
\hline \multicolumn{2}{|c|}{ 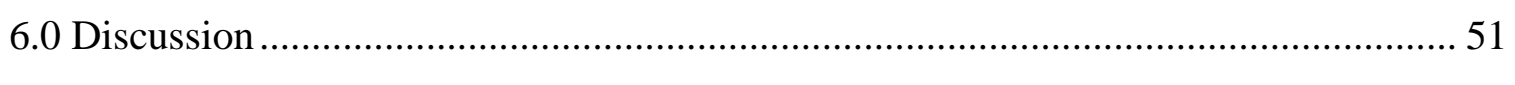 } \\
\hline \multicolumn{2}{|c|}{ 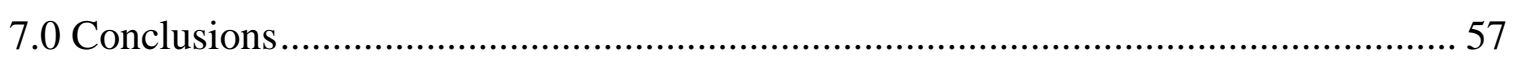 } \\
\hline \multicolumn{2}{|c|}{ 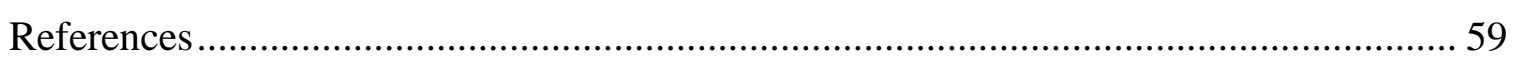 } \\
\hline Appendix A & 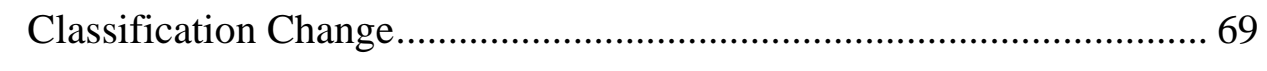 \\
\hline Appendix B & Comparisons with Regional Inventories ............................................. 77 \\
\hline Appendix C & 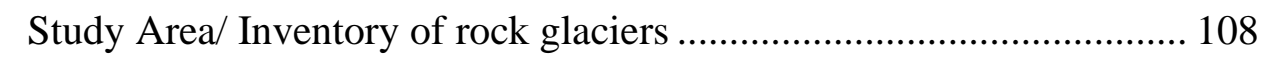 \\
\hline Appendix D & Topographical Characteristics...... \\
\hline Appendix E & Climate ........................... \\
\hline Appendix F & Features of Interest (FOI) ..... \\
\hline Appendix G & 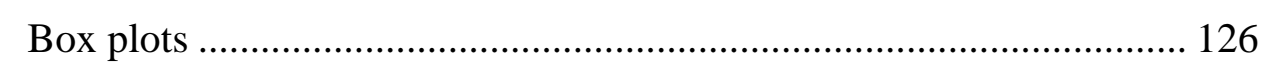 \\
\hline
\end{tabular}




\section{List of Tables}

Table 5-1: A comparison of the number and classification of rock glaciers between the regional inventories and this study. "Features" is the number of rock glaciers-like features identified by the regional inventories. "Rock Glaciers" is the number of features in the regional inventory that I identified as rock glaciers. "FOI" is the number of features reclassified as features of interest. "Eliminated" is the number of features eliminated from the regional inventory. "Added" is the number of rock glaciers missing from the regional inventory. "Total" is the number of rock glaciers for the region. Riffle, 2018 is located in the Cascade Range in Washington, Millar and Westfall, 2019 in the Great Basin, Johnson et al., 2007 in the Lemhi Range in Idaho, Legg, 2018 in Glacier National Park, Montana, Florentine et al., 2014 in the Beartooth and Absaroka Ranges in southern Montana/ northern Wyoming, Kinworthy, 2016 in New Mexico, and Johnson, 2018 in the western US.

Table 5-2: Comparison between subclassification of the regional inventories and my study. Sum is the sum of Active and Inactive. 25

Table 5-3: The area of active and inactive (in parenthesis) rock glaciers in each state... 26

Table 5-4: The elevation of active and inactive (in parenthesis) rock glaciers in each state. Max is the maximum, and Min is the minimum.

Table 5-5: Mean and standard deviation (Std Dev) of topographical characteristics of active and inactive rock glaciers. Bold represent characteristics that are statistically significant (t-test, p-value $<0.05$ ).

Table 5-6: Mean and standard deviation (Std Dev) of climate characteristics of active and inactive rock glaciers. Bold represent statistically significant values (t-test, $\mathrm{p}$-value < 0.05). Temp is temperature in ${ }^{\circ} \mathrm{C}$ and Precip is precipitation in $\mathrm{mm}$.

Table 5-7: Whole-rock glacier ice contents. Range (\%) represents different rock glaciers. Mean (\%) is the mean of the ranges in Range (\%). Technique is how the ice content is found. GPR is ground penetrating radar, BH is borehole, $\mathrm{SR}$ is seismic refraction, $\mathrm{G}$ is gravimetry, GE is geoelectric.

Table 5-8: Summary of rock glacier ice volume in each state. Number is the number of rock glaciers in each state.

Table 5-9: Mean and standard deviation (Std Dev), of topographic characteristics of alpine glaciers and active and inactive rock glaciers. Bold represent values that are statistically different from alpine glaciers (t-test, $\mathrm{p}$-value $<0.05$ ). 
Table 5-10: Mean and standard deviation (Std Dev), of climatic characteristics of alpine glaciers and active and inactive rock glaciers. Bold represent characteristics that are statistically different from alpine glaciers ( $t$-test, $\mathrm{p}$-value < 0.05). Temp is temperature in ${ }^{\circ} \mathrm{C}$ and Precip is precipitation in $\mathrm{mm}$.

Table 5-11: Elevation and area ice exposed rock glaciers (IERG) per state. Max is maximum, Min is minimum.

Table 5-12: Mean and standard deviation (Std Dev), of topographic characteristics of ice exposed rock glaciers (IERG), alpine glaciers and active and inactive rock glaciers. Bold represent characteristics that are statistically different from IERG ( $t$-test, p-value < 0.05).

Table 5-13: Mean and standard deviation (Std Dev), of climatic characteristics of ice exposed rock glaciers (IERG), alpine glaciers and active and inactive rock glaciers. Bold statistically significant differences from IERG ( $\mathrm{t}$-test, $\mathrm{p}$-value < 0.05). Temp is temperature in ${ }^{\circ} \mathrm{C}$ and Precip is precipitation in $\mathrm{mm}$. 46

Table 5-14: The number of features of interest (FOI) in each state.

Table 5-15: Mean and standard deviation (Std Dev), of topographical characteristics of features of interest (FOI). Bold represent values that are statistically different (t-test, $\mathrm{p}$ value $<0.05)$ from the FOI.

Table 5-16: Mean and standard deviation (Std Dev), of climate characteristics of features of interest (FOI) and active and inactive rock glaciers. Bold represent characteristics that are statistically different from FOI (t-test, $\mathrm{p}$-value $<0.05$ ). Temp is temperature in ${ }^{\circ} \mathrm{C}$ and Precip is precipitation in $\mathrm{mm}$. 50

Table 6-1: Comparisons between this study and international rock glacier inventories. Num is number of rock glaciers Mean and Total areas refer to active or intact rock glaciers. Class is the classification used by the authors.

Table 6-2: Comparison between this study to international rock glacier inventories of rock glaciers $(\mathrm{RG})$ and alpine glaciers $(\mathrm{AG})$. 


\section{List of Figures}

Figure 2-1: A rock glacier with ridges and furrows and a steep front (San Juan Mountains, $37.99384^{\circ},-107.8009^{\circ}$ ). Image source: Google Earth Pro.

Figure 3-1: Shaded relief map of the study region, the western United States. Dashed enclosed lines indicate the three major alpine regions, solid enclosed lines indicate regions where regional rock glacier inventories exist.

Figure 4-1: Examples of active (a,b) and inactive (c,d) rock glaciers, (a): BoiseSawtooth-Pioneer Ranges, Idaho, 43.917719 ${ }^{\circ},-114.5983^{\circ}$; b): Sierra Nevada, California, $37.034^{\circ},-118.419^{\circ}$ ); (c): Sierra Nevada, California, $37.58664^{\circ},-118.9458^{\circ}$; d): Beartooth

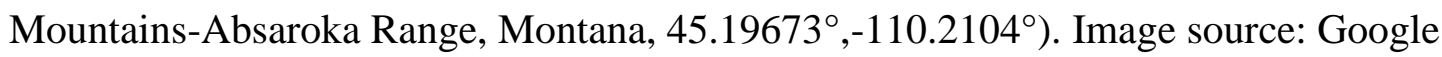
Earth Pro.

Figure 4-2: Features of Interest showing no indications of down-valley flow. (left: Northern Cascades, Washington,48.926651 ${ }^{\circ},-120.704803^{\circ}$; right): Unita Mountains, Utah, $\left.40.759979^{\circ},-110.3304667^{\circ}\right)$. Image source: Google Earth Pro.

Figure 5-1: Examples of features that a) do not extend into the valley (BeartoothAbsaroka Range, Montana, 45.13638,$-109.4715^{\circ}$ ) and $b$ ) does extend into the valley (Boise-Sawtooth-Pioneer Ranges, Idaho, $43.9051^{\circ},-114.4916^{\circ}$ ). Image source: Google

Earth Pro. 24

Figure 5-2: The distribution of rock glaciers across the western United States. 26

Figure 5-3: Overlapping histograms with the topographic characteristics of active and inactive rock glaciers for area (a), elevation (b), aspect (c), aspect and minimum elevation (d), and slope (e). Each interval is denoted by the highest value in each interval. Area is in intervals of $0.09 \mathrm{~km}^{2}$. Elevation is in intervals of $100 \mathrm{~m}$. Aspect is in intervals of $30^{\circ}$. Slope is in intervals of $2.5^{\circ}$.

Figure 5-4: Elevation trends of rock glaciers along two north south transects (top) and two east-west transects (bottom).

Figure 5-5: Total winter precipitation and summer temperature for active (top) and inactive (bottom) rock glaciers in the western US. Rock glaciers with winter precipitation greater than $1500 \mathrm{~mm}$ are in and around the Cascade mountains of Washington, and ones with summer air temperatures greater than $15^{\circ} \mathrm{C}$ are in New Mexico.

Figure 5-6: Overlapping histogram of the mean insolation of active and inactive rock glaciers (top). Each interval is denoted by the highest value in each interval, with 
intervals of $160000 \mathrm{WHm}^{-2}$. Grey dots represent rock glaciers (active and inactive) and line is a fourth order polynomial regression of mean insolation and aspect (bottom)...... 32

Figure 5-8: Climatic trends of rock glaciers in Colorado, including their latitude and longitudinal positions (top left), the relationship with mean elevation (top right), and the relationship with mountain ranges for active and inactive.

Figure 5-9: Climatic trends of rock glaciers along two north south transects; Washington through California (left) and Montana through New Mexico (right). 35

Figure 5-10: Climatic trends of rock glaciers along two east west transects; Washington through Montana (left) and California though Colorado (right). 36

Figure 5-11: Total area and number of rock glaciers and alpine glaciers in each mountain range. 39

Figure 5-12: Overlapping histograms with the topographic characteristics of alpine glaciers, active and inactive rock glaciers for elevation (a), elevation and total area (b), aspect (c), slope (d), and area (e). Each interval is denoted by the highest value in each interval. Area is in intervals of $0.09 \mathrm{~km}^{2}$. Elevation is in intervals of $100 \mathrm{~m}$. Aspect is in

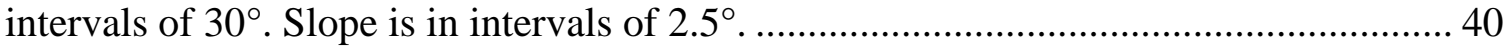

Figure 5-13: Climate of alpine glaciers in relation to elevation and rock glaciers.

Figure 5-14: Average temperature and precipitation of all alpine glaciers and rock glaciers for each mountain range.

Figure 5-15: The topographic characteristics of ice exposed rock glaciers (IERG), active and inactive rock glaciers and alpine glaciers for elevation (a), aspect (d), slope (d), and $\operatorname{area}(\mathrm{d})$.

Figure 5-16: Total winter precipitation and summer temperature for ice exposed rock glaciers (IERG), active and inactive rock glaciers, and alpine glaciers in the western US.

Figure 5-17: Distribution of features of interest across the western United States.

Figure 5-18: Number of rock glaciers and features of interest (FOI) in each mountain range.

Figure 5-19: Topographic characteristics of elevation (a), aspect (b), and slope (c) of features of interest (FOI) compared to active and inactive rock glaciers. 
Figure 5-20: Climate of features of interest, and active and inactive rock glaciers........ 50 


\subsection{Introduction}

Glaciers are important features in the alpine landscape. They modify the landscape by eroding bedrock, and by transporting and depositing sediment (Douglas and Evans, 2010; Reheis, 1975; Boulton, 1996). They can be considered as frozen reservoirs that deliver freshwater during hot, dry periods, naturally regulating streamflow variations (Fountain and Tangborn, 1985; Moore et al., 2009). The transfer of water from these reservoirs not only contributes to regional water runoff providing water for industrial, agricultural, and municipal uses but it also contributes to sea level rise (Fountain and Tangborn, 1985; Meier, 1984; Radić et al., 2014). However, glaciers are only one end member in a continuum of perennial ice features that flow.

Rock glaciers are mixtures of rock debris and ice that deform by the long term creep of ice under permafrost conditions (Harrison et al., 2008; Haeberli et al., 1985; Martin and Whalley, 1987). They form in many mountainous regions globally (Barsch, 1996; Jones et al., 2019). Rock glaciers are a generally unrecognized water resource but may become more important in the future as alpine glaciers disappear (Rangecroft et al., 2015; Janke et al., 2015). Ice melt from rock glaciers can be a critical source for alpine streams (Williams et al., 2006; Leopold et al., 2011). Runoff from rock glaciers is distinct from ice-free catchments in two ways. Following rainfall events, catchments with rock glaciers have increased runoff, due to less infiltration of rainfall into the ground (Geiger et al., 2014). Meltwater chemistry also is different, since rock glaciers have a high debris fraction which promotes chemical weathering and leads to solute-enriched water. This makes them an important regulator of bioavailable nutrients and heavy metal 
concentrations in water sources fed by rock glaciers (Fegel et al., 2016; Crespo et al., 2017; Geiger et al., 2014; Thies et al., 2013; Colombo et al., 2018).

Rock glacier inventories are used for a number of reasons. They are used for estimating the volume of water in storage, as ice, for regional hydrological concerns (Rangecroft et al., 2015; Azócar and Brenning, 2010; Clow et al., 2003), and for hazard assessment such as slope destabilization (Lugon and Stoffel, 2010; Roer et al., 2008). The elevation distribution of rock glaciers is often used as a proxy for inferring permafrost limits and the paleoclimate of the region (Barsch, 1996; Krainer and Ribis, 2012; Rangecroft et al., 2014; Refsnider and Brugger, 2007; Colucci et al., 2019). Rock glaciers are also favored pika habitats, as well as provide refugia as the climate warms (Millar and Westfall, 2010; Hafner, 1994).

In the continental US, west of the $100^{\text {th }}$ Meridian, six regional inventories and one comprehensive inventory have been compiled (Kinworthy, 2016; Legg, 2016; Florentine et al., 2014; Johnson et al., 2007; Johnson, 2018; Riffle, 2018; Millar and Westfall, 2019). However, these inventories were separate efforts with no inter-comparison of identification criteria and findings. The purpose of this thesis is to develop a comprehensive rock glacier inventory for the western US, based on criteria from the International Permafrost Association rock glacier action group (Delaloye and Echelard, 2020), using previous inventories as guides and for comparative interpretation. This thesis also examines the environmental conditions (climate, topography) that dictate the presence of rock glaciers. Defining rock glacier area and location will contribute to our understanding of high alpine water resources with important implications for high alpine 
habitats (Millar and Westfall, 2008). Results will contribute to the global inventory of rock glaciers. 


\subsection{Background}

Rock glaciers have been studied since the late 1800s and were considered to be a particular form of talus (Barsch, 1996; Duguay et al., 2015). It was not until 1910 that the term "rock glacier" was first introduced, and their glacier-like movement, due to the deformation of ice within the talus, was first described in 1959 (Wahrhaftig and Cox, 1959; Capps, 1910).

The origin of ice in rock glaciers is unclear, and both periglacial and glacial origins have been proposed (Clark et al., 1998; Barsch, 1996; Whalley and Azizi, 2003; Berthling, 2011; Jones et al., 2018). The periglacial origin argues that ice is found within the void spaces between the rocks, most likely sourced from the freezing of rain/groundwater/snowmelt that percolates through the rock glacier matrix (Capps, 1910; Haeberli et al., 1985; Barsch, 1996; Munroe, 2018). The glacial origin argues that a remnant of an alpine glacier was buried and preserved by an insulating layer of rock debris (Potter, 1972, Steig et al., 1998, Monnier and Kinnard, 2015).

At shallow depths, rock glaciers seasonally thaw and refreeze. This "active layer" consists mostly of unconsolidated angular boulders (Barsch, 1996; Florentine et al., 2014) and is 0.5-10 m thick (Barsch, 1996; Haeberli et al., 2006; Anderson et al., 2018; Barsch, 1996; Florentine et al., 2014; Humlum, 2000). The interior of a rock glacier is ice-rich consisting of either ice-saturated debris, a core of massive ice, or a mixture of both. Some studies found a mixed ice and rock layer over massive ice, and others found mixed ice and rock layers that contain lenses of segregated ice (Steig et al., 1998; Guglielmin et al., 2004; Florentine et al., 2014). This ice-rich layer may be found on top of a base layer 
consisting of overridden rock debris which can be permanently frozen but contains less ice than the overriding layer (Serrano et al., 2006; Krainer et al., 2012; Humlum, 2000). These stratigraphic units can vary spatially and deform at different rates resulting in varied surface morphology (Elconin and LaChapelle, 1997; Arenson et al., 2002).

The formation and preservation of rock glaciers are primarily controlled by geologic, climatic, and topographic variables. (Thompson, 1962). Rock glaciers require talus for their growth which comes from the surrounding headwalls. The size of the headwall, its structure, and weathering patterns affect the rate of talus production. Snow accumulation includes direct deposition, avalanching, and wind transport. Important topographic variables include elevation, which strongly affects air temperature, and aspect which controls total maximum solar insolation, both of which affect snow accumulation and summer melt (Morris, 1981; Johnson et al., 2007; Kenner and Magnusson, 2017; Humlum, 1988; Ikeda and Matsuoka, 2006). The Balch Ventilation process is considered important to maintaining the ice within a rock glacier (Thompson, 1962; Jones et al., 2019; Barsch, 1996). In this process, cold air drains into the pore spaces of the talus replacing any resident warm air, keeping the interior cool. Conversely, warm air, due to its relative buoyancy, cannot readily infiltrate the resident cold air (Jones et al., 2019). Rock glaciers mostly occupy continental climates rather than maritime climates. Continental climate has less precipitation, warmer summer temperatures, and cooler winter temperatures than a maritime climate. The large and relatively warmer winter snowpack of maritime climates insulates talus accumulations, limiting cold air drainage and inhibiting rock glacier formation (Barsch, 1996; Jones et al., 2019). 
Rock glaciers move due to the creep of the internal ice at rates of $10^{-1}-10^{0} \mathrm{~m} \mathrm{yr}^{-1}$ (Kääb et al., 2003; Krainer and Mostler, 2006). This rate is slower than that of alpine glaciers, which move due to creep and basal sliding at rates of 5-20 $\mathrm{m} \mathrm{yr}^{-1}$ (Cuffey and Paterson, 2010). Like glaciers, rock glacier velocities vary spatially, with different parts moving at different speeds, due to underlying topography and variations in thickness (Petersen et al., 2016). The surface moves faster than at depth (Arenson et al., 2002; Anderson et al., 2018). Temporal variation in velocities seems to lag air temperature by three months, increasing from the spring to fall and decreasing in the winter (Liu et al., 2013).

Rock glaciers exhibit three main shapes: lobate, tongue-shaped, and complex (Barsch, 1996; Corte, 1987). Lobate forms have a greater width than length ratio and tongue-shaped have a greater length than width ratio (Hamilton et al., 1995; Johnson et al., 2007). Complex rock glaciers exhibit traits from both of the forms; some are called spatulate which are tongue-shaped but spread laterally when entering a wide valley. Complex rock glaciers can also consist of single or multiple lobes with different levels of activity and ages, rock glaciers may overlap, or multiple rock glaciers may merge (Barsch, 1996; Haeberli et al., 1985).

A rock glacier nominally consists of three parts: erosional zone, depositional zone, and rooting zone (Brardinoni et al., 2019; Müller et al., 2016). The headwall, or erosional zone, supplies the majority of the debris to the rock glacier. The depositional zone, located downslope of the erosional zone, is the main body of the rock glacier where 
the majority of the movement occurs. Between the erosional and depositional zones is the rooting zone, where most of the ice is nourished.

Rock glaciers are typically classified according to their activity, and the vocabulary differs among authors. An "active" rock glacier has internal ice and moves (Barsch, 1996). Rock glaciers that still contain ice but are no longer moving are “inactive” (Barsch, 1996; Lilleøren and Etzelmüller, 2011). Two types of inactivity have been proposed: climatically and dynamically (Barsch, 1996; Janke and Frauenfelder, 2008). Climatically inactive rock glaciers no longer have ice in the upper layers within the front slope, while dynamically inactive rock glaciers extend too far from the rooting zone which reduces the flux of talus and/or ice to the rock glacier (Barsch, 1996; Kellerer-Pirklbauer, 2016). Rock glaciers that no longer contain any ice are commonly called "relict" or "fossil" rock glaciers (Barsch, 1996).

Characteristics of each type of rock glacier, active, inactive, and relict, differ. Active rock glaciers have a steep $\left(\sim>30-35^{\circ}\right)$ and sharp-crested front and lateral slopes (Barsch, 1996; Martin and Whalley, 1987; Jones et al., 2019). The slopes are light colored compared to the darker color of the main surface, indicative of different magnitudes of weathering (Jones et al., 2019; Barsch, 1996; Martin and Whalley, 1987; Krainer and Ribis, 2012). Inactive rock glaciers have a gentler and less sharp-crested front and lateral slopes. The slopes are darker colored with some vegetation cover (Barsch, 1996; Kellerer-Pirklbauer, 2016; Johnson et al., 2007). Relict rock glaciers have the gentlest front slope $\left(<30^{\circ}\right)$ and round-crested front and lateral slopes. The slopes are 
also dark-colored with extensive vegetation cover and surface collapse features (Barsch, 1996; Lilleøren and Etzelmüller, 2011).

Rock glaciers are typically identified by their morphology (Barsch, 1996; Janke, 2007). The criterion that is almost universally used is over-steepened front and lateral margins, which indicates movement and possible internal ice (Arenson et al., 2002; Anderson et al., 2018; Humlum, 2000; Delaloye and Echelard, 2020). Other common criteria are ridges and furrows, smooth surfaces, and vegetation, however, they are not common to all rock glaciers (Figure 2-1). Ridges and furrows are thought to be indicators of past and present movement; however, no empirical evidence for such a conclusion exists. They are thought to form one of two ways, exogenous or endogenous (Barsch, 1996; Florentine et al., 2014; Frehner et al., 2015). The exogenous model suggests that ridges and furrows form from variations in the debris input (Barsch, 1996; Kääb and Weber, 2004), whereas the endogenous model suggests they form from internal processes of compressive flow and/or internal shearing/buckling due to the heterogeneity of rock and ice (Florentine et al., 2014; Frehner et al., 2015). Some characteristics are unique to individual inventories, such as having a smooth surface, forming above certain elevations, or certain length-width ratios (Florentine et al., 2014; Johnson et al., 2007). In other cases, criteria between different inventories are contradictory; for example, ridges and furrows are only found on inactive rock glaciers (Johnson et al., 2007) or found on both active and inactive rock glaciers (Millar and Westfall, 2019; Krainer and Ribis, 2012). Similarly, the vegetation criterion is also contradictory; for example, vegetation is only found on relict rock glaciers (Johnson et al., 2007; Krainer and Ribis, 2012) or found 
on both active and relict rock glaciers (Uxa and Mida, 2017). Vegetation seems to be subject to grain size and stability of the rock glacier, increasing in more stable areas with less significant movement and finer-grained material (Burga et al., 2004; Gobbi et al., 2014). Based on these variable criteria, rock glacier inventories have been compiled for various regions around the world (Jones et al., 2018).

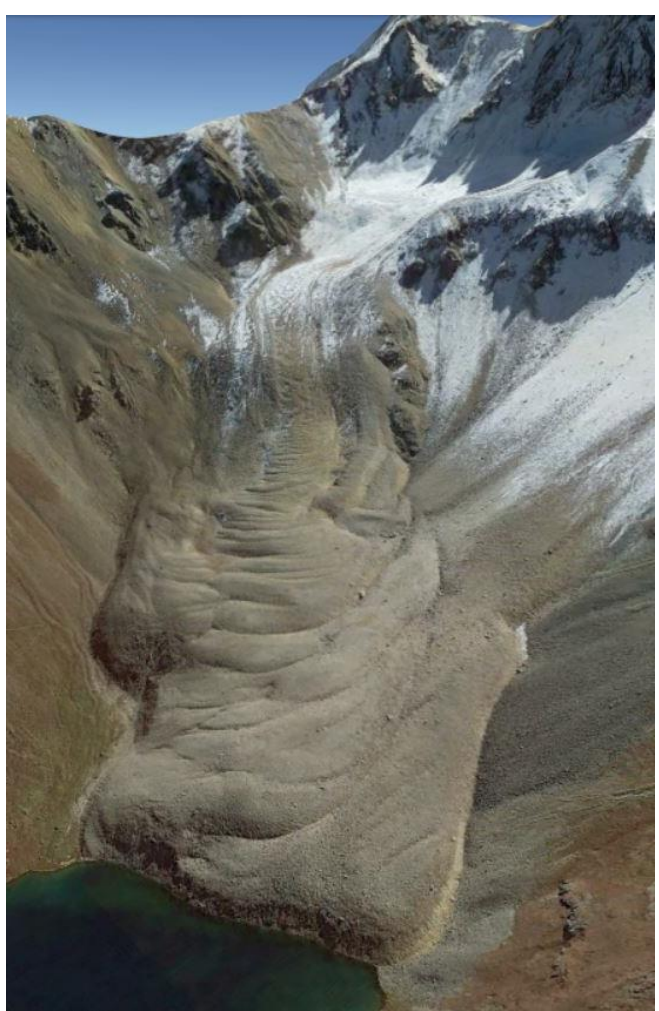

Figure 2-1: A rock glacier with ridges and furrows and a steep front (San Juan Mountains, $37.99384^{\circ}$, $\left.107.8009^{\circ}\right)$. Image source: Google Earth Pro. 


\subsection{Study Area}

The American West, defined by the contiguous states west of the $100^{\circ}$ meridian, is roughly $3,100,050 \mathrm{~km}^{2}$ and includes three major mountain ranges: the Rocky Mountains, the Cascade Range, and the Sierra Nevada Range (Fig. 3-1), all of which are populated by both alpine and rock glaciers (Fountain et a., 2017; Johnson, 2018). The Rocky Mountains are the easternmost range extending from Canada to New Mexico through the states of Montana, Idaho, Wyoming, Utah, Colorado, and New Mexico. It is bounded by the Great Plains on the east and the Basin and Range Province and the Columbia River Plateau on the west. The highest elevation in the Rocky Mountains is Mount Elbert, in Colorado, at $4401 \mathrm{~m}$. The Cascade Range extends from Washington to Northern California. It is bounded by the Basin and Range Province and the Columbia River Platea on the east and the Puget-Willamette lowland and the Central Valley on the west with the highest elevation in Washington, Mount Rainer, 4,392 m. The Sierra Nevada, in California, is bounded by the Central Valley on the west and the Basin and Range Province on the east. It has the highest point in the contiguous United States, Mt. Whitney, at 4,421 m.

The climate of the western United States varies greatly. Winter precipitation is controlled by the southward movement of the polar vortex, this moves the Polar Front jet southward which generates moisture from the Pacific Ocean east into the western side of the western US (Davis and Walker, 1992). As these storms move east, they lose moisture passing over mountains creating rain shadows on the eastern side reducing precipitation between the Cascade Range and the Rocky Mountains. Winter high-pressure systems that 
form in the Basin and Range Province cools the center part of the western US (Davis and Walker, 1992; Mitchell, 1976). The cold dry air from the polar continental air masses in Canada moves south and cools the eastern side of the western US in winter while moisture from the Gulf of Mexico moves northward into the eastern side of the western US in summer. Summer air temperature is affected by cool winds blown in from the Pacific Ocean into the western part of the western US as well as into the northwestern part of Montana (Mitchell, 1976). Warm temperatures in the Basin and Range Province, generate a low-pressure system that warm the central part of the western US through Idaho, southern Montana, and Wyoming (Davis and Walker 1992; Mitchell, 1976). Overall, the climate is generally warmer and drier to the south and east from Washington State.

Alpine glaciers are found in all states except Arizona, New Mexico, and Utah, totaling 1276 (Fountain et al., 2017). Most are found in the Pacific Northwest of Oregon, Washington, and Montana, which also has the largest ice-covered area and largest glaciers. The glaciers are generally small with an average of $0.13 \mathrm{~km}^{2}$ and a median of $0.03 \mathrm{~km}^{2}$. Rock glaciers are also relatively common. They have been identified in the same states as alpine glaciers as well as in Utah and New Mexico (e.g. Johnson, 2017; Millar and Westfall, 2019; Kinworthy, 2016).

Rock glacier inventories have been compiled for mountain ranges in Idaho (Johnson et al., 2007), Montana (Florentine, 2014; Seligman, 2009; Legg, 2016), California (Liu et al., 2013; Millar and Westfall, 2008; Millar and Westfall, 2019), Colorado (Brenning et al., 2007; Janke, 2007; Janke and Frauenfelder, 2008; Refsnider 
and Brugger, 2007), New Mexico (Kinworthy, 2016), Nevada (Van Hoesen and Orndorff, 2011), and Utah (Munroe, 2018). One inventory has been compiled for the study region (Johnson, 2018).

These studies each report how they classify and characterize rock glaciers, topographic characteristics, and sometimes information on their climate and movement. In these studies, rock glaciers are classified as active or inactive if they contain ice, or collectively as intact rock glaciers (Johnson et al., 2006, Millar and Westfall, 2019; Charbonneau and Smith, 2018). If there is no or a minimal amount of ice then they are classified as relict. Rock glaciers move at rates of $\mathrm{mm} \mathrm{yr}^{-1}$ and $\mathrm{cm} \mathrm{yr}^{-1}$ (Liu et al., 2013). Within a rock glacier, the spatial pattern of flow is thought to be correlated with surface geomorphic features, with the fastest speeds collocating with ridge and furrow morphology (Liu et al., 2013, Florentine et al., 2014). This characteristic is often used in all studies as well as having over steepened fronts. Studies have compared topographic characteristics between active and relict rock glaciers as well as tongue-shaped and lobate shaped rock glaciers. Active rock glaciers have higher elevations and less solar radiation than relict (Janke and Frauenfelder, 2008; Van Hoesen and Orndorff, 2011). The distribution of rock glaciers is thought to be controlled most by elevation, mean annual air temperature, and less so by precipitation and solar irradiance (Morris, 1981; Humlum, 1988; Johnson et al., 2007; Kenner and Magnusson, 2017). Clearly, elevation and air temperature are climate controls and studies generally agree that rock glaciers from at 
high elevations, with northerly aspects, with mean annual air temperatures less than $2^{\circ} \mathrm{C}$ (Millar and Westfall, 2019; Monroe, 2018).

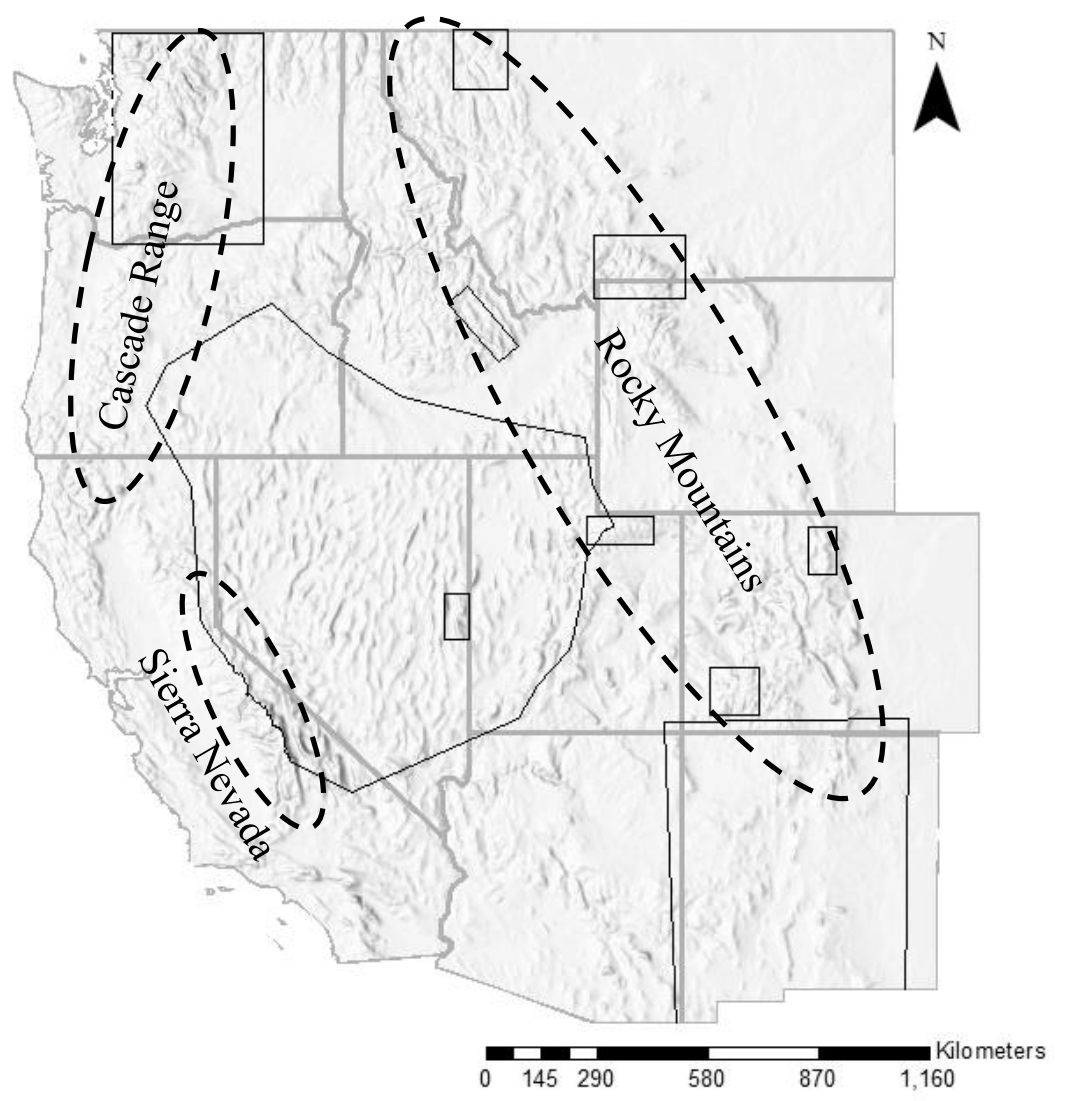

Figure 3-1: Shaded relief map of the study region, the western United States. Dashed enclosed lines indicate the three major alpine regions, solid enclosed lines indicate regions where regional rock glacier inventories exist. 


\subsection{Methods}

Rock glaciers can be identified remotely from aerial or satellite imagery because their morphology is different from other geomorphic features. Their shape (tonguelobate-complex) distinguishes them from solifluction lobes and rock and talus streams (Barsch, 1996), their positive relief differentiates them from blockfields and their lack of scarps differentiates them from landslides (Barsch, 1996; Kinworthy, 2016). However, distinguishing rock glaciers from debris-covered glaciers can be difficult due to ambiguity in definitions, debate in the discipline, and problems typical of transitional landforms. A debris-covered glacier has a layer of rock on most or all of the surface of the ablation zone (Cogley et al., 2011). Any surficial rocky debris up-glacier from the ablation zone (accumulation zone) is buried by snow accumulation and is transported through the glacier body eventually to the ablation zone where it melts out of the ice (Cuffey and Paterson, 2010). Nominally, the transition from the ablation to the accumulation zone (equilibrium line) is at the average elevation of the glacier (Leonard and Fountain, 2003), so if the rock debris extends well above the average elevation how is the feature to be defined? Is it an alpine glacier mantled with rock debris, an alpine glacier transitioning into a rock glacier or a rock glacier with an icy accumulation at the head? Also, should there be a difference in classification if the feature is $90 \%$ covered with rock compared to $75 \%$ covered? I found little or no discussion of this issue in the literature. Rather than make an arbitrary classification of these features I adopted a middle path. If the rock cover extends from the terminus to the mean elevation or less, I classified it as a debris-covered glacier and did not include it in the inventory. If the 
debris extends above the average elevation, it is classified as a rock glacier. If ice is exposed at the head of the feature, denoted as having an off-white/greyish color (compared to white snow) and exhibits crevasses, I included the attribute "ice-exposed rock glacier". The approach allows future users to reclassify these hybrid features if necessary.

An initial rock glacier classification scheme was created by compiling schemes of published regional studies for which feature locations were available and could be examined in Google Earth (Millar and Westfall, 2019; Johnson et al., 2007; Florentine et al., 2014). Unfortunately, Johnson's (2018) classification scheme was not available at the time of this study. The initial scheme consisted of four categories - active rock glaciers, inactive rock glaciers, relict rock glaciers, and features of interest (Appendix A). However, none of the regional inventories explicitly defined a morphology to indicate movement, a critical criterion for rock glacier identification. An illuminating study by Liu et al., (2011) measured the movement of 59 rock glaciers and provided their location allowing me to test and refine my initial classification scheme. Results showed that a number of the morphologies that I used as metrics of movement were not diagnostic, as described earlier, and the categories overlapped (Appendix A). Also, a working document by the International Permafrost Association action group, rock glacier inventories and kinematics, was a major influence by including fewer metrics and categories (Delaloye and Echelard, 2020). Given the uncertainty in visual classification methods, I simplified the scheme into three categories - active and inactive rock glaciers, and features of interest as follows. 
Rock glaciers are accumulations of rock debris and ice that deform by long term creep (Berthling, 2011; Barsch, 1996). They exhibit positive relief, over-steepened lower margins, and indications of movement. Active rock glaciers are moving, inactive rock glaciers are no longer moving and may no longer contain ice. Morphological characteristics for active and inactive categories include (Figure 4-1),

- Extends into the valley from the valley wall or occupies the axis of the valley, an indicator of significant movement.

- Front lower margin and lateral margins:

Front margins are perpendicular to the apparent flow direction

Active rock glaciers - over-steepened slopes, apparently greater than the angle of repose $\left(30^{\circ}\right)$, which indicates movement and possible internal ice;

Inactive rock glaciers - slopes below the angle of repose, which indicates a lack of movement and perhaps lacking ice

- Relief:

Active rock glaciers - appear dilated, which indicates movement and internal ice; Inactive rock glaciers - appear deflated/flattened, which indicates a lack of movement and internal ice.

In addition to active and inactive a subcategory descriptor "ice-exposed rock glaciers" was added if ice was exposed at the head of the feature to denote it may be a hybrid rock/debriscovered glacier. 

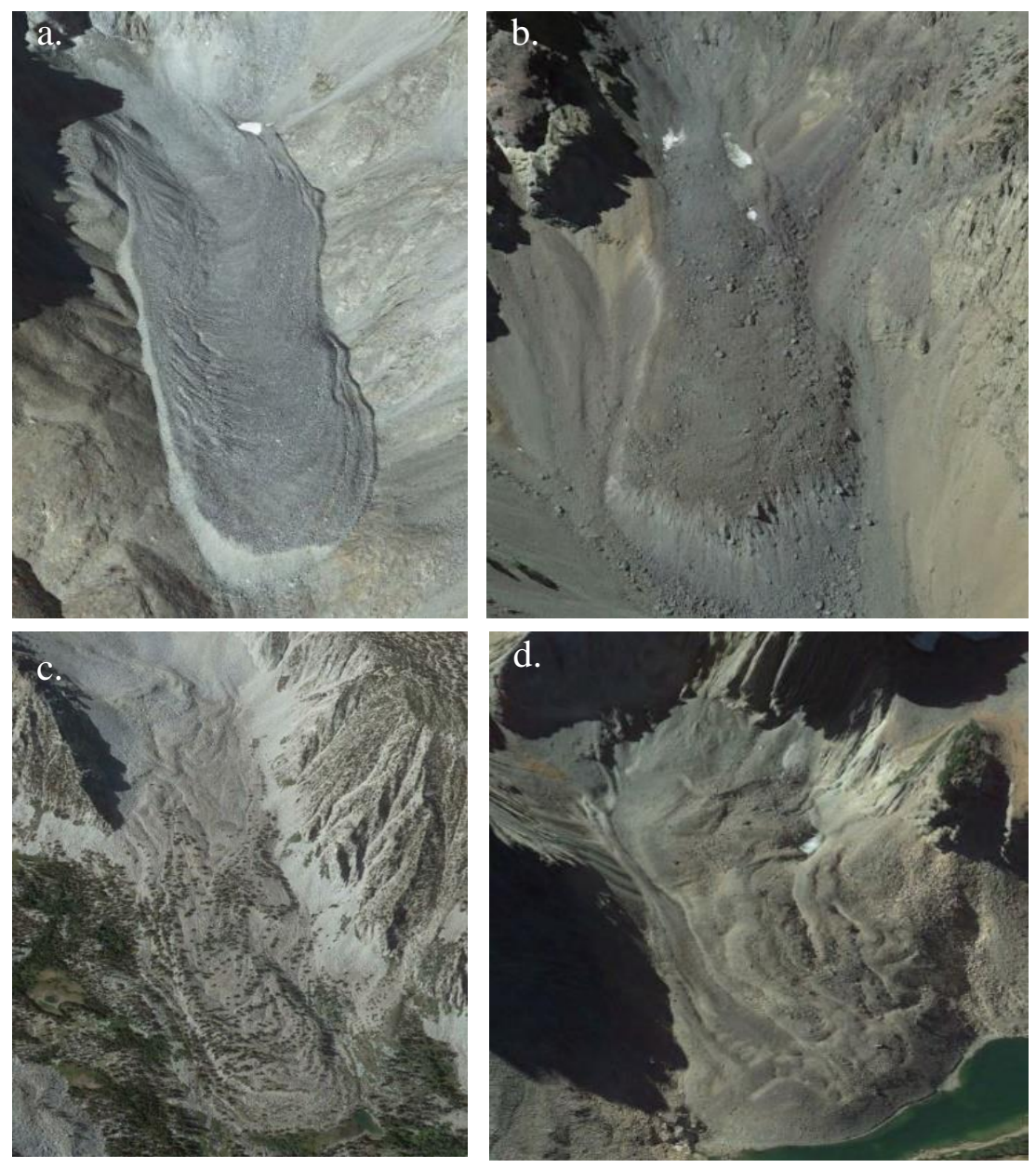

Figure 4-1: Examples of active $(a, b)$ and inactive $(c, d)$ rock glaciers, (a): Boise-Sawtooth-Pioneer Ranges, Idaho, $43.917719^{\circ},-114.5983^{\circ}$; b): Sierra Nevada, California, $37.034^{\circ}$, -118.419 ); (c): Sierra Nevada, California, 37.58664 ${ }^{\circ}$,

$118.9458^{\circ}$; d): Beartooth Mountains-Absaroka Range, Montana, $45.19673^{\circ},-110.2104^{\circ}$ ). Image source: Google Earth Pro.

Features of interest (FOI) are features that have some of the same characteristics of rock glaciers but do not extend out sufficiently from the valley wall to indicated significant movement. I define an FOI as an accumulation of rock debris and ice under permafrost conditions that form at the base of valley walls. They exhibit over-steepened margins with no indications of significant movement. They appear to be more like pro- 
talus ramparts and may be genetically related to rock glaciers (Haeberli, 1985; Barsch, 1996). Morphological characteristics of FOI include (Figure 4-2),

- Accumulation at the base of a valley wall, no indication of significant flow downvalley.

- Over-steepened slopes, apparently greater than the angle of repose $\left(30^{\circ}\right)$

- Exhibits a positive relief ranging from a swollen to a somewhat flattened appearance.
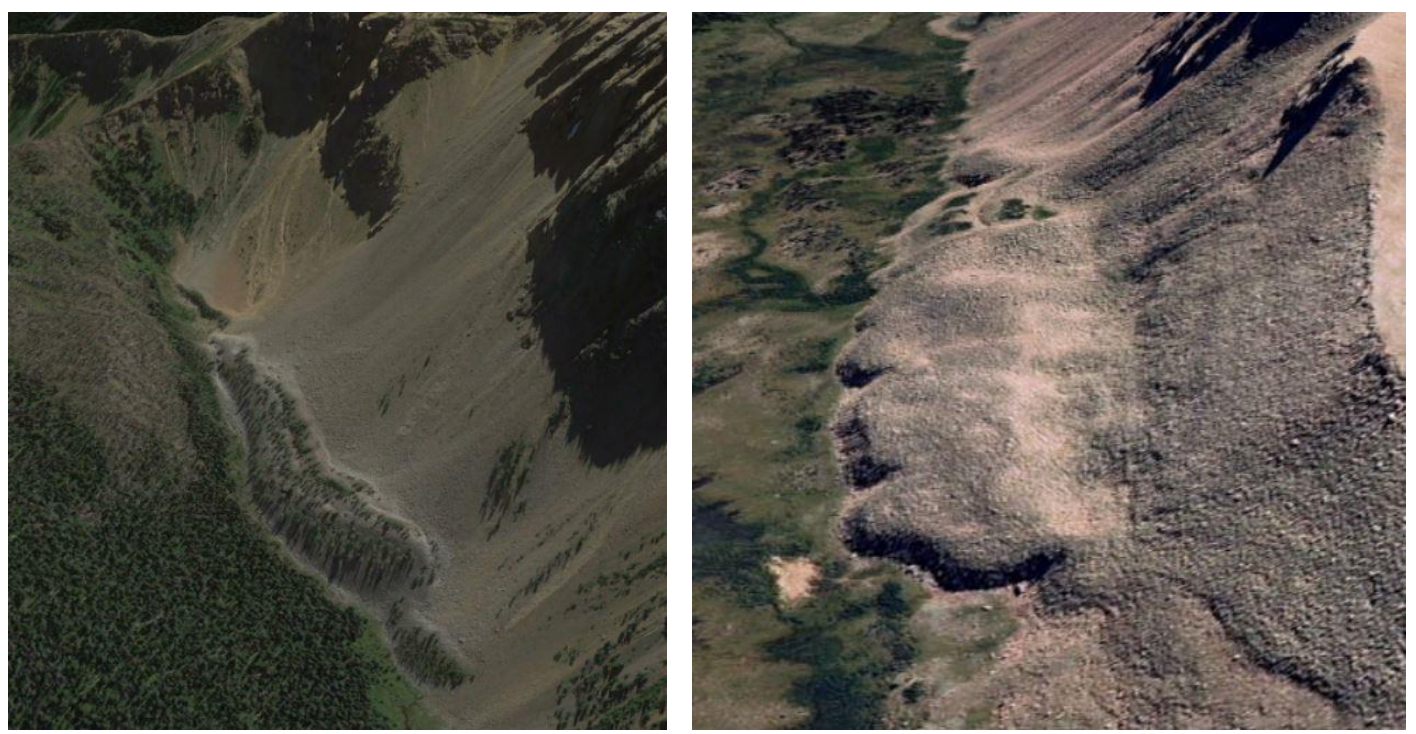

Figure 4-2: Features of Interest showing no indications of down-valley flow. (left: Northern Cascades, Washington, $48.926651^{\circ},-120.704803^{\circ}$; right): Unita Mountains, Utah, $\left.40.759979^{\circ},-110.3304667^{\circ}\right)$. Image source: Google Earth Pro.

My rock glacier inventory is based on Johnson (2018), who compiled the locations of rock glacier-like features across the Western US. I reexamined every feature identified by Johnson (2018) and like Johnson, I used Google Earth Pro (Google LLC, version 7.1.2), an online geographic information system that renders a three-dimensional representation of land surfaces using satellite and aerial imagery superimposed on a digital terrain model. Particularly valuable features in Google Earth Pro were the historic imagery tool and the oblique views. The historic imagery tool allows the user to rapidly 
find the image with the best resolution, clarity, illumination, and minimum snow cover. The time of year, light intensity, and light angle can affect rock glacier identification, and extensive snow cover often masks rock glaciers. The oblique view tool allows the user to customize the perspective, which enhances the ability to interpret a feature. In addition to reexamining Johnson's identifications, I also searched the region for additional features that Johnson may have missed.

Once a rock glacier was identified, its perimeter was digitized and attributes were compiled in ArcMap (ESRI versions 10.6.1-10.7.1). The imagery in ArcMap was similar to those found in Google Earth. Attributes are easier to manipulate in ArcMap than in Google Earth. Digitizing the perimeter was simple along the lower margins because it was typically well-defined, but the upper perimeter at the head of the rock glacier in the rooting zone is vague, as talus blankets and obscures the perimeter. With this in mind, the upper perimeter included the lower portion of the talus blankets, which is above the rooting zone, which may have overestimated the rock glacier area somewhat. For FOI, which are not the focus of this study, they were identified by only a dot to preserve their location for possible subsequent studies. For each rock glacier and FOI, several attributes were recorded, including source inventory (e.g. Johnsons, (2018) inventory, my initial and final classification, whether it is an active, inactive, ice-exposed rock glacier, comments, and state name, mountain range). Because of the laborious and subjective nature of the process, two people with glaciology and remote sensing background independently checked the classifications and outlines using my classification scheme; adjustments were made if there were disagreements. 
To estimate area uncertainty of the rock glaciers, the outlines of 20 rock glaciers were digitized in three ways. The lower margin of each rock glacier was kept the same, but the upper margin was digitized differently and followed the top of the depositional zone, the rooting zone (as described previously), and halfway up the erosional zone. These different perimeters essentially accounted for all the uncertainty. The resulting root mean squared difference between the different perimeters was $\pm 7 \%$.

Once the inventory was finalized, the outlines and dots were superimposed, in ArcGIS, on a 1/3 arc-second (10 m) digital elevation model obtained from the USGS National Elevation Dataset (NED; U.S. Geological Survey, 2017). Slope, aspect, and solar radiation rasters were created for each rock glacier. For the aspect, the cosine (eastness) and sine (northness) of each cell within the rock glacier polygon were calculated. These values were then averaged and recomposed into an angle (degrees) using arctangent. Also, the mean monthly values of clear sky insolation $\left(\mathrm{WH} \mathrm{m}^{-2}\right)$ for a transparent atmosphere for the year 2020 were calculated using the ArcMap tool called Area Solar Radiation. It uses the DEM to create a fisheye view of the sky by measuring horizon angles in every direction of each cell of the DEM. It then creates a sun map showing how the sun moves through the sky at different times of the year based on latitude. The sun map is then overlain on the viewshed and the total number of hours of direct insolation is calculated for each pixel. For each rock glacier, area and minimum, maximum, and mean of elevation, slope, and solar radiation were calculated. Latitude and longitude were calculated for the centroid of each outline. For the FOI the latitude and longitude were determined and the elevation, slope, aspect, were calculated by using the 
extract values to points tool. No interpolation was used with this tool, instead, the value of the cell center was used.

To investigate the climate of rock glaciers and FOI the outlines and dots were superimposed over rasters of average monthly and annual temperature and precipitation values for the period of 1971-2010 at a cell size of $800 \mathrm{~m}$ (Daly et al., 2007). For any given rock glacier, all the values for monthly temperature or precipitation that intersect or are within the outlines were averaged. West-wide averages of air temperature for all the rock glaciers were used to define winter and summer months. Winter months were defined as those with mean monthly air temperatures below $0^{\circ} \mathrm{C}$ (November-April) and summer as the months with mean temperatures above $0^{\circ} \mathrm{C}$ (June-September). The temperature values of each rock glacier were averaged for each month and the precipitation values were totaled to calculate the seasonal temperature and precipitation values for each season. To understand if geology affects the presence of rock glaciers the State Geologic Map Compilation, an ArcGIS layer, was used to define the lithology of regions with and without rock glaciers (Horton et al., 2017). This layer combines the state geologic maps for the 48 contiguous United States and it includes attributes such as the geologic unit name, minimum and maximum age, generalized lithology (metamorphic, sedimentary, igneous), and major lithology (rock names, e.g.; granite, carbonate, diorite). The geology that intersects or is within rock glacier outlines were extracted as well as the geology that doesn't intersect or are within the outlines. This was used to compare the geology of regions with rock glaciers and those without. 
To estimate the water volume equivalent of rock glaciers, the rock glacier volume, estimated from its area and empirically-derived thickness, was multiplied by a value of ice fraction. Brenning's (2005) empirical power-law relation was used to estimate rock glacier thickness from rock glacier area:

$$
\mathrm{H}=50 \times \mathrm{S}^{0.2},
$$

where mean rock glacier thickness $\mathrm{H}(\mathrm{m})$ is calculated as a function of the planimetric area $\mathrm{S}\left(\mathrm{km}^{2}\right)$. This equation was based on morphometric field measurements on 19 rock glaciers in the Andean Mountains. This equation has been used in recent rock glacier studies (Millar and Westfall, 2019; Azócar and Brenning, 2010; Rangecroft et al., 2015; Janke, 2007; Jones et al., 2018). Estimates of volumetric ice content will be drawn from literature and the density of ice was assumed to be $900 \mathrm{~kg} \mathrm{~m}^{-3}$. 


\subsection{Results and Analysis}

\section{Inventory of Rock Glaciers}

The final inventory identified 2249 rock glaciers (1564 active, 685 inactive)

totaling $421.2 \mathrm{~km}^{2}$ across 10 states and in 55 mountain ranges. I compared the

classification scheme of my inventory against six regional inventories and one west-wide

inventory for which I had location data (Appendix B). The comparison examined whether

the same features were identified and how they were classified (Table 5-1).

Table 5-1: A comparison of the number and classification of rock glaciers between the regional inventories and this study. "Features" is the number of rock glaciers-like features identified by the regional inventories. "Rock Glaciers" is the number of features in the regional inventory that I identified as rock glaciers. "FOI" is the number of features reclassified as features of interest. "Eliminated" is the number of features eliminated from the regional inventory. "Added" is the number of rock glaciers missing from the regional inventory. "Total" is the number of rock glaciers for the region. Riffle, 2018 is located in the Cascade Range in Washington, Millar and Westfall, 2019 in the Great Basin, Johnson et al., 2007 in the Lemhi Range in Idaho, Legg, 2018 in Glacier National Park, Montana, Florentine et al., 2014 in the Beartooth and Absaroka Ranges in southern Montana/ northern Wyoming, Kinworthy, 2016 in New Mexico, and Johnson, 2018 in the western US.

Riffle

\begin{tabular}{rrrrrr} 
Features & Rock Glaciers & FOI & Eliminated & Added & Total \\
\hline 140 & 27 & 92 & 21 & 8 & 35 \\
842 & 156 & 660 & 26 & 27 & 183 \\
67 & 34 & 30 & 3 & 50 & 84 \\
27 & 7 & 19 & 1 & 0 & 7 \\
404 & 174 & 205 & 25 & 61 & 235 \\
426 & 24 & 90 & 312 & 14 & 38 \\
10046 & 2090 & 7169 & 787 & 159 & 2249
\end{tabular}


My combined inventories of rock glaciers and FOI largely agrees (85\%-96\%) with the regional rock glacier inventories. That is, we agree that the feature probably contains ice. The exemption is Kinworthy's (2016) inventory of New Mexico, of which $27 \%$ did not meet any of my criteria of a rock glacier or FOI. But what I identified as a rock glacier was much more limited than those of the regional inventories and therefore I classified fewer features as rock glaciers and most were considered features of interest. The main reason for this difference is my criterion that rock glaciers have to extend into the valley, which is an indicator of significant movement and is not included in the other inventories (Figure 5-1).
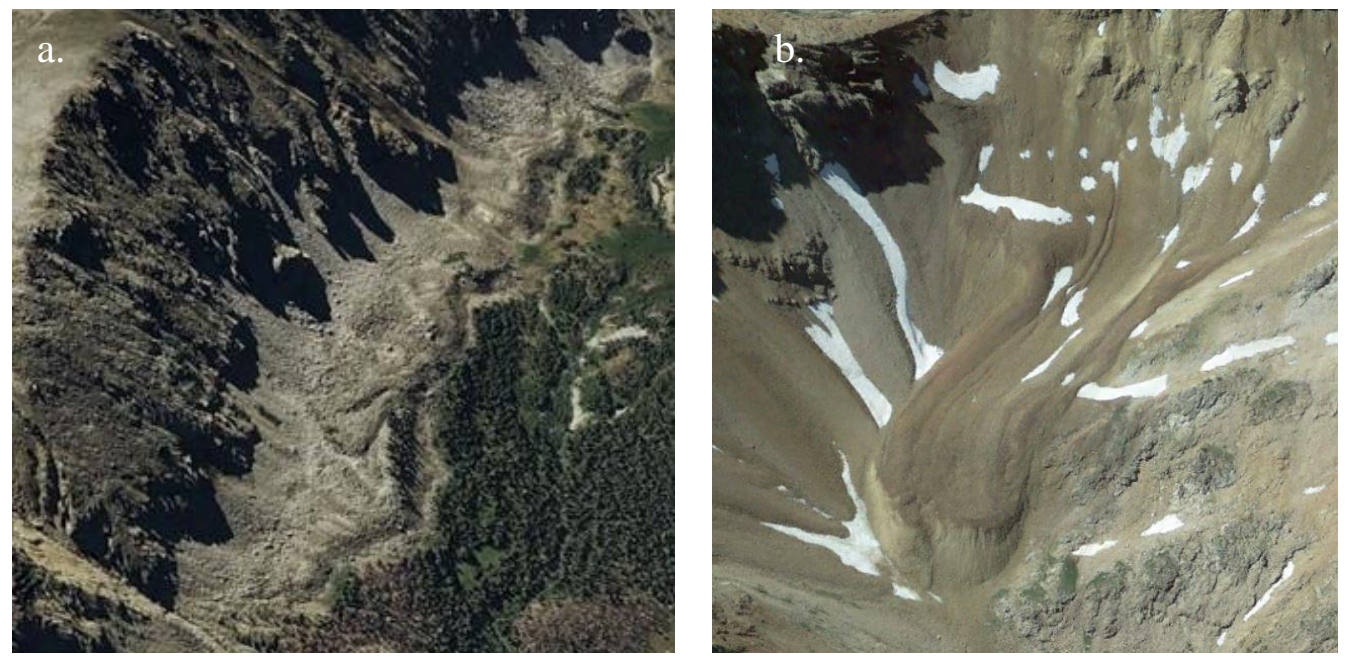

Figure 5-1: Examples of features that a) do not extend into the valley (Beartooth- Absaroka Range, Montana, $45.13638^{\circ},-109.4715^{\circ}$ ) and b) does extend into the valley (Boise-Sawtooth-Pioneer Ranges, Idaho, $43.9051^{\circ}$, $\left.114.4916^{\circ}\right)$. Image source: Google Earth Pro.

Several inventories subclassified their rock glaciers into active, inactive, and relict categories (Riffle, 2018; Millar and Westfall, 2019; Legg, 2016). Half of their active rock glaciers match my classification of a rock glacier (both active and inactive), 44\% - 48\%, however, most in the inactive and relict categories were re-classified as FOI (Table 5-2). 
We agree that the features are no longer moving but disagree on whether they are rock glaciers.

Table 5-2: Comparison between subclassification of the regional inventories and my study. Sum is the sum of Active and Inactive.

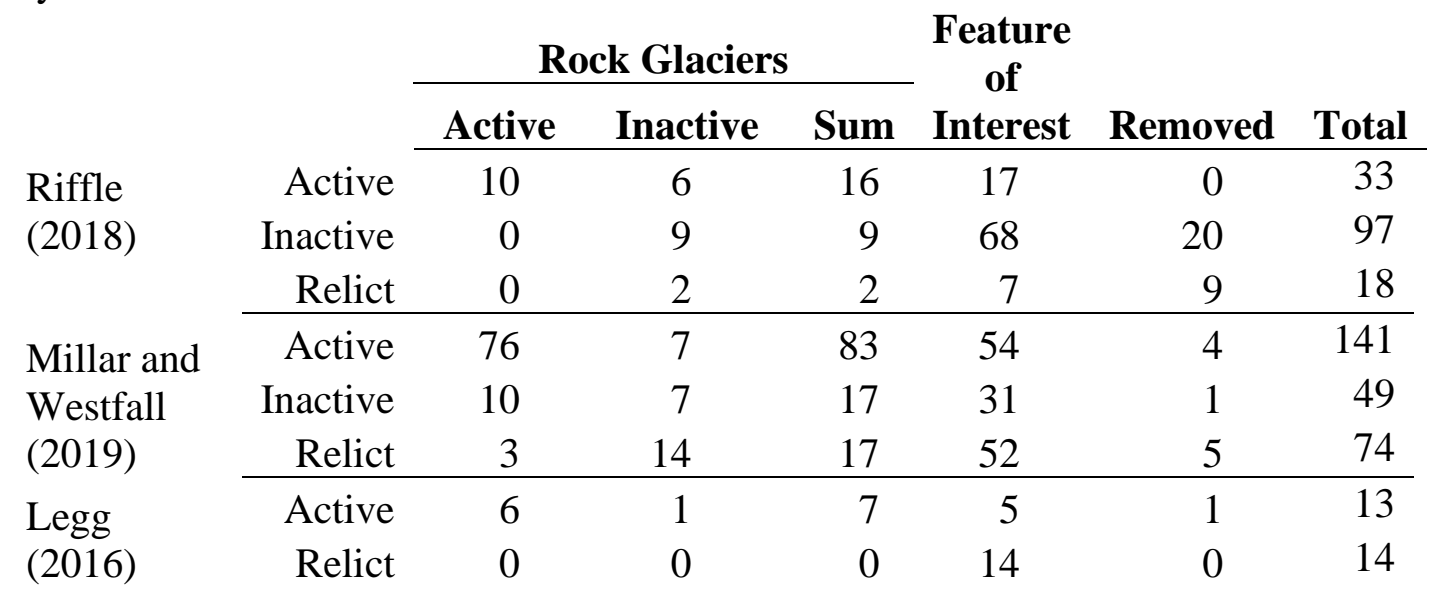

\section{Topographic Characteristics}

Colorado has the largest number of rock glaciers, totaling $936\left(159.3 \mathrm{~km}^{2}\right)$ and as many as Idaho, Montana, and California combined (Figure 5-2; Table 5-3). Active rock glaciers range in area from $0.015 \mathrm{~km}^{2}$ (San Juan Mts. CO) to $2.39 \mathrm{~km}^{2}$ (Sulfur Creek Rock Glacier, Beartooth-Absaroka Range, WY) with a mean area of $0.18 \mathrm{~km}^{2}$ (standard deviation 0.19). Inactive rock glaciers ranged in area from $0.009 \mathrm{~km}^{2}$ (Front Range, CO) to $1.82 \mathrm{~km}^{2}$ (Elk-West Elk Mts. CO) with a mean area of $0.20 \mathrm{~km}^{2}(0.20)$. The mean elevation of individual rock glaciers ranged from $1670 \mathrm{~m}$ in the northern Cascade Range, Washington, to $4093 \mathrm{~m}$ in the Sawatch Range, Colorado (Table 5-4). Mean (standard deviation) elevation of active and inactive rock glaciers are $3384 \mathrm{~m}$ (382) and $3072 \mathrm{~m}$ (462) respectively. 


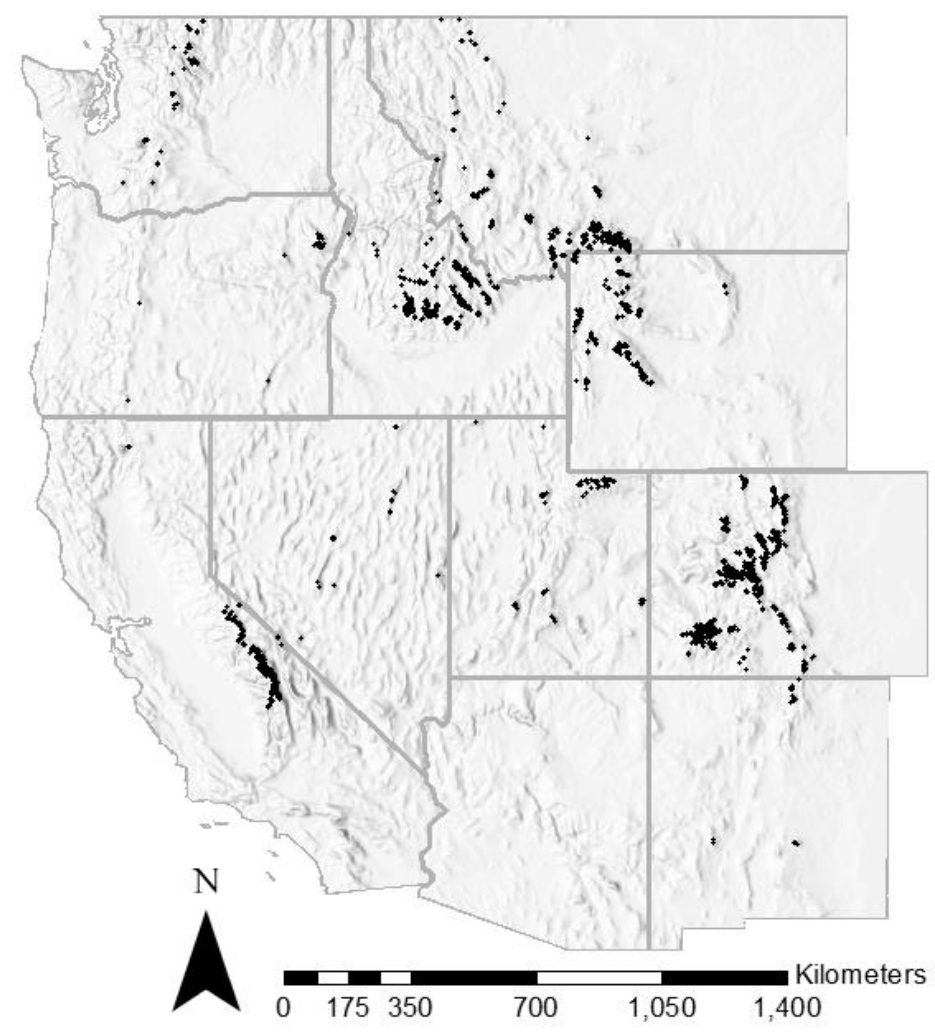

Figure 5-2: The distribution of rock glaciers across the western United States.

Table 5-3: The area of active and inactive (in parenthesis) rock glaciers in each state.

\begin{tabular}{lrrllllrr} 
State & \multicolumn{2}{c}{ Number } & \multicolumn{2}{c}{ Mean $\left(\mathrm{km}^{2}\right)$} & \multicolumn{2}{c}{ Median $\left(\mathrm{km}^{2}\right)$} & \multicolumn{2}{c}{ Total $\left(\mathrm{km}^{2}\right)$} \\
\hline WA & 15 & $(23)$ & 0.15 & $(0.20)$ & 0.17 & $(0.16)$ & 2.22 & $(4.50)$ \\
OR & 11 & $(9)$ & 0.11 & $(0.09)$ & 0.08 & $(0.09)$ & 1.16 & $(0.84)$ \\
CA & 235 & $(27)$ & 0.23 & $(0.28)$ & 0.18 & $(0.23)$ & 54.26 & $(7.64)$ \\
ID & 208 & $(143)$ & 0.14 & $(0.15)$ & 0.10 & $(0.12)$ & 29.16 & $(21.09)$ \\
NV & 2 & $(11)$ & 0.23 & $(0.20)$ & 0.23 & $(0.09)$ & 0.47 & $(2.22)$ \\
MT & 200 & $(124)$ & 0.25 & $(0.24)$ & 0.16 & $(0.18)$ & 50.02 & $(29.99)$ \\
WY & 153 & $(26)$ & 0.25 & $(0.25)$ & 0.18 & $(0.24)$ & 38.48 & $(6.61)$ \\
UT & 34 & $(39)$ & 0.13 & $(0.15)$ & 0.11 & $(0.10)$ & 4.52 & $(5.94)$ \\
CO & 698 & $(265)$ & 0.15 & $(0.21)$ & 0.11 & $(0.13)$ & 103.95 & $(55.30)$ \\
NM & 8 & $(18)$ & 0.10 & $(0.11)$ & 0.04 & $(0.11)$ & 0.82 & $(2.02)$ \\
\hline Total & 1564 & $(685)$ & 0.18 & $(0.20)$ & 0.12 & $(0.14)$ & 285.06 & $(136.14)$
\end{tabular}


Table 5-4: The elevation of active and inactive (in parenthesis) rock glaciers in each state. Max is the maximum, and Min is the minimum.

\begin{tabular}{lrrrlllll} 
State & \multicolumn{2}{c}{ Number } & \multicolumn{2}{c}{ Max $(\mathrm{m})$} & \multicolumn{2}{c}{ Min $(\mathrm{m})$} & \multicolumn{2}{c}{ Mean $(\mathrm{m})$} \\
\hline WA & 15 & $(23)$ & 2600 & $(2571)$ & 1736 & $(1618)$ & 2154 & $(2030)$ \\
OR & 11 & $(9)$ & 2834 & $(2701)$ & 2360 & $(2185)$ & 2606 & $(2413)$ \\
CA & 235 & $(27)$ & 4116 & $(3474)$ & 2884 & $(2258)$ & 3541 & $(3121)$ \\
ID & 208 & $(143)$ & 3351 & $(3415)$ & 2495 & $(2198)$ & 2954 & $(2739)$ \\
NV & 2 & $(11)$ & 3507 & $(3285)$ & 3162 & $(2082)$ & 3293 & $(2896)$ \\
MT & 200 & $(124)$ & 3701 & $(3254)$ & 1974 & $(1926)$ & 2907 & $(2746)$ \\
WY & 153 & $(26)$ & 3898 & $(3555)$ & 2627 & $(2527)$ & 3210 & $(2970)$ \\
UT & 34 & $(39)$ & 3768 & $(3586)$ & 2954 & $(2682)$ & 3358 & $(3216)$ \\
CO & 698 & $(265)$ & 4152 & $(4079)$ & 3117 & $(2299)$ & 3674 & $(3524)$ \\
NM & 8 & $(18)$ & 3782 & $(3675)$ & 3316 & $(2348)$ & 3571 & $(2878)$ \\
\hline Total & 1564 & $(685)$ & 4152 & $(4079)$ & 1736 & $(1618)$ & 3385 & $(3072)$
\end{tabular}

The mean area for all rock glaciers is $0.18 \mathrm{~km}^{2}$ with a median of $0.12 \mathrm{~km}^{2}$. For active rock glacier the mean (median) area is smaller, $0.18 \mathrm{~km}^{2}\left(0.12 \mathrm{~km}^{2}\right)$, than inactive rock glaciers, $0.2 \mathrm{~km}^{2}\left(0.14 \mathrm{~km}^{2}\right.$; Figure 5-3). Their frequency distribution is skewed towards small areas, and the most frequent areas are also the smallest. The mean and median elevations are $3289 \mathrm{~m}$ and $3396 \mathrm{~m}$. The mean (median) elevations for active rock glaciers are higher, $3385 \mathrm{~m}(3499 \mathrm{~m})$, than inactive rock glaciers, $3073 \mathrm{~m}(3064 \mathrm{~m})$. The mean elevations are bimodally distributed with peaks at $3605 \mathrm{~m}$ and $2863 \mathrm{~m}$ (Figure 5-3, D-4). The local minimum in the elevation histogram (Figure 5-3a) between high and low elevations are different for active $(\sim 3300 \mathrm{~m})$ and inactive $(\sim 3100 \mathrm{~m})$ rock glaciers. The low elevation $(<3245 \mathrm{~m})$ rock glaciers $(42 \%)$ are mainly found in the Pacific Northwest region (Washington, Oregon, Idaho, western Montana). Most high elevation $(>=3245 \mathrm{~m})$ rock glaciers are found in Colorado and California. Elevations for inactive rock glaciers are lower than active ones and statistically different. Most rock glaciers (76\%) face northward (NW-N-NE) and have lower elevations (3252 m) than those that face other 
directions (3407 m). Rock glacier slopes are normally distributed and largely range between $10^{\circ}$ and $25^{\circ}$ with a median of $16^{\circ}$, active ones have statistically steeper slopes (median $17.5^{\circ}$ ) than inactive ones (median $15.5^{\circ}$ ). Bedrock geology does not influence rock glacier occurrence or distribution at the mountain range or west-wide scale. (Figure D-4).
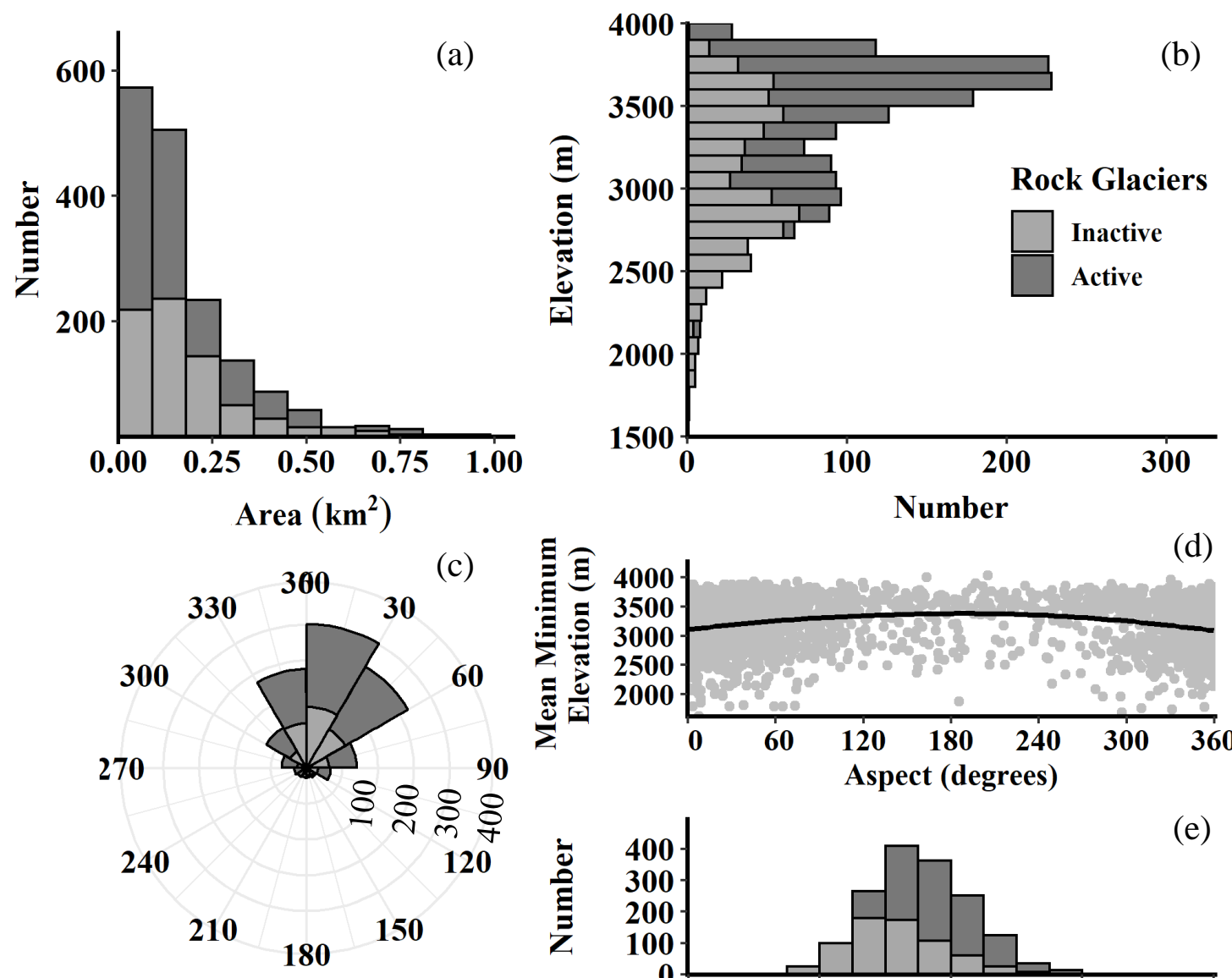

Aspect (degrees)

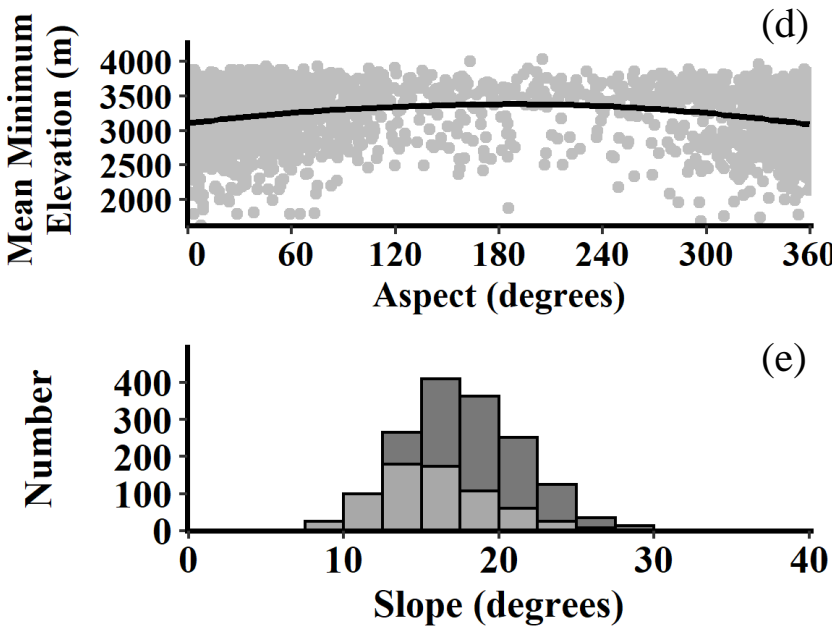

Figure 5-3: Overlapping histograms with the topographic characteristics of active and inactive rock glaciers for area (a), elevation (b), aspect (c), aspect and minimum elevation (d), and slope (e). Each interval is denoted by the highest value in each interval. Area is in intervals of $0.09 \mathrm{~km}^{2}$. Elevation is in intervals of $100 \mathrm{~m}$. Aspect is in intervals of $30^{\circ}$. Slope is in intervals of $2.5^{\circ}$. 
Table 5-5: Mean and standard deviation (Std Dev) of topographical characteristics of active and inactive rock glaciers. Bold represent characteristics that are statistically significant (t-test, p-value $<0.05$ ).

\begin{tabular}{lrrrr} 
& \multicolumn{2}{c}{ Active } & \multicolumn{2}{c}{ Inactive } \\
& Mean & Std Dev & Mean & Std Dev \\
\cline { 2 - 5 } Elevation $(\mathrm{m})$ & $\mathbf{3 3 8 5}$ & 382 & $\mathbf{3 0 7 3}$ & 462 \\
Slope (degrees) & $\mathbf{1 8}$ & 4 & $\mathbf{1 6}$ & 4 \\
Area $\left(\mathrm{km}^{2}\right)$ & 0.18 & 0.19 & 0.2 & 0.2
\end{tabular}

The mean elevation of rock glaciers (active and inactive) increases to the south and east from Washington to Colorado (Figure D-2). From north to south, Washington to California (longitude band $-122^{\circ} \mathrm{W}--117^{\circ} \mathrm{W}$ ) the mean elevation increases at a rate of $+1.17 \mathrm{~m} \mathrm{~km}^{-1}$, the rate decreases further inland (western Montana to New Mexico, $\left.112^{\circ} \mathrm{W}--100^{\circ} \mathrm{W}\right)+0.92 \mathrm{~m} \mathrm{~km}^{-1}$ (Figure 5-4). The west to east trends in elevation decreases in rate further south from $+0.14 \mathrm{~m} \mathrm{~km}^{-1}$ (northern Washington to Montana, latitude band $47^{\circ}-49^{\circ}$ ), to $+0.08 \mathrm{~m} \mathrm{~km}^{-1}$ (California to Colorado, latitude band $35^{\circ}-44^{\circ}$ ) All the trends (active and inactive) are statistically significant (t-test, p-value $<0.05$ ) except the west to east trend from northern Washington to Montana. 

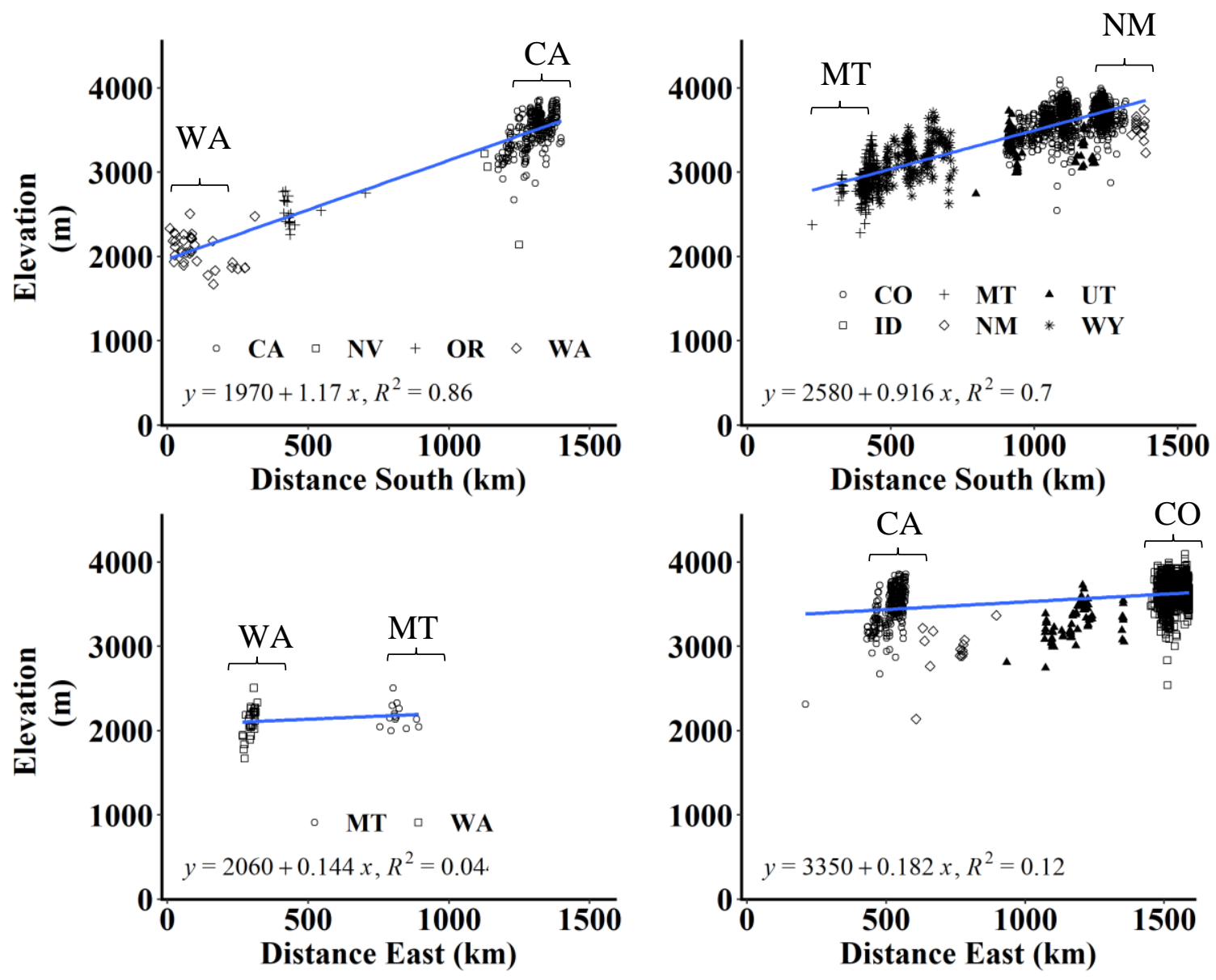

Figure 5-4: Elevation trends of rock glaciers along two north south transects (top) and two east-west transects (bottom).

\section{Climate}

Rock glaciers are found in regions at a mean summer air temperature of $8^{\circ} \mathrm{C}$ (range $\left.3-16^{\circ} \mathrm{C}\right)$, mean winter temperatures of $-6^{\circ} \mathrm{C}\left(-15-0^{\circ} \mathrm{C}\right)$, and mean winter precipitation of $691 \mathrm{~mm}$ (130 - $3700 \mathrm{~mm}$; Figure 5-5). Active rock glaciers occur at statistically significant cooler temperatures (both seasonal and annual) and more winter precipitation than inactive rock glaciers (Table 5-6; Figure E-4). Neither summer precipitation nor solar insolation is significantly different between active and inactive 
rock glaciers. (Figure 5-6). Elevation is higher for active compared to inactive rock glaciers (statistically significant) which account for their lower air temperatures.
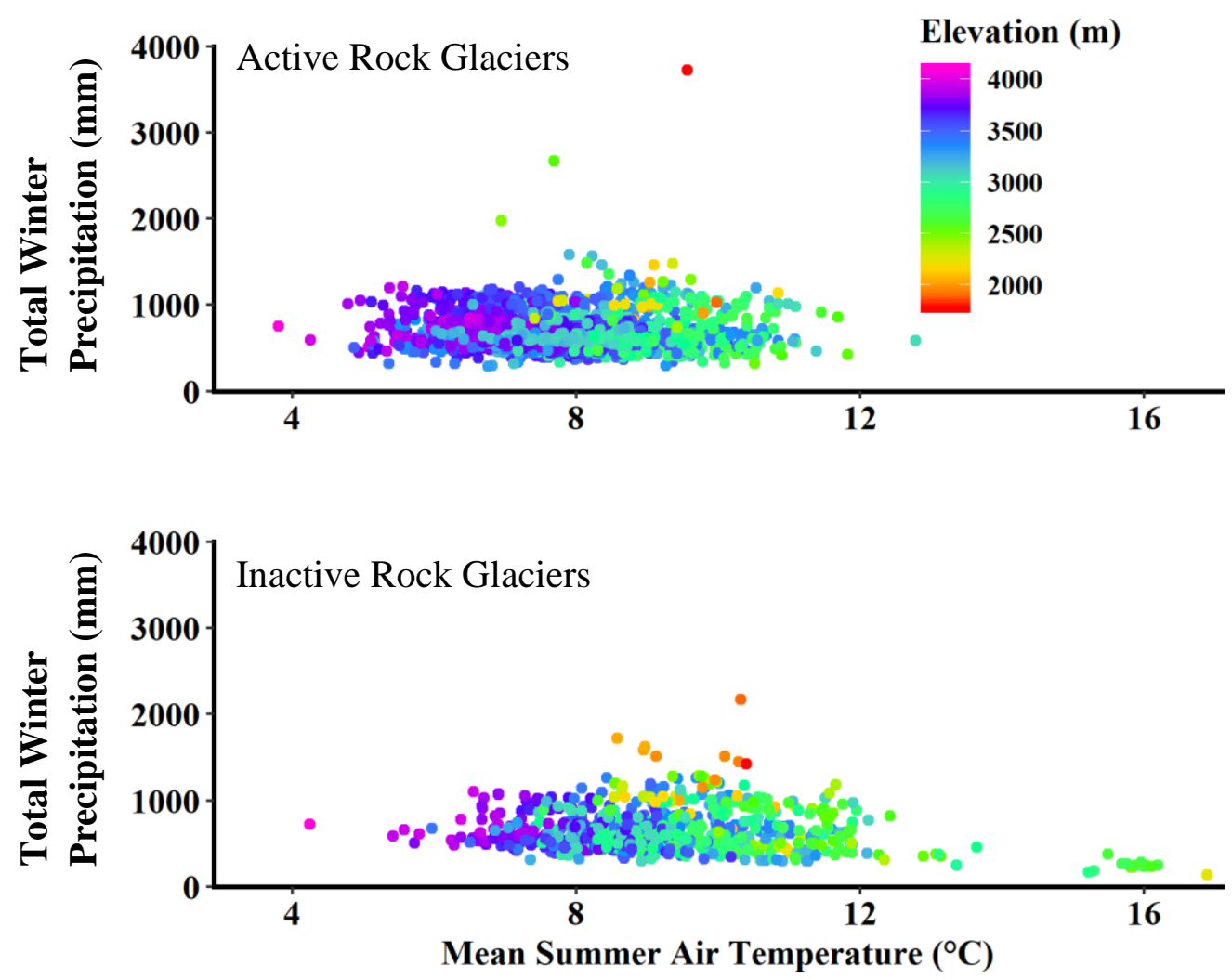

Figure 5-5: Total winter precipitation and summer temperature for active (top) and inactive (bottom) rock glaciers in the western US. Rock glaciers with winter precipitation greater than $1500 \mathrm{~mm}$ are in and around the Cascade mountains of Washington, and ones with summer air temperatures greater than $15^{\circ} \mathrm{C}$ are in New Mexico. 
Table 5-6: Mean and standard deviation (Std Dev) of climate characteristics of active and inactive rock glaciers. Bold represent statistically significant values (t-test, $\mathrm{p}$-value < 0.05). Temp is temperature in ${ }^{\circ} \mathrm{C}$ and Precip is precipitation in $\mathrm{mm}$.

Active Inactive

\begin{tabular}{|c|c|c|c|c|}
\hline & & \\
\hline & Mean & Std Dev & Mean & Std Dev \\
\hline Summer Air Temp & 7.8 & 1.2 & 9.3 & 1.7 \\
\hline Summer Precip & 238 & 84 & 242 & 67 \\
\hline Winter Air Temp & -7.0 & 1.4 & -6.0 & 1.9 \\
\hline Winter Precip & 708 & 233 & 655 & 249 \\
\hline Annual Air Temp & -0.7 & 1.2 & 0.5 & 1.8 \\
\hline Annual Precip & 1115 & 259 & 1068 & 288 \\
\hline Insolation $\left(\mathrm{WH} \mathrm{m}^{-2}\right)$ & 1474120 & 621894 & 1448413 & 621894 \\
\hline Elevation (m) & 3385 & 382 & 3073 & 462 \\
\hline
\end{tabular}
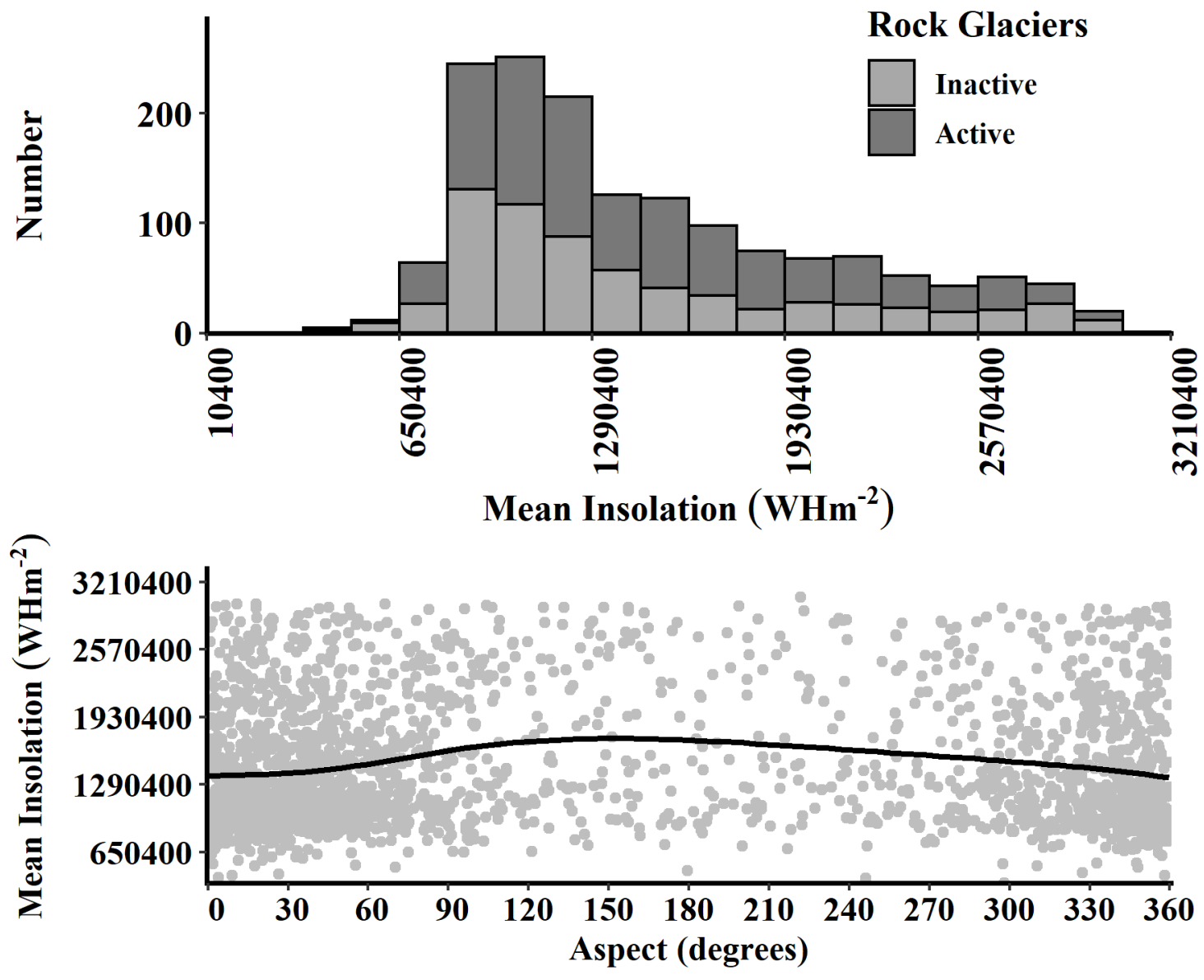

Figure 5-6: Overlapping histogram of the mean insolation of active and inactive rock glaciers (top). Each interval is denoted by the highest value in each interval, with intervals of $160000 \mathrm{WHm}^{-2}$. Grey dots represent rock glaciers (active and inactive) and line is a fourth order polynomial regression of mean insolation and aspect (bottom). 
Separating the data by mountain range better illuminates the climatic environment of rock glaciers. Examining the rock glaciers in different mountain ranges in Colorado, for example, higher elevations have colder air temperatures, and greater precipitation (Figure 5-7). By comparison, inactive rock glaciers have warmer mean summer air temperatures and similar precipitation. The ranges with high winter precipitation are located in the western part of the state compared to the ranges with low precipitation.
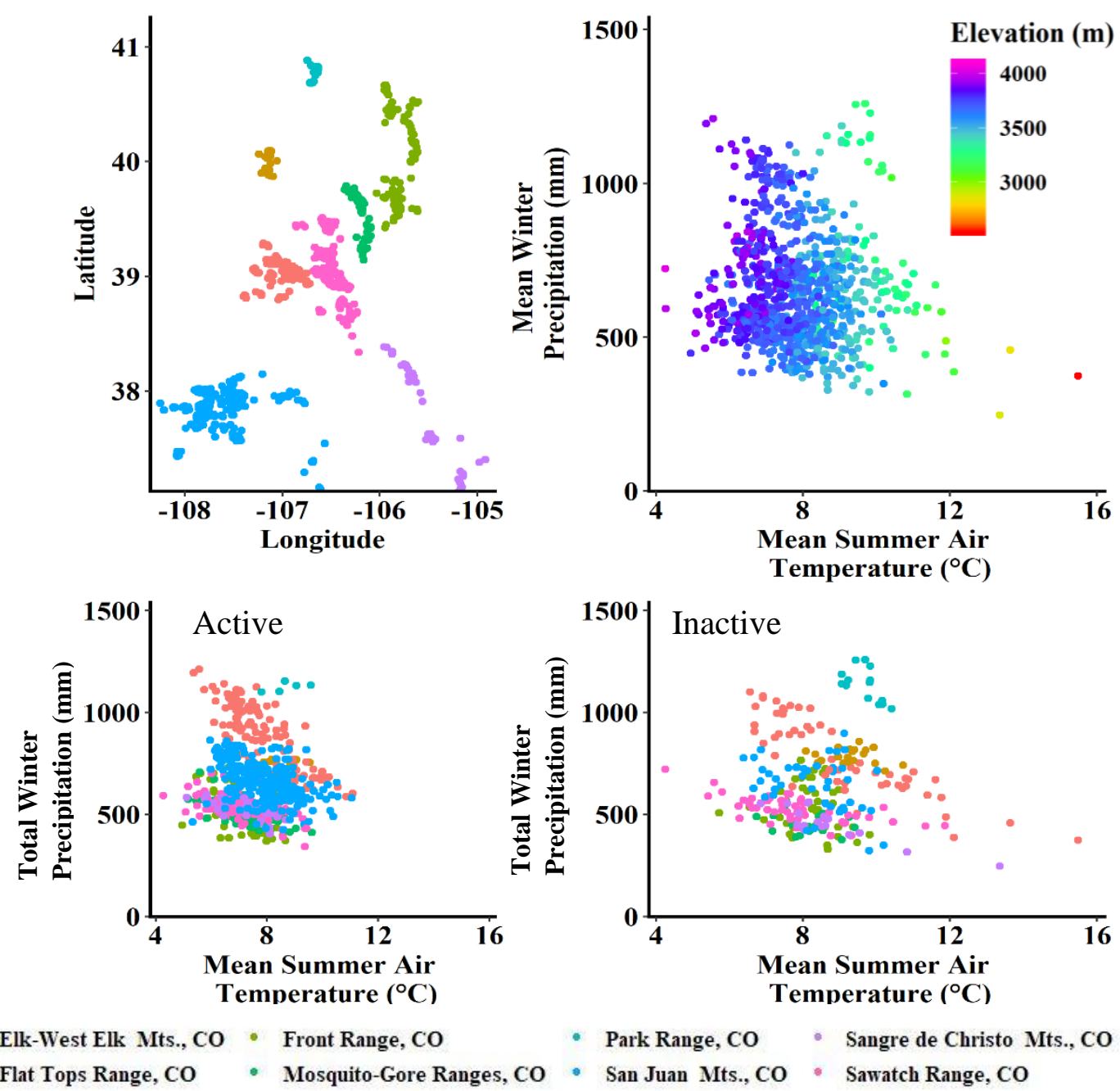

$\begin{array}{ll}\text { Elk-West Elk Mts., CO } & \text { - Front Range, CO } \\ \text { - Flat Tops Range, CO } & \text { Mosquito-Gore Ranges, CO }\end{array}$

Figure 5-7: Climatic trends of rock glaciers in Colorado, including their latitude and longitudinal positions (top left), the relationship with mean elevation (top right), and the relationship with mountain ranges for active and inactive. 
The north-south rate of change in total winter precipitation along the western transect of Washington to California (longitude band $-122^{\circ}-117^{\circ}$ ) is $-0.208 \mathrm{~mm} \mathrm{~km}^{-1}$ (Figure 5-8); for mean summer air temperature $-0.001{ }^{\circ} \mathrm{C} \mathrm{km}^{-1}$. Further inland, (western Montana to New Mexico (longitude band $-112^{\circ}-100^{\circ}$ ) the rate of change was less for both winter precipitation $-0.030 \mathrm{~mm} \mathrm{~km}^{-1}$ and mean summer air temperature $-0.0002{ }^{\circ} \mathrm{C}$ $\mathrm{km}^{-1}$. For active (inactive) rock glaciers (not shown), the trends of precipitation and temperature along the western transect are $-0.17 \mathrm{~mm} \mathrm{~km}^{-1}\left(-0.36 \mathrm{~mm} \mathrm{~km}^{-1}\right)$, and -0.001 ${ }^{\circ} \mathrm{C} \mathrm{km}^{-1}\left(+0.0005{ }^{\circ} \mathrm{C} \mathrm{km}^{-1}\right)$, respectively. Further inland, the trend was less for both precipitation, $-0.01 \mathrm{~mm} \mathrm{~km}^{-1}\left(-0.002 \mathrm{~mm} \mathrm{~km}^{-1}\right)$, and temperature, $-0.0002{ }^{\circ} \mathrm{C} \mathrm{km}^{-1}(-$ $\left.0.0003{ }^{\circ} \mathrm{C} \mathrm{km}^{-1}\right)$. The inland trends for summer air temperature and winter precipitation of active rock glaciers are statistically significant (t-test, $\mathrm{p}$-value $<0.05$ ) for western Montana to New Mexico. For inactive rock glaciers, all the trends are significant except for the summer temperature for Washington to California. 

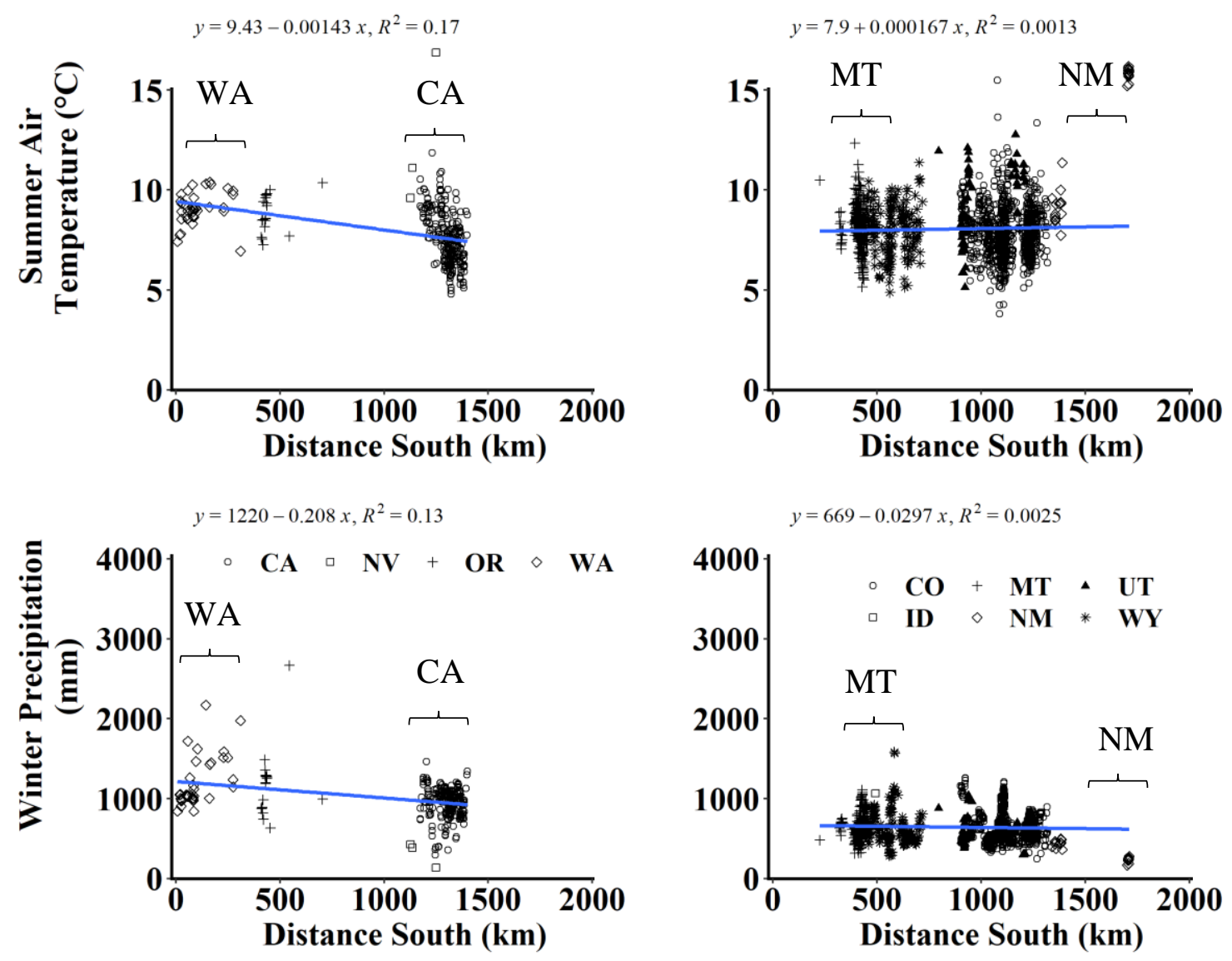

Figure 5-8: Climatic trends of rock glaciers along two north south transects; Washington through California (left) and Montana through New Mexico (right).

The rate of change of total winter precipitation along a northern west-east, Washington to Montana (latitude band $47^{\circ}-49^{\circ}$ ), is $-0.472 \mathrm{~mm} \mathrm{~km}{ }^{-1}$; mean summer air temperature increases at a rate of $+0.001{ }^{\circ} \mathrm{C} \mathrm{km}^{-1}$ (Figure 5-10). Further south (California to Colorado, latitude band $35^{\circ}-44^{\circ}$ ), precipitation rate of change along a west to east transect less in the north, $-0.287 \mathrm{~mm} \mathrm{~km}^{-1}$, while the temperature has no trend, $0{ }^{\circ} \mathrm{C} \mathrm{km}^{-1}$. For active (inactive) rock glaciers (not shown), the trends of precipitation and temperature along the northern transect are $+0.06 \mathrm{~mm} \mathrm{~km}^{-1}\left(-0.96 \mathrm{~mm} \mathrm{~km}^{-1}\right)$ and +0.0005 ${ }^{\circ} \mathrm{C} \mathrm{km}^{-1}\left(+0.002{ }^{\circ} \mathrm{C} \mathrm{km}^{-1}\right)$, respectively. Further south, the precipitation trend is lower 
than the north, $-0.3 \mathrm{~mm} \mathrm{~km}^{-1}\left(-0.12 \mathrm{~mm} \mathrm{~km}^{-1}\right)$, while the temperature increases at $+0.0002{ }^{\circ} \mathrm{C} \mathrm{km}^{-1}\left(-0.002{ }^{\circ} \mathrm{C} \mathrm{km}^{-1}\right)$. For active rock glaciers, the only statistically significant (t-test, $\mathrm{p}$-value $<0.05)$ trend is the winter precipitation for California to Colorado. All the trends for inactive rock glaciers are significant.
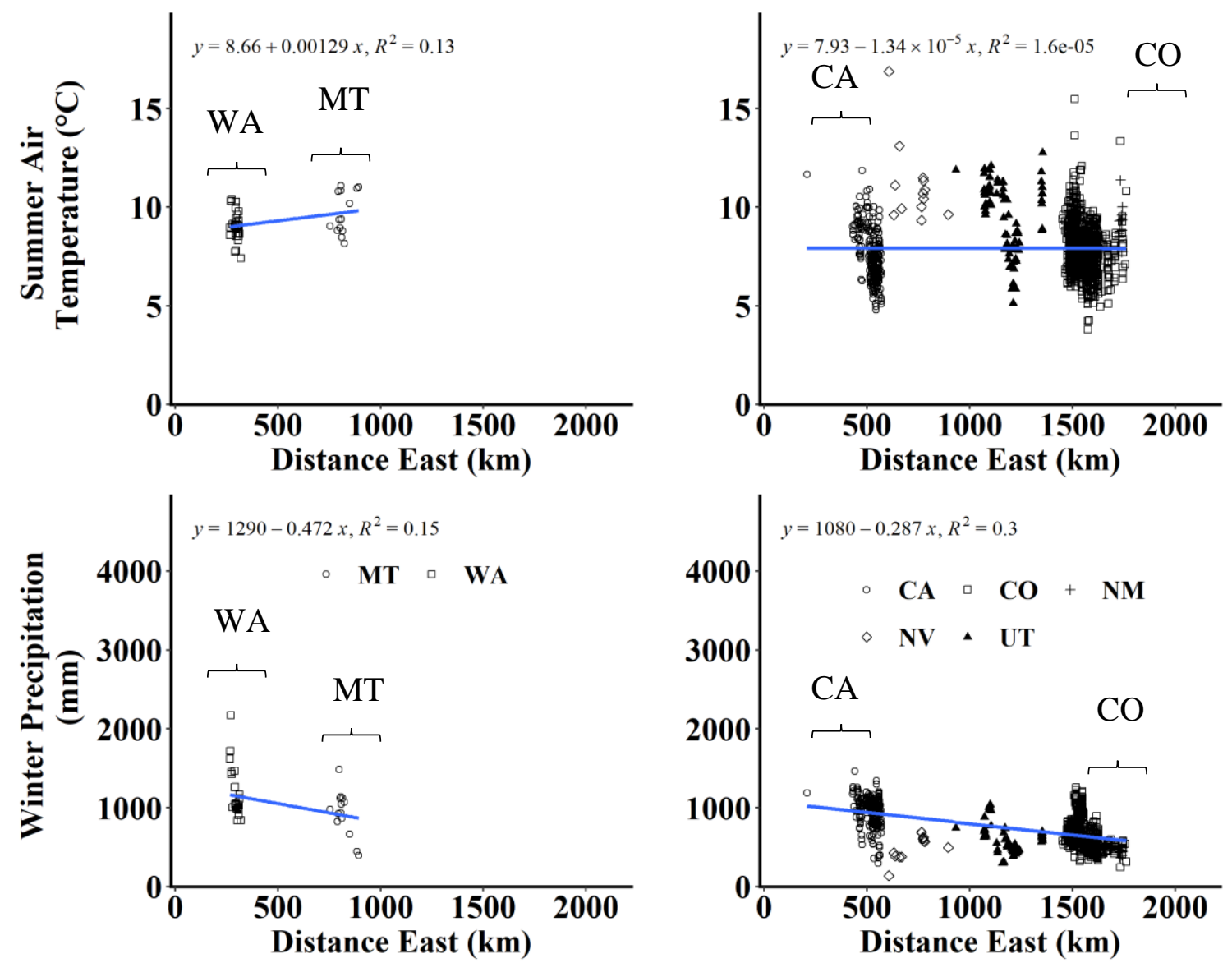

Figure 5-9: Climatic trends of rock glaciers along two east west transects; Washington through Montana (left) and California though Colorado (right).

The ice content of rock glaciers varies significantly with depth and spatial location. For active rock glaciers, the mean bulk ice fraction varies from $50-55.7 \%$ and inactive rock glaciers 17.5-22.5\% (Table 5-7). Using Brenning's (2005) empirical model (1) and assuming ice content of $53.5 \% \pm 2.2 \%$ for active and $20 \% \pm 2.5 \%$ for inactive, 
derived from Table 5-7, the total ice volume (water volume) is about $6.99 \pm 0.278 \mathrm{~km}^{3}$ $\left(6.29 \pm 0.25 \mathrm{~km}^{3}\right)($ Table $5-8)$. The uncertainty for active rock glaciers was found by taking the standard deviation of the mean active values and the uncertainty for inactive was found by taking the difference of the end values of the range of the mean inactive values. Total uncertainty was calculated from the root mean square of the uncertainty values of the active and inactive rock glaciers.

Table 5-7: Whole-rock glacier ice contents. Range (\%) represents different rock glaciers. Mean (\%) is the mean of the ranges in Range (\%). Technique is how the ice content is found. GPR is ground penetrating radar, $\mathrm{BH}$ is borehole, $\mathrm{SR}$ is seismic refraction, $\mathrm{G}$ is gravimetry, GE is geoelectric.

\begin{tabular}{ccccc} 
& Range $(\%)$ & Mean $(\%)$ & Classification & Technique \\
\cline { 2 - 5 } Arenson, 2002 & $40-70$ & 55 & Active & BH
\end{tabular}

Croce and Milana, 2002

Hausman et al., 2007

$--$

55.7

Active

$\mathrm{SR}, \mathrm{GE}$

Hausman et al, 2012

$45-60 \quad 52.5$

$40-60$

50

Monnier and Kinnard, 2015

$22-83$

52.5

25-85

55

Active GPR, SR, G

Janke et al., 2015

$10-25$

17.5

Active

GPR, SR, G

Janke et al., 2015

15-30

22.5

Active

GPR

Monnier and Kinnard, 2013

$$
\text { 15-30 }
$$

Active

$\mathrm{BH}$

Inactive

$\mathrm{BH}$

Table 5-8: Summary of rock glacier ice volume in each state. Number is the number of rock glaciers in each state.

\begin{tabular}{lrrc} 
State & Number & \multicolumn{1}{c}{ Mean $\left(\mathrm{km}^{3}\right)$} & Total $\left(\mathrm{km}^{3}\right)$ \\
\hline WA & 38 & $0.004 \pm 0.0002$ & $0.08 \pm 0.005$ \\
OR & 20 & $0.03 \pm 0.0001$ & $0.03 \pm 0.001$ \\
CA & 262 & $0.007 \pm 0.0004$ & $1.23 \pm 0.049$ \\
ID & 351 & $0.004 \pm 0.0002$ & $0.72 \pm 0.030$ \\
NV & 13 & $0.006 \pm 0.0003$ & $0.03 \pm 0.002$ \\
MT & 324 & $0.006 \pm 0.0003$ & $1.37 \pm 0.055$ \\
WY & 179 & $0.008 \pm 0.0003$ & $0.90 \pm 0.035$ \\
UT & 73 & $0.004 \pm 0.0002$ & $0.13 \pm 0.006$ \\
CO & 963 & $0.005 \pm 0.0002$ & $2.49 \pm 0.101$ \\
NM & 26 & $0.003 \pm 0.0001$ & $0.03 \pm 0.002$ \\
\hline Total & 2249 & $0.005 \pm 0.0002$ & $6.99 \pm 0.278$
\end{tabular}




\section{Comparison with Alpine glaciers}

About 1276 alpine glaciers exist in the western US, totaling $554.2 \mathrm{~km}^{2}(12.37$ $\mathrm{km}^{3}$, Fountain et al., 2017). Mountain ranges with many alpine glaciers have fewer rock glaciers, and vice versa (Figure 5-10). Like rock glaciers, alpine glaciers in the western US also exhibit a bimodal elevation distribution, but with lower elevations, peaking at $3530 \mathrm{~m}$ and $2108 \mathrm{~m}$, compared to rock glaciers 3605m and 2863m (Figure 5-11). This bimodal distribution is caused by different regional climates, the lower elevation glaciers of the Pacific Northwest result from the maritime climate of the region, compared to the warmer and drier continental climates elsewhere (Fountain et al., 2017). Both alpine and rock glaciers face northerly directions. Alpine glaciers have statistically significant lower elevations, larger areas, and steeper slopes than rock glaciers (Table 5-9). 


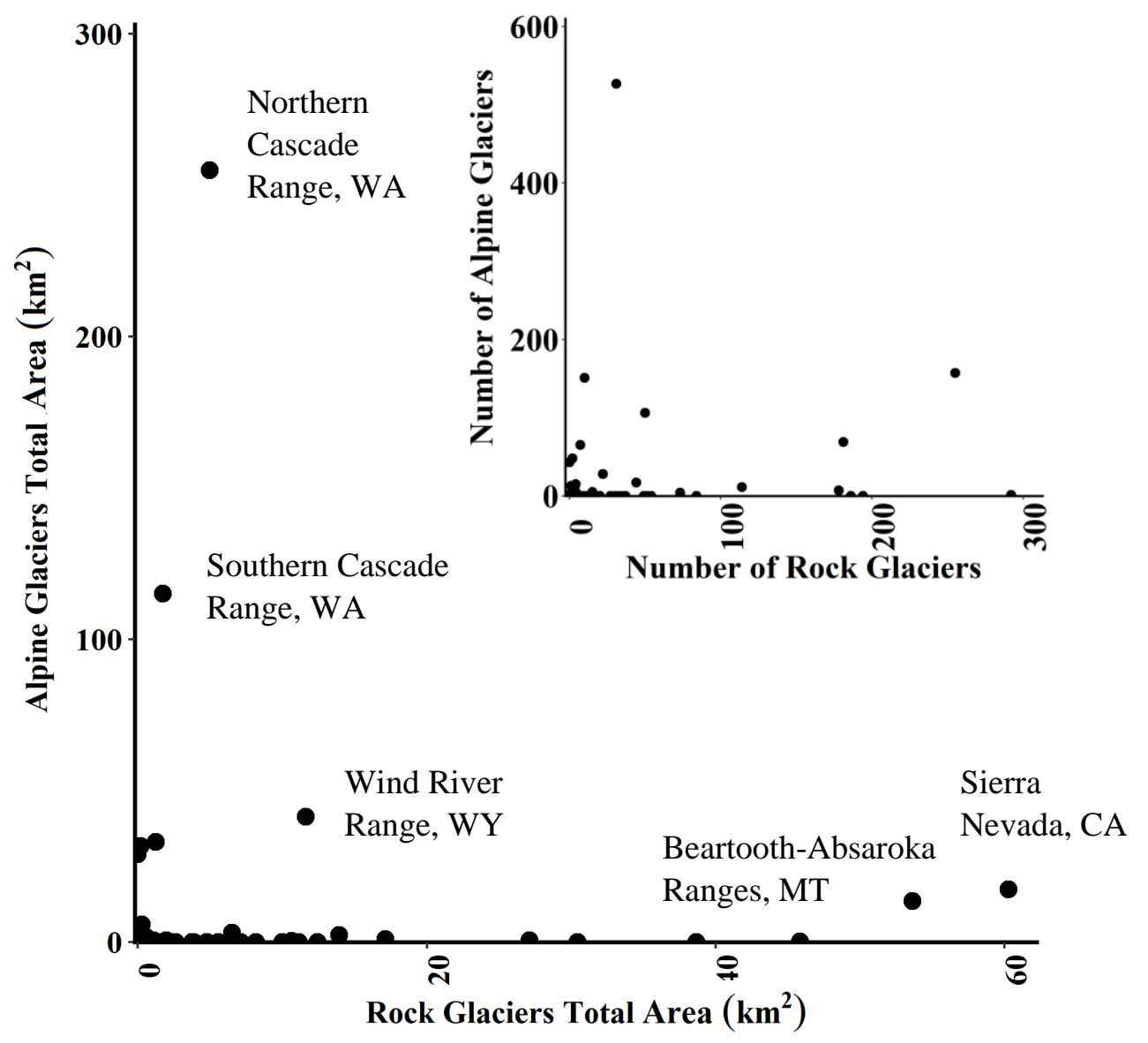

Figure 5-10: Total area and number of rock glaciers and alpine glaciers in each mountain range.

Table 5-9: Mean and standard deviation (Std Dev), of topographic characteristics of alpine glaciers and active and inactive rock glaciers. Bold represent values that are statistically different from alpine glaciers ( $\mathrm{t}$-test, $\mathrm{p}$-value $<0.05$ ).

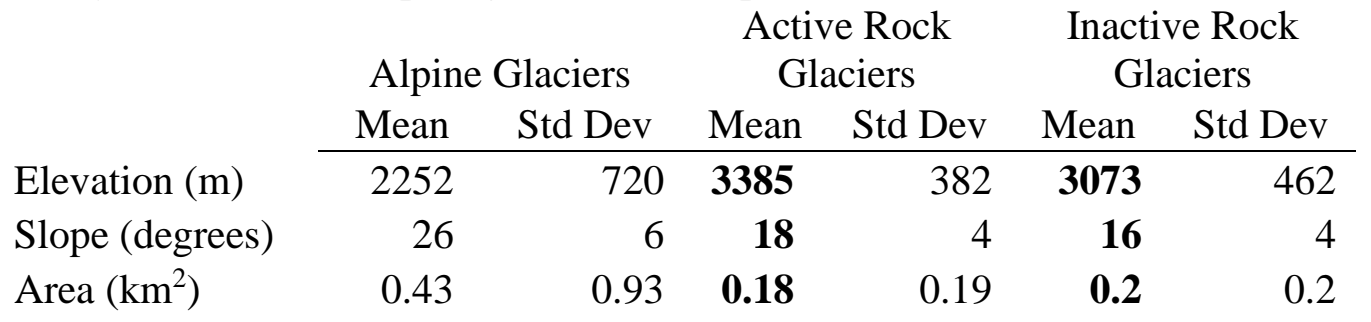



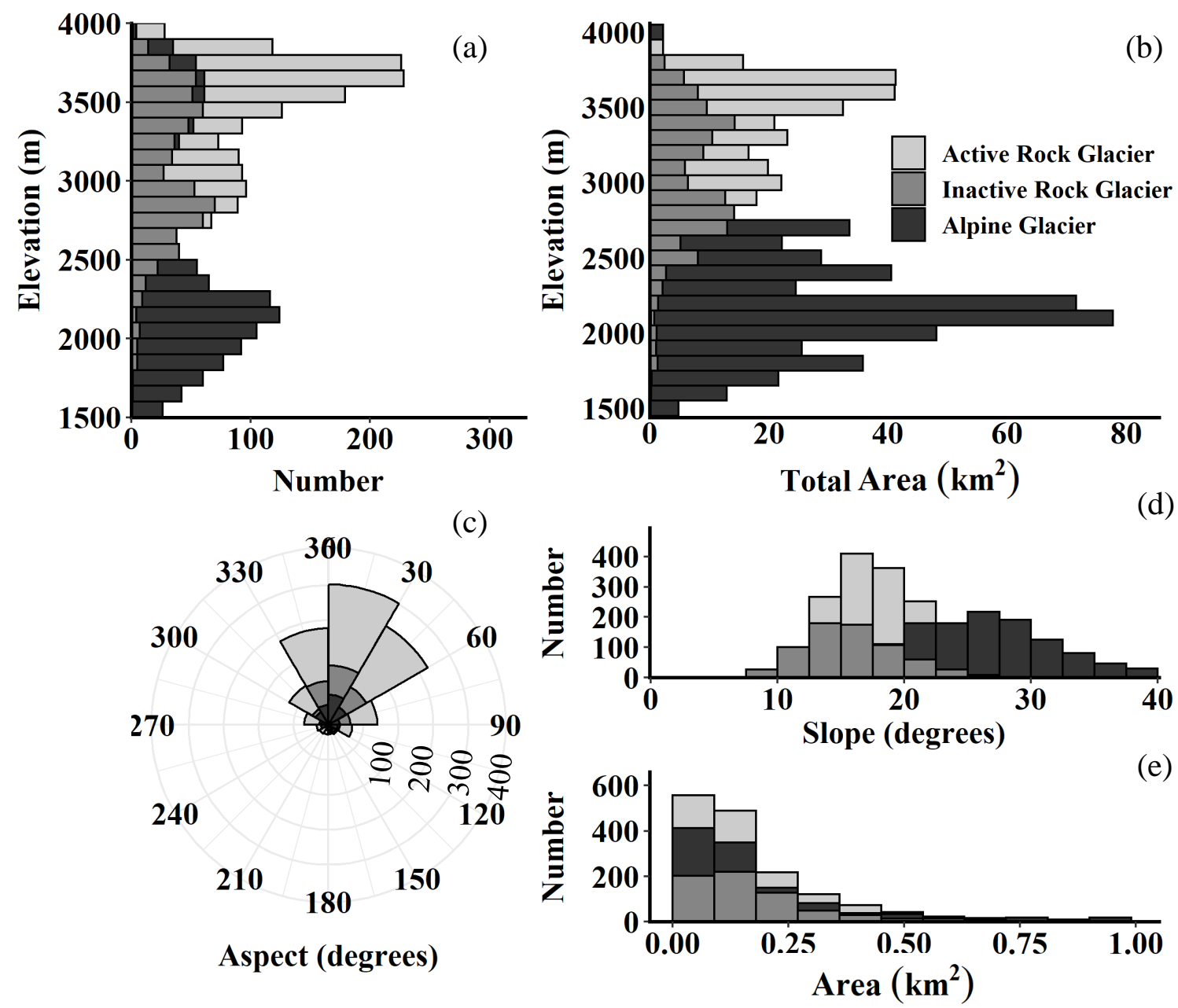

Figure 5-11: Overlapping histograms with the topographic characteristics of alpine glaciers, active and inactive rock glaciers for elevation (a), elevation and total area (b), aspect (c), slope (d), and area (e). Each interval is denoted by the highest value in each interval. Area is in intervals of $0.09 \mathrm{~km}^{2}$. Elevation is in intervals of $100 \mathrm{~m}$. Aspect is in intervals of $30^{\circ}$. Slope is in intervals of $2.5^{\circ}$.

Climatically, alpine glaciers have statistically significant different seasonal air temperatures and more winter accumulation (Table 5-10, Figure 5-13). Mountain ranges with mostly alpine glaciers have greater winter precipitation than ranges mostly populated by rock glaciers (Figure 5-13). Ranges with winter precipitation greater than about 1180mm are almost entirely populated with alpine glaciers (Pacific Northwest) and 
ranges with less winter precipitation are populated with mostly rock glaciers. Two exceptions are the Lewis and Swan Ranges in Montana and the Wind River Range in Wyoming, which have winter precipitation less than $1180 \mathrm{~mm}$, and $20-36 \%$ of the combined total are rock glaciers. It is clear from figures 5-13 and 5-14, that the dominant climatic factor determining the presence of an alpine or rock glacier is winter precipitation and not temperature. That temperature is statistically different is a result of outliers as seen in Figure 5-13, a few very warm rock glaciers and a few very cold alpine glaciers.
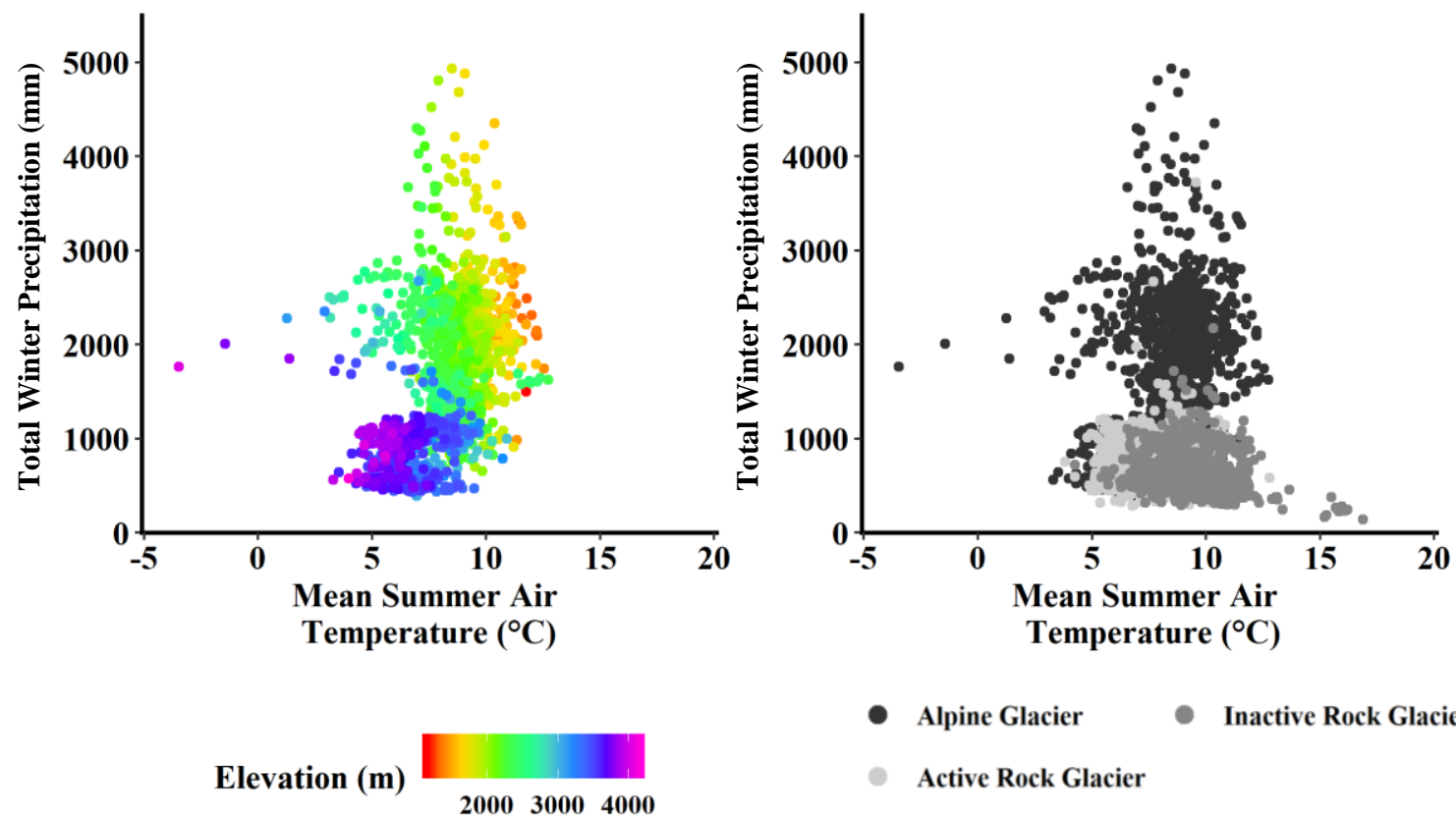

- Alpine Glacier Inactive Rock Glacier Active Rock Glacier

Figure 5-12: Climate of alpine glaciers in relation to elevation and rock glaciers. 
Table 5-10: Mean and standard deviation (Std Dev), of climatic characteristics of alpine glaciers and active and inactive rock glaciers. Bold represent characteristics that are statistically different from alpine glaciers ( $t$-test, $\mathrm{p}$-value $<0.05$ ). Temp is temperature in ${ }^{\circ} \mathrm{C}$ and Precip is precipitation in $\mathrm{mm}$.

\begin{tabular}{lrrrrrr} 
& \multicolumn{3}{c}{} & \multicolumn{2}{c}{ Active Rock } & \multicolumn{2}{c}{ Inactive Rock } \\
& \multicolumn{2}{c}{ Alpine Glacier } & \multicolumn{2}{c}{ Glacier } & \multicolumn{2}{c}{ Glacier } \\
& Mean & Std Dev & Mean & Std Dev & Mean & Std Dev \\
\cline { 2 - 7 } & 8.1 & 1.7 & $\mathbf{7 . 8}$ & 1.2 & $\mathbf{9 . 3}$ & 1.7 \\
Summer Air Temp & 319 & 141 & $\mathbf{2 3 8}$ & 84 & $\mathbf{2 4 2}$ & 67 \\
Summer Precip & -5.4 & 2.4 & $\mathbf{- 7 . 0}$ & 1.4 & $\mathbf{- 6 . 0}$ & 1.9 \\
Winter Air Temp & 1610 & 797 & $\mathbf{7 0 8}$ & 233 & $\mathbf{6 5 5}$ & 249 \\
Winter Precip & 0.29 & 2.0 & $\mathbf{- 0 . 7}$ & 1.2 & 0.5 & 1.8 \\
Annual Air Temp & 2251 & 1033 & $\mathbf{1 1 1 5}$ & 259 & $\mathbf{1 0 6 8}$ & 288 \\
Annual Precip & 2252 & 720 & $\mathbf{3 3 8 5}$ & 382 & $\mathbf{3 0 7 3}$ & 462 \\
Elevation (m) & & & & & &
\end{tabular}

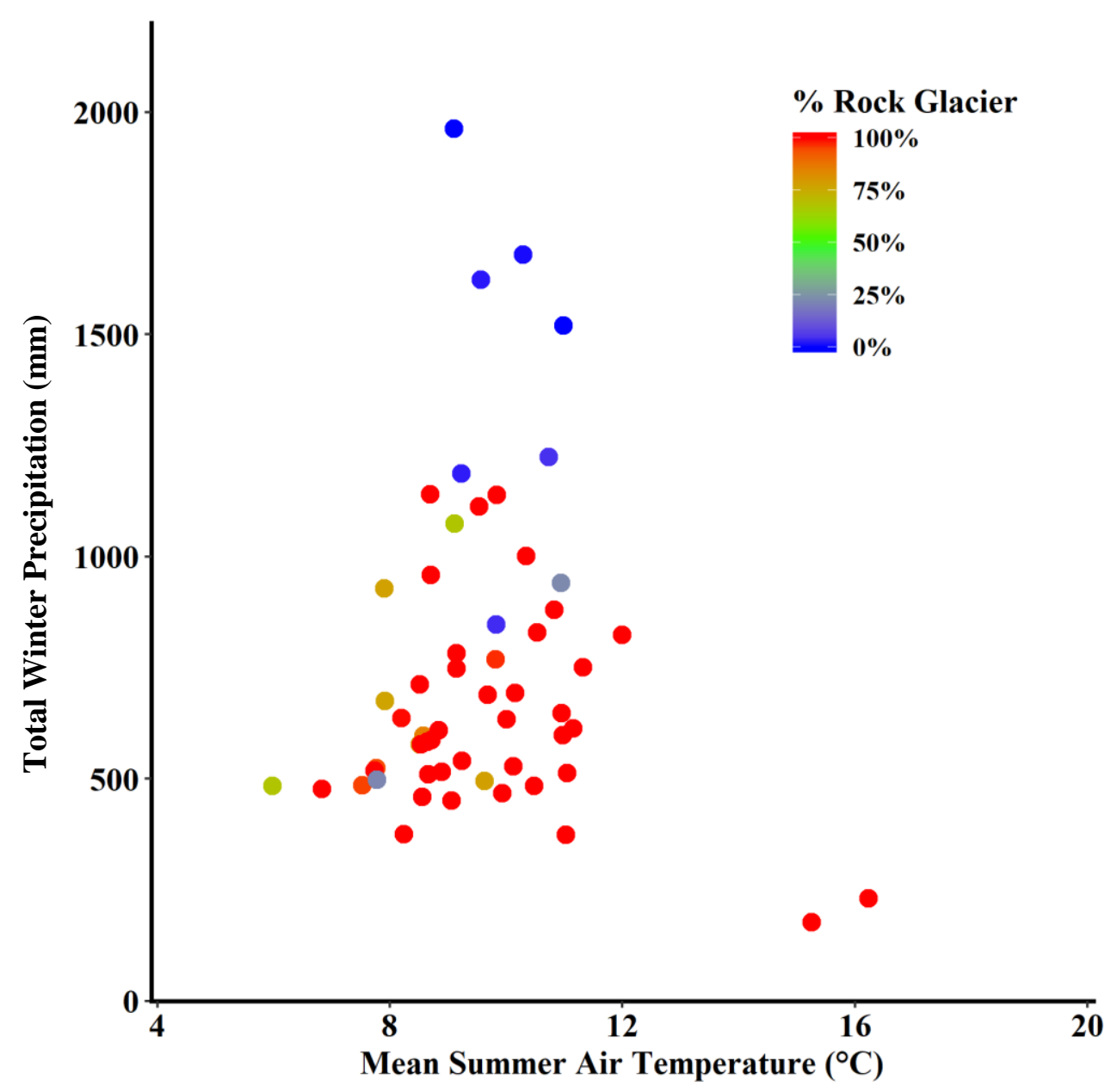

Figure 5-13: Average temperature and precipitation of all alpine glaciers and rock glaciers for each mountain range. 


\section{Ice Exposed Rock Glaciers}

There are 175 rock glaciers (171 active, 4 inactive) that were described as ice exposed rock glaciers (IERG). California has the largest number of IERG, 83 (27.94 $\mathrm{km}^{2}$ ), a little less than the rest of the states combined (Table 5-11). They are absent from Utah and New Mexico. IERG have a normal elevation distribution with a mean of 3353 $\mathrm{m}$, which is statistically no different from active rock glaciers but different than inactive rock glaciers and alpine glaciers (Table 5-12, Figure 5-14). IERG have slopes most similar to active rock glaciers, lower than alpine glaciers, and higher than inactive rock glaciers.

Table 5-11: Elevation and area ice exposed rock glaciers (IERG) per state. Max is maximum, Min is minimum.

\begin{tabular}{lrrrrrrr} 
& & \multicolumn{3}{c}{ Elevation $(\mathrm{m})$} & \multicolumn{3}{c}{ Area $\left(\mathrm{km}^{2}\right)$} \\
\cline { 3 - 8 } State & Number & Max & Min & Mean & Mean & Median & Total \\
\hline Washington & 1 & 2059 & 1793 & 1947 & 0.15 & 0.15 & 0.15 \\
Oregon & 3 & 2834 & 2515 & 2711 & 0.18 & 0.13 & 0.55 \\
California & 83 & 4116 & 3011 & 3601 & 0.34 & 0.28 & 27.94 \\
Idaho & 10 & 3320 & 2648 & 2855 & 0.28 & 0.20 & 2.83 \\
Nevada & 1 & 3507 & 3254 & 3368 & 0.32 & 0.32 & 0.32 \\
Montana & 38 & 3701 & 2096 & 3068 & 0.55 & 0.36 & 20.87 \\
Wyoming & 31 & 3898 & 2627 & 3235 & 0.45 & 0.35 & 13.98 \\
Utah & 0 & - & - & - & - & - & - \\
Colorado & 8 & 4045 & 3389 & 3621 & 0.24 & 0.20 & 1.95 \\
New Mexico & 0 & - & - & - & - & - & - \\
\hline Total & 175 & 4116 & 1793 & 3353 & 0.39 & 0.29 & 68.57
\end{tabular}


Table 5-12: Mean and standard deviation (Std Dev), of topographic characteristics of ice exposed rock glaciers (IERG), alpine glaciers and active and inactive rock glaciers. Bold represent characteristics that are statistically different from IERG (t-test, p-value < 0.05).

\begin{tabular}{|c|c|c|c|c|c|c|c|c|}
\hline \multirow[b]{3}{*}{ Flevation (m) } & \multicolumn{2}{|c|}{ IERG } & \multicolumn{2}{|c|}{$\begin{array}{l}\text { Active Rock } \\
\text { Glacier }\end{array}$} & \multicolumn{2}{|c|}{$\begin{array}{c}\text { Inactive Rock } \\
\text { Glacier }\end{array}$} & \multicolumn{2}{|c|}{ Alpine Glacier } \\
\hline & Mean & $\begin{array}{l}\text { Std } \\
\text { Dev }\end{array}$ & Mean & $\begin{array}{l}\text { Std } \\
\text { Dev }\end{array}$ & Mean & Std Dev & Mean & $\begin{array}{l}\text { Std } \\
\text { Dev }\end{array}$ \\
\hline & 3353 & 720 & 3385 & 382 & 3073 & 462 & 2252 & 720 \\
\hline $\begin{array}{l}\text { Slope } \\
\text { (degrees) }\end{array}$ & 19 & 3 & 18 & 4 & 16 & 4 & 26 & 6 \\
\hline Area $\left(\mathrm{km}^{2}\right)$ & 0.39 & 0.36 & 0.18 & 0.19 & 0.20 & 0.20 & 0.43 & 0.93 \\
\hline
\end{tabular}
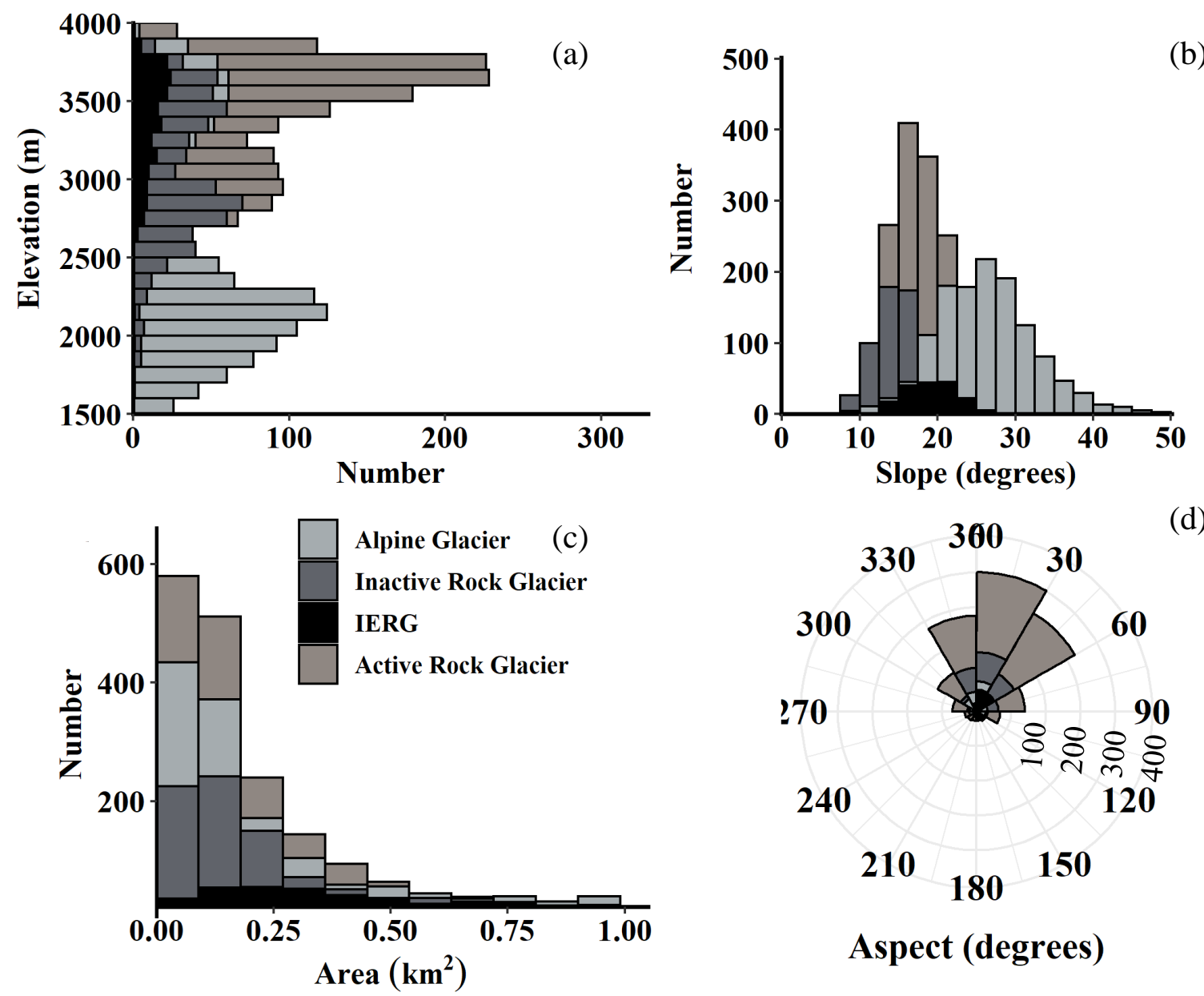

Aspect (degrees)

Figure 5-14: The topographic characteristics of ice exposed rock glaciers (IERG), active and inactive rock glaciers and alpine glaciers for elevation (a), aspect (d), slope (d), and area (d). 
The annual and seasonal values of precipitation and air temperature for the IERG were statistically different from alpine glaciers, and active, inactive rock glaciers, except for annual air temperature of active rock glaciers (Table 5-13; Figure 5-16). Mean summer air temperatures of the IERG are cooler than the other features with more winter precipitation than the other rock glaciers

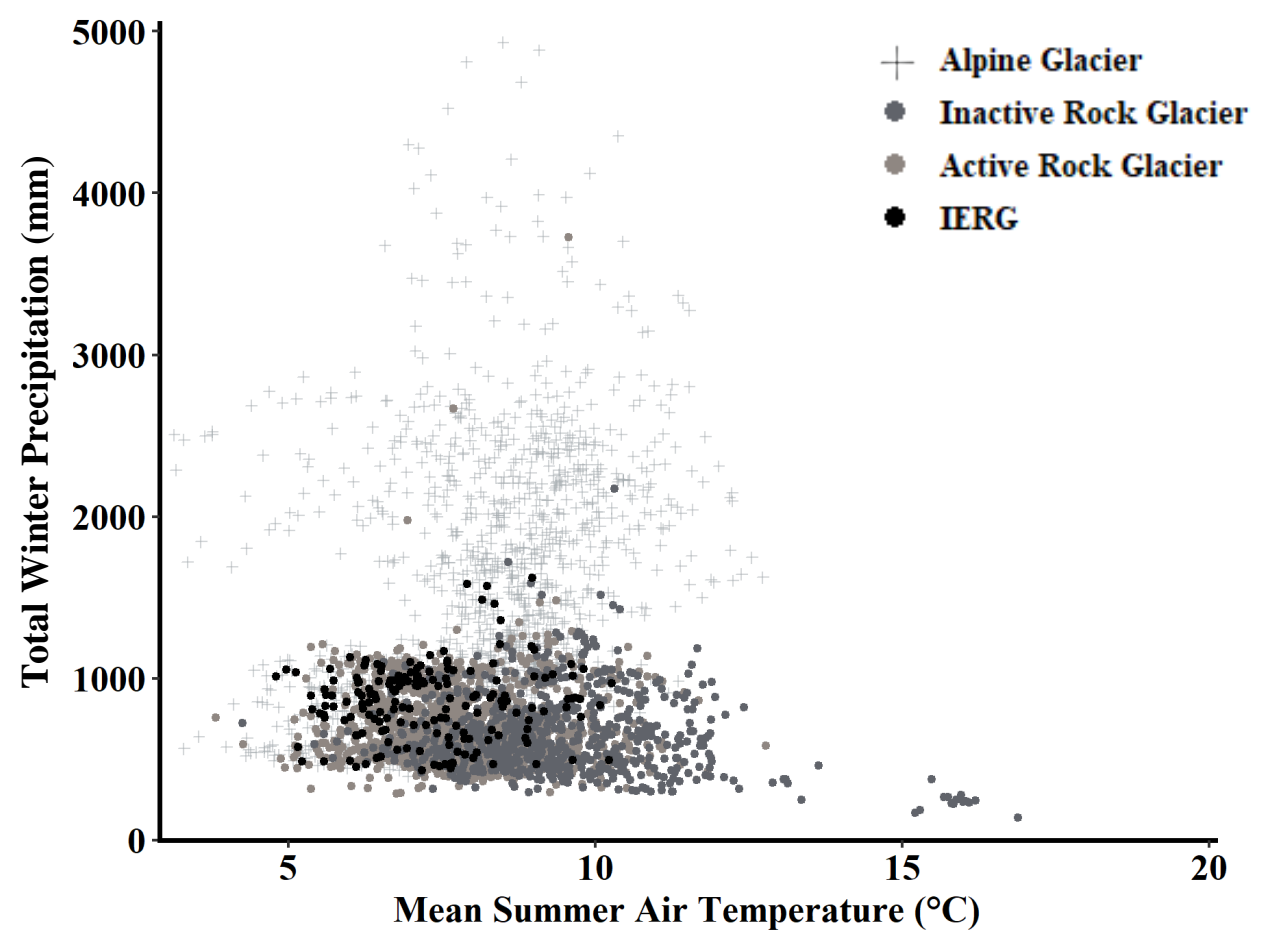

Figure 5-15: Total winter precipitation and summer temperature for ice exposed rock glaciers (IERG), active and inactive rock glaciers, and alpine glaciers in the western US. 
Table 5-13: Mean and standard deviation (Std Dev), of climatic characteristics of ice exposed rock glaciers (IERG), alpine glaciers and active and inactive rock glaciers. Bold statistically significant differences from IERG (t-test, p-value <0.05). Temp is temperature in ${ }^{\circ} \mathrm{C}$ and Precip is precipitation in $\mathrm{mm}$.

\begin{tabular}{lrrrrrrrr} 
& \multicolumn{2}{c}{ IERG } & \multicolumn{2}{c}{ Active Rock } & \multicolumn{2}{c}{ Inactive } & \multicolumn{2}{c}{ Alpine } \\
& \multicolumn{2}{c}{ Glacier } & \multicolumn{2}{c}{ Rock Glacier } & \multicolumn{2}{c}{ Glacier } \\
& Mean & Std & Mean & Std & Mean & Std & Mean & Std \\
& Dev & & Dev & & Dev & & Dev \\
\cline { 2 - 9 } & 7.3 & 1.2 & $\mathbf{7 . 8}$ & 1.2 & $\mathbf{9 . 3}$ & 1.7 & $\mathbf{8 . 1}$ & 1.7 \\
Summer Air Temp & 177 & 102 & $\mathbf{2 3 8}$ & 84 & $\mathbf{2 4 2}$ & 67 & $\mathbf{3 1 9}$ & 141 \\
Summer Precip & -6.7 & 1.6 & $\mathbf{- 7 . 0}$ & 1.4 & $\mathbf{- 6 . 0}$ & 1.9 & $\mathbf{- 5 . 4}$ & 2.4 \\
Winter Air Temp & 852 & 234 & $\mathbf{7 0 8}$ & 233 & $\mathbf{6 5 5}$ & 249 & $\mathbf{1 6 1 0}$ & 797 \\
Winter Precip & -0.83 & 1.2 & -0.7 & 1.2 & $\mathbf{0 . 5}$ & 1.8 & $\mathbf{0 . 2 9}$ & 2.0 \\
Annual Air Temp & 1194 & 247 & $\mathbf{1 1 1 5}$ & 259 & $\mathbf{1 0 6 8}$ & 288 & $\mathbf{2 2 5 1}$ & 1033 \\
Annual Precip & 3353 & 720 & 3385 & 382 & $\mathbf{3 0 7 3}$ & 462 & $\mathbf{2 2 5 2}$ & 720 \\
Elevation (m) & & & & & & & &
\end{tabular}

\section{Features of Interest}

Although not an intended subject of this thesis and given that features of interest (FOI)

may be genetically related to rock glaciers (Haeberli, 1985), it seemed fruitful to examine them in a cursory way. I found 7852 FOI across the western US (Table 6-1, Figure 5-16). They are found in mountain ranges with and without rock glaciers and the rank order of the most FOI populated states is similar to those of rock glaciers, except for Utah and Nevada. The area of individual FOIs was not calculated; however, to roughly estimate the area of FOI, 20 randomly chosen FOI were digitized, and the average area was about 0.15 $\mathrm{km}^{2}$. Mountain ranges with a large number rock glaciers generally have a larger number of FOI (Figure 5-17). 


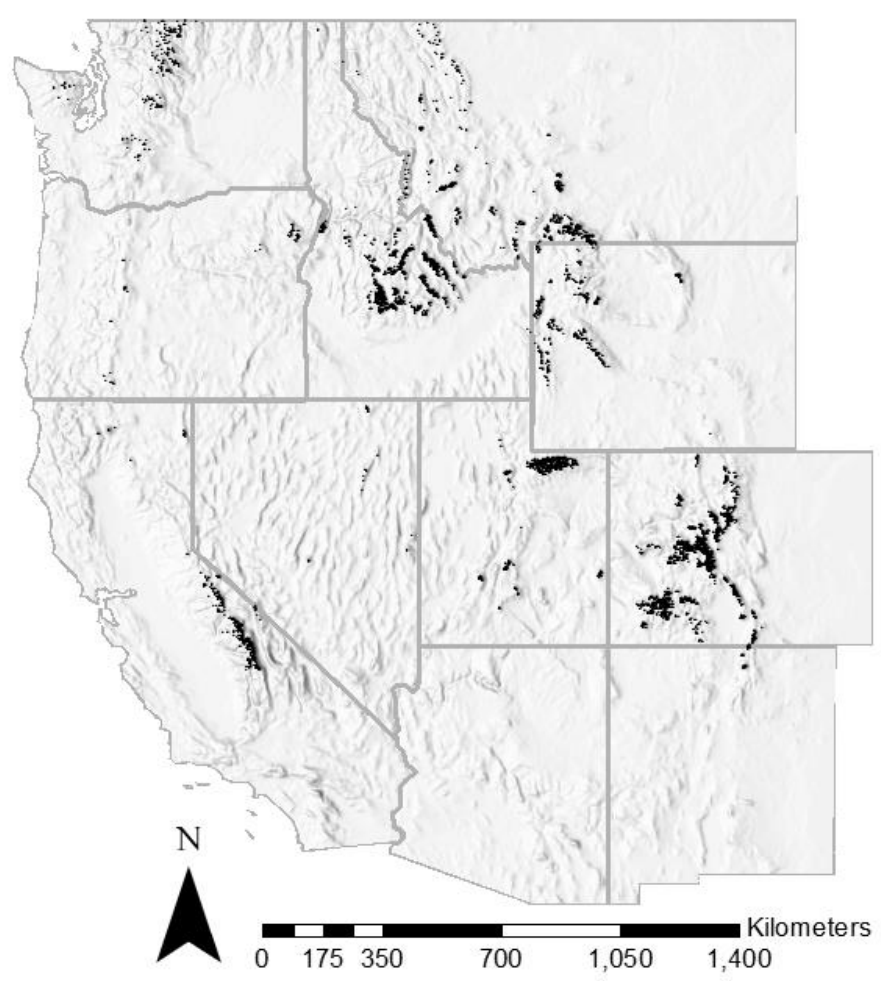

Figure 5-16: Distribution of features of interest across the western United States.

Table 5-14: The number of features of interest (FOI) in each state.

\begin{tabular}{lr} 
State & FOI \\
\hline WA & 281 \\
OR & 80 \\
CA & 679 \\
ID & 1630 \\
NV & 169 \\
MT & 974 \\
WY & 523 \\
UT & 845 \\
CO & 2567 \\
NM & 104 \\
\hline Total & 7852
\end{tabular}




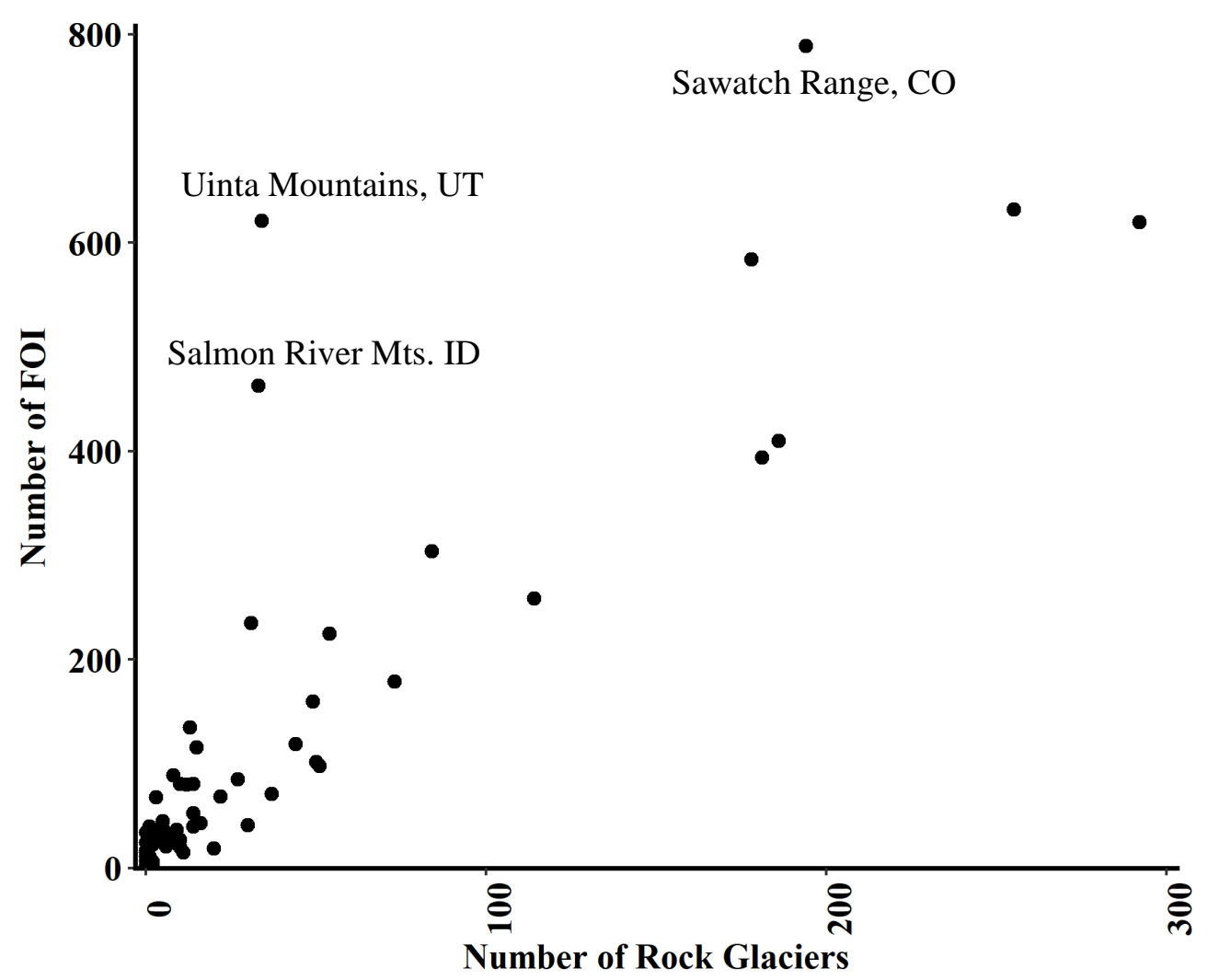

Figure 5-17: Number of rock glaciers and features of interest (FOI) in each mountain range.

Like rock glaciers the FOI increase in elevation to the south and east (Figure F-1) and exhibit a bimodal distribution with peaks at $3457 \mathrm{~m}$ and $2693 \mathrm{~m}$, indicating two geographic groupings close to those of rock glaciers (Figure 5-18; Figure F-2) The mean elevation of FOI is statistically different and higher than inactive rock glaciers and lower than active rock glaciers (Table 5-15). FOI have similar aspects to those of rock glaciers and similar slopes to active rock glaciers but statistically different slopes from inactive rock glaciers (Figure 5-18). Climatically, winter, and annual air temperature and precipitation of FOI are not statistically different from inactive rock glaciers (Table 516). Whereas summer air temperature and precipitation are statistically different to both active and inactive rock glaciers. FOI has higher summer temperature than active but 
lower than inactive rock glaciers. Precipitation for both active and inactive rock glaciers are both lower than FOI.

Table 5-15: Mean and standard deviation (Std Dev), of topographical characteristics of features of interest (FOI). Bold represent values that are statistically different (t-test, pvalue $<0.05$ ) from the FOI.

\begin{tabular}{lrrrrrr} 
& \multicolumn{2}{c}{ FOI } & \multicolumn{2}{c}{ Active Rock } & \multicolumn{2}{c}{ Inactive Rock } \\
& Mean & Std Dev & Mean & Std Dev & Mean & Std Dev \\
\cline { 2 - 7 } & 3110 & 488 & $\mathbf{3 3 8 5}$ & 382 & 3073 & 462 \\
Elevation (m) & 17 & 8 & 18 & 4 & $\mathbf{1 6}$ & 4
\end{tabular}
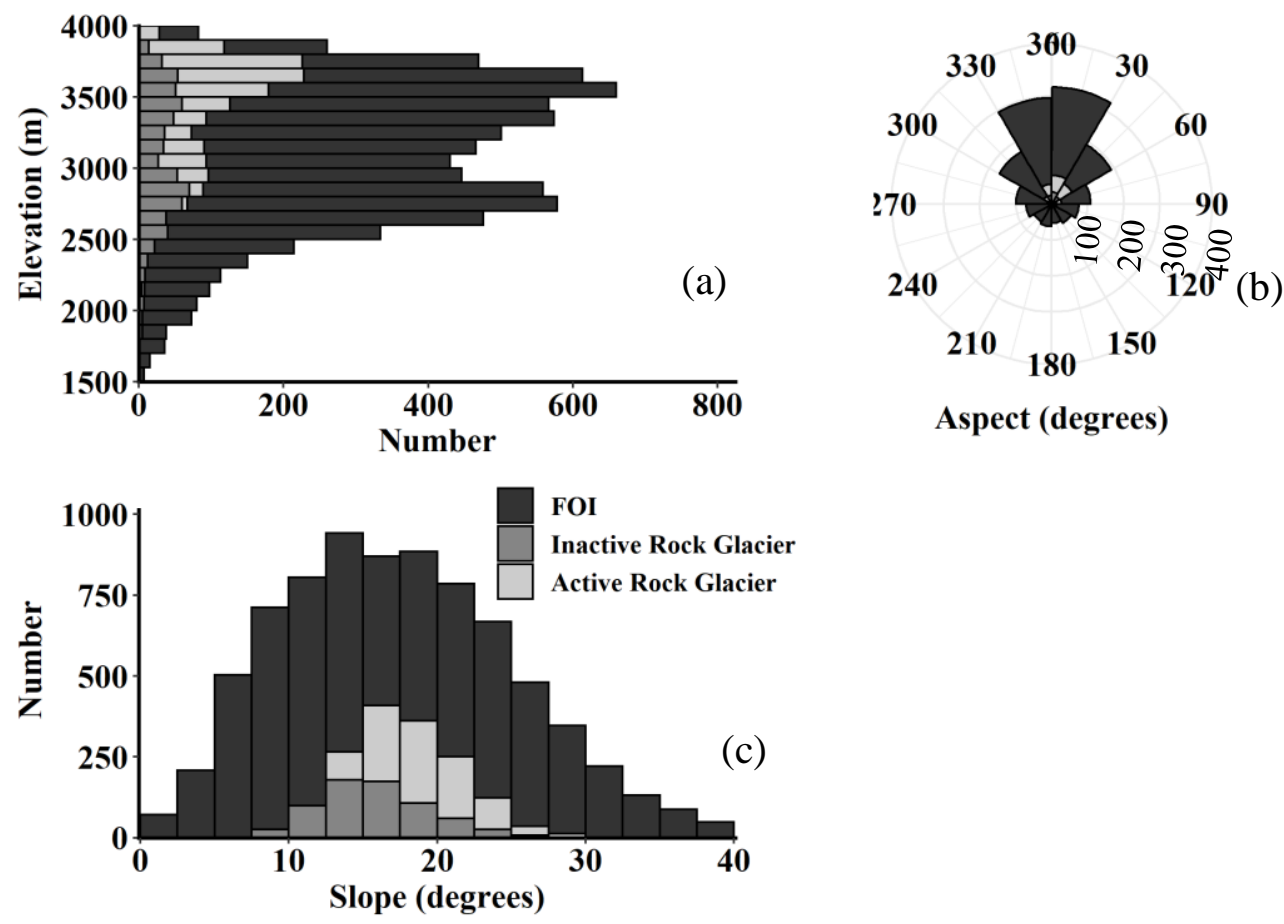

Aspect (degrees)

Figure 5-18: Topographic characteristics of elevation (a), aspect (b), and slope (c) of features of interest (FOI) compared to active and inactive rock glaciers. 
Table 5-16: Mean and standard deviation (Std Dev), of climate characteristics of features of interest (FOI) and active and inactive rock glaciers. Bold represent characteristics that are statistically different from FOI (t-test, p-value $<0.05$ ). Temp is temperature in ${ }^{\circ} \mathrm{C}$ and Precip is precipitation in $\mathrm{mm}$.

\begin{tabular}{|c|c|c|c|c|c|c|}
\hline & \multicolumn{2}{|c|}{ FOI } & \multicolumn{2}{|c|}{$\begin{array}{c}\text { Active Rock } \\
\text { Glacier }\end{array}$} & \multicolumn{2}{|c|}{$\begin{array}{c}\text { Inactive Rock } \\
\text { Glacier }\end{array}$} \\
\hline & & Std & & Std & & Std \\
\hline & Mean & Dev & Mean & Dev & Mean & Dev \\
\hline Summer Air Temp & 9.1 & 1.7 & 7.8 & 1.2 & 9.3 & 1.7 \\
\hline Summer Precip & 288 & 73 & 238 & 84 & 242 & 67 \\
\hline Winter Air Temp & -6.0 & 1.8 & -7.0 & 1.4 & -6.0 & 1.9 \\
\hline Winter Precip & 657 & 259 & 708 & 233 & 655 & 249 \\
\hline Annual Air Temp & 0.3 & 1.6 & -0.7 & 1.2 & 0.5 & 1.8 \\
\hline Annual Precip & 1051 & 296 & 1115 & 259 & 1068 & 288 \\
\hline Insolation $\left(\mathrm{WH} \mathrm{m} \mathrm{m}^{-2}\right)$ & 1511005 & 728847 & 1474120 & 621894 & 1448413 & 621894 \\
\hline Elevation (m) & 3110 & 488 & 3385 & 382 & 3073 & 462 \\
\hline
\end{tabular}

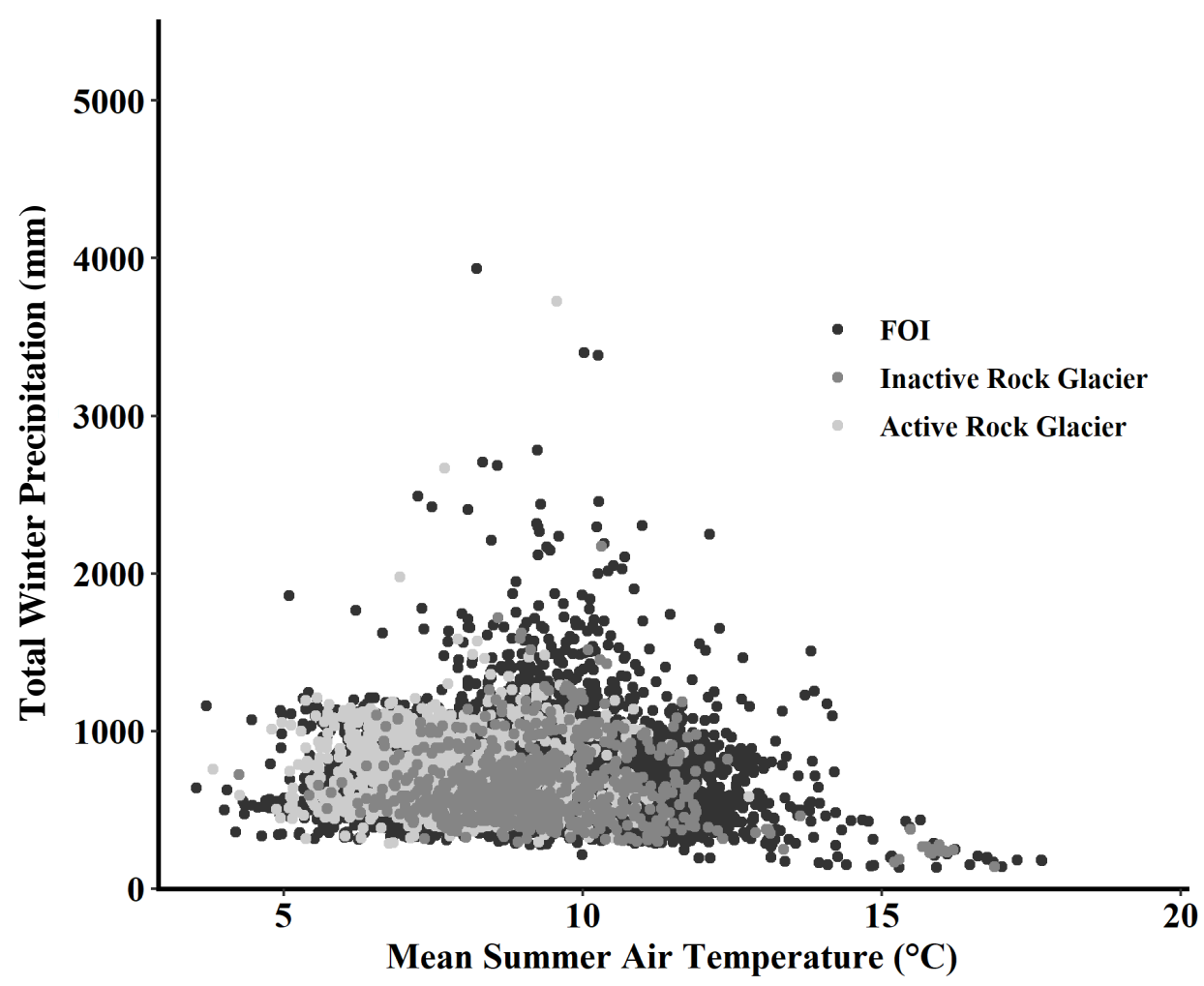

Figure 5-19: Climate of features of interest, and active and inactive rock glaciers. 


\subsection{Discussion}

Rock glacier classification schemes are subjective and use morphology for identification and classification. This has led to inconsistent criteria and controversies regarding rock glacier identification. Characteristics have included steep frontal slopes, smooth surfaces, pitted surfaces, ridge and furrowed surfaces, lack of vegetation cover, some vegetation cover, a lobate form with certain length-width radios, and positive relief. These characteristics may be well-defined or subtle. Most inventories use the presence of ridges and furrows to indicate movement, however, rock glaciers with no such features move at similar speeds (Liu et al., 2013). Some rock glacier classifications include many (>3) characteristics (Millar and Westfall, 2019; Millar and Westfall, 2008; Johnson, 2018; Florentine et al., 2014), and others include only a few (<3) characteristics (Janke, 2007; Krainer and Ribis, 2012; Delaloye and Echelard, 2020). Steep frontal slopes are the only characteristic common to all rock glacier inventories. In an attempt to standardize guidelines for rock glacier inventories, Delaloye and Echelard (2020) recommend a more restrictive approach with the characteristics of front, lateral margins, and optional ridge and furrow surface morphology.

My inventory follows the restrictive approach and meets the definition of a rock glacier in that they portray characteristics that signify internal ice and movement (Cogley et al., 2011; Delaloye and Echelard, 2020). I characterize that rock glaciers must exhibit positive relief (signifying internal ice), over-steepened lower margins (signifying movement and possible internal ice), and significant movement, indicated by its apparent flow extending into the valley from the source region. This distinguishes rock glaciers 
from talus accumulations or protalus ramparts, both of which may contain ice but are not moving. The most important difference between my inventory and others is the indication of significant movement whereby the feature extends into the valley rather than restricted to the base of the valley wall. Consequently, my inventory has considerably fewer rock glaciers in comparison to published regional inventories.

I subclassified the rock glaciers into active and inactive based on morphology. Active rock glaciers move and contain internal ice and are characterized by having oversteepened slopes and a dilated appearance. Inactive rock glaciers no longer move and may or may not contain internal ice and are characterized by having gentler slopes and a deflated appearance. Other inventories have also used two subcategories (Johnson et al., 2007; Esper Angillieri, 2009; Krainer and Ribis, 2012), in contrast to some inventories that had three subclassifications - active, inactive, and relict (Esper Angillieri, 2009; Johnson et al., 2007; Krainer and Ribis, 2012).

For context, I compare my results to inventories compiled for the Tyrolian Alps, Austria (Krainer and Ribis, 2012) and the Andes, Argentina (Falaschi et al., 2014), which also encompass large regions. The criteria used to identify rock glaciers in both Austria and Argentina are similar to mine including the steepness of the front slope, however, they included other criteria including ridges and furrows and signs of surface degradation. The Austrian inventory used a three-category classification system, while the Argentina inventory used a two-category system like in this study. The number of rock glaciers and total area in the western US are similar to those in the Tyrolean Alps, Austria (Table 6-1), a result similar to that reported by Fountain et al. (2017) for alpine 
glaciers. However, the mean area of rock glaciers in the western US is twice that of rock glaciers in Austria and twice that of intact rock glaciers in Argentina. The reasons for this are unclear. The few area measurements of FOI suggest that they too are larger.

Table 6-1: Comparisons between this study and international rock glacier inventories. Num is number of rock glaciers Mean and Total areas refer to active or intact rock glaciers. Class is the classification used by the authors.

\begin{tabular}{lcrrr} 
Location & Num & $\begin{array}{c}\text { Mean } \\
\text { Area }\left(\mathrm{km}^{2}\right)\end{array}$ & $\begin{array}{c}\text { Total } \\
\text { Area }\left(\mathrm{km}^{2}\right)\end{array}$ & Num Class \\
\hline western US & 2249 & 0.19 & 159.3 & 1564 Active \\
& & & & 685 Inactive \\
Austria & 3145 & 0.08 & 167.2 & 517 Active \\
& & & & 915 Inactive \\
& & & & 1713 Fossil \\
Argentina & 448 & 0.09 & 59 & 422 Intact \\
& & & & 66 Relict
\end{tabular}

Within the western US, Nevada and New Mexico have the fewest rock glaciers possibly because of the relatively high summer air temperature and low precipitation. There are slightly more rock glaciers in Washington and Oregon probably due to its maritime climate of cool air temperatures and greater winter precipitation, which favors the development of alpine glaciers over rock glaciers (Barsch, 1996). Indeed, this region has the most number and area of alpine glaciers in the western US. The continental climate elsewhere in the western US tends to favor rock glaciers, except for a few ranges such as the Wind River Range of Wyoming. Rock glaciers increase in elevation to the south and east, from Washington State due to increasing summer air temperature and less precipitation. This trend of more rock glaciers in more continental climates is seen elsewhere (Humlum, 1988; Haeberli et al., 2006). 
The bimodal elevation distribution of rock glaciers suggests different climate regimes. The low elevation $(<3245 \mathrm{~m})$ rock glaciers are mainly found in the cooler, wetter maritime climate of the PNW (Washington, Oregon, Idaho, western Montana). The largest number of high elevation $(>3245 \mathrm{~m})$ rock glaciers are found in the warmer, drier continental climates of Colorado and California. Initially, it was somewhat surprising to find that rock glaciers have more shallow slopes than alpine glaciers, given the more ductile behavior of ice compared to an ice-rock mixture (Cuffey and Paterson, 2010). The population of alpine glaciers is dominated by very small glaciers that cling to steeper slopes than the larger glaciers.

In the western US, rock glaciers on the north-facing slopes extend to lower elevations than on south-facing slopes, similar to other regions in the Northern Hemisphere (Barsch, 1996; Krainer and Ribis, 2012; Janke, 2007; Blagbrough, 1991; Falaschi et al., 2014; Brazier et al., 1998). This tendency can be explained by solar radiation and snow accumulation. Northerly facing slopes receive less solar radiation and easterly-facing slopes receive more wind-transported snow accumulation due to the dominant westerly winds (Barsch, 1996). Active and inactive form have similar characteristics; however, inactive rock glaciers are generally found at lower elevations and warmer temperatures than active rock glaciers because they presumably formed in a prior climate that was colder and wetter than the present-day climate (Janke, 2007; Krainer and Ribis, 2012; Kerschner, 1978; Brazier et al., 1998). This orientation may also be due to rock glaciers occupation of cirques that were glacially-carved in past epochs 
(Janke, 2007; Brazier et al., 1998). As shown, alpine glaciers favor the same orientations as rock glaciers.

Within the western US, there are about twice as many rock glaciers as alpine glaciers, but less area and volume (Table 6-2). Similar results are found in Austria and Argentina (Kellerer-Pirklbauer et al., 2012; Barcaza et al., 2017; Krainer and Ribis, 2012). In the western US, the total volume of ice stored in both active and inactive rock glaciers combined is $6.99 \pm 0.278 \mathrm{~km}^{3}$. This is smaller than the water equivalent volume of alpine glaciers $12.37 \mathrm{~km}^{3}$ (Fountain et al., 2017). The ice volume in rock glaciers in the western US is greater than in Argentina and Austria.

Table 6-2: Comparison between this study to international rock glacier inventories of rock glaciers (RG) and alpine glaciers (AG).

\begin{tabular}{lcccccc} 
& \multicolumn{2}{c}{ Number } & \multicolumn{2}{c}{ Total Area $\left(\mathrm{km}^{2}\right)$} & \multicolumn{2}{c}{ Total Volume $\left(\mathrm{km}^{3}\right)$} \\
& $\mathrm{RG}$ & $\mathrm{AG}$ & $\mathrm{RG}$ & $\mathrm{AG}$ & $\mathrm{RG}$ & $\mathrm{AG}$ \\
\cline { 2 - 7 } western US & 2249 & 1276 & 421.2 & 554.2 & $6.99 \pm 0.278$ & 12.37 \\
Austria & 3145 & 3770 & 286.2 & 2050 & 2.37 & - \\
Argentina & 1472 & 780 & 289.9 & 1197 & $0.19-0.27$ & -
\end{tabular}

Rock glaciers are co-located in regions with small alpine glaciers suggesting similar formation climates. However, heavy winter precipitation (snowfall) favors alpine glaciers over rock glaciers (Barsch, 1996). Correspondingly, low winter precipitation favors rock glaciers. Alpine glaciers, and ice-exposed, active, and inactive rock glaciers exist along a gradient of winter precipitation and summer temperature. Active rock glaciers are found at the coolest summer air temperatures, mean $7.8^{\circ} \mathrm{C}$, with a mean winter precipitation of $708 \mathrm{~mm}$. Alpine glaciers have slightly warmer temperatures, mean $8.1^{\circ} \mathrm{C}$, but have the highest mean winter precipitation, $1610 \mathrm{~mm}$. Inactive rock glaciers 
have the highest summer temperatures, $9.3^{\circ} \mathrm{C}$, and lowest winter precipitation, $655 \mathrm{~mm}$. Few rock glaciers are found where winter precipitation exceeds $1200 \mathrm{~mm}$. The annual temperature of $0^{\circ} \mathrm{C} \pm 1^{\circ} \mathrm{C}$ and annual precipitation of $1000 \mathrm{~mm} \pm 100 \mathrm{~mm}$ is similar to rock glaciers in other temperate climates globally which have mean annual temperatures below $0{ }^{\circ} \mathrm{C} \pm 2.5^{\circ} \mathrm{C}$ and annual precipitation less than $2000 \mathrm{~mm}$ (Barsch, 1996; Haeberli 1985; Brenning, 2005; Charbonneau and Smith, 2018; Scotti et al. 2013). IERG are found in cooler and wetter conditions than active rock glaciers, $7.3^{\circ} \mathrm{C}, 1194 \mathrm{~mm} ; 7.8^{\circ} \mathrm{C}, 708$ $\mathrm{mm}$, respectively, but drier than alpine glaciers, $8.1^{\circ} \mathrm{C}, 1610 \mathrm{~mm}$.

Most (FOI) appear to be protalus ramparts, which form from the accumulation of rocky debris that slides or rolls over a snow patch and accumulates at the foot of a talus slope (Ballantyne, 1987). In the western US, the number of FOI (7852) greatly exceeds that of rock glaciers (2249). They form in similar climates and are co-located in regions with rock glaciers consistent with the hypothesis that they may be genetically similar to rock glaciers (Scapozza et al., 2011; Haeberli et al., 1985; Hedding, 2011). 


\subsection{Conclusions}

The rock glacier inventory identified 2249 rock glaciers $\left(421.2 \mathrm{~km}^{2}\right)$ that populate 10 states. Of these, $1564\left(285.06 \mathrm{~km}^{2}\right)$ were classified as active rock glaciers and 685 $\left(136.14 \mathrm{~km}^{2}\right)$ as inactive. The distinguishing characteristics for active rock glaciers included a dilated structure, steep frontal margins that exceed the angle of repose, and, importantly, flow away from the valley wall. In contrast, inactive rock glaciers appeared to be deflated forms with less steep frontal margins. My inventory included fewer rock glaciers compared to previously published inventories due to the more restrictive criterion of significant movement, indicated by the landform's extension well into the valley or occupies the valley axis. I mostly agree with prior inventory in that the features are probably permafrost, only a few features were eliminated from the prior inventories except for Kinworthy's inventory in New Mexico. The major difference in the inventories is how we define what a rock glacier is. Most of the features that were not regarded as rock glaciers, 7852, were classified as a 'feature of interest' (FOI), suggesting that ice was present, but not moving.

Like alpine glaciers, rock glacier and FOI elevations increase from the northwest, Washington State, to the southeast, Colorado. This trend follows the climatic trends of lower precipitation and warmer summer potential air temperatures. Two populations of rock glaciers are found; low elevation ones below $3245 \mathrm{~m}$ (mean $2806 \mathrm{~m}$ ) and high elevation ones above $3245 \mathrm{~m}$ (mean $3523 \mathrm{~m}$ ). The former are a relatively small population found in the cooler, wetter maritime climate of the Pacific Northwest, and the 
latter, larger population in both number and area is located in the warmer, drier continental climate elsewhere in the western US.

Rock glaciers form in cold local climates with a moderate amount of winter precipitation $(<1200 \mathrm{~mm})$. They form on northern slopes because they receive more snow accumulation due to the dominant westerly winds. Snow must be abundant but does not exceed the rate of rockfall. If the ice accumulation is greater than the rockfall than alpine glaciers occur. When comparing alpine glaciers and active and inactive rock glaciers environments. Alpine glaciers have the coolest summer temperatures and the highest winter precipitation. Both active and inactive rock glaciers have warmer temperatures and less precipitation. Active rock glaciers occur at slightly cooler temperatures than inactive.

The total water equivalent volume of ice stored in active rock glaciers is estimated to be $5.9 \mathrm{~km}^{3}$ and in inactive rock glaciers $1.09 \mathrm{~km}^{3}$, totaling $6.99 \pm 0.278 \mathrm{~km}^{3}$. This is smaller than the water equivalent volume alpine glaciers $12.37 \mathrm{~km}^{3}$ (Fountain et al., 2017).

Defining the locations of rock glaciers are in the western US will help our understanding of the present and future hydrological processes in mountainous regions. As alpine glaciers disappear, rock glaciers may become an important water resource. Not only do they provide water for agricultural use, but they also naturally regulate bioavailable nutrients and heavy metal concentrations in water sources that are fed by rock glaciers. This inventory will contribute to both the global inventory of rock glaciers and the ongoing effort in standardizing rock glacier inventories. 


\section{References}

Ackert, R.P., 1998, A rock glacier/debris-covered glacier system at Galena Creek, Absorka mountians, Wyoming: Geogr. Ann, v. 80, p. 267-276, https://about.jstor.org/terms.

Anderson, R.S., Anderson, L.S., Armstrong, W.H., Rossi, M.W., and Crump, S.E., 2018, Glaciation of alpine valleys: The glacier - debris-covered glacier - rock glacier continuum: Geomorphology, v. 311, p. 127-142, doi: 10.1016/j.geomorph.2018.03.015.

Arenson, L., Hoelzle, M., and Springman, S., 2002, Borehole deformation measurements and internal structure of some rock glaciers in Switzerland: Permafrost and Periglacial Processes, v. 13, p. 117-135, doi: 10.1002/ppp.414.

Azócar, G.F., and Brenning, A., 2010, Hydrological and geomorphological significance of rock glaciers in the dry Andes, Chile $\left(27^{\circ}-33^{\circ} \mathrm{s}\right)$ : Permafrost and Periglacial Processes, doi: 10.1002/ppp.669.

Ballantyne, C.K., 1987, Some observations on the morphology and sedimentology of two active protalus ramparts, Lyngen, northern Norway.: Arctic \& Alpine Research, v. 19, p. 167-174, doi: 10.2307/1551249.

Barcaza, G., Nussbaumer, S.U., Tapia, G., Valdés, J., García, J., Videla, Y., Albornoz, A., and Arias, V., 2017, Glacier inventory and recent glacier variations in the Andes of Chile, South America: Annals of Glaciology, v. 58, p. 166-180, doi: 10.1017/aog.2017.28.

Barsch, D., 1996, Rock glaciers: indicators for the present and former geoecology in high mountain environments: Berlin, Springer, $331 \mathrm{p}$.

Berthling, I., 2011, Beyond confusion: Rock glaciers as cryo-conditioned landforms: Geomorphology, v. 131, p. 98-106, doi: 10.1016/j.geomorph.2011.05.002.

Blagbrough, J.W., 1991, Late Pleistocene rock glaciers in the western part of the Capitan Mountains, Lincoln County, New Mexico: Description, age and climatic significance: New Mexico Geological Society Guidebook, v. 42, p. 333-338, http://nmgs.nmt.edu/publications/guidebooks/42.

Boulton, G.S., 1996, Theory of glacial erosion, transport and deposition as a consequence of subglacial sediment deformation: Journal of Glaciology, v. 42, p. 43-62, doi: $10.1017 / \mathrm{S} 0022143000030525$.

Brardinoni, F., Scotti, R., Sailer, R., and Mair, V., 2019, Evaluating sources of uncertainty and variability in rock glacier inventories: Earth Surface Processes and Landforms, doi: 10.1002/esp.4674. 
Brazier, V., Kirkbride, M.P., and Owens, I.F., 1998, The relationship between climate and rock glacier distribution in the Ben Ohau Range, New Zealand: Geografiska Annaler, Series A: Physical Geography, v. 80, p. 193-207, doi: 10.1111/j.04353676.1998.00037.x.

Brenning, A., 2005, Geomorphological, hydrological and climatic significance of rock glaciers in the Andes of Central Chile (33-35 $\mathrm{S}$ ): Permafrost and Periglacial Processes, v. 16, p. 231-240, doi: 10.1002/ppp.528.

Brenning, A., Grasser, M., and Friend, D.A., 2007, Statistical estimation and generalized additive modeling of rock glacier distribution in the San Juan Mountains, Colorado, United States: Journal of Geophysical Research: Earth Surface, v. 112, p. 1-10, doi: 10.1029/2006JF000528.

Burga, C.A., Frauenfelder, R., Ruffet, J., Hoelzle, M., and Kääb, A., 2004, Vegetation on Alpine rock glacier surfaces: A contribution to abundance and dynamics on extreme plant habitats: Flora, v. 199, p. 505-515, doi: 10.1078/0367-2530-00179.

Capps, S.R., 1910, Rock glaciers in Alaska: The Journal of Geology, v. 18, p. 359-375, http://www.journals.uchicago.edu/t-and-c.

Charbonneau, A.A., and Smith, D.J., 2018, An inventory of rock glaciers in the central British Columbia Coast Mountains, Canada, from high resolution Google Earth imagery: Arctic, Antarctic, and Alpine Research, v. 50, doi: 10.1080/15230430.2018.1489026.

Clark, D.H., Steig, E.J., Potter, N., Gillespie, A.R., Clark, D.H., Steig, E.J., Potter, N., and Gillespie, A.R., 1998, Genetic variability of rock glaciers: Geografiska Annaler, Series A: Physical Geography, v. 80, p. 175-182, doi: 10.1111/j.04353676.1998.00035.x.

Clow, D.W., Schrott, L., Webb, R., Campbell, D.H., Torizzo, A., and Dornblaser, M., 2003, Ground Water Occurrence and Contributions to Streamflow in an Alpine Catchment, Colorado Front Range: GroundWater, v. 41, p. 937-950, doi: 10.1111/j.1745-6584.2003.tb02436.x.

Cogley, J.G., Hock, R., Rasmussen, L.A., Arendt, A.A., Bauder, A., Braithwaite, R.J., Jansson, P., Kaser, G., M., M., Nicholson, L., and Zemp, M., 2011, Glossary of glacier mass balance and related terms: IHP=VII Technical Documents in Hydrology No. 86, IACS Contribution No. 2, UNESCO-IHP, Paris, v. 57.

Colombo, N., Salerno, F., Gruber, S., Freppaz, M., Williams, M., Fratianni, S., and Giardino, M., 2018, Review: Impacts of permafrost degradation on inorganic chemistry of surface fresh water: Global and Planetary Change, v. 162, p. 69-83, doi: 10.1016/j.gloplacha.2017.11.017. 
Colucci, R.R., Forte, E., Žebre, M., Maset, E., Zanettini, C., and Guglielmin, M., 2019, Is that a relict rock glacier? Geomorphology, v. 330, p. 177-189, doi: 10.1016/j.geomorph.2019.02.002.

Corte, A.E., 1987, Rock glacier taxonomy: London, Allen and Unwin, 27-39 p.

Crespo, S., Aranibar, J., Gomez, L., Schwikowski, M., Bruetsch, S., Cara, L., and Villalba, R., 2017, Ionic and stable isotope chemistry as indicators of water sources to the Upper Mendoza River basin, Central Andes of Argentina: Hydrological Sciences Journal, v. 62, p. 588-605, doi: 10.1080/02626667.2016.1252840.

Croce, F.A., and Milana, J.P., 2002, Internal structure and behaviour of a rock glacier in the arid Andes of Argentina: Permafrost and Periglacial Processes, v. 13, p. 289299, doi: 10.1002/ppp.431.

Cuffey, K.M. and Paterson, W.S.B., 2010, The physics of glaciers. Academic Press, 704 p.

Daly, C., Smith, J.W.J.I., Smith, J.W.J.I., and McKane, R.B., 2007, High-resolution spatial modeling of daily weather elements for a catchment in the Oregon Cascade Mountains, United States: Journal of Applied Meteorology and Climatology, v. 46, p. 1565-1586, doi: 10.1175/JAM2548.1.

Davis, R., and Walker, D., 1992, An upper-air synoptic climatology of the western United States: Journal of Climate, v. 5, p. 1449-1467.

Delaloye, R., and Echelard, T., 2020, IPA Action Group “ Rock glaciers inventories and ki nematics " Kick-off meeting:

Douglas, B., and Evans, D.J., 2010, Glaciers and glaciation: 2nd ed.London, Hodder Education, $801 \mathrm{p}$.

Duguay, M.A., Edmunds, A., Arenson, L.U., and Wainstein, P.A., 2015, Quantifying the significance of the hydrological contribution of a rock glacier - A review: GEOQuébec 2015. 68th Canadian Geotechnical Conference, 7th Canadian Permafrost Conference, p. CD-Rom.

Elconin, R.F., and LaChapelle, E.R., 1997, Flow and internal structure of a rock glacier: Journal of Glaciology, v. 43, p. 238-244, doi: 10.1017/S002214300000318X.

Esper Angillieri, M.Y., 2009, A preliminary inventory of rock glaciers at $30^{\circ} \mathrm{S}$ latitude, Cordillera Frontal of San Juan, Argentina: Quaternary International, v. 195, p. 151-157, doi: 10.1016/j.quaint.2008.06.001.

Falaschi, D., Castro, M., Masiokas, M., Tadono, T., and Ahumada, A.L., 2014, Rock glacier Inventory of the Valles Calchaquíes Region $\left(\sim 25^{\circ} \mathrm{S}\right)$, Salta, Argentina, 
derived from ALOS data: Permafrost and Periglacial Processes, v. 25, p. 69-75, doi: 10.1002/ppp. 1801.

Fegel, T.S., Baron, J.S., Fountain, A.G., Johnson, G.F., and Hall, E.K., 2016, The differing biogeochemical and microbial signatures of glaciers and rock glaciers: Journal of Geophysical Research: Biogeosciences, v. 121, p. 919-932, doi: 10.1002/2015JG003236.Received.

Florentine, C., Skidmore, M., Speece, M., Link, C., and Shaw, C.A., 2014, Geophysical analysis of transverse ridges and internal structure at Lone Peak Rock Glacier, Big Sky, Montana, USA: Journal of Glaciology, v. 60, p. 453-462, doi: 10.3189/2014JoG13J160.

Fountain, A.G., and Tangborn, W. V., 1985, The effect of glaciers on streamflow variations: Water Resources Research, v. 21, p. 579-586, doi: 10.1029/WR021i004p00579.

Fountain, A.G., Glenn, B., and Basagic, H.J., 2017, The geography of glaciers and perennial snowfields in the American West: Arctic, Antarctic, and Alpine Research, v. 49, p. 391-410, doi: 10.1657/AAAR0017-003.

Frehner, M., Ling, A.H.M., and Gärtner-Roer, I., 2015, Furrow-and-ridge morphology on rockglaciers explained by gravity-driven buckle folding: A case study from the murtèl rockglacier (Switzerland): Permafrost and Periglacial Processes, v. 26, p. 57-66, doi: 10.1002/ppp.1831.

Geiger, S.T., Daniels, J.M., Miller, S.N., and Nicholas, J.W., 2014, Influence of rock glaciers on stream hydrology in the La Sal Mountains, Utah: Arctic, Antarctic, and Alpine Research, v. 46, p. 645-658, doi: 10.1657/1938-4246-46.3.645.

Gobbi, M., Ballarin, F., Compostella, C., Lencioni, V., Seppi, R., Tampucci, D., and Caccianiga, M., 2014, Physical and biological features of an active rock glacier in the Italian Alps: Holocene, v. 24, p. 1624-1631, doi: 10.1177/0959683614544050.

Guglielmin, M., Camusso, M., Polesello, S., and Valsecchi, S., 2004, An old relict glacier body preserved in permafrost environment: The Foscagno rock glacier ice core (Upper Valtellina, Italian Central Alps): Arctic, Antarctic, and Alpine Research, v. 36, p. 108-116, doi: 10.1657/1523-0430(2004)036[0108:AORGBP]2.0.CO;2.

Haeberli, W., Hallet, B., Arenson, L., Elconin, R., Humlum, O., Kääb, A., Kaufmann, V., Ladanyi, B., Matsuoka, N., Springman, S., and Mühll, D.V., 2006, Permafrost creep and rock glacier dynamics: Permafrost and Periglacial Processes, doi: 10.1002/ppp.561. 
Haeberli, W., Zurich, H., and Haeberli, W., 1985, Creep of mountain permafrost: internal structure and flow of alpine rock glaciers: Eidgenössische Technische Hochschule Zürich, v. 77, 142 p.

Hafner, D.J., 1994, Pikas and permafrost: Post-Wisconsin historical zoogeography of Ochotona in the southern Rocky Mountains, USA: Arctic and Alpine Research, v. 26, p. 375-382, doi: 10.2307/1551799.

Hamilton, S.J., Whalley, W.B., and Whalley, B., 1995, Rock glacier nomenclature: A reassessment: Geomorphology, v. 14, p. 73-80.

Harrison, S., Whalley, B., and Anderson, E., 2008, Relict rock glaciers and protalus lobes in the British Isles: Implications for Late Pleistocene mountain geomorphology and palaeoclimate: Journal of Quaternary Science, v. 23, p. 287-304, doi: 10.1002/jqs. 1148 .

Hausmann, H., Krainer, K., Bruckl, E., and Mostler, W., 2007, Internal structure and ice content of Reichenkar rock glacier (Stubai Alps, Austria) accessed by geophysical investigations: Permafrost and Periglacial Processes, v. 18, p. 351-367, doi: 10.1002/ppp.601.

Hausmann, H., Krainer, K., Brückl, E., and Ullrich, C., 2012, Internal structure, ice content and dynamics of Ölgrube and kaiserberg rock glaciers (Ötztal Alps, Austria) determined from geophysical surveys: Austrian Journal of Earth Sciences, v. 105, p. 12-31.

Hedding, D.W., 2011, Pronival rampart and protalus rampart: A review of terminology: Journal of Glaciology, v. 57, p. 1179-1180, doi: 10.3189/002214311798843241.

Horton, J. D., 2017, The State Geologic Map Compilation (SGMC) geodatabase of the conterminous United States.

Humlum, O., 1988, Rock glacier appearance level and rock glacier initiation line altitude: a methodological approach to the study of rock glaciers: Arctic \& Alpine Research, v. 20, p. 160-178, doi: 10.2307/1551495.

Humlum, O., 2000, The geomorphic significance of rock glaciers: Estimates of rock glacier debris volumes and headwall recession rates in West Greenland: Geomorphology, v. 35, p. 41-67, doi: 10.1016/S0169-555X(00)00022-2.

Ikeda, A., and Matsuoka, N., 2006, Pebbly versus bouldery rock glaciers: Morphology, structure and processes: Geomorphology, v. 73, p. 279-296, doi: 10.1016/j.geomorph.2005.07.015.

Janke, J., and Frauenfelder, R., 2008, The relationship between rock glacier and contributing area parameters in the Front Range of Colorado: Journal of Quaternary Science, v. 23, p. 153-163, doi: 10.1002/jqs.1133. 
Janke, J.R., 2007, Colorado front range rock glaciers: distribution and topographic characteristics: Arctic, Antarctic, and Alpine Research, v. 39, p. 74-83, doi: 10.1657/1523-0430(2007)39[74:CFRRGD]2.0.CO;2.

Janke, J.R., Bellisario, A.C., and Ferrando, F.A., 2015, Classification of debris-covered glaciers and rock glaciers in the Andes of central Chile: Geomorphology, v. 241, p. 98-121, doi: 10.1016/j.geomorph.2015.03.034.

Johnson, B.G., Thackray, G.D., and Van Kirk, R., 2007, The effect of topography, latitude, and lithology on rock glacier distribution in the Lemhi Range, central Idaho, USA: Geomorphology, v. 91, p. 38-50, doi: 10.1016/j.geomorph.2007.01.023.

Johnson, G., 2018, Rock glaciers of the contiguous United States: Spatial distribution, cryospheric context, and riparian vegitation [PhD thesis]: , p. 147.

Jones, D.B., Harrison, S., Anderson, K., and Betts, R.A., 2018, Mountain rock glaciers contain globally significant water stores: Scientific Reports, v. 8, p. 1-10, doi: 10.1038/s41598-018-21244-w.

Jones, D.B., Harrison, S., Anderson, K., and Whalley, W.B., 2019, Earth-Science Reviews Rock glaciers and mountain hydrology : A review: v. 193, p. 66-90, doi: 10.1016/j.earscirev.2019.04.001.

Jones, D.B., Harrison, S., Anderson, K., Selley, H.L., Wood, J.L., and Betts, R.A., 2018, The distribution and hydrological significance of rock glaciers in the Nepalese Himalaya: Global and Planetary Change, v. 160, p. 123-142, doi: 10.1016/j.gloplacha.2017.11.005.

Kääb, A., and Weber, M., 2004, Development of transverse ridges on rock glaciers: Field measurements and laboratory experiments: Permafrost and Periglacial Processes, v. 15, p. 379-391, doi: 10.1002/ppp.506.

Kellerer-Pirklbauer, A., 2016, Monitoring nourishment processes in the rooting zone of an active rock glacier in an alpine environment: Zeitschrift fur Geomorphologie, Supplementary Issues, v. 60, p. 99-121.

Kenner, R., and Magnusson, J., 2017, Estimating the Effect of Different Influencing Factors on Rock Glacier Development in Two Regions in the Swiss Alps: Permafrost and Periglacial Processes, v. 28, p. 195-208, doi: 10.1002/ppp.1910.

Kerschner, H., 1978, Paleoclimatic inferences from Late Wurm rock glaciers, Eastern Central Alps, Western Tyrol, Austria: Arctic and Alpine Research, v. 10, p. 635, doi: $10.2307 / 1550684$.

Kinworthy, B., 2016, New mexico rock glacier inventory: analysis of geomorphology and paleogeography [MS thesis]: The University of New Mexico, 124 p. 
Krainer, K., and Ribis, M., 2012, A rock glacier inventory of the tyrolean alps (Austria): Austrian Journal of Earth Sciences, v. 105, p. 32-47, doi: 10.1016/B978-0-12417013-1.00007-8.

Legg, B.N., 2016, Rock glacier morphology and morphometry in glacier national park, northwest Montana, USA [MS thesis]: Texas State University, 64 p.

Leonard, K.C., and Fountain, A.G., 2003, Map-based methods for estimating glacier equilibrium-line altitudes: Journal of Glaciology, v. 49, p. 329-336, doi: $10.3189 / 172756503781830665$.

Leopold, M., Williams, M.W., Caine, N., Völkel, J., and Dethier, D., 2011, Internal structure of the Green Lake 5 rock glacier, Colorado Front Range, USA: Permafrost and Periglacial Processes, v. 22, p. 107-119, doi: 10.1002/ppp.706.

Lilleøren, K.S., and Etzelmüller, B., 2011, A regional inventory of rock glaciers and icecored moraines in Norway: Geografiska Annaler, Series A: Physical Geography, v. 93, p. 175-191, doi: 10.1111/j.1468-0459.2011.00430.x.

Liu, L., Millar, C.I., Westfall, R.D., and Zebker, H.A., 2013, Surface motion of active rock glaciers in the Sierra Nevada, California, USA: Inventory and a case study using InSAR: Cryosphere, v. 7, p. 1109-1119, doi: 10.5194/tc-7-1109-2013.

Lugon, R., and Stoffel, M., 2010, Rock-glacier dynamics and magnitude-frequency relations of debris flows in a high-elevation watershed: Ritigraben, Swiss Alps: Global and Planetary Change, v. 73, p. 202-210, doi:

10.1016/j.gloplacha.2010.06.004.

Martin, H.E., and Whalley, W.B., 1987, Rock glacierse: part 1: rock glacier morphology: classificatoin and distribution: Progress in Physical Geography, v. 11, p. 260-282.

Meier, M.F., 1984, Contribution of small glaciers to global sea level: Science, v. 226, p. 1418-1421.

Millar, C.I., and Westfall, R.D., 2008, Rock glaciers and related periglacial landforms in the Sierra Nevada, CA, USA; inventory, distribution and climatic relationships: Quaternary International, v. 188, p. 90-104, doi: 10.1016/j.quaint.2007.06.004.

Millar, C.I., and Westfall, R.D., 2010, Distribution and climatic relationships of the american pika (Ochotona princeps) in the sierra Nevada and western great basin, U.S.A.; Periglacial landforms as refugia in warming climates: Arctic, Antarctic, and Alpine Research, v. 42, p. 76-88, doi: 10.1657/1938-4246-42.1.76.

Millar, C.I., and Westfall, R.D., 2019, Geographic, hydrological, and climatic significance of rock glaciers in the Great Basin, USA: Arctic, Antarctic, and Alpine Research, v. 51, p. 232-249, doi: 10.1080/15230430.2019.1618666. 
Mitchell, V.L., 1976, Regionalization of Climate in the Western United States.: Journal of Applied Meteorology, v. 15, p. 920-927, doi: 10.1175/15200450(1976)015<0920:TROCIT>2.0.CO;2.

Monnier, S., and Kinnard, C., 2013, Internal structure and composition of a rock glacier in the Andes ( upper Choapa valley, Chile ) using borehole information and ground-penetrating radar: Annals of Glaciology, v. 54, p. 61-72, doi: 10.3189/2013AoG64A107.

Monnier, S., and Kinnard, C., 2015, Reconsidering the glacier to rock glacier transformation problem: new insights from the central Andes of Chile: Geomorphology, v. 238, p. 47-55, doi: 10.1016/j.geomorph.2015.02.025.

Moore, R.D., Fleming, S.W., Menounos, B., Wheate, R., Fountain, A., Stahl, K., Holm, K., and Jakob, M., 2009, Glacier change in western North America: influences on hydrology, geomorphic hazards and water quality: Hydrological Processes, v. 23, p. 42-61, doi: 10.1002/hyp.

Morris, S.E., 1981, Topoclimatic factors and the development of rock glacier facies, Sangre de Cristo mountains, southern Colorado.: Arctic and Alpine Research, v. 13, p. 329-338, doi: 10.2307/1551039.

Müller, J., Vieli, A., and Gärtner-Roer, I., 2016, Rock glaciers on the run - Understanding rock glacier landform evolution and recent changes from numerical flow modeling: Cryosphere, v. 10, p. 2865-2886, doi: 10.5194/tc-10-2865-2016.

Munroe, J.S., 2018, Distribution, evidence for internal ice, and possible hydrologic significance of rock glaciers in the Uinta Mountains, Utah, USA: Quaternary Research (United States), v. 90, p. 50-65, doi: 10.1017/qua.2018.24.

Petersen, E.I., Holt, J.. W., Stuurman, C.. M., Levy, J.. S., Nerozzi, S., Paine, J.. G., Larsen, C.. F., Fahnestock, M., Peterson, E.., Holt, J.. W., Stuurman, C.. M., Levy, J.. S., Nerozzi, S., Paine, J.. G., et al., 2016, Sourdough Rock Glacier: Alaska: An analog to Martian debris-covered glaciers: Lunar and Planetary Science Conference XLVII, p. 46-47, doi: 10.1038/ngeo2474.

Potter, N., 1972, Ice-cored rock glacier, Galena Creek, Northern Absaroka Mountains, Wyoming: Geographical Information Systems: Principles and Applications, v. 83, p. 3025-3058.

Potter, N., Steig, E.J., Clark, D.H., Speece, M.A., Clark, G.M., and Updike, A.B., 1998, Galena Creek rock glacier revisited-new observations on an old controversy: Geografiska Annaler, Series A: Physical Geography, v. 80, p. 251-265.

Radić, V., Bliss, A., Beedlow, A.C., Hock, R., Miles, E., and Cogley, J.G., 2014, Regional and global projections of twenty-first century glacier mass changes in 
response to climate scenarios from global climate models: Climate Dynamics, v. 42, p. 37-58, doi: 10.1007/s00382-013-1719-7.

Rangecroft, S., Harrison, S., and Anderson, K., 2015, Rock Glaciers as water stores in the Bolivian Andes: An assessment of their hydrological importance: Arctic, Antarctic, and Alpine Research, v. 47, p. 89-98, doi: 10.1657/AAAR0014-029.

Rangecroft, S., Harrison, S., Anderson, K., Magrath, J., Castel, A.P., and Pacheco, P., 2014, A first rock glacier inventory for the Bolivian Andes: Permafrost and Periglacial Processes, v. 25, p. 333-343, doi: 10.1002/ppp. 1816.

Refsnider, K.A., and Brugger, K.A., 2007, Rock glaciers in central Colorado, U.S.A., as indicators of Holocene climate change: Arctic, Antarctic, and Alpine Research, v. 39, p. 127-136, doi: 10.1657/1523-0430(2007)39[127:RGICCU]2.0.CO;2.

Reheis, M., 1975, Source, transport and depostion of debris on Arapaho glacier, Front Range, Colorado, U.S.A: Journal of Glaciology, v. 14, p. 407-420.

Riffle, A., 2018, Internal composition, structure, and hydrological significance of rock glaciers in the Eastern Cascades, Washington: , p. 156.

Roer, I., Haeberli, W., Avian, M., Kaufmann, V., Delaloye, R., Lambiel, C., and Kääb, A., 2008, Observations and considerations on destabilizing active rock glaciers in the European Alps: Ninth international conference on Permafrost, p. 1505-1510, doi: $10.5167 /$ uzh-6082.

Scapozza, C., Lambiel, C., Baron, L., Marescot, L., and Reynard, E., 2011, Internal structure and permafrost distribution in two alpine periglacial talus slopes, Valais, Swiss Alps: Geomorphology, v. 132, p. 208-221, doi:

10.1016/j.geomorph.2011.05.010.

Scotti, R., Brardinoni, F., Alberti, S., Frattini, P., and Crosta, G.B., 2013, A regional inventory of rock glaciers and protalus ramparts in the central Italian Alps: Geomorphology, v. 186, p. 136-149, doi: 10.1016/j.geomorph.2012.12.028.

Seligman, Z.M., 2009, Rock-glacier distribution, activity, and movement, northern Absaroka and Beartooth Ranges [MS thesis]: The University of Montana, $57 \mathrm{p}$.

Serrano, E., San José, J.J., and Agudo, C., 2006, Rock glacier dynamics in a marginal periglacial high mountain environment: Flow, movement (1991-2000) and structure of the Argualas rock glacier, the Pyrenees: Geomorphology, v. 74, p. 285-296, doi: 10.1016/j.geomorph.2005.08.014.

Shroder, J.F., Bishop, M.P., Copland, L., and Sloan, V.F., 2000, Debris-covered glaciers and rock glaciers in the Nanga Parbat Himalaya, Pakistan: Geografiska Annaler, Series A: Physical Geography, v. 82, p. 17-31, doi: 10.1111/j.0435-

3676.2000.00108.x. 
Thies, H., Nickus, U., Tolotti, M., Tessadri, R., and Krainer, K., 2013, Evidence of rock glacier melt impacts on water chemistry and diatoms in high mountain streams: Cold Regions Science and Technology, v. 96, p. 77-85, doi: 10.1016/j.coldregions.2013.06.006.

Thompson, W.., 1962, Preliminary notes on the nature and distribution of rock glaciers relative to true glaciers and other effects of the climate on the ground in North America: In Symposium at obergurl, v. 58, p. 212-219.

U.S. Geological Survey, 2017, 1/3rd arc-second Digital Elevation Models (DEMs) USGS National Map 3DEP Downloadable Data Collection: U.S. Geological Survey:, https://www.sciencebase.gov/catalog/item/4f70aa9fe4b058caae3f8de5\%0Ahttps:/ /viewer.nationalmap.gov/basic/\#startUp.

Uxa, T., and Mida, P., 2017, Rock glaciers in the western and high tatra mountains, western carpathians: Journal of Maps, v. 13, p. 844-857, doi: 10.1080/17445647.2017.1378136.

Van Hoesen, J.G., and Orndorff, R.L., 2011, The morphology and spatial distribution of late Quaternary periglacial landforms, Snake Range, Nevada: A gis-based approach to prioritizing field sites: Source: Journal of the Arizona-Nevada Academy of Science, v. 43, p. 48-60.

Wahrhaftig, C., and Cox, A., 1959, Rock glaciers in the Alaska range: Bull. Geol. Soc. America, v. 70, p. 383-436, https://pubs.geoscienceworld.org/gsa/gsabulletin/articlepdf/70/4/383/3431816/10016-7606-70-4-383.pdf.

Whalley, W.B., and Azizi, F., 2003, Rock glaciers and protalus landforms: Analogous forms and ice sources on Earth and Mars: Journal of Geophysical Research, v. 108, p. 1-17, doi: 10.1029/2002JE001864.

Williams, M.W., Knauf, M., Caine, N., Liu, F., and Verplanck, P.L., 2006, Geochemistry and source waters of rock glacier outflow, Colorado Front Range: Permafrost and Periglacial Processes, doi: 10.1002/ppp.535.

Winberry, J.P., Anandakrishnan, S., Wiens, D.A., Alley, R.B., and Christianson, K., 2011, Dynamics of stick-slip motion, Whillans Ice Stream, Antarctica: Earth and Planetary Science Letters, v. 305, p. 283-289, doi: 10.1016/j.eps 


\section{Appendix A Classification Change}

My initial classification categorized rock glaciers into four groups: active, inactive, relict, and feature of interest (Table A-2). Active rock glaciers contain internal ice and move, inactive contain some internal ice but no longer move, and relict no longer moves or contain internal ice. The classification was tested against actively moving rock glaciers found by Liu et al. (2013) in which they examined 59 'rock glaciers' for the movement in the Sierra Nevada Range of California using interferometric synthetic aperture radar (InSAR). All 59 'rock glaciers' were found to be moving therefore all of them are rock glaciers. Millar and Westfall (2019) tried to define morphological traits of the 59 rock glaciers that could be used to infer movement and found no single diagnostic characteristics. Instead, they found a number of characteristics that may be present in various combinations. They include, "steep front and side angles, unweathered boulders, large boulders pitched at the crest of the fronts and sides, fine sediment on the fronts below the crest, steep-crested furrows on the surface, high elevation and cold aspect, sparse or no vegetation on the feature, springs, tarns, and/or wetland below the front-if tarns, water may contain suspended sediments and appear aquamarine in color, and associated persistent ice fields above the feature or thermokarsts revealing ice on the surface." I independently classified the 59 rock glaciers most of which were 'active' or 'inactive’ (Table A-1, Figure A-1). 

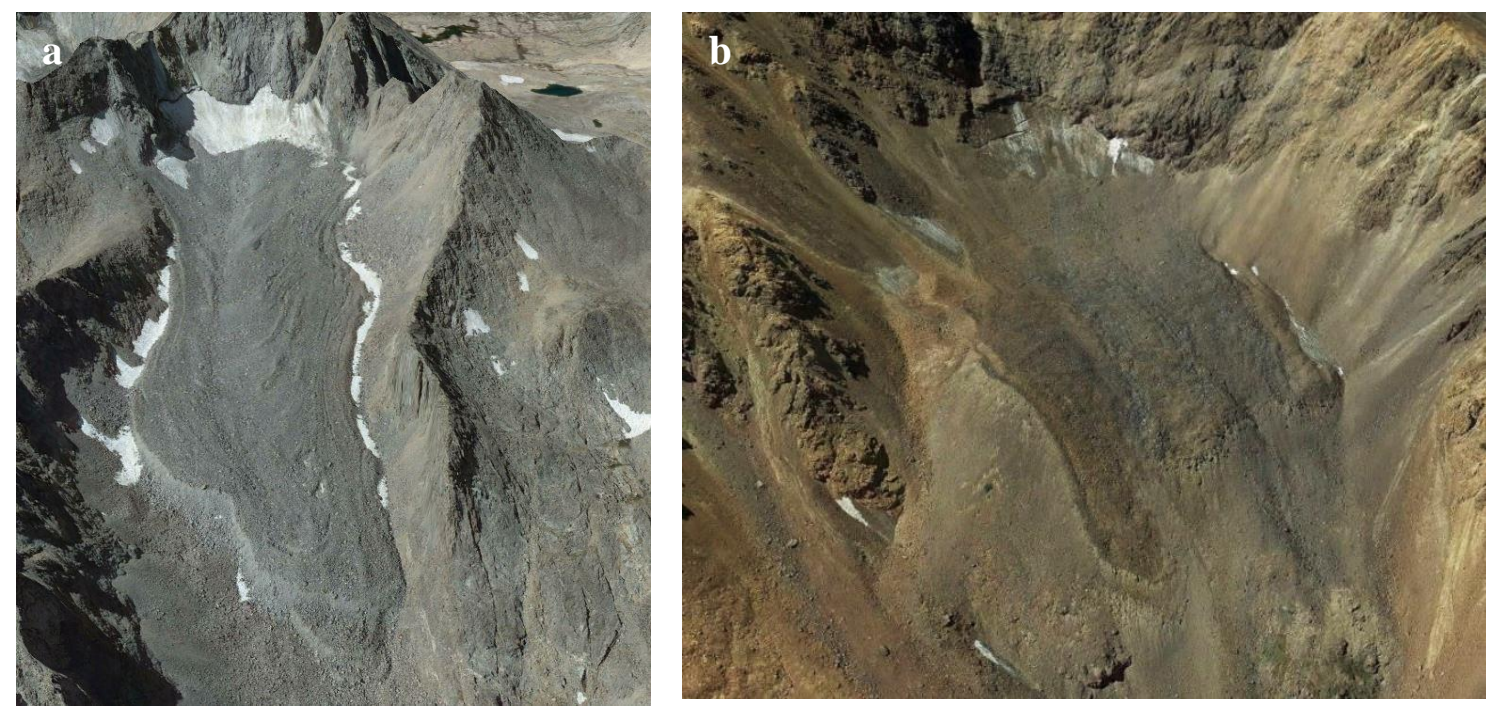

Figure A-1: Examples of moving rock glaciers identified by Liu et al.,(2013), a) a rock glacier I initially classified as active (Sierra Nevada Range, California, -118.524 , $37.11803^{\circ}$ ); b) a rock glacier I initially classified as inactive (Sierra Nevada Range, California, $-119.3028^{\circ}, 38.02894^{\circ}$ ). Image source: Google Earth Pro.

Table A-1: My initial and updated reinterpretation of previous rock glacier inventory (Liu et al. 2013) for the Sierra Nevada Range, California. Features not classified as rock glaciers become a 'Feature of Interest'. The number in the 'Initial' row indicates my initial reclassification. The 'Updated' row indicated my updated reclassification. All of Liu's imaged features are moving.

\begin{tabular}{rrrrr} 
& \multicolumn{2}{c}{ Rock Glaciers } & \multicolumn{2}{c}{ Feature of } \\
& Active & Inactive & Relict & Interest \\
\cline { 2 - 5 } Initial & 27 & 29 & 2 & 1 \\
Updated & 58 & 1 & 0 & 0
\end{tabular}

Based on these results it was clear that my assessment of active and inactive was inaccurate and combined to "active" (Table A-3). Relict was renamed "inactive", and features of interest remained unchanged. I conjecture that inactive rock glaciers may still contain ice but are no longer moving. Other inventories also combined their active and inactive categories calling it 'intact' because they both contain ice, and have a relict/ fossil category for rock glaciers that are not moving and do not contain ice (Charbonneau 
and Smith, 2018; Lilleøren and Etzelmüller, 2011; Azócar and Brenning, 2010; Krainer and Ribis, 2012; Cremonese et al., 2011; Kellerer-Pirklbauer et al., 2012).

The new scheme, partially based on the IPA action group: rock glacier inventories and kinematics scheme was a major influence (Delaloye and Echelard, 2020) is much simplified. My final classification scheme consists of two categories, active and inactive rock glaciers. Active rock glaciers contain ice and are moving, and inactive may contain ice and are no longer moving. Their characteristics were made into categories and subcategories. The main characteristics seen in the field are that they extend into the valley, has over steepened lower margins, and exhibit positive relief. They can also exhibit ridge and furrow topography and have vegetation of the surface. Vegetation on rock glaciers has been used to distinguish between active and relict cases (Lilleoren and Etzelmuller, 2011; Krainer and Ribbs, 2012; Riffle, 2018). However, some vegetation appears on active rock glaciers (Uxa and Mida, 2017). There was little vegetation on the rock glaciers examined by Liu et al., (2013) because there is little alpine vegetation in the region. Bollmann et al. (2015) found that out of ten rock glaciers that are classified as relict, four, which also had some vegetation cover, were moving. Vegetation on rock glaciers may depend on the grain size of the debris (Burga et al., 2004; Gobbi et al., 2014). Vegetation tends to decrease in the more unstable areas, where there is more significant movement, and coarser-grained material (Burga et al., 2004). Vegetation is seen in small pockets of fine-grained material where the surface has reached sufficient stability for it to grow (Cannone and Gerdol, 2003). 
To test my new classification scheme, I examined 14 aerial photos of known active rock glaciers (Table A-4). Most of the rock glaciers examined, 71\% (10), support my new classification scheme; however, 29\% (4) did not (Table A-4). The rock glaciers that did not support my revised classification are the Sourdough, Galena Creek, Lone Peak, and Pietrele rock glaciers (Table A-4c,d). These rock glaciers have all of the characteristics of active rock glaciers but have vegetation on the surface.
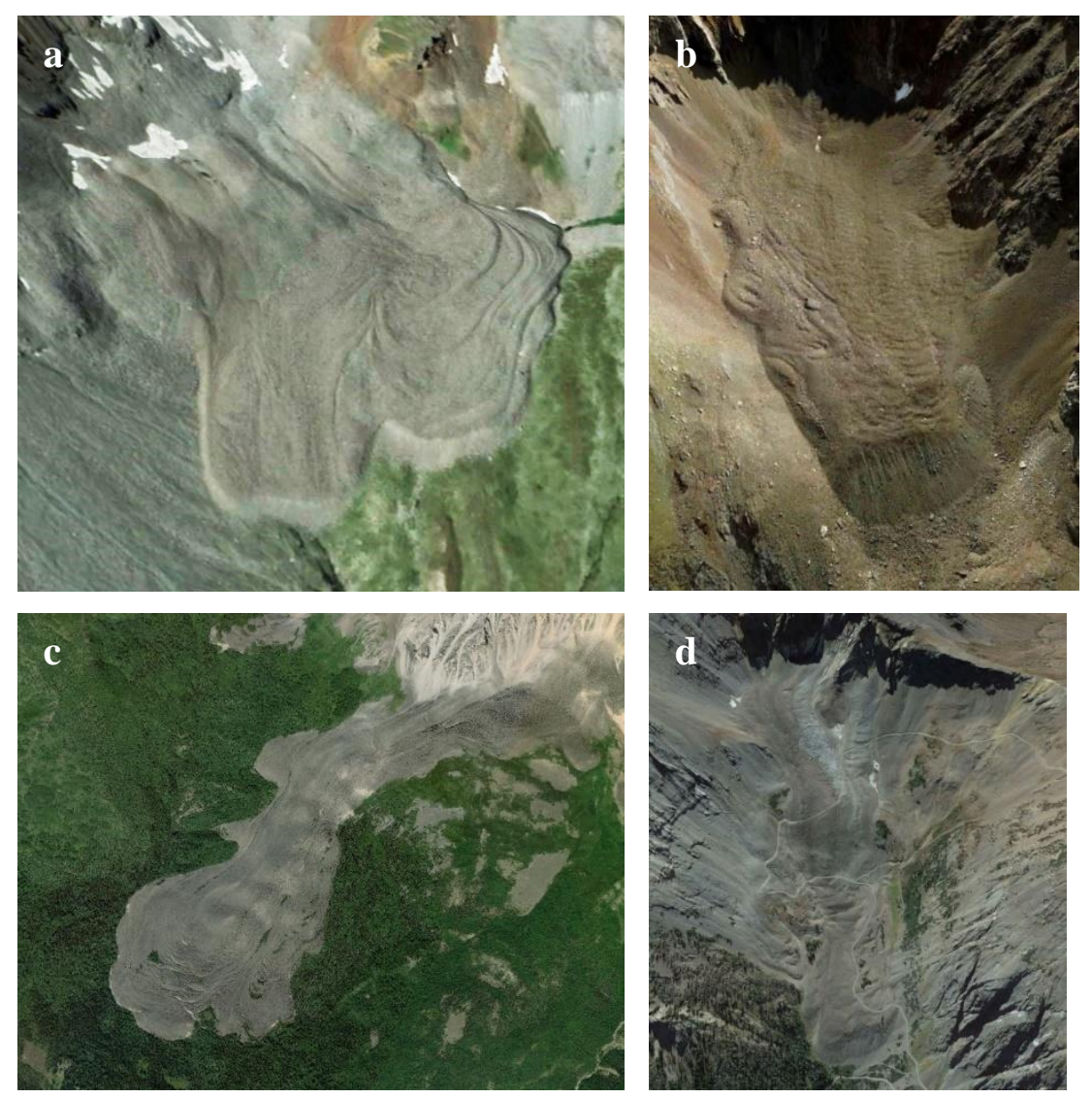

Figure A-2: Top row showing rock glaciers that support my re-classification, (a) Kaiserberg rock glacier, Austrian Alps (46.910724 $\left.4^{\circ}, 10.6778167^{\circ}\right)$; (b) Argualas rock glacier, Pyrenees Mountains, Spain $\left(42.774201^{\circ},-0.272852^{\circ}\right.$ ). Bottom row shows rock glaciers that initially didn't support my reclassification, (c) the Sourdough rock glacier, St. Elias Mountains, Alaska ($\left.142.741^{\circ}, 61.395^{\circ}\right)$; (d) Galena Creek rock glacier, Absaroka mountains Wyoming $\left(-109.7916^{\circ}, 44.64418^{\circ}\right)$. Image source: Google Earth Pro and ArcMap. 
Table A-2: The original rock glacier classification scheme.

\section{Active}

Margins are sharply defined by steep/over-steepened terminal front and sides (an indicator of ice binding rock together)

Ridges and furrows are often arcuate and convex downslope (an indicator of internal deformation)

Typically, vegetation-free (an indicator of movement)

Lobate - valley wall

$$
\text { Lobate - valley wall }
$$

Single or multiple lobes extending out from the bases of talus slopes

Wider than long

Tongue - valley floor

Longer than wide

Can completely fill cirques and occupies the axis of a valley

Water pooling on the surface (an indicator of ice)

\section{Inactive}

Margins are defined by steep terminal front and sides (an indicator of ice-binding rock together)

Dominantly smooth surface which lacks distinct ridges and furrows (an indicator of no internal deformation)

Vegetation on the surface (an indicator of no movement)

Lobate - valley wall

Extends out from the bases of talus slopes

Wider than long

Tongue - Valley floor

Longer than wide

Can completely fill cirques and occupies the axis of a valley

Surface erosion evident creating gully-like features

Water pooling on the surface (an indicator of ice)

\section{Relict}

Margins are defined by gentler terminal front and sides (an indicator of lack of ice)

More subdued ridges and furrows or a flat surface (indicator or no internal deformation)

Vegetation on terminal fronts and elsewhere (an indicator of lack of movement)

Collapse structures on the surface (depressions, conical pits)

Portions of the surface are deflated

\section{Features of Interest}

Margins are defined by steep terminal front and sides

Can be a ridge or series of ridges parallel to the valley wall

Usually wider than they are long 
Table A-3: My initial and revised classification of Liu et al. 2013 rock glacier inventory. The columns 'Name' and 'Speed' are from Liu et al. (2013). The 'Initial' column represents my initial classification of the rock glaciers, and the 'Updated' column is my revised classification.

\section{Name}

Mt Patterson

RobinsonCr-CattleCr

GreenCr-EastFk3

LundyCyn-BurroLk-

MtExcelsior1

LundyCyn-DoreCliffs 2

LundyCyn-DoreCliffs 3

LeeViningCr-KarolynCyn7

Mount Gibbs

ParkerCyn7

ConvictCyn2A

Red and White Mtn

Mt Hopkins

Mt Mills

Recess Pk1

Recess Pk2

Bear Ck Spire

Elderberry Cyn

Mt Tom

Four Gables

Four Gables-Upper Horton Lk

Mt Humphreys-Longley Lk

Mt Humphreys

Blackcap Mtn

PiuteCr-Glacier-Divide4

PiuteCr-Glacier-Divide5

PiuteCr-GoetheGlacier1A

Sky High Lk

Mt Lamarck-Wishbone Lk

Mt Mendel-Darwin Cyn

Mt Powel

Mt Thompson-Sunset Lk

Mt Thompson 1

Mt Thompson 2
Longitude Latitude

$-119.28$

$-119.35$

$-119.31$

$-119.3$

$-119.27$

$-119.27$

$-119.22$

$-119.2$

$-119.21$

$-118.86$

$-118.85$

$-118.81$

$-118.79$

$-118.87$

$-118.86$

$-118.76$

$-118.65$

$-118.65$

$-118.7$

$-118.68$

$-118.67$

$-118.66$

$-118.78$

$-118.74$

$-118.75$

$-118.71$

$-118.67$

$-118.67$

$-118.68$

$-118.63$

$-118.62$

$-118.6$

$-118.6$
38.4289

38.0915

38.0377

38.029

37.9979

37.9977

37.9265

37.8948

37.8187

37.51

37.4853

37.4681

37.4011

37.3965

37.3876

37.3623

37.355

37.3464

37.3113

37.2997

37.2771

37.2647

37.2422

37.2286

37.2272

37.212

37.2045

37.2015

37.1816

37.1464

37.1451

37.1435

37.1439

\section{Speed Initial Updated
$(\mathrm{cm} / \mathrm{yr})$}

24.7 Inactive Active

48.9 Active Active

36.6 Active Active

34.6 Inactive Active

32.9 Relict Inactive

43.1 Active Active

35.5 Active Active

43 Active Active

38.7 Inactive Active

48.2 Active Active

47.8 Inactive Active

64.5 Inactive Active

59 Active Active

62.2 Inactive Active

36.6 Relict Active

48.6 Inactive Active

16.8 Inactive Active

71.2 Active Active

71.3 Inactive Active

62.2 Active Active

75.5 Inactive Active

62.8 Active Active

50.3 Inactive Active

54.3 Inactive Active

47.7 Inactive Active

59.6 Inactive Active

37.1 Inactive Active

68.7 Inactive Active

60.4 Active Active

87 Active Active

34.7 Inactive Active

38.8 Inactive Active

56.2 Inactive Active 


\begin{tabular}{lrrrll} 
Mt Johnson & -118.58 & 37.1326 & 46.3 & Inactive & Active \\
Mt Agassiz & -118.52 & 37.118 & 83.5 & Active & Active \\
BigPineCr-SouthFk1 & -118.45 & 37.0783 & 57.1 & Active & Active \\
Birch Mtn-Birth Lk & -118.43 & 37.0636 & 44.7 & Active & Active \\
Mt Bolton Brown 1 & -118.43 & 37.0504 & 14.1 & Inactive & Active \\
Mt Bolton Brown 2 & -118.43 & 37.0446 & 36.6 & Inactive & Active \\
Mt Bolton Brown-Tinemaha & & & & & \\
Lk & -118.43 & 37.0396 & 36.8 & Active & Active \\
Split Mtn & -118.42 & 37.0339 & 66.4 & Active & Active \\
Cardinal Mtn 1 & -118.41 & 37.0113 & 61.3 & Active & Active \\
Cardinal Mtn 2 & -118.41 & 37.0071 & 67.3 & Active & Active \\
Vennacher Needle-Kings Rr & -118.47 & 37.0045 & 41.4 & Active & Active \\
Mt Perkins & -118.37 & 36.9243 & 60.7 & Inactive & Active \\
Acrodectes Pk-Stocking Lk & -118.37 & 36.8647 & 50 & Active & Active \\
Dimond Pk & -118.39 & 36.8302 & 59 & Inactive & Active \\
Mt Gardiner-Gardiner Lks & -118.45 & 36.8042 & 55.5 & Inactive & Active \\
Deerhorn Mtn & -118.39 & 36.7136 & 66.5 & Inactive & Active \\
Mt Stanford 1 & -118.39 & 36.7048 & 74.6 & Active & Active \\
Mt Stanford 2 & -118.38 & 36.7016 & 68.4 & Active & Active \\
Ericsson Crags & -118.41 & 36.7016 & 66.5 & Active & Active \\
Table Mtn & -118.48 & 36.6622 & 64.7 & Inactive & Active \\
Mt Barnard & -118.3 & 36.6242 & 50.5 & Active & Active \\
Vacation Pass-Tunnabora Pk & -118.29 & 36.6093 & 60.8 & Active & Active \\
Mt Hale & -118.31 & 36.59 & 64.1 & Inactive & Active \\
Mt McAdie-Consulation Lk & -118.27 & 36.557 & 55 & Active & Active \\
Kaweah Pks Range 1 & -118.51 & 36.5587 & 45.5 & Inactive & Active \\
Kaweah Pks Range 2 & -118.48 & 36.5352 & 73.2 & Inactive & Active \\
& & & & & \\
\hline
\end{tabular}


Table A-4: My initial and revised classifications of known active rock glaciers. The columns 'Name' and 'Speed' are from the study listed in the 'Source' column. The 'Initial' column represents my initial reclassification of the rock glaciers, and the 'Final' column in my revised reclassification scheme.

\begin{tabular}{rrrcrr} 
Rock Glacier & Location & Initial & Final & $\begin{array}{r}\text { Speed } \\
(\mathbf{c m} / \mathbf{y r})\end{array}$ & Source \\
\hline Arapaho & Colorado & Active & Active & 19.3 & Benedict et al., 1986 \\
Reichenkar & Austria & Active & Active & $255-365$ & Krainer and Mostler, 2006 \\
Kaiserberg & Austria & Active & Active & 73000 & Krainer and Mostler, 2006 \\
Olgrube & Austria & Active & Active & $76-229$ & Krainer and Mostler, 2006 \\
Argualas & Pyrenees & Active & Active & $1.4-56.2$ & Kääb et al., 2003 \\
Nautardalur & Iceland & Active & Active & 25 & Whalley et al., 1995 \\
Sourdough & Alaska & Relict & Active & 200 & Petersen et al., 2016 \\
Galena Creek & Wyoming & Relict & Active & $6.5-80$ & Potter et al., 1998 \\
Lone Peak & Montana & Relict & Active & $16-20$ & Florentine et al., 2014 \\
Hilda & Canada & Active & Active & 1.6 & Bachrach et al., 2004 \\
Laurichard & France & Active & Active & $39-144$ & Bodin et al., 2009 \\
Kings Throne & Canada & Active & Active & $29.1-59.1$ & Koning and Smith, 1999 \\
Hinteres & & & & & Kaufmann and Ladstädter, \\
Langtalkar & Austria & Active & Active & 135 & \\
Pietrele & Romania & Relict & Active & $0.8-2.2$ & Necsoiu et al., 2016
\end{tabular}




\section{Appendix B Comparisons with Regional Inventories}

\section{Comparison with Florentine's (2011) rock glacier inventory of southwest Montana and northeast Wyoming}

Florentine, C., 2011, Regional context, internal structure, and microbiological investigation of the Lone Peak rock glacier, Big Sky, Montana [MS thesis]: Montana State University, 77 p., doi: 10.1080/01402390.2011.569130.

Florentine (2011) inventoried rock glaciers in the Beartooth Plateau, and the Absaroka, Gallatin, and Madison ranges of southwest Montana as well as the Bighorn Mountains of Wyoming using Google Earth and ArcGIS (Figure B-1). The characteristics she used to identify rock glaciers include "talus-fed, lobate in shape, bordered by steep margins, and originating above the tree-line (2000 m)". Morphological indications of movement and ice content were not considered, and she did not subclassify her rock glaciers.

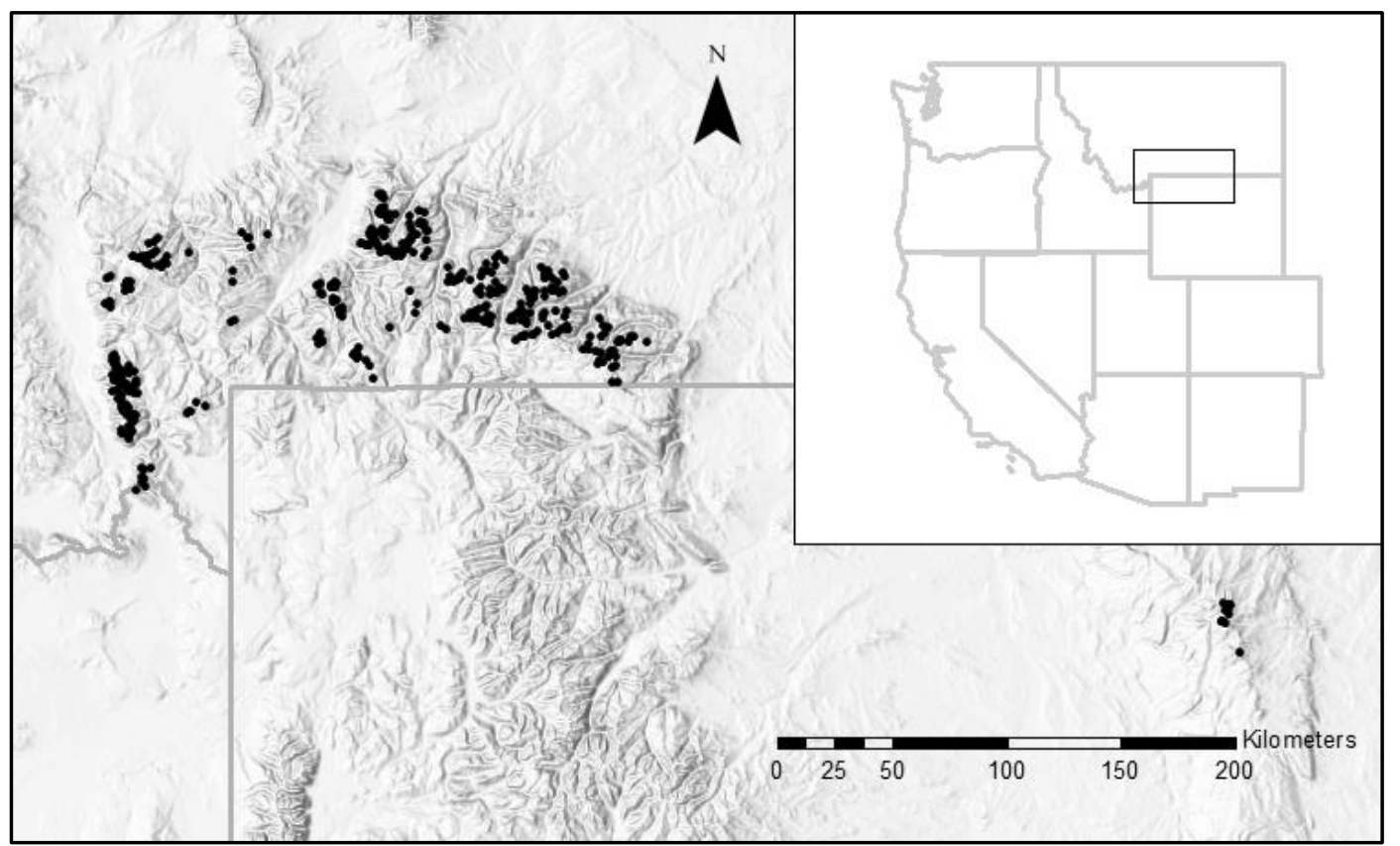

Figure B-1: The Florentine (2011) rock glacier inventory (filled circles) on a shaded relief map. 
She identified 404 features as rock glaciers compared to Johnson's (2018) 697;

266 features were common to both (Table B-1). My re-examination of all 835 features identifies 220 rock glaciers, 526 features of interest, and 89 features eliminated (Table B-2). I found 15 rock glaciers not included in either inventory and added 7 features of interest (FOI).

Table B-1: The number of features identified as rock glaciers in Florentine's (2011) and Johnson's (2018) inventories. Features that are included in only one inventory are Unique, those that are common to both inventories are Overlap, and Duplicates are those features that have two location points, suggesting double counting.

\begin{tabular}{rrrrr} 
& Unique & Overlap & Duplicates & Total \\
\cline { 2 - 5 } Johnson (2018) & 422 & 266 & 9 & 697 \\
Florentine (2011) & 138 & 266 & 0 & 404
\end{tabular}

Table B-2: Reinterpretation Florentine (2011) and Johnson (2018) inventories of southwest Montana and northeast Wyoming. The Rock Glaciers columns show my subcategorization and Removed are features that do not fit my criteria and are not Features of Interest. Numbers within the parenthesis in the Johnson row are the number of overlapping features between Johnson and Florentine's inventories. The Trcka row indicates rock glaciers not identified by the other two inventories. Total is the total for the region (summing the numbers of Johnson, Florentine, and Trcka minus the overlapping features).

\begin{tabular}{|c|c|c|c|c|c|c|}
\hline \multirow[b]{3}{*}{ Johnson } & \multicolumn{3}{|c|}{ Rock Glaciers } & \multirow{2}{*}{$\begin{array}{l}\text { Features } \\
\text { of Interest }\end{array}$} & \multirow{2}{*}{ Removed } & \multirow{2}{*}{ Total } \\
\hline & Active & Inactive & Total & & & \\
\hline & 124 (93) & $80 \quad(65)$ & $204 \quad(158)$ & (107) & $65 \quad(1)$ & 697 \\
\hline Florentine & 104 & 70 & 174 & 205 & 25 & 404 \\
\hline Trcka & 9 & 6 & 15 & 7 & 0 & 22 \\
\hline Total & 144 & 91 & 235 & 533 & 89 & \\
\hline
\end{tabular}

My inventory generally agrees with both Florentine's (2011) and Johnson's (2018) that the features are either rock glacier or FOI. I removed only $6 \%$ (25) and 9\% (65) of the features, respectively (Table B-2). Most features in both inventories, 51\% (205) and $61 \%$ (428), respectively, were reclassified as FOI. Although some features are 
have over-steepened lower margins, they do not extend into the valley (Figure B-2a, b).

Features that were excluded from my inventory do not show an over-steepened lower margins, indicative possible internal ice, and others do not exhibit positive relief (Figure B-2c, d).
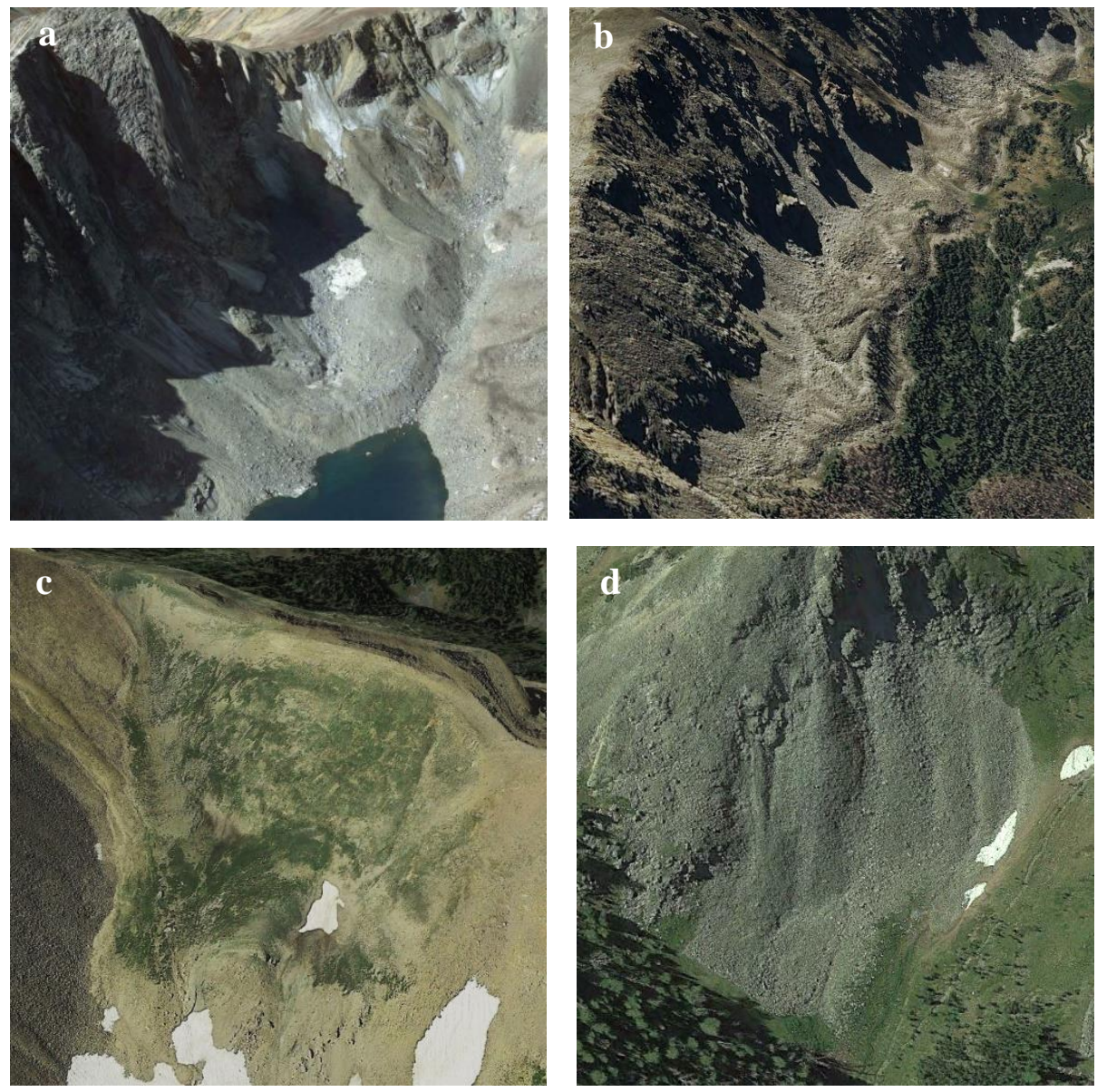

Figure B-2: Examples of reclassified features, (a) a feature of interest identified by Florentine (2011) as a rock glacier (Beartooth-Absaroka Range, Montana, $45.17072^{\circ},-109.8935^{\circ}$ ); (b) a feature of interest identified by both Florentine (2011) and Johnson (2018) as a rock glacier (Beartooth- Absaroka Range, Montana, 45.13638 ${ }^{\circ}$ $\left.109.4715^{\circ}\right)$. Features that were excluded from my inventory, (c) bedrock identified by Florentine (2011) as a rock glacier (BeartoothAbsaroka Range, Montana, 45.014991º, -111.418689 ${ }^{\circ}$ ); (d) a talus slope identified by Johnson (2018) as a rock glacier (BeartoothAbsaroka Range, Montana, $\left.45.10566^{\circ},-110.5531^{\circ}\right)$. Image source: Google Earth Pro. 
Florentine's rock glacier criteria are more specific than my criteria (pg. 16). The major difference between inventories that accounts for most of the reclassification to FOI, is that I specify that rock glaciers extend into the valley. This indicates significant movement and is different from a talus accumulation or a protalus rampart, both of which may contain ice but are not moving. Another difference is elevation, Florentine argues that rock glaciers originate above the tree-line $(\sim 2000 \mathrm{~m})$. While this is true for her region of study, it is not true in other parts of the western US, and I do not include this criterion in my classification.

\section{Comparison with Millar and Westfall's (2019) rock glacier inventory in the Great Basin}

Millar, C.I., and Westfall, R.D., 2019, Geographic, hydrological, and climatic significance of rock glaciers in the Great Basin, USA: Arctic, Antarctic, and Alpine Research, doi: 101080/15230430.2019.1618666

Millar and Westfall (2019) inventoried rock glaciers within the boundary of the Great Basin using Google Earth Pro (GEP; versions 7.3.1 and 7.3.2) and they checked some features in the field ( Figure B-3). The characteristics they used to identify rock glaciers were based on Wahrhaftig and Cox (1959) and Barsch's (1996) 'classic rock glacier' characteristics which include; "a tongue-shaped or lobate form, over-steepened sides and/or fronts, and often having furrowed surfaces ... Other landforms included as 'rock glaciers' were referred to as sidewall rock glaciers or protalus ramparts with characteristics of being wider than long, have over-steepened fronts, and are located in cirques, valley heads, or under crests and valley walls". These additional landforms were included because they may contain perennial ice. The features were categorized into five 
morphological types " $R G C$-classic rock glacier in a cirque setting, $T A L V$-rampart below talus and along a valley or ridge wall, TALC-rampart or nascent lobate/tongue-shaped feature below talus located in a cirque or along the main crest, or in a headwall setting, BSR - boulder stream rampart, with subdued features relative to a rock glacier or protalus rampart, and SLUMP- a feature with over-steepened fronts with an unknown origin". The only distinction between the RGC, TALV, and TALC categories are the locations in which the features form, whether in a cirque (RGC), below talus along a valley or ridge wall (TALV) or below talus in a cirque or along the main crest/ headwall setting (TALC).

Millar and Westfall assigned activity levels based on the morphological characteristics of identified by Liu et al. (2013). They found a number of characteristics, not all of which are necessarily present, that characterize features that are actively moving within the RGC, TALC, and TALV categories. These characteristics include: "steep front and sides, steep-crested furrows, little to no vegetation, has some sort of water below the front, has a persistent ice field above the feature, and large and unweathered boulders at the front and sides. Features that had most or all of the characteristics of an active rock glacier were labeled active. Features that had little or none of those characteristics were labeled relict. Lastly, features that have an intermediate number of characteristics but are more similar to active were labeled inactive". They assume that rock glaciers in the Great Basin are unlikely to be debriscovered glaciers because of the "ice in the headwall being separated from rock glaciers, the lack of active Little Ice Age glaciation outside of the Sierra Nevada Range, and the 
lack of moraine evidence for extensive glaciers in the Sierra Nevada Range during the Little Ice Age."

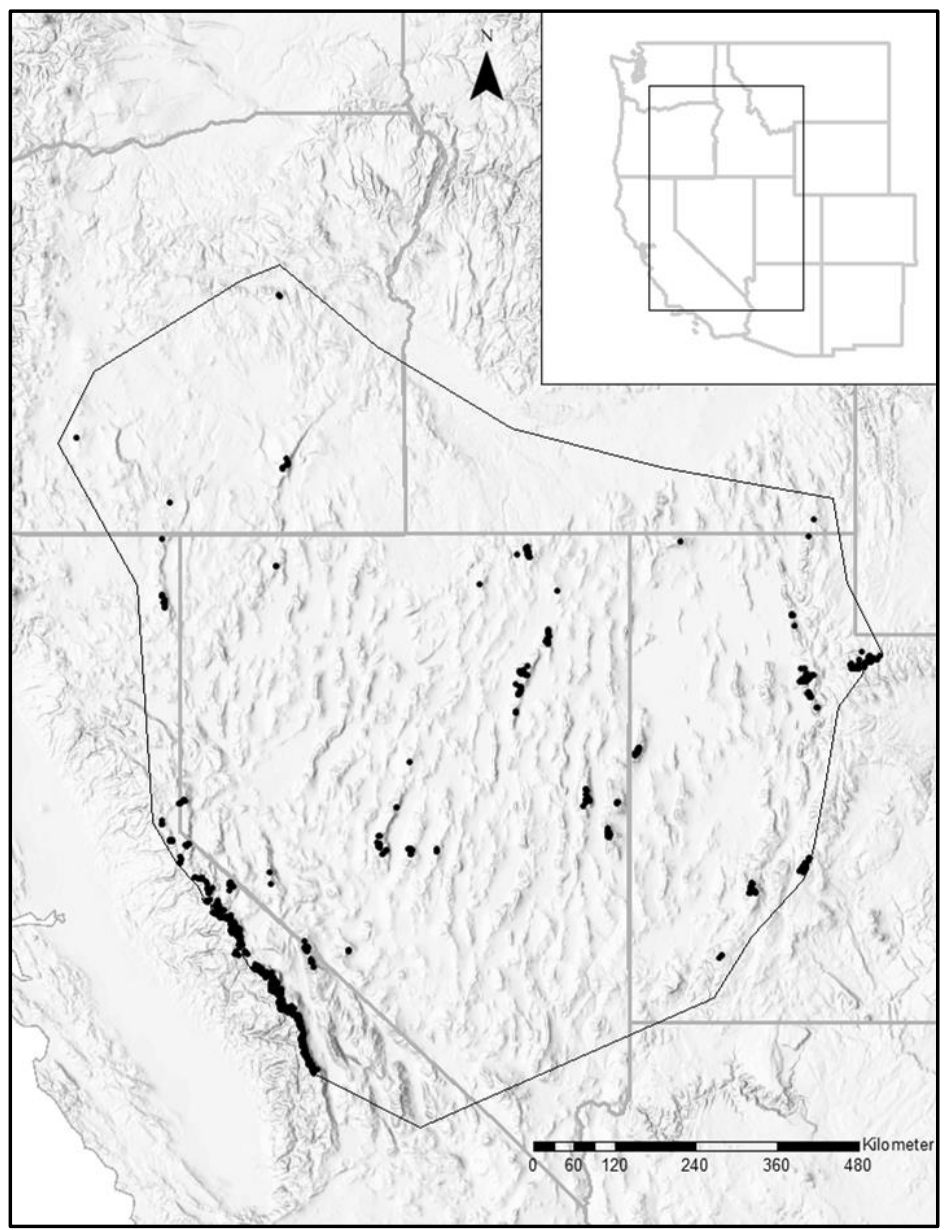

Figure B-3: The Millar and Westfall (2019) rock glacier inventory (filled circles) within the Great Basin (solid line) on a shaded relief map.

They identified 842 features as rock glaciers compared to Johnson's (2018) 706; 363 features common to both (Table B-3). My re-examination of all 1,185 features identifies 178 rock glaciers, 926 features of interest (FOI), and 81 features eliminated (Table B-4). I found 5 rock glaciers not included in either inventory and added 2 FOI. 
Table B-3: The number of features identified as rock glaciers in Millar and Westfall (2019) and Johnson (2018) inventories. Features that are included in only one inventory are Unique, those that are common to both inventories are Overlap, and Duplicates are those features that have two location points, suggesting double counting.

\begin{tabular}{rrrrr} 
& Unique & Overlap & Duplicates & Total \\
\cline { 2 - 5 } Johnson (2018) & 336 & 363 & 7 & 706 \\
Millar and Westfall (2019) & 468 & 363 & 11 & 842
\end{tabular}

Table B-4: Reinterpretation of Millar and Westfall (2019) and Johnson (2018) inventories if the Great Basin. The Rock Glaciers columns show my subcategorization and Removed are features that do not fit my criteria and are not Features of Interest. Numbers within the parenthesis in the Johnson row are the number of overlapping features between Johnson and Millar and Westfall's inventories. The Trcka row indicates rock glaciers not identified by the other two inventories. Revised Total is the total for the region (summing the numbers of Millar and Westfall, Johnson, and Trcka minus the overlapping features).

\begin{tabular}{|c|c|c|c|c|c|c|}
\hline \multirow[b]{3}{*}{ Johnson } & \multicolumn{3}{|c|}{ Rock Glaciers } & \multirow{2}{*}{$\begin{array}{c}\text { Feature of } \\
\text { Interest }\end{array}$} & \multirow{2}{*}{ Removed } & \multirow{2}{*}{ Total } \\
\hline & Active & Inactive & Total & & & \\
\hline & $114 \quad(97)$ & $38 \quad(33)$ & 152 (130) & 492 (226) & $62 \quad(7)$ & 706 \\
\hline $\mathrm{M} \& \mathrm{~W}$ & 114 & 42 & 156 & 660 & 26 & 842 \\
\hline Trcka & 4 & 1 & 5 & 2 & 0 & 7 \\
\hline Total & 135 & 48 & 183 & 928 & 81 & \\
\hline
\end{tabular}

My inventory generally agrees with Millar and Westfall's (2019) and Johnson's (2018) that features were either rock glaciers or FOI. I removed only 3\% (26) and 9\% (62) of the features, respectively (Table B-4). Most features in both inventories, $78 \%$ (660) and 70\% (492), respectively, were reclassified as FOI. Although some features are have over-steepened lower margins, they do not extend into the valley (Figure B-4a, b). Features that were excluded from my inventory do not show an over-steepened lower margins, indicative possible internal ice, and others do not exhibit positive relief (Figure B-4c, d). 

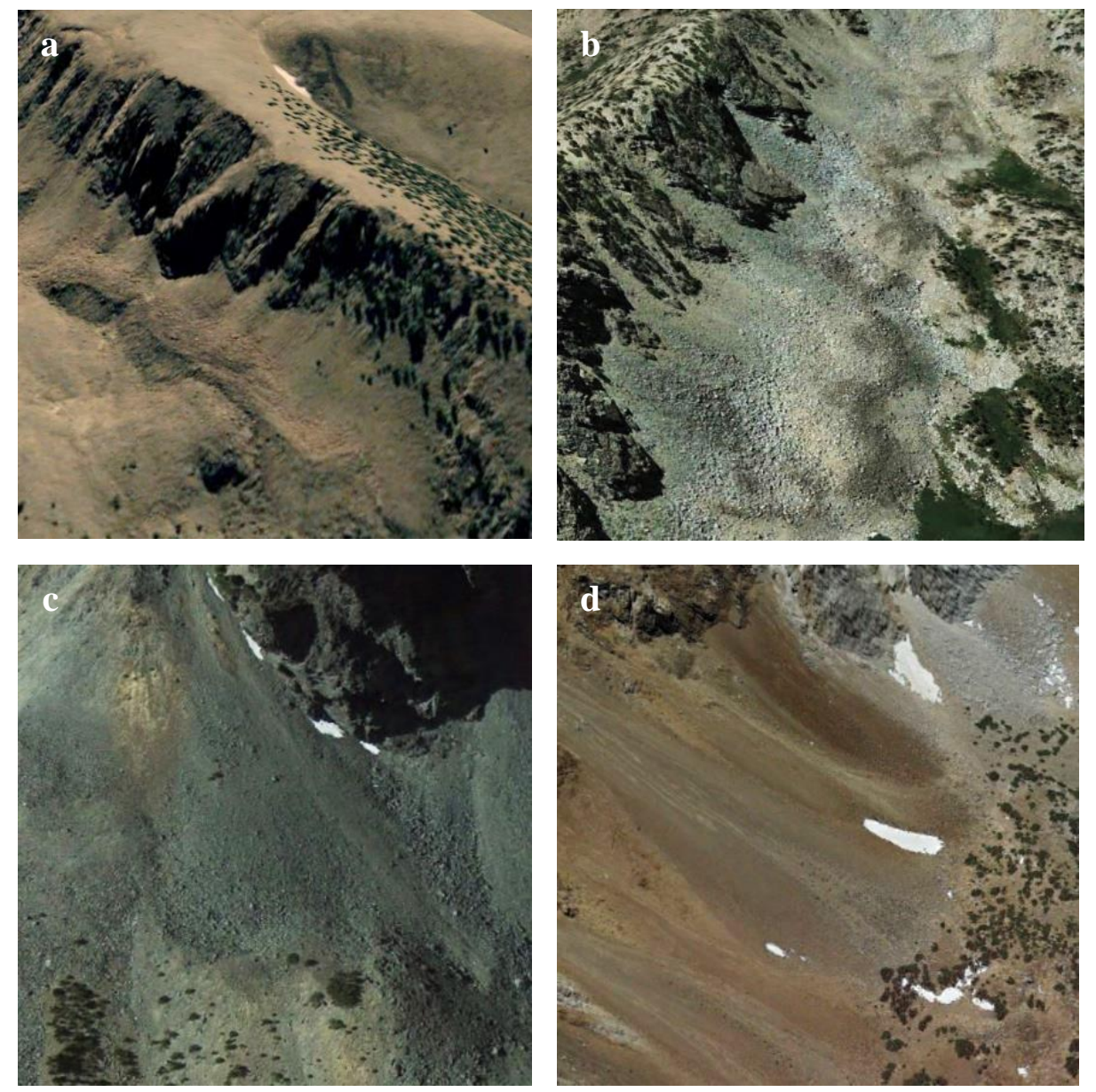

Figure B-4: Examples of reclassified features, (a) a feature of interest identified by Millar and Westfall (2019) as a rock glacier (Toiyabe Range, Nevada, $38.879678^{\circ},-117.363624^{\circ}$ ); (b) a feature of interest identified by both Millar and Westfall (2019) and Johnson (2018) as a rock glacier (Sierra Nevada Range, California, $38.37189^{\circ}$, $\left.119.5974^{\circ}\right)$. Features that were excluded from my inventory, (c) a glacial moraine identified by Millar and Westfall (2019) as a rock glacier (Sierra Nevada Range, California, $38.062962^{\circ},-119.301573^{\circ}$ ); (d) a talus slope identified by Johnson (2018) as a rock glacier (Sierra Nevada Range, California, $\left.37.42899^{\circ},-118.7182^{\circ}\right)$. Image source: Google Earth Pro.

Millar and Westfall classified their features into five categories, RGC, TALC,

TALV, SLUMP, and BSR and which span my re-interpretation (Table B-5). About half of the RGC features, 44\% (117), are classified as rock glaciers according to my criteria. The majority, 90\% (523), of features in the TALV, TALC, SLUMP, and BSR categories, 
I classify as features of interest. Our two classifications agree that these features probably

have ice, but we disagree on whether they are rock glaciers (Figure B-5).

Table B-5: A comparison between Millar and Westfall's morphological classification (rows) and my re-interpretation (columns). RGC is a classic rock glacier in a cirque setting, TALV is a rampart below talus, and along the valley or ridge wall, TALC is a rampart or nascent lobate/tongue-shaped feature below talus located in a cirque or along the main crest, or in a headwall setting. SLUMP is a feature with over-steepened fronts with an unknown origin. BSR is a boulder stream rampart, with subdued features relative to a rock glacier or protalus rampart.

\begin{tabular}{lrrrrrr} 
& \multicolumn{3}{c}{ Rock Glaciers } & Feature of & Removed & Total \\
\cline { 2 - 5 } & Active & Inactive & Total & Interest & 10 & 264 \\
RGC & 89 & 28 & 117 & 137 & 6 & 210 \\
TALC & 18 & 8 & 26 & 178 & 7 & 343 \\
TALV & 7 & 6 & 13 & 323 & 2 & 13 \\
SLUMP & 0 & 0 & 0 & 11 & 1 & 12 \\
BSR & 0 & 0 & 0 & 11 &
\end{tabular}
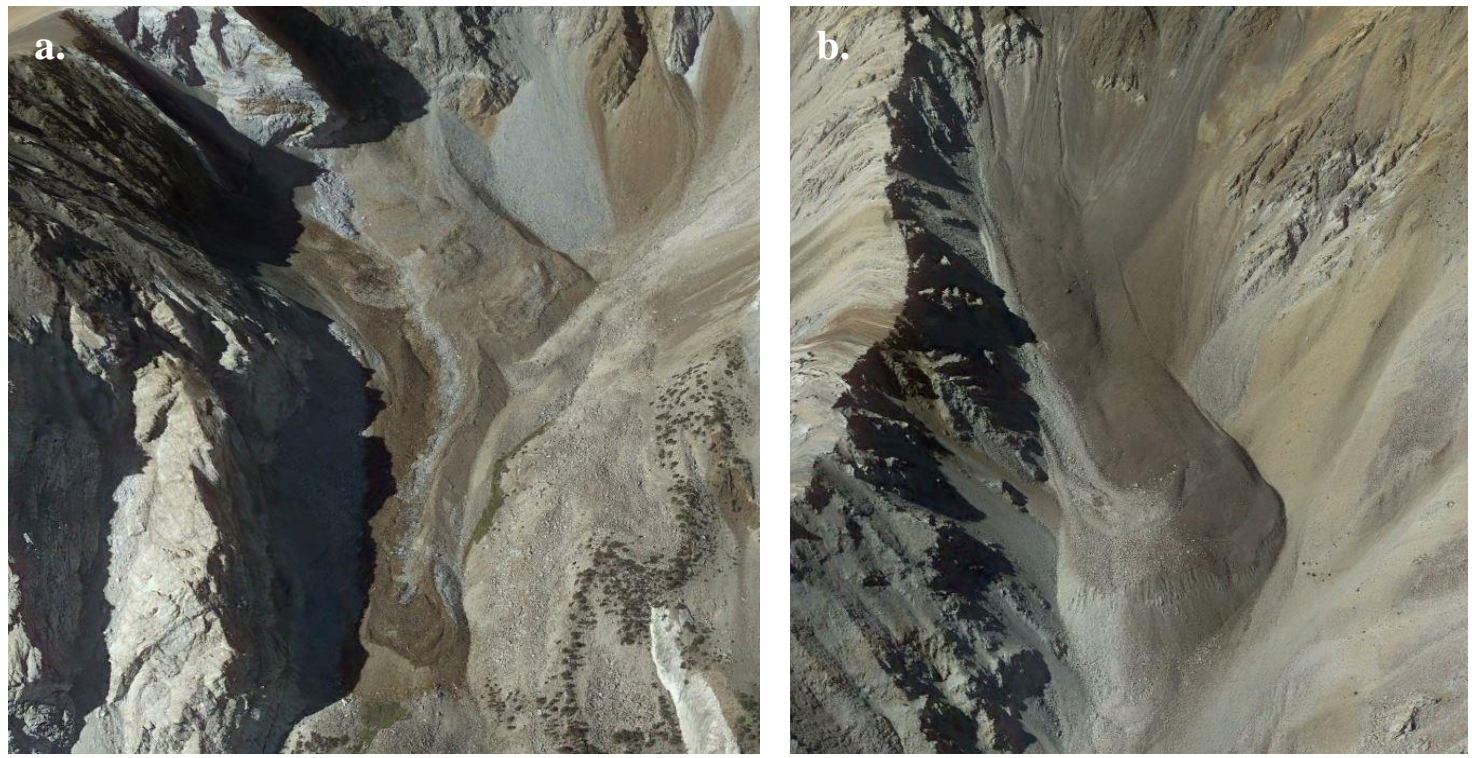

Figure B-5: Examples of reclassified as rock glaciers but Millar and Westfall classified as, a) a rampart below talus, and along the valley or ridge wall (TALV) (Sierra Nevada Range, California, 37.26418, -118.6556); b) a rampart or nascent lobate/tongue-shaped feature below talus located in a cirque or along the main crest, or in a headwall setting (TALC). (Sierra Nevada Range, California, 37.35454, 118.6507). Image source: Google Earth Pro. 
Of the Millar and Westfall (2019) categories most similar to my rock glacier criteria is RGC. The majority of their active features, 59\% (83), match my classification of active rock glaciers, the remaining 58 I classify as FOI or were removed (Table B-6). The majority of their inactive, 63\% (31), and relict, 70\% (52), RGC features, I classify as FOI.

Table B-6: A comparison of the activity level between my inventory and that of Millar and Westfall's (2019) classic rock glacier in a cirque category (RGC). Columns indicate my classification and rows indicate Millar and Westfall's.

\begin{tabular}{rrrrrrrr} 
& \multicolumn{3}{c}{ Rock Glaciers } & Feature of & Removed & Total \\
\cline { 2 - 6 } & Active & Inactive & Total & Interest & & \\
\cline { 2 - 7 } M\&W- Active & 76 & 7 & 83 & 54 & 4 & 141 \\
M\&W- Inactive & 10 & 7 & 17 & 31 & 1 & 49 \\
M\&W - Relict & 3 & 14 & 17 & 52 & 5 & 74 \\
\cline { 2 - 6 } Total & 89 & 28 & 117 & 137 & 10 &
\end{tabular}

Millar and Westfall's rock glacier criteria are similar my criteria (pg. 16). The cause of the major difference in the inventories is my specification that rock glaciers have to extend into the valley This indicates significant movement and is different from a talus accumulation or a protalus rampart, both of which may contain ice but are not moving.

\section{Comparison with Riffle's (2018) rock glacier inventory in the eastern Cascades, Washington}

Riffle, A., 2018, Internal composition, structure, and hydrological significance of rock glaciers in the Eastern Cascades, Washington [M.S. Thesis]: Central Washington University, $156 \mathrm{p}$.

Riffle's (2018) inventory is based on Weidanaar's (2013), who used Google Earth and field observations to identify rock glaciers on the east side of the Cascade Range, Washington (Figure B-6). His criteria included, a lobate or tongue-shaped mass of rock, 
steep side and front slopes, "movement away from its source area, a visible source of past or present rockfall from a cirque cliff or headwall, transverse or longitudinal ridges and furrows, surface pits in the rock mass". Weidanaar further classified his rock glaciers based on its genesis. "Glaciogenic rock glaciers were identified by its proximity to current glacial ice, location near cirques and the existence of fine morainal debris. Debris-type were identified by their location next to avalanche chutes and couloirs. Gelifluction-type were identified by their lack of avalanche chutes and couloirs and their association with boulder and talus fields". Activity was also classified into three categories: active, inactive, and relict. Active rock glaciers have little to no vegetation cover and front slopes $>35^{\circ}$. Inactive rock glaciers have less than $50 \%$ vegetation cover and front slopes between $20-35^{\circ}$. Relict rock glaciers have more than $50 \%$ vegetation cover and front slopes of less than $20^{\circ}$. Riffle (2018) updated Weidannar's (2013) classifications based on field observations. The rock glaciers Riffle assessed in the field were different than the ones Weidannar's assessed. Overall, three rock glacier activity categories were changed from field observations, and two rock glacier genesis categories were changed with the use of ground penetrating radar. 


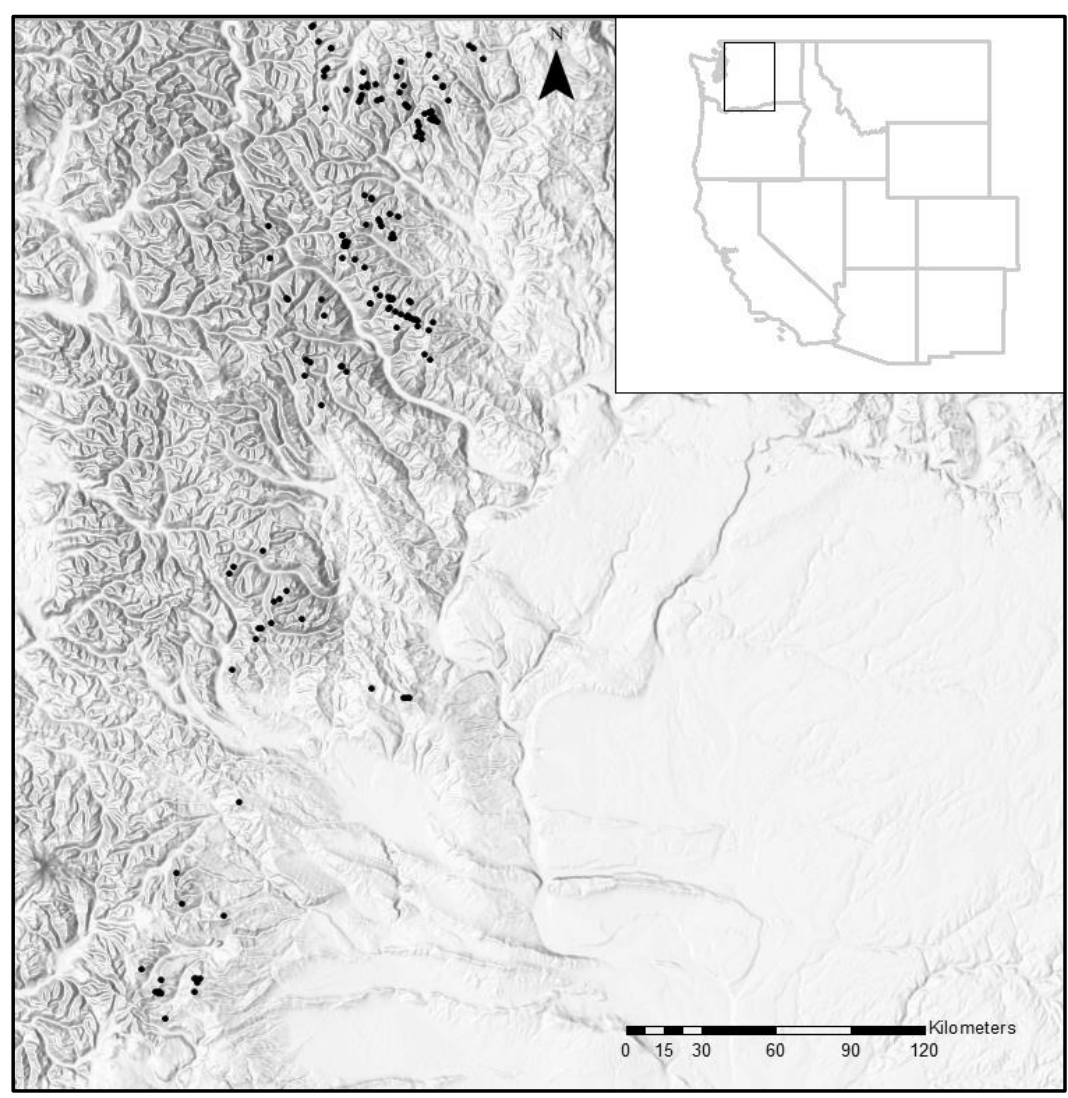

Figure B-6: The Riffle (2018) rock glacier inventory (filled circles) on a shaded relief map.

He identified 140 features as rock glaciers compared to Johnson's (2018) 287; 77 features were common to both (Table B-7). My re-examination of all 350 features identifies 35 rock glaciers, 236 features of interest, and 79 features eliminated (Table B8). I added one feature of interest.

Table B-7: The number of features identified as rock glaciers within Riffle (2018) and Johnson (2018) inventories. Features that are included in only one inventory are Unique, and those that are common to both inventories are Overlap.

\begin{tabular}{rrrr} 
& Unique & Overlap & Total \\
\cline { 2 - 4 } Johnson (2018) & 210 & 77 & 287 \\
Riffle (2018) & 63 & 77 & 140
\end{tabular}


Table B-8: Reinterpretation of Riffle (2018) and Johnson (2018) inventories of the east side of the Cascades, Washington. The Rock Glaciers columns show my subcategorization, and Removed are features that do not fit my criteria and are not Features of Interest. Numbers within the parenthesis in the Johnson row are the number of overlapping features between Johnson and Riffle's inventories. The Trcka row indicates rock glaciers not identified by the other two inventories. Total is the total for the region (summing the numbers of Johnson, Riffle, and Trcka minus the overlapping features).

\begin{tabular}{|c|c|c|c|c|c|c|}
\hline \multirow[b]{3}{*}{ Johnson } & \multicolumn{3}{|c|}{ Rock Glaciers } & \multirow{2}{*}{$\begin{array}{c}\text { Feature } \\
\text { of } \\
\text { Interest }\end{array}$} & \multirow{2}{*}{ Removed } & \multirow{2}{*}{ Total } \\
\hline & Active & Inactive & Total & & & \\
\hline & $12 \quad(8)$ & 18 (14) & $30 \quad(22)$ & $194 \quad(50)$ & $63 \quad(5)$ & 287 \\
\hline Riffle & 10 & 17 & 27 & 92 & 21 & 140 \\
\hline Trcka & 0 & 0 & 0 & 1 & 0 & 1 \\
\hline Total & 14 & 21 & 35 & 237 & 79 & \\
\hline
\end{tabular}

My inventory generally agrees with Riffle's (2018) and Johnson's (2018) that the features were either rock glaciers or FOI. I only removed $15 \%$ (21) and 22\% (63) respectively (Table B-8). Most features in both inventories, 66\% (92) and 68\% (194), respectively, were reclassified from rock glaciers to features of interest. Although some features are have over-steepened lower margins, they do not extend into the valley (Figure B-7a, b). Features that were excluded from my inventory do not show oversteepened lower margins, indicative of possible internal ice, and others do not exhibit positive relief (Figure B-7c, d). 

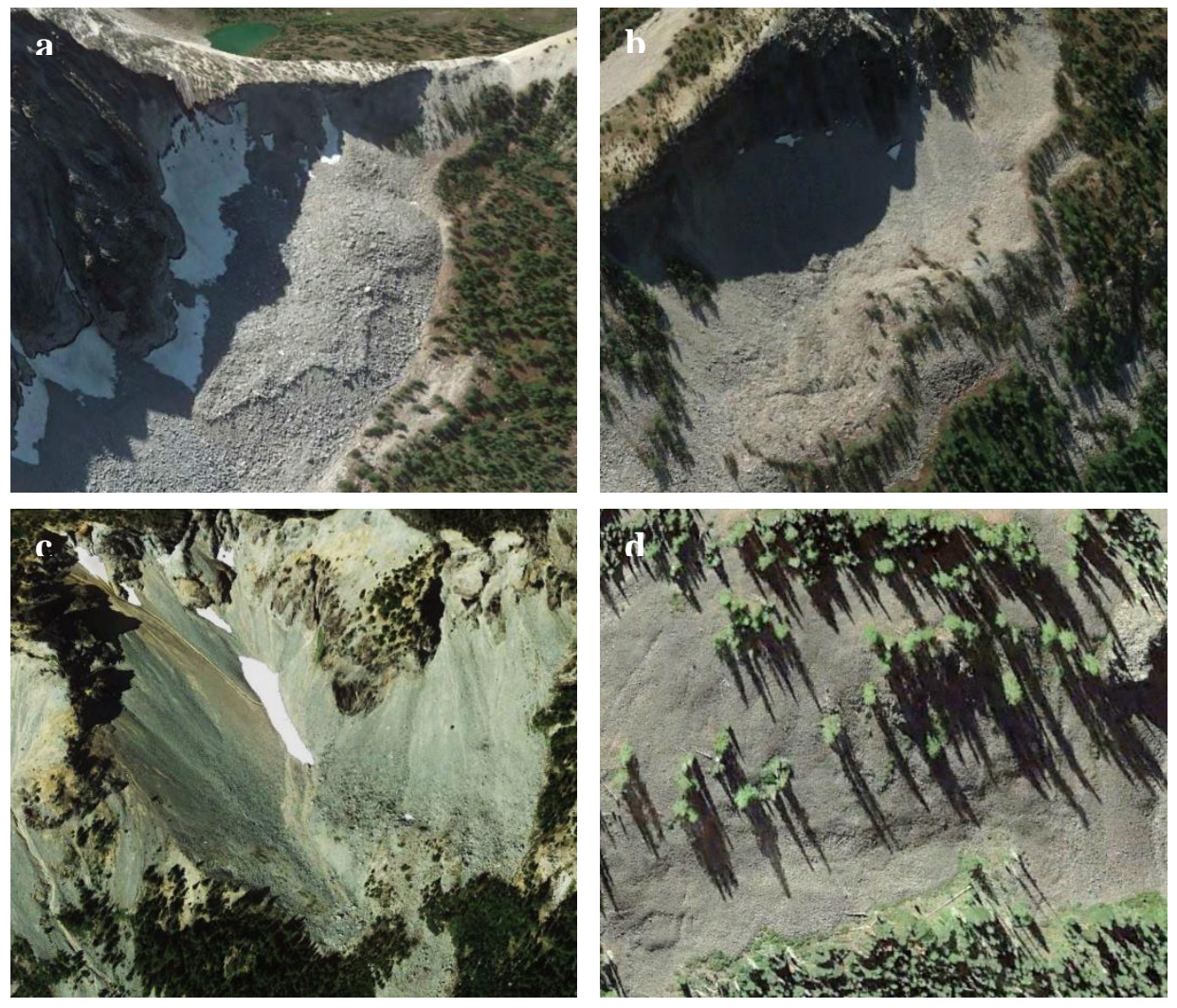

Figure B-7: Examples of reclassified features, (a) a feature of interest identified by both Riffle (2018) and Johnson (2018) as a rock glacier (Cascade Range, Washington, $48.25563^{\circ},-120.4335^{\circ}$ ); (b) a feature of interest identified by (2018) as a rock glacier (Cascade Range, Washington, $48.31802^{\circ},-120.559^{\circ}$ ). Features that were excluded from my inventory, (c) a talus slope identified by Johnson (2018) as a rock glacier (Cascade Range, Washington, $46.840079^{\circ},-121.254562^{\circ}$ ); (d) bedrock identified by Riffle (2016) as a rock glacier (Cascade Range, Washington, $\left.46.727339^{\circ},-121.090315^{\circ}\right)$. Image source: Google Earth Pro.

Riffle classified 33 features as active rock glaciers, of which $48 \%$ (16) match my criteria, the remaining 17 I classify as FOI (Table B-9). The majority of his inactive, 70\% (68), and relict, 38\% (7) rock glaciers, I classify as FOI. We agree that the features are no longer moving but disagree on whether or not they are rock glaciers. 
Table B-9: A comparison of the activity level between mine and Riffle's (2018) inventories. Columns indicate my classification and rows indicate Riffle's.

\begin{tabular}{rrrrrrr} 
& \multicolumn{2}{c}{ Rock Glaciers } & \multicolumn{2}{c}{$\begin{array}{c}\text { Features } \\
\text { of }\end{array}$} & Removed & Total \\
\cline { 2 - 7 } Active & Inactive & Total & Interest & & \\
Riffle- Active & 10 & 6 & 16 & 17 & 0 & 33 \\
Riffle- Inactive & 0 & 9 & 9 & 68 & 15 & 97 \\
Riffle- Relict & 0 & 2 & 2 & 7 & 6 & 18 \\
\cline { 2 - 7 } Total & 10 & 17 & 27 & 92 & 21 &
\end{tabular}

Riffle's rock glacier criteria are more specific than my criteria (pg. 16). The major difference is that I specify that rock glaciers extend into the valley. This indicates significant movement and is different from a talus accumulation or a protalus rampart, both of which may contain ice but are not moving. Another difference, although this does not affect differences our in our inventories is the presence of surface pits. Riffle argues that surface pits are necessary to rock glaciers whereas I ignore them. Several studies show that surface pits are only seen on inactive and relict rock glaciers (Johnson et al., 2007; Kristensen et al., 2007; Kellerer-Pirklbauer et al., 2012; Seligman, 2009). Another criteria of disagreement is vegetation, which also does not affect differences in our inventories, Riffle (2018) argues that active rock glaciers lack vegetation, but several studies show that sparse vegetation can be present (Liu et al., 2013; Rangecroft et al., 2014; Uxa and Mida, 2017; Colucci et al., 2019; Millar and Westfall, 2019). 


\section{Comparison with Johnson's (2006) inventory in the Lemhi Range, Idaho}

Johnson, B.G., 2006, The effect of topography, latitude, and lithology on rock glacier distribution in the Lemhi Range, central Idaho, USA [MS thesis]: Idaho State University, 135p. doi: 10.1016/j.geomorph.2007.01.023.

Johnson (2006) inventoried rock glaciers in the Lemhi Range, Idaho (Figure B-8). He defined rock glacier environments as landscapes above of $9000 \mathrm{ft}(2743 \mathrm{~m})$, slopes less than $21^{\circ}$, and aspects between $300^{\circ}-60^{\circ}$. He then searched for rock glaciers, within these topographic limits, using black and white aerial stereo-photos flown in 1970. The aerial photos were digitally scanned and, using ArcMap, were georeferenced. Five rock glaciers were visited in the field to identify signs of stability, evidence of movement, and observe general morphology. A classification scheme, based on both field and remotely observed morphology, grouped the rock glaciers into three categories, "active rock glaciers, indicated by a dominantly smooth upper surface that can contain small ripples, has little or no lichen cover, the toe is over-steepened and it is free of vegetation; inactive rock glaciers, indicated by ridges and furrows on the surface in a parabolic pattern, lichen appears on the crests of the ridges, the surface has isolated circular or elongated pits, and the toe is unstable occasionally containing small patches of vegetation; and relict rock glaciers which exhibit a heavily pitted surface, are usually covered with lichen, and which toes are covered with mature vegetation". I did not have access to his sub-categorization and viewed all as simply rock glaciers. 


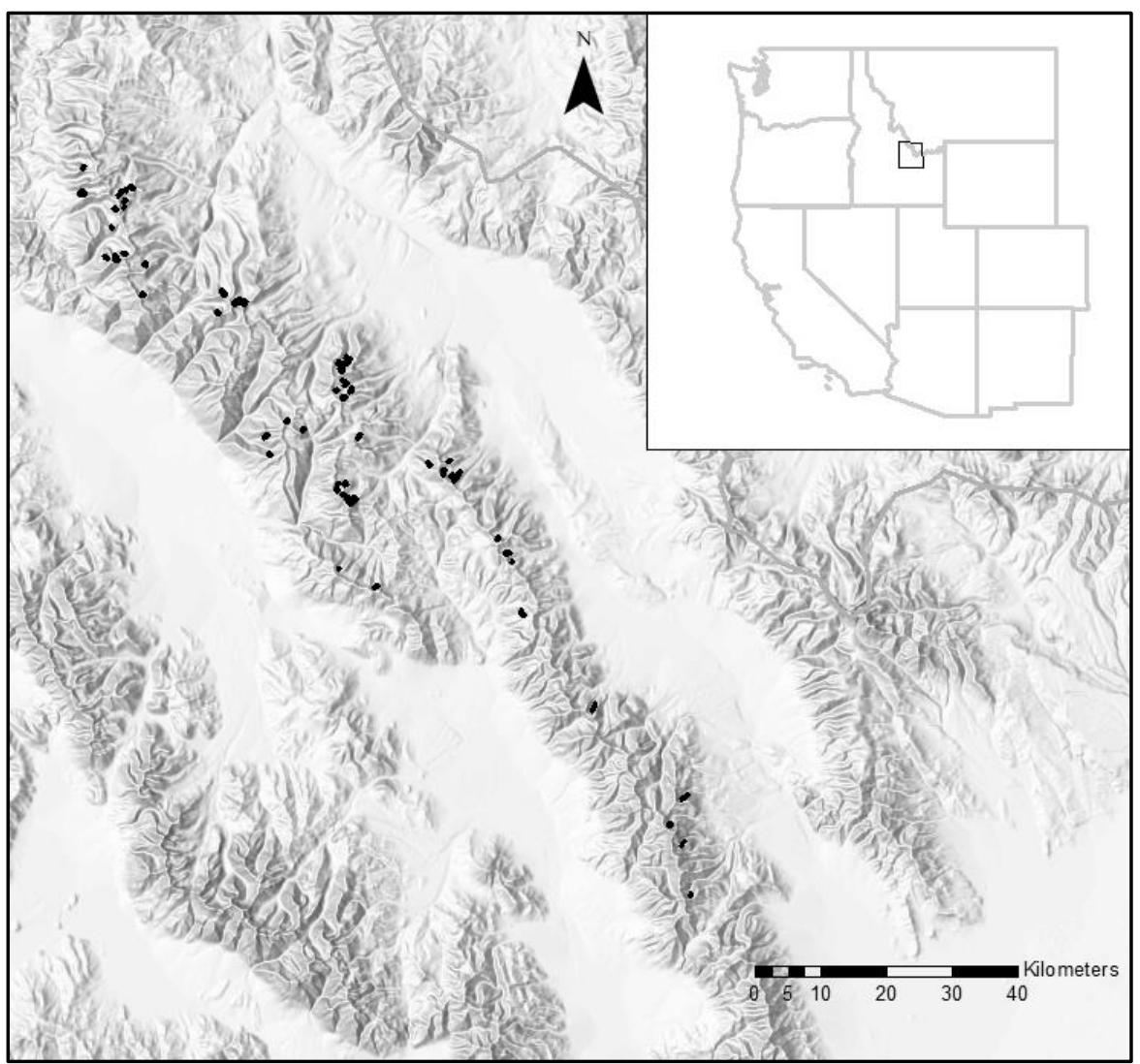

Figure B-8: The Johnson (2006) rock glacier inventory (filled circles) on a shaded relief map.

He identified 53 features as rock glaciers compared to Johnson's (2018) 405; 52

features common to both (Table B-10). I re-interpreted nine of Johnson's (2006) outlines as multiple features (15) because the outlines included other rock glaciers and/or nonrock glacier features (Figure B-9). My re-examination of all 406 features identifies 82 rock glaciers, 296 features of interest, and 28 features eliminated (Table B-11).

Table B-10: The number of features identified as rock glaciers within Johnson's (2006) and Johnson's (2018) inventories. Features that are included in only one inventory are Unique, those that are common to both inventories are Overlap, Similar are the number of features I re-interpreted as other features within nine of Johnson's (2006) outlines, and Duplicates are those features that have two location points, suggesting double counting.

Johnson (2018)

Johnson (2006)

\section{Unique Overlap Similar Duplicates Total}

$\begin{array}{lllll}335 & 52 & 15 & 3 & 405\end{array}$

$\begin{array}{llll}52 & 0 & 0 & 53\end{array}$




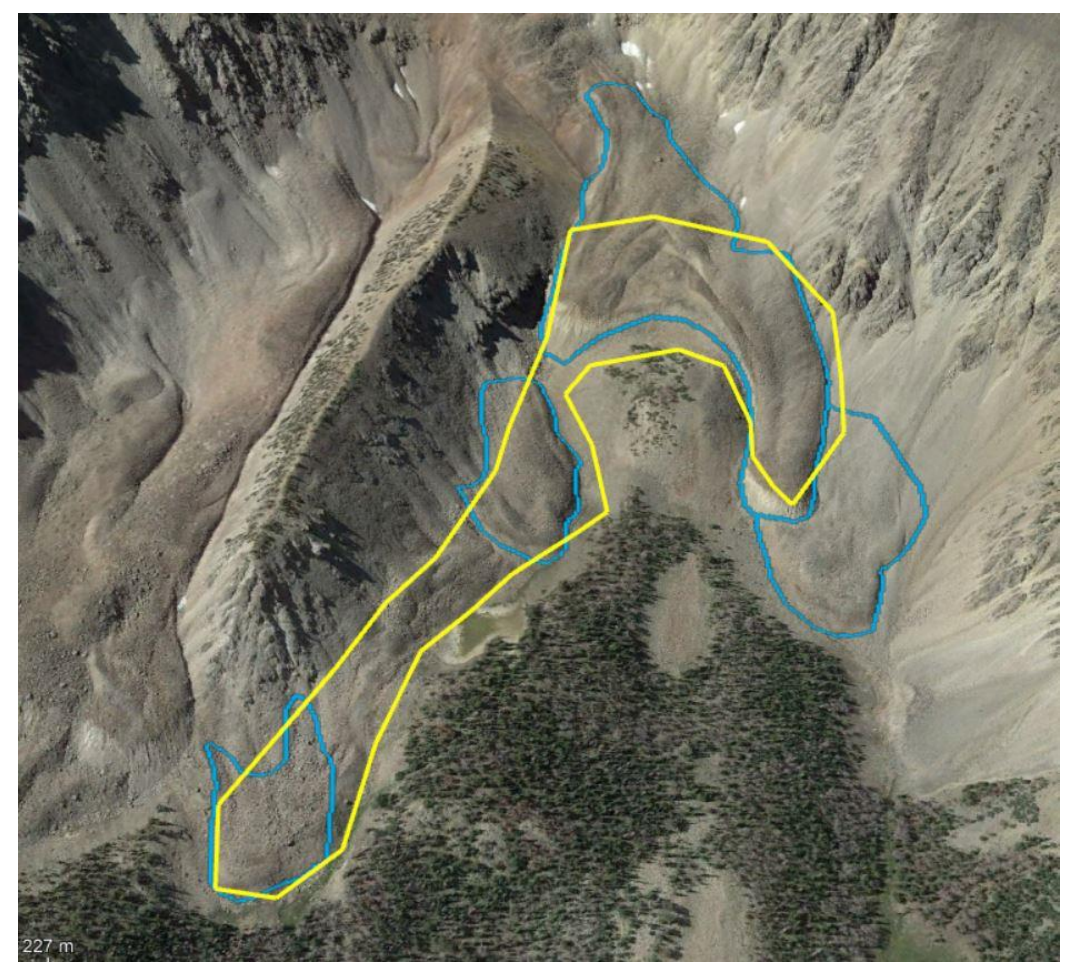

Figure B-9: An example of one of Johnson's rock glaciers (yellow) and my re-interpretation which includes multiple active rock glaciers (blue).

Table B-11: Reinterpretation of Johnson (2006) and Johnson (2018) inventories of the Lemhi Range, Idaho. The Rock Glaciers columns show my subcategorization, and Removed are features that do not fit my criteria and are not Features of Interest. Numbers within the parenthesis in the Johnson (2018) row are the number of overlapping features between Johnson (2018) and Johnson's (2006) inventories. The Trcka row indicates rock glaciers not identified by the other two inventories. Total is the total for the region (summing the numbers of Johnson (2006), Johnson (2018), and Trcka minus the overlapping features).

\begin{tabular}{|c|c|c|c|c|c|c|}
\hline \multirow[b]{3}{*}{ Johnson (2018) } & \multicolumn{3}{|c|}{ Rock Glaciers } & \multirow{2}{*}{$\begin{array}{c}\text { Feature of } \\
\text { Interest }\end{array}$} & \multirow{2}{*}{ Removed } & \multirow{2}{*}{ Total } \\
\hline & Active & Inactive & Total & & & \\
\hline & $37 \quad(20)$ & $45 \quad(14)$ & $82 \quad(34)$ & $(30)$ & (1) & 405 \\
\hline Johnson (2006) & 20 & 14 & 34 & 30 & 3 & 67 \\
\hline Trcka & 2 & 0 & 2 & 8 & 0 & 10 \\
\hline Total & 39 & 45 & 84 & 304 & 29 & \\
\hline
\end{tabular}

Overall, my inventory generally agrees with Johnson (2006) and Johnson (2018) in that the features are either rock glaciers or FOI. I removed 4\% (3) and 7\% (27), 
respectively (Table B-11). A fair number of rock glaciers from Johnson's (2006)

inventory, 45\% (30), and most from Johnson's (2018) inventory, 73\% (296) were

reclassified as features of interest. Although some features are have over-steepened lower margins, they do not extend into the valley (Figure B-10a, b). Features that were excluded from my inventory do not show an over-steepened lower margins, indicative of possible internal ice, and others do not exhibit positive relief (Figure B-10c,d).
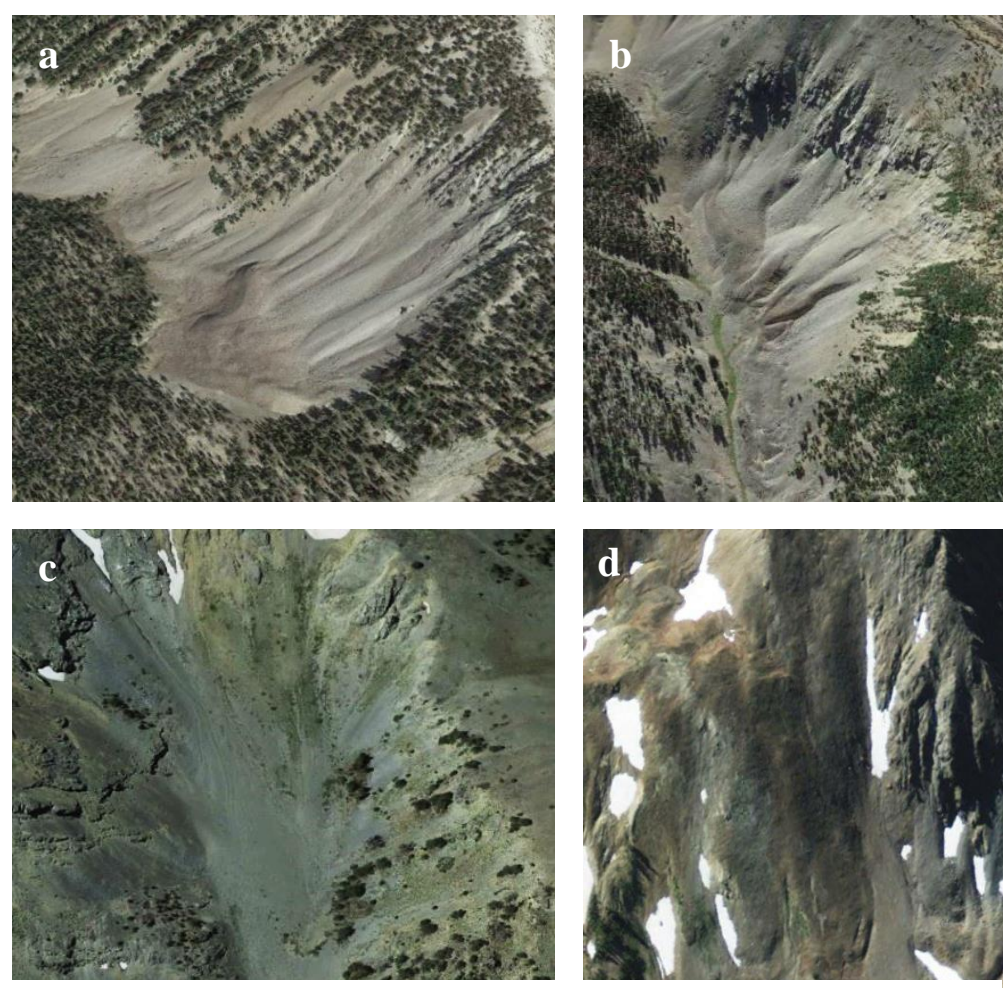

Figure B-10: Examples of reclassified features, (a) a feature of interest identified by Johnson (2018) as a rock glacier (Lemhi Range, Idaho, $44.50237^{\circ},-113.418^{\circ}$ ); (b) a feature of interest identified by both Johnson (2006) and Johnson (2018) as a rock glacier (Lemhi Range, Idaho, $\left.48.81295^{\circ},-114.0493^{\circ}\right)$. Features that were excluded from my inventory, (c) a talus slope identified by Johnson (2018) as a rock glacier (Lemhi Range, Idaho, $44.02173^{\circ}$, $112.9858^{\circ}$ ); (d) a talus slope identified by Johnson (2006) as a rock glacier (Lemhi Range, Idaho, $44.770346^{\circ}$, $\left.113.832983^{\circ}\right)$. Image source: Google Earth Pro. 
Johnson's rock glacier criteria are similar to my criteria (pg. 16). The major difference between inventories that accounts for most of the reclassification to FOI, is that I specify that rock glaciers extend into the valley. This indicates significant movement and is different from a talus accumulation or a protalus rampart, both of which may contain ice but are not moving. Another difference, which did not affect the results, is that Johnson (2006) identifies active rock glaciers as having a dominantly smooth surface and inactive rock glaciers having ridges and furrows in contrast to the findings of other studies (Millar and Westfall, 2019; Liu et al., 2013; Rangecroft et al., 2014). Also, Johnson (2006) argues that active rock glaciers are vegetation-free, but several studies show that sparse vegetation can be present (Liu et al., 2013; Rangecroft et al., 2014; Uxa and Mida, 2017; Colucci et al., 2019; Millar and Westfall, 2019).

Another major difference is Johnson's (2006) topographic specifications, minimum elevations of $9000 \mathrm{ft}(2743 \mathrm{~m})$, and slopes less than $21^{\circ}$. I found rock glaciers with minimum elevations of $2325 \mathrm{~m}$, slopes greater than $21^{\circ}$ and less than $46^{\circ}$, but also with aspects of $300^{\circ}-60^{\circ}$.

\section{Comparison with Kinworthy's (2016) rock glacier inventory in New Mexico}

Kinworthy, B., 2016, New Mexico rock glacier inventory: Analysis of geomorphology and paleogeography [MS thesis]: Missouri State University, 124 p.

Kinworthy (2016) inventoried rock glaciers in New Mexico using Google Earth

(Figure B-11). The characteristics he used to identify rock glaciers include: "lobate structures, steep frontal slope at lowest point of talus accumulation, longitudinal and transverse ridges and furrows, positive relief, vegetation located primarily above the 
frontal lobe, subsidence morphology, no landslide or slump scars, tonal change between frontal and side slopes and the greater body of talus, and proximity to other rock glaciers".

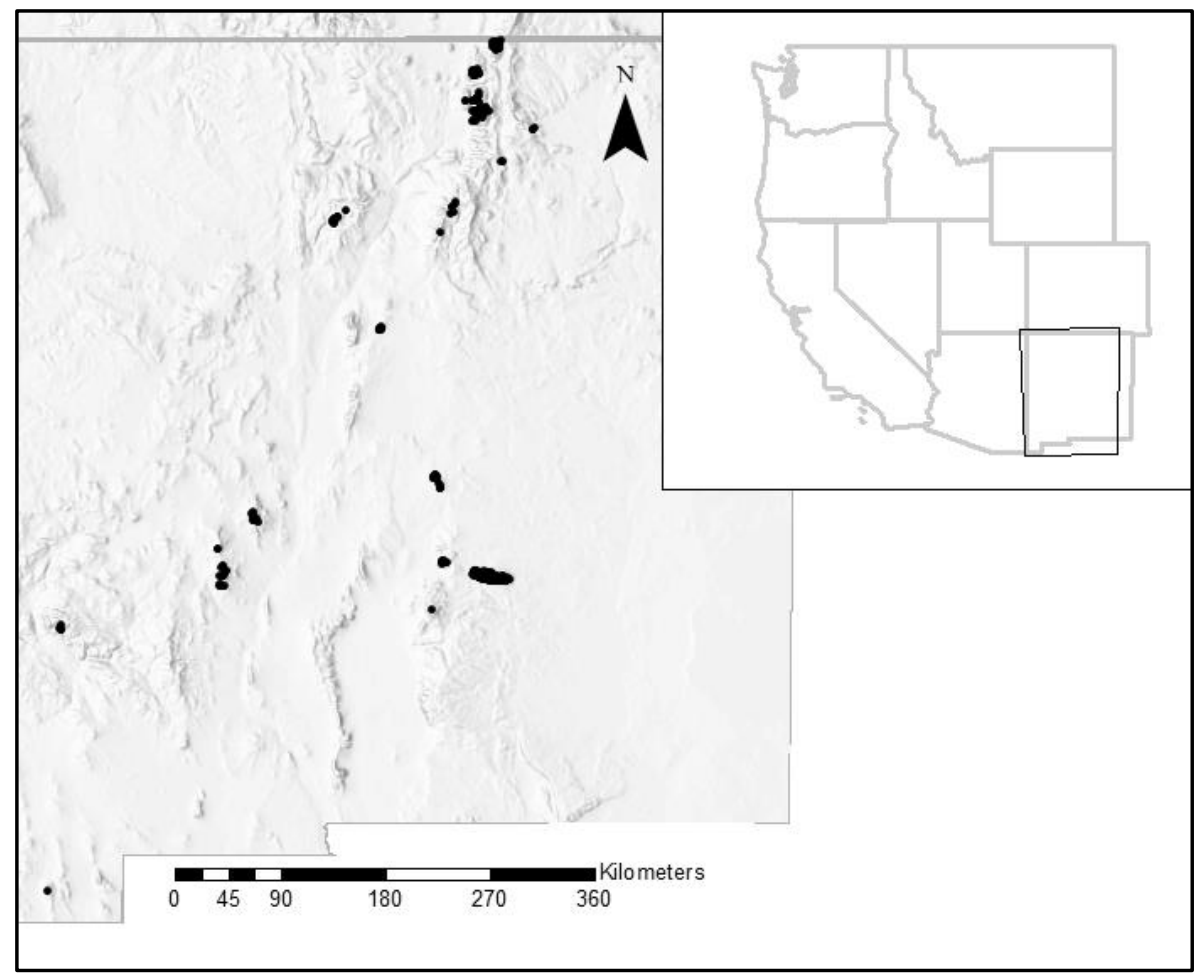

Figure B-11: The Kinworthy (2016) rock glacier inventory (filled circles) on a shaded relief map.

He identified 426 features as rock glaciers compared to Johnson's (2018) 158; 53 features common to both (Table B-12). My re-examination of all 531 features identifies 37 rock glaciers, 171 features of interest, and 323 features eliminated (Table B-13). I found one rock glacier not included in either inventory. 
Table B-12: The number of features identified as rock glaciers in Kinworthy (2016) and Johnson (2018) inventories. Features that are included in only one inventory are Unique, those that are common to both inventories are Overlap.

\begin{tabular}{rrrr} 
& Unique & Overlap & Total \\
\cline { 2 - 4 } Johnson (2018) & 105 & 53 & 158 \\
Kinworthy (2016) & 373 & 53 & 426
\end{tabular}

Table B-13: Reinterpretation of Kinworthy (2016) and Johnson (2018) inventories of New Mexico. The Rock Glaciers columns show my subcategorization and Removed are features that do not fit my criteria and are not Features of Interest. Numbers within the parenthesis in the Johnson row are the number of overlapping features between Johnson and Kinworthy's inventories. The Trcka row indicates rock glaciers not identified by the other two inventories. Revised Total is the total for the region (summing the numbers of Johnson, Kinworthy, and Trcka minus the overlapping features).

\begin{tabular}{|c|c|c|c|c|c|c|}
\hline \multirow[b]{3}{*}{ Johnson } & \multicolumn{3}{|c|}{ Rock Glaciers } & \multirow{2}{*}{$\begin{array}{c}\text { Feature of } \\
\text { Interest }\end{array}$} & \multirow{2}{*}{ Removed } & \multirow{2}{*}{ Total } \\
\hline & Active & Inactive & Total & & & \\
\hline & $15 \quad(7)$ & $9 \quad(4)$ & $24 \quad(11)$ & 121 & 13 (2) & 158 \\
\hline Kinworthy & 7 & 17 & 24 & 90 & 312 & 426 \\
\hline Trcka & 0 & 1 & 1 & 0 & 0 & 1 \\
\hline Total & 15 & 23 & 38 & 171 & 323 & \\
\hline
\end{tabular}

Overall, my inventory disagrees with Kinworthy (2016), removing 73\% (312) of his features from my inventory. In contrast, I generally agree with Johnson's (2018) with only $8 \%$ (13) removed. Some of Kinworthy's features, 21\% (90) and most of Johnson's $76 \%$ (121) were reclassified from rock glaciers to FOI, because they do not extend out into the valley (Figure B-12a, b). Features that were excluded from my inventory do not show an over-steepened lower margins, indicative of possible internal ice, and others do not exhibit positive relief (Figure B-12c, d). 

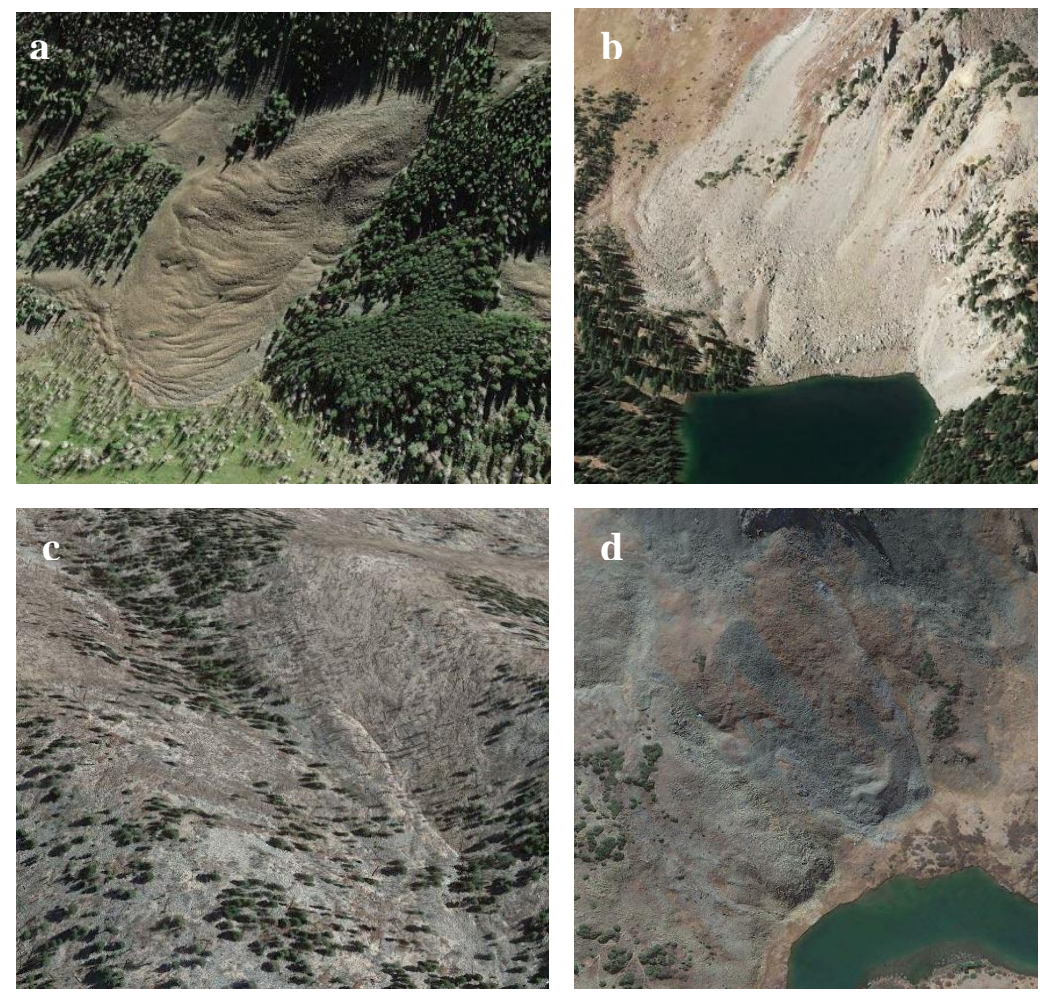

Figure B-12: : Examples of reclassified features, (a) a feature of interest identified by Kinworthy (2016) as a rock glacier (Sangre de Cristo Mountains, New Mexico, 35.8873 ${ }^{\circ}$, $\left.106.5603^{\circ}\right)$; (b) a feature of interest identified by both Kinworthy (2016) and Johnson (2018) as a rock glacier (Sangre de Cristo Mountains, New Mexico, $36.5335^{\circ}$, $\left.105.4243^{\circ}\right)$. Features that were excluded from my inventory, (c) bedrock identified by Kinworthy (2016) as a rock glacier (Gallinas Mountains, New Mexico, 33.5916,$-105.3757^{\circ}$ ); (d) bedrock identified by both Kinworthy (2016) and Johnson (2018) as a rock glacier (Sangre de Cristo Mountains, New Mexico, $\left.36.5627^{\circ},-105.4072^{\circ}\right)$. Image source: Google Earth Pro.

Kinworthy's rock glacier criteria are more detailed than my criteria (pg. 16). The major difference is that I specify that rock glaciers have to extend into the valley from the base of the valley wall or occupy the axis of a valley. In my view, this indicates significant movement and is different from a talus accumulation or a protalus rampart, 
both of which may contain ice but are not moving. This is the main difference between our classifications and results.

\section{Comparison with Legg's (2016) rock glacier inventor in Glacier National Park, Montana}

Legg, B.N., 2016, Rock glacier morphology and morphometry in Glacier National Park, northwest Montana, USA [MS thesis]: Texas State University, 64 p.

Legg (2016) inventoried rock glaciers in Glacier National Park, Montana, using

Google Earth and ArcMap (Figure B-13). The characteristics she used to identify rock glaciers include: "lobate, tongue (longer than wide), or spatulate shape (longer than wide with broadening at the base) with apparent ridges and furrows throughout the feature, and has access to a supply of talus". She grouped rock glaciers into two categories, active and relict. "Active rock glaciers have a steep front and a lack of vegetation, while relict rock glaciers have vegetation present, and a rounded collapsed front".

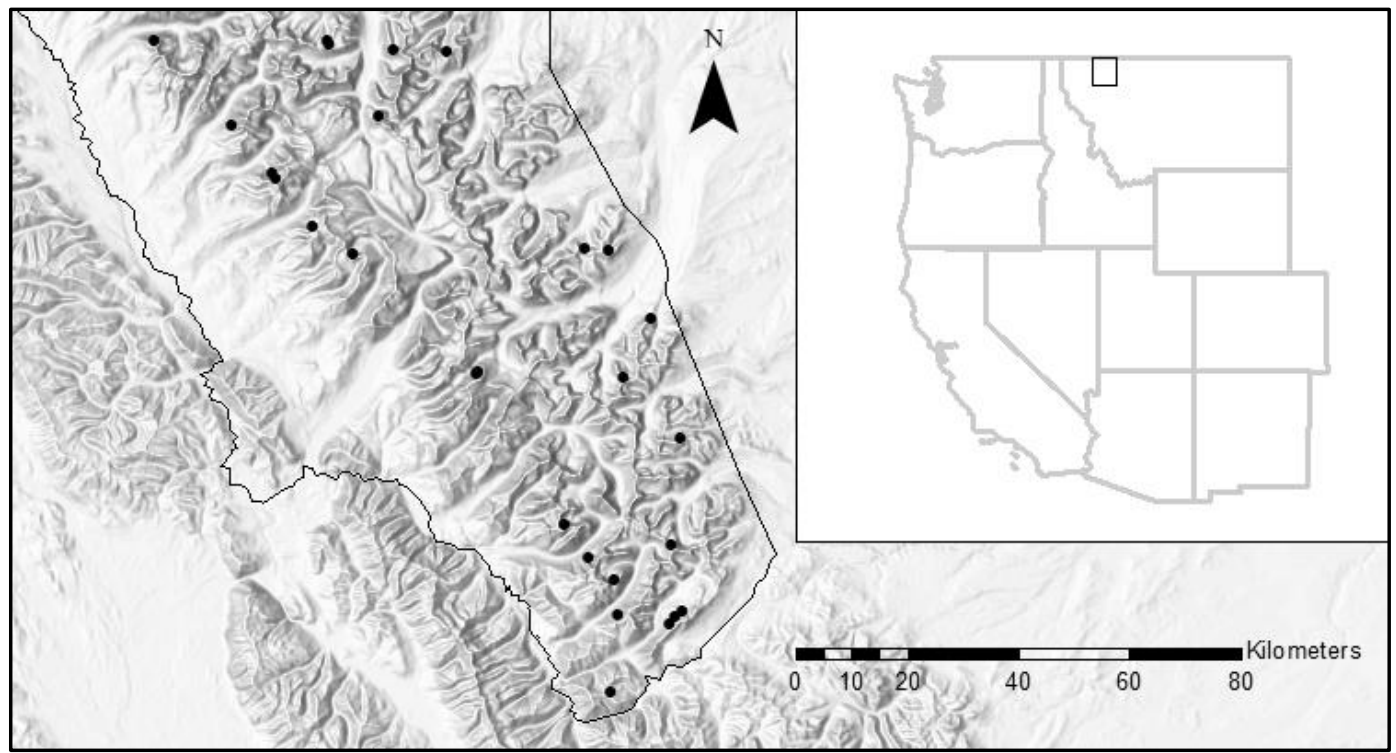

Figure B-13: The Legg (2016) rock glacier inventory (filled circles) within Glacier National Park (solid line) on a shaded relief map. 
She identified 27 features as rock glaciers compared to Johnson's (2018) 46; 17

features common to both (Table B-14). My re-examination of all 56 features identifies 7

rock glaciers, 36 features of interest, and 13 features eliminated (Table B-15).

Table B-14: The number of features identified as within Legg (2016) and Johnson (2018) inventories, rock glaciers that are included in only one inventory are Unique, those that are common to both inventories are Overlap.

\begin{tabular}{rrrr} 
& Unique & Overlap & Total \\
\cline { 2 - 4 } Johnson (2018) & 29 & 17 & 46 \\
Legg (2016) & 10 & 17 & 27
\end{tabular}

Table B-15: Reinterpretation Legg (2016) and Johnson (2018) inventories of Glacier National Park, Montana. The Rock Glaciers columns show my subcategorization and Removed are features that do not fit my criteria and are not Features of Interest. Numbers within the parenthesis in the Johnson row are the number of overlapping features between Johnson and Legg's inventories. The Trcka row indicates rock glaciers not identified by the other two inventories. Revised Total is total for the region (summing the numbers of Johnson, Legg, and Trcka minus the overlapping features).

\begin{tabular}{|c|c|c|c|c|c|c|}
\hline & \multicolumn{3}{|c|}{ Rock Glaciers } & \multirow{2}{*}{$\begin{array}{c}\text { Feature of } \\
\text { Interest }\end{array}$} & \multirow{2}{*}{ Removed } & \multirow{2}{*}{ Total } \\
\hline & Active & Inactive & Total & & & \\
\hline Johnson & $\begin{array}{ll}5 & (5)\end{array}$ & $0 \quad(0)$ & $5 \quad(5)$ & $28 \quad(11)$ & $13 \quad(1)$ & 46 \\
\hline Legg & 6 & 1 & 7 & 19 & 1 & 27 \\
\hline Trcka & 0 & 0 & 0 & 0 & 0 & 0 \\
\hline Total & 6 & 1 & 7 & 36 & 13 & \\
\hline
\end{tabular}

Overall, my inventory agrees with Legg's (2016), removing only one of her features from my inventory compared to 28\% (13) from Johnson (2018) (Table B-15). Most features in both inventories, 70\% (19) from Legg (2016) and 60\% (28) from Johnson (2018), were reclassified from rock glaciers to FOI because they do not extend out into the valley (Figure B-14a, b). Features that were excluded from my inventory do not show an over-steepened lower margins, indicative of possible internal ice, and others do not exhibit positive relief (Figure B-14c, d). 

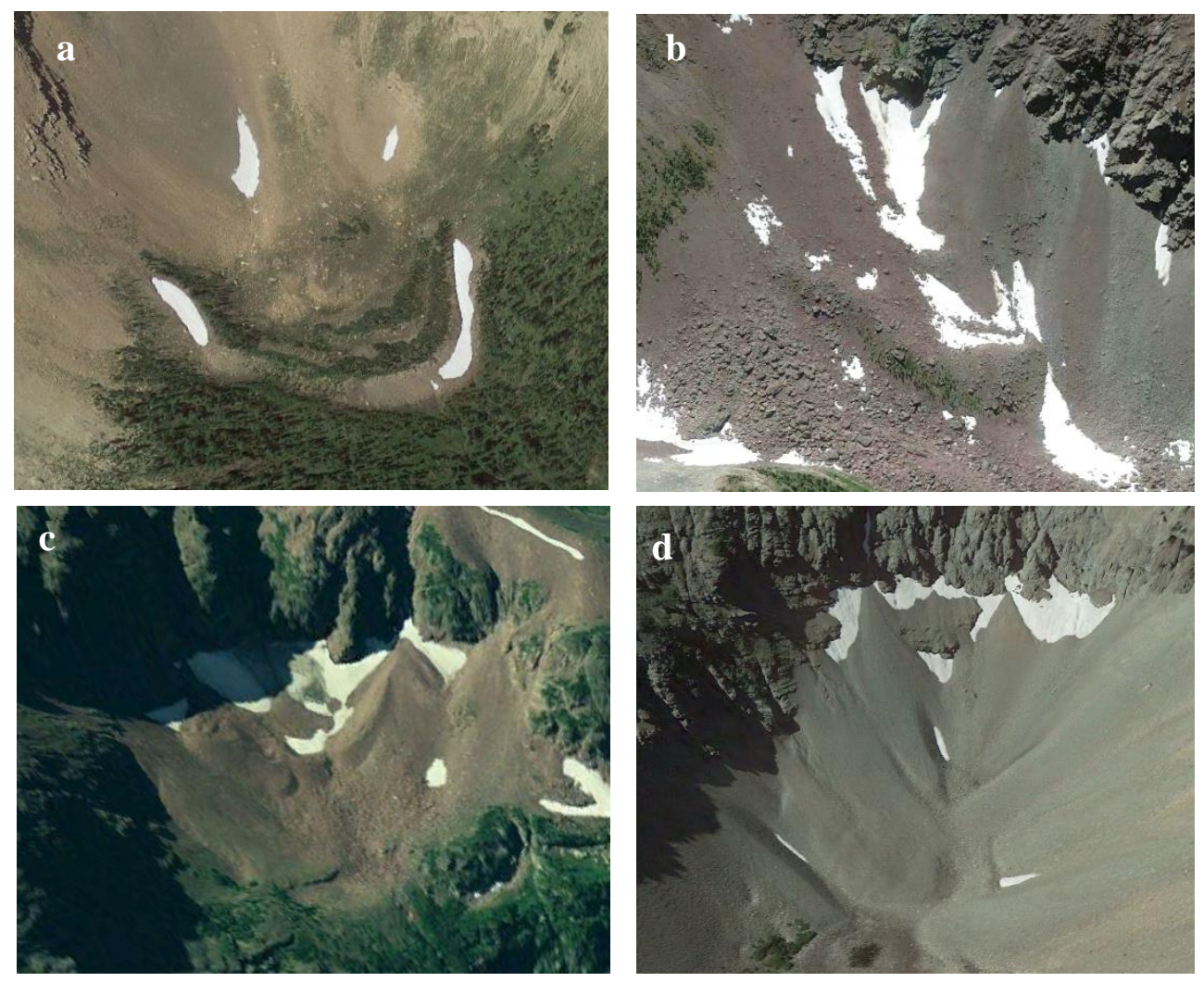

Figure B-14: Examples of reclassified features, (a) a feature of interest identified by Legg (2016) as a rock glacier (Lewis Range, Montana, $48.956711^{\circ},-113.967402^{\circ}$ ); (b) A feature of interest identified by both Legg (2016) and Johnson (2018) as a rock glacier (Lewis Range, Montana, $48.81295^{\circ},-114.0493^{\circ}$ ). Features that were excluded from my inventory, (c) a glacial moraine identified by Legg (2016) as a rock glacier (Lewis Range, Montana, $48.42324^{\circ},-113.4118^{\circ}$ ); (d) a talus slope identified by Johnson (2018) as a rock glacier (Lewis Range, Montana, 48.75359 ${ }^{\circ}$, 113.5266 ${ }^{\circ}$. Image source: Google Earth Pro.

Legg's 13 active rock glaciers, of which $46 \%$ (6) retain their classification the others were reclassified as inactive (1), or as FOI (28), or were eliminated (6; Table B-16). All of her relict rock glaciers (14) were reclassified as FOI (Figure B-15). We agree that the features are no longer moving but disagree on whether or not they are rock glaciers. 
Table B-16: A comparison of the activity level between mine and Legg's (2016) inventories. Columns indicate my classification and rows indicate Legg's.

\begin{tabular}{|c|c|c|c|c|c|c|}
\hline & \multicolumn{3}{|c|}{ Rock Glaciers } & \multirow{2}{*}{$\begin{array}{c}\text { Feature of } \\
\text { Interest }\end{array}$} & \multirow{2}{*}{ Removed } & \multirow{2}{*}{ Total } \\
\hline & Active & Inactive & Total & & & \\
\hline Legg-Active & 6 & 1 & 7 & 5 & 1 & 13 \\
\hline Legg-Relict & 0 & 0 & 0 & 14 & 0 & 14 \\
\hline
\end{tabular}

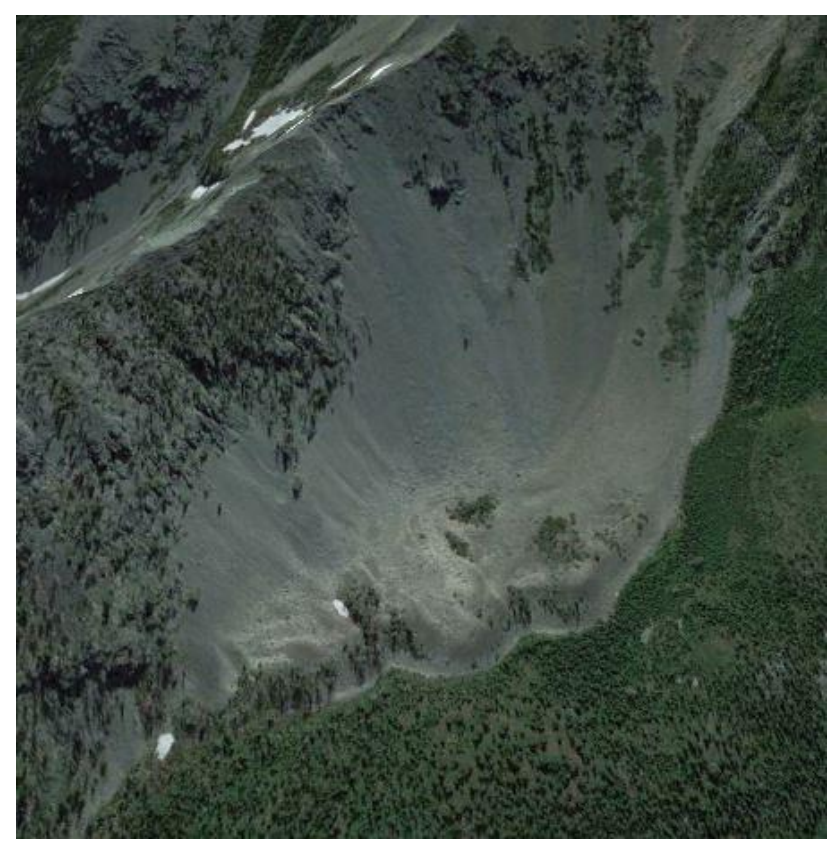

Figure B-15: An example of a rock glacier Legg classified as relict but I consider a feature of interest (Lewis Range, Montana, $48.347489^{\circ}$, $\left.113.404367^{\circ}\right)$. Image source: Google Earth Pro.

Legg's rock glacier criteria are similar to my criteria (pg. 16). The major difference is that I specify that rock glaciers have to extend into the valley from the base of the valley wall or occupy the axis of a valley In my view, this indicates significant movement and is different from a talus accumulation or a protalus rampart, both of which may contain ice but are not moving. Another difference is vegetation, although this does not affect differences in our inventories, Legg (2016) argues that active rock glaciers lack vegetation, but several studies show that sparse vegetation can be present (Liu et al., 
2013; Rangecroft et al., 2014; Uxa and Mida, 2017; Colucci et al., 2019; Millar and Westfall, 2019).

\section{Comparison with Johnson's (2018) rock glacier inventory of the contiguous United States}

Johnson, G., 2018, Rock glaciers of the contiguous United States: Spatial distribution, cryospheric context, and riparian vegetation [PhD thesis]: Portland State, $147 \mathrm{p}$.

Johnson (2018) inventoried the rock glaciers of the entire western United States using Google Earth Pro 7.17 and ESRI ArcMap 10.4 (Figure B-16). He initially mapped rock glaciers in regions populated with glaciers and perennial snowfields because of the known spatial association between the two (Janke, 2007; Haeberli et al., 1985). After some experience in the identification and characterization of rock glaciers, he extended the search to other mountain ranges. Johnson (2018) had only two criteria, "ridge and swale flow banding and over-steepened terminal and lateral slopes”. He grouped the rock glaciers into three categories: "Class 1 are definitely active and exhibit extensive ridge and swale banding, and over-steepened terminal slopes; Class 2 are probably active having some distinct ridge and swale flow banding, have distinct marginal slopes and terminal slopes are somewhat over-steepened; and Class 3 rock glaciers appear to be deflated". I did not have access to his sub-categorization and viewed all as simply rock glaciers. I used this inventory as a template for my inventory because it contains rock glacier locations throughout the entire western US. 


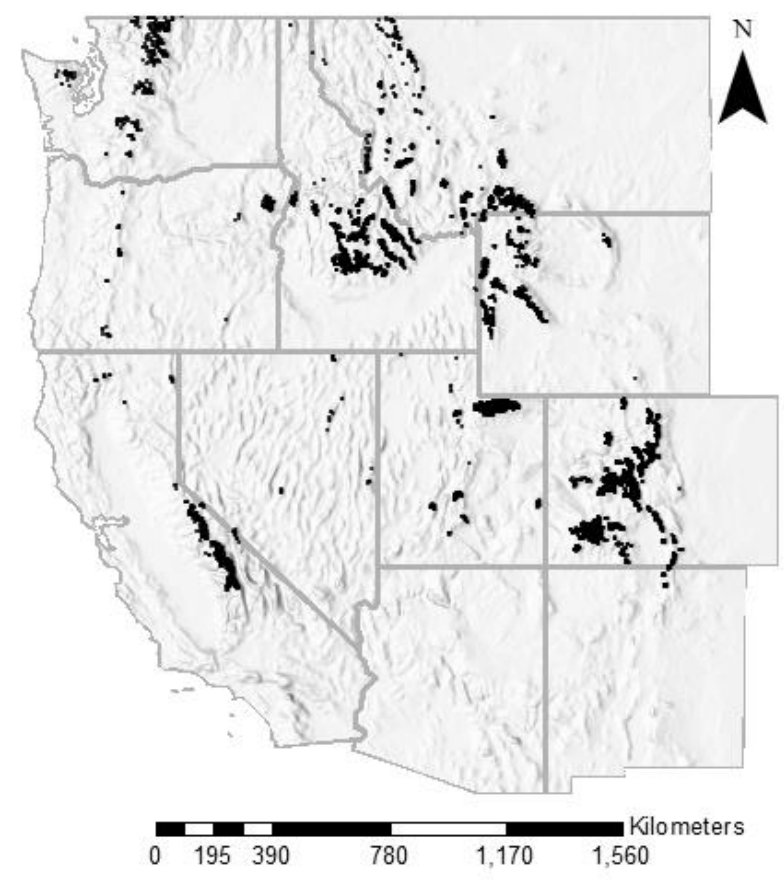

Figure B-16: The Johnson (2018) rock glacier inventory (filled circles) on a shaded relief map.

Johnson identified 10,046 features as rock glaciers (Table B-17). I reclassified those features as 2090 rock glaciers, 7169 features of interest, and 787 features eliminated. In addition, I added 159 new rock glaciers and 693 FOI to the Johnson's inventory (104 active, and 55 inactive) from my own search and from other inventories (Johnson et al., 2006; Florentine, 2011, Kinworthy, 2016; Legg, 2016; Riffle, 2018, Millar and Westfall, 2019). 
Table B-17: Reinterpretation of Johnson (2018) and Trcka (2020) inventories of the western United States. The Rock Glaciers columns show my subcategorization and Removed are features that do not fit my criteria and are not features of interest.

\begin{tabular}{|c|c|c|c|c|c|c|}
\hline \multicolumn{4}{|c|}{ Rock Glaciers } & \multirow{2}{*}{$\begin{array}{c}\text { Feature } \\
\text { of } \\
\text { Interest }\end{array}$} & \multirow{2}{*}{ Removed } & \multirow{2}{*}{ Total } \\
\hline & Active & Inactive & Total & & & \\
\hline & 146 & 630 & 2090 & 7169 & 787 & 10046 \\
\hline $\operatorname{Trc}$ & 1564 & 685 & 2249 & 7862 & 787 & 10898 \\
\hline
\end{tabular}

Most of his features 71\% (7169) were reclassified from rock glaciers to FOI.

Although, these features have ridges and furrows and steep fronts, they do not extend out into the valley (Figure B-17). I removed 7\% (787) of his features from the inventory because they do not show over-steepened lower margins, indicative of possible internal ice, and others do not exhibit positive relief (Figure B-17).
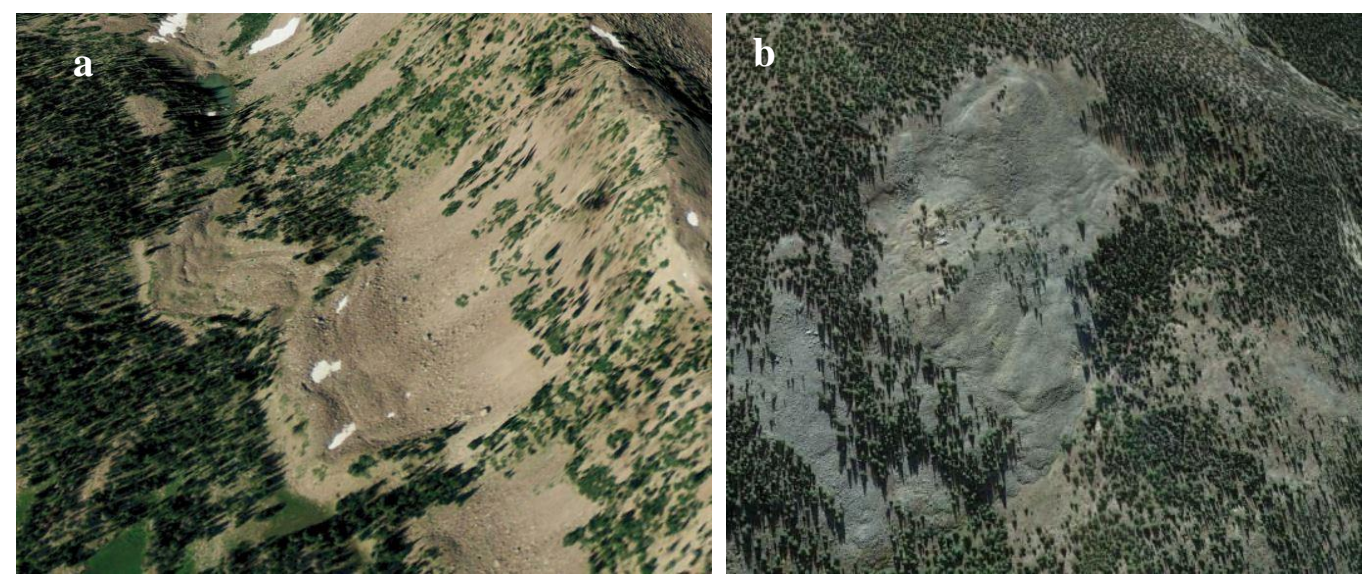

Figure B-17: (a) A feature of interest identified by Johnson (2018) as a rock

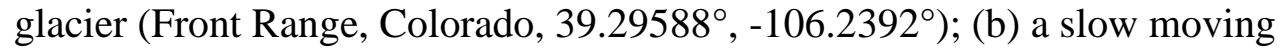
landslide (Adam Booth per comm) identified by Johnson (2018) as a rock glacier (Uinta Range, Utah, $40.78207^{\circ},-110.8523^{\circ}$ ). Both were removed from my inventory. Image source: Google Earth Pro.

Johnson's rock glacier criteria are more generalized than my criteria (pg. 16). The major difference is that I specify that rock glaciers have to extend into the valley from the 
base of the valley wall, which in my view, indicates significant movement and is different from a talus accumulation or a protalus rampart, both of which may contain ice but are not moving. This is the main difference between our classifications and results. Another difference in our classifications is that Johnson's (2018) classification is vague, only having two criteria. Having too little criteria can include features that are not necessarily rock glaciers into the inventory. 


\section{Appendix C Study Area/ Inventory of rock glaciers}

Table C-1: A comprehensive list of all rock glacier studies in the western US. Under the classification column A=active, I=inactive, $R=$ relict, $I n=I n t a c t$.

\begin{tabular}{llll} 
Reference & Location & Class & Used \\
\hline White, 1979 & San Juan Mountains, CO & A, I & No \\
Vick, 1981 & Mosquito Range, CO & A, I No \\
Janke, 2007 & Front Range, CO & A, I, R No \\
Refsnider and Brugger, 2007 & Elk Mountains, CO & In, R No \\
Johnson et al., 2007 & Lemhi Range, ID & A, I, R Yes \\
Millar and Westfall, 2008 & Sierra Nevada, CA & A, I, R Yes \\
Seligman, 2009 & Absaroka/ Beartooth Ranges, MT & A, I, R No \\
Van Hoesen and Orndorff, 2011 & Snake Range, NV & None No \\
Gustin, 2013 & Tabacco Root Mountains, MT & None No \\
Liu et al., 2013 & Sierra Nevada, CA & A & Yes \\
Florentine et al., 2014 & Absaroka/ Beartooth Ranges, MT & None Yes \\
Kinworthy, 2016 & New Mexico & A, I, R Yes \\
Legg, 2016 & Glacier National Park, MT & A, R Yes \\
Monroe, 2018 & Unita Mountains, UT & None No \\
Johnson, 2018 & USA & A, I, R Yes \\
Millar and Westfall, 2019 & Great Basin & A, I, R Yes
\end{tabular}

Table C-2: Summary of the elevation and area of rock glacier for each state and mountain range. Max represents maximum, min is minimum.

\begin{tabular}{lrrrrrrr} 
& & \multicolumn{3}{c}{ Elevation $(\mathrm{m})$} & \multicolumn{3}{c}{ Area $\left(\mathrm{km}^{2}\right)$} \\
\cline { 3 - 8 } State/Range & Number & Max & Min & Mean & Mean & Median & Total \\
\hline California & $\mathbf{2 6 2}$ & $\mathbf{4 1 1 6}$ & $\mathbf{2 2 5 8}$ & $\mathbf{3 4 9 7}$ & $\mathbf{0 . 2 4}$ & $\mathbf{0 . 1 8}$ & $\mathbf{6 1 . 9 0}$ \\
Sierra Nevada & 255 & 4116 & 2497 & 3500 & 0.24 & 0.18 & 60.28 \\
White Mts. & 6 & 3813 & 3157 & 3572 & 0.22 & 0.14 & 1.34 \\
Cascades-Trinity Alps & 1 & 2373 & 2258 & 2315 & 0.27 & 0.27 & 0.27 \\
\hline Colorado & $\mathbf{9 6 3}$ & $\mathbf{4 1 5 2}$ & $\mathbf{2 2 9 9}$ & $\mathbf{3 6 3 3}$ & $\mathbf{0 . 1 7}$ & $\mathbf{0 . 1 1}$ & $\mathbf{1 5 9 . 2 5}$ \\
Front Range & 114 & 3883 & 3137 & 3522 & 0.15 & 0.10 & 17.15 \\
Mosquito-Gore Ranges & 73 & 3995 & 3308 & 3651 & 0.15 & 0.12 & 10.67 \\
Sawatch Range & 194 & 4152 & 3121 & 3684 & 0.16 & 0.11 & 30.42 \\
Elk-West Elk Mts. & 186 & 4013 & 2299 & 3611 & 0.21 & 0.14 & 38.67 \\
Park Range & 20 & 3499 & 3001 & 3290 & 0.13 & 0.10 & 2.63 \\
Flat Tops Range & 30 & 3593 & 3207 & 3406 & 0.13 & 0.10 & 3.88 \\
Sangre de Christo Mts. & 54 & 3953 & 2731 & 3629 & 0.19 & 0.11 & 10.00 \\
San Juan Mts. & 292 & 4045 & 3117 & 3699 & 0.16 & 0.10 & 45.83
\end{tabular}




\begin{tabular}{|c|c|c|c|c|c|c|c|}
\hline Idaho & 351 & 3415 & 2198 & 2866 & 0.14 & 0.11 & 50.25 \\
\hline Lemhi Range & 84 & 3112 & 2326 & 2765 & 0.13 & 0.09 & 11.14 \\
\hline Henrys lake-Eastern & & & & & & & \\
\hline Centennial Mts. & 2 & 2950 & 2781 & 2872 & 0.26 & 0.26 & 0.51 \\
\hline Bitterroot Range & 1 & 2362 & 2302 & 2329 & 0.06 & 0.06 & 0.06 \\
\hline Beaverhead Range & 3 & 3006 & 2679 & 2887 & 0.13 & 0.13 & 0.39 \\
\hline $\begin{array}{l}\text { Lost River Range } \\
\text { Boise-Sawtooth-Pioneer }\end{array}$ & 49 & 3415 & 2486 & 2990 & 0.15 & 0.11 & 7.12 \\
\hline Ranges & 178 & 3351 & 2413 & 2940 & 0.15 & 0.11 & 27.11 \\
\hline Salmon River Mts. & 33 & 2909 & 2198 & 2571 & 0.11 & 0.10 & 3.76 \\
\hline Seven Devils Range & 1 & 2492 & 2388 & 2439 & 0.17 & 0.17 & 0.17 \\
\hline $\begin{array}{l}\text { Montana } \\
\text { Gallatin-Madison-Gravelly }\end{array}$ & 324 & 3701 & 1926 & 2845 & 0.25 & 0.17 & 80.01 \\
\hline $\begin{array}{l}\text { Ranges } \\
\text { Beartooth Mts.-Absaroka }\end{array}$ & 51 & 3189 & 2464 & 2892 & 0.24 & 0.16 & 12.43 \\
\hline Range & 181 & 3701 & 2119 & 2932 & 0.30 & 0.22 & 53.63 \\
\hline Lewis Range & 10 & 2380 & 1926 & 2158 & 0.12 & 0.08 & 1.25 \\
\hline Swan Range & 4 & 2553 & 1961 & 2220 & 0.13 & 0.16 & 0.54 \\
\hline Bitterroot Range & 3 & 2832 & 2281 & 2557 & 0.23 & 0.24 & 0.69 \\
\hline Sapphire Range & 27 & 2961 & 2187 & 2628 & 0.18 & 0.18 & 4.79 \\
\hline Little Belt Mts. & 1 & 2507 & 2277 & 2378 & 0.54 & 0.54 & 0.54 \\
\hline Crazy-Big Belt Mts. & 15 & 3061 & 2619 & 2818 & 0.13 & 0.12 & 1.96 \\
\hline Tobacco Root Range & 11 & 2959 & 2501 & 2772 & 0.10 & 0.08 & 1.11 \\
\hline Pioneer Mts. & 9 & 2970 & 2634 & 2823 & 0.17 & 0.12 & 1.51 \\
\hline Beaverhead Mts. & 12 & 3028 & 2548 & 2838 & 0.13 & 0.09 & 1.56 \\
\hline New Mexico & 26 & 3782 & 2348 & 3091 & 0.11 & 0.10 & 2.83 \\
\hline $\begin{array}{l}\text { Sangre de Cristo Mts. } \\
\text { Gallinas-Capitan-Carrizo }\end{array}$ & 14 & 3782 & 3133 & 3527 & 0.12 & 0.08 & 1.75 \\
\hline Mts. & 10 & 2813 & 2348 & 2543 & 0.10 & 0.11 & 1.04 \\
\hline Magdalena-San Mateo Mts. & 2 & 2825 & 2690 & 2779 & 0.02 & 0.02 & 0.05 \\
\hline $\begin{array}{l}\text { Nevada } \\
\text { Toiyabe-Toquima-Silver }\end{array}$ & 13 & 3507 & 2082 & 2957 & 0.21 & 0.11 & 2.69 \\
\hline Peak Ranges & 5 & 3285 & 2082 & 2873 & 0.31 & 0.11 & 1.53 \\
\hline Snake Mts. & 1 & 3507 & 3254 & 3368 & 0.32 & 0.32 & 0.32 \\
\hline Ruby Mts. & 5 & 3152 & 2836 & 2970 & 0.10 & 0.09 & 0.49 \\
\hline Jarbridge Mts. & 2 & 3072 & 2836 & 2928 & 0.18 & 0.18 & 0.35 \\
\hline Oregon & 20 & 2834 & 2185 & 2519 & 0.10 & 0.08 & 2.00 \\
\hline Steens Mts. & 1 & 2833 & 2678 & 2755 & 0.11 & 0.11 & 0.11 \\
\hline Wallowa Mts. & 16 & 2834 & 2185 & 2526 & 0.10 & 0.08 & 1.61 \\
\hline Blue Mts. & 1 & 2399 & 2345 & 2374 & 0.09 & 0.09 & 0.09 \\
\hline Cascade Range & 2 & 2584 & 2273 & 2425 & 0.09 & 0.09 & 0.19 \\
\hline Utah & 73 & 3768 & 2682 & 3282 & 0.14 & 0.10 & 10.46 \\
\hline
\end{tabular}




\begin{tabular}{lrrrrrrr} 
Raft River-Bear River & & & & & & \\
Ranges & 2 & 2846 & 2682 & 2778 & 0.06 & 0.06 & 0.12 \\
Wasatch Range & 13 & 3304 & 2913 & 3097 & 0.18 & 0.16 & 2.36 \\
Tushar-Escalante-Boulder & & & & & & & \\
Mts. & 14 & 3437 & 2946 & 3204 & 0.09 & 0.08 & 1.24 \\
Uinta Mountain's & 34 & 3768 & 2956 & 3408 & 0.16 & 0.12 & 5.60 \\
La Sal Mts. & 10 & 3608 & 2993 & 3307 & 0.11 & 0.10 & 1.14 \\
\hline Washington & $\mathbf{3 8}$ & $\mathbf{2 6 0 0}$ & $\mathbf{1 6 1 8}$ & $\mathbf{2 0 7 9}$ & $\mathbf{0 . 1 8}$ & $\mathbf{0 . 1 7}$ & $\mathbf{6 . 7 2}$ \\
Cascade Range-Southern & 7 & 2600 & 1736 & 1949 & 0.25 & 0.24 & 1.74 \\
Cascade Range-Northern & 31 & 2571 & 1618 & 2108 & 0.16 & 0.16 & 4.98 \\
\hline Wyoming & $\mathbf{1 7 9}$ & $\mathbf{3 8 9 8}$ & $\mathbf{2 5 2 7}$ & $\mathbf{3 1 7 5}$ & $\mathbf{0 . 2 5}$ & $\mathbf{0 . 1 8}$ & $\mathbf{4 5 . 0 9}$ \\
Beartooth Mts.-Absaroka & & & & & & & \\
Range & 44 & 3502 & 2574 & 3010 & 0.32 & 0.26 & 13.95 \\
Bighorn Mts. & 4 & 3558 & 3142 & 3331 & 0.27 & 0.20 & 1.07 \\
Owl Creek Mts. & 37 & 3590 & 2670 & 3289 & 0.22 & 0.18 & 8.16 \\
Teton Range & 22 & 3429 & 2627 & 3009 & 0.30 & 0.23 & 6.54 \\
Gros Ventre Range & 14 & 3252 & 2892 & 3108 & 0.17 & 0.15 & 2.40 \\
Wind River Range & 50 & 3898 & 2914 & 3358 & 0.23 & 0.14 & 11.65 \\
Wyoming Range & 8 & 3189 & 2527 & 2912 & 0.17 & 0.17 & 1.32 \\
\hline Total & $\mathbf{2 2 4 9}$ & $\mathbf{4 1 5 2}$ & $\mathbf{1 6 1 8}$ & $\mathbf{3 2 9 0}$ & $\mathbf{0 . 1 9}$ & $\mathbf{0 . 1 3}$ & $\mathbf{4 2 1 . 2}$
\end{tabular}




\section{Appendix D Topographical Characteristics}

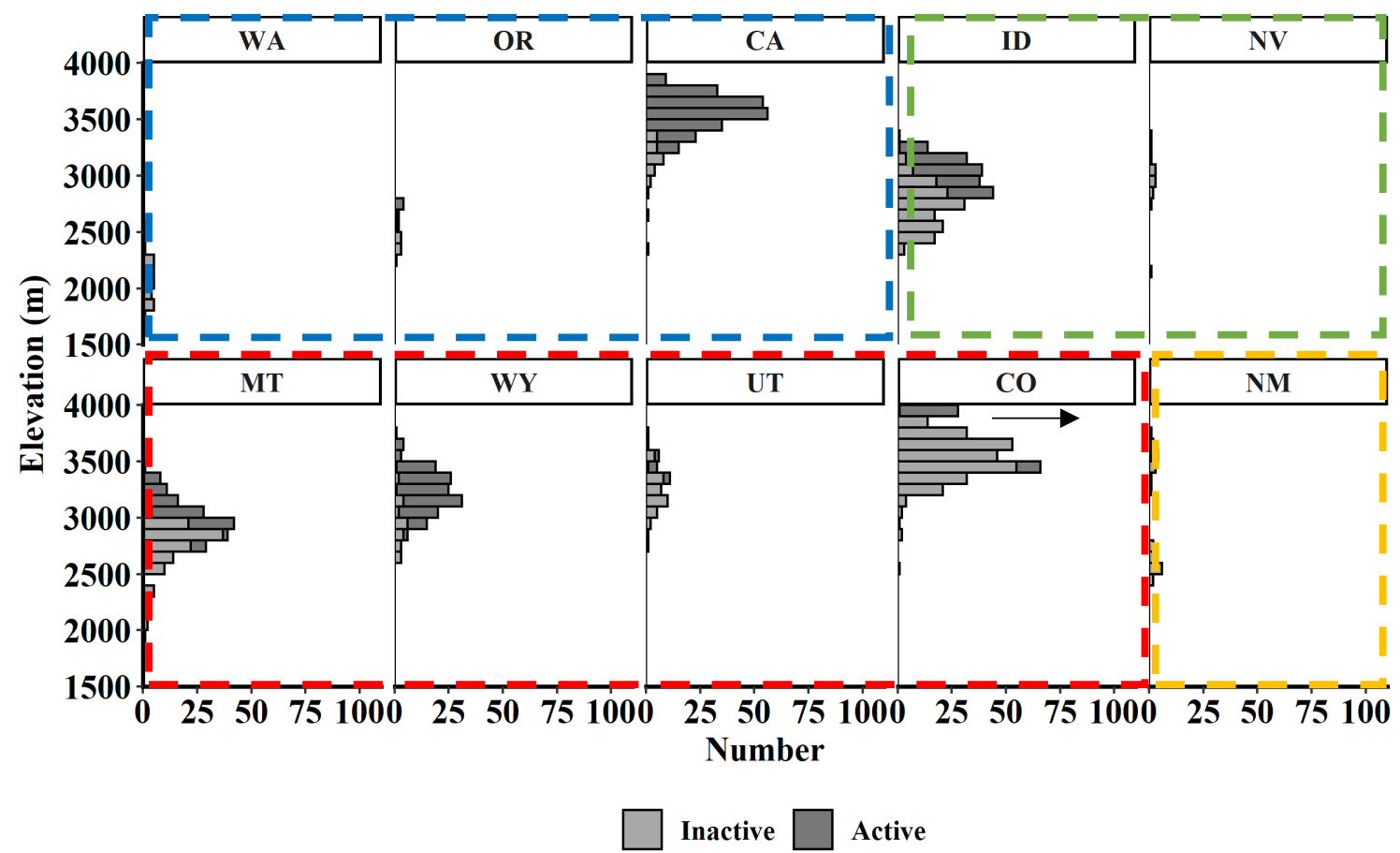

Figure D-1: Histograms of rock glacier elevation per state. Dashed borders represent states bordered in a north-south direction.

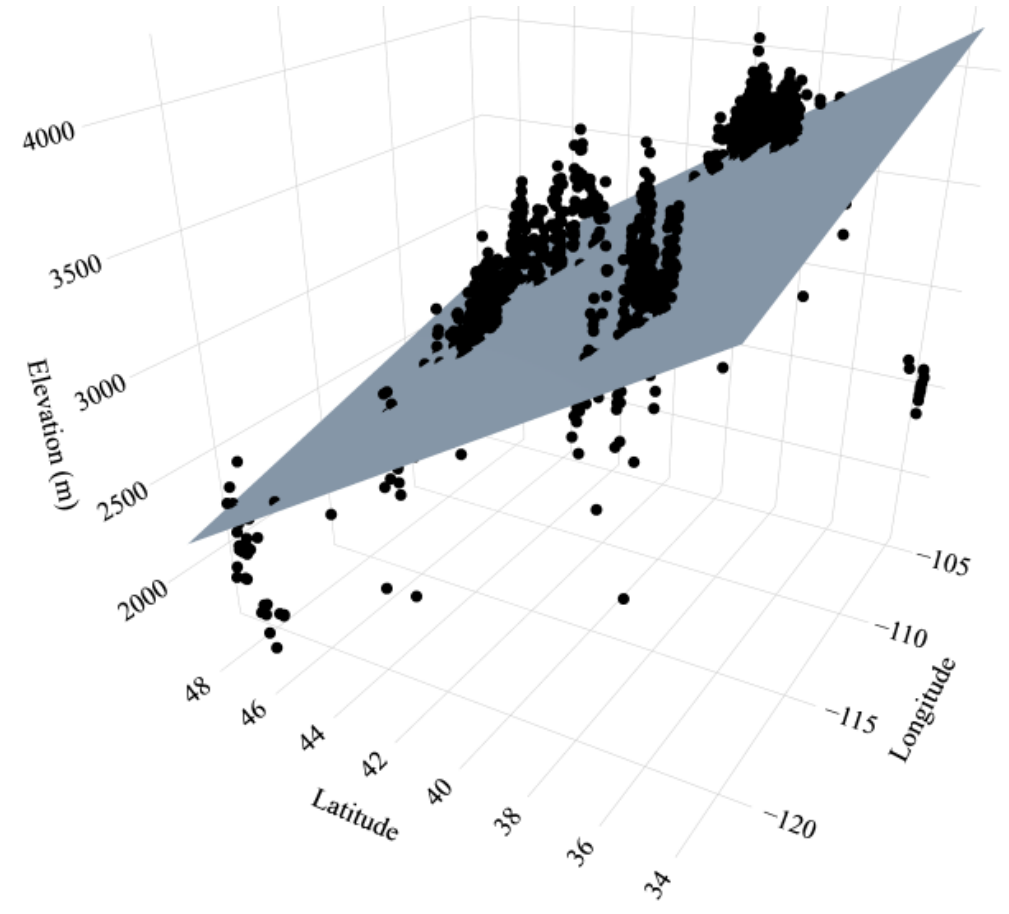

Figure D-2: Mean elevation of rock glaciers in relation to its location. 


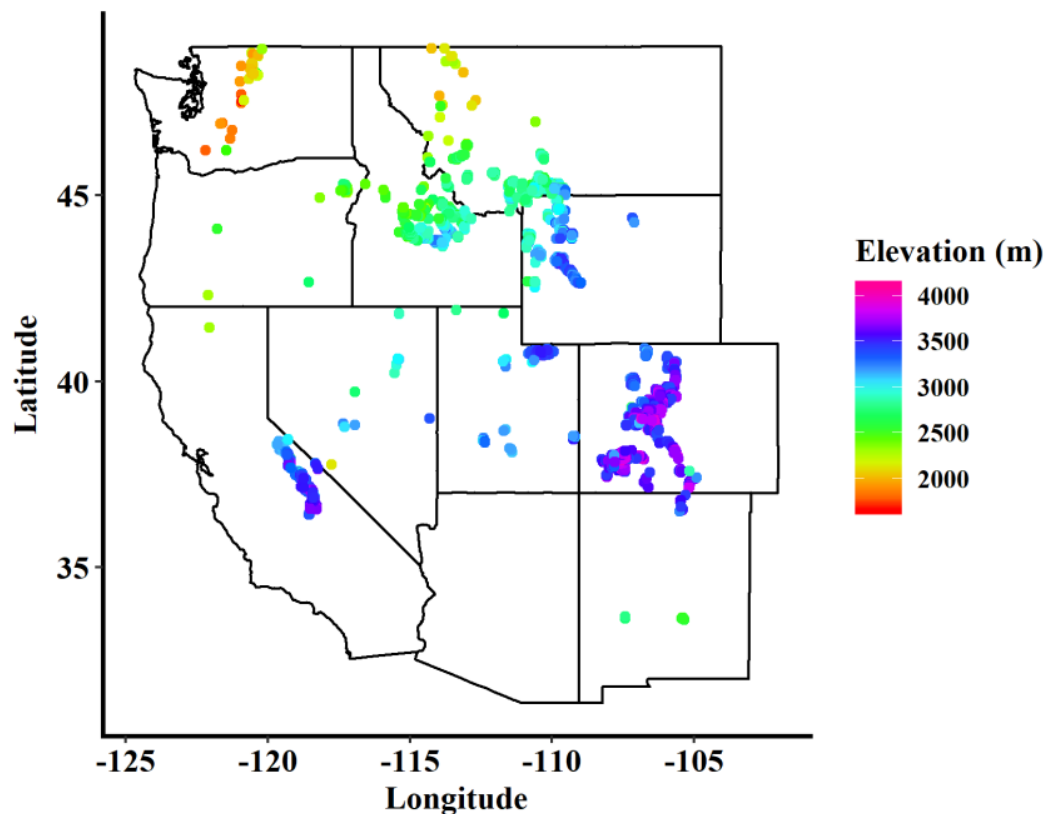

Figure D-3: Spatial distribution of rock glaciers, color represents elevation.

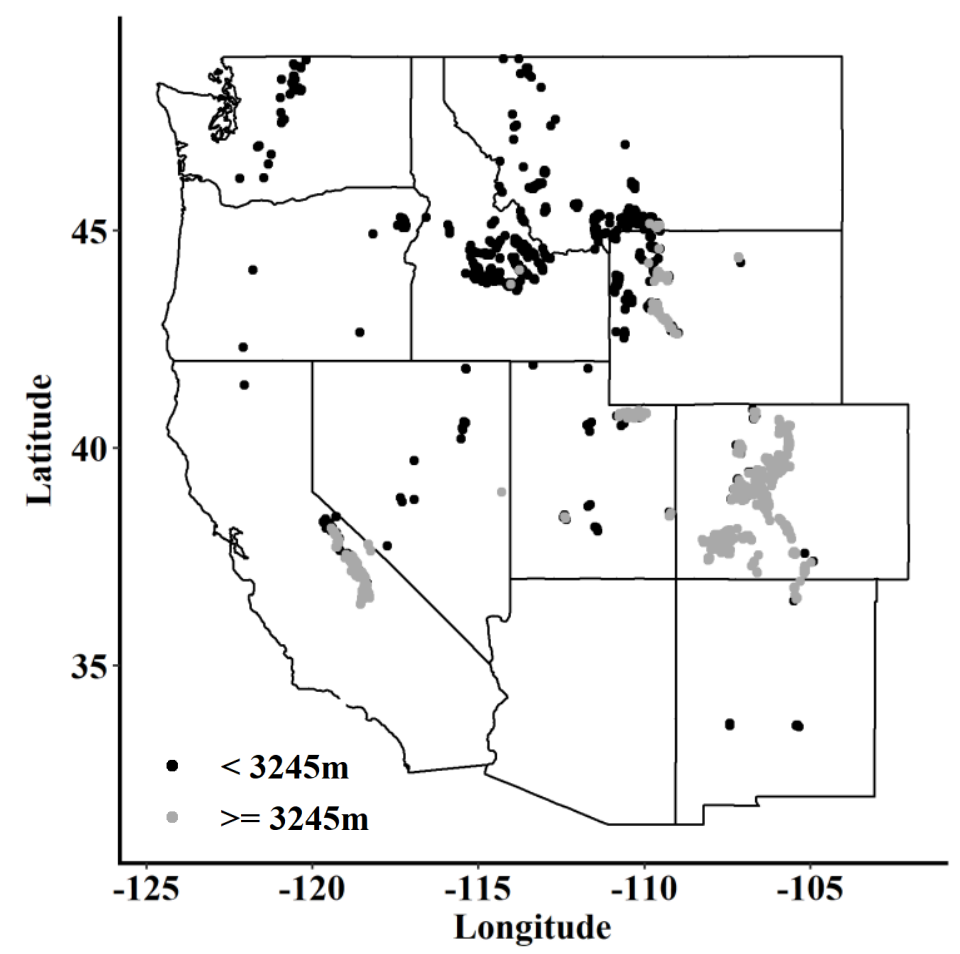

Figure D-4: The distribution of rock glaciers with high elevations $(>=3245 \mathrm{~m})$ and low elevations $(<3245 \mathrm{~m})$ across the western United States. 

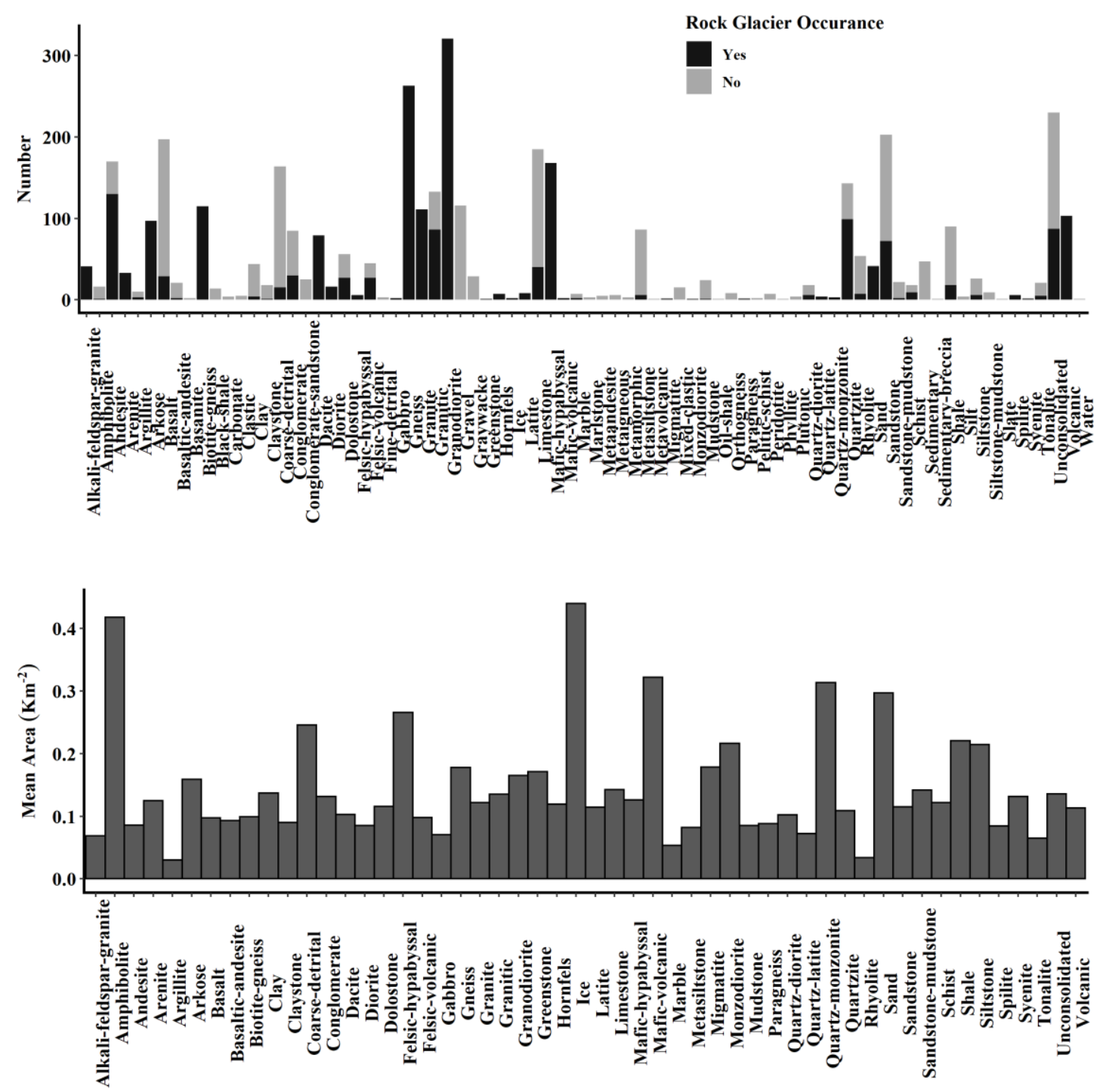

Figure D-5: Geology of rock glaciers; top- the major rock types of regions with rock glaciers (black) and without (gray), bottom- the total rock glacier area of the major rock types. 


\section{Appendix E Climate}

Table E-1: Average climate characteristics of rock glaciers in each state. Temp is temperature in ${ }^{\circ} \mathrm{C}$ and Precip is precipitation in $\mathrm{mm}$.

\begin{tabular}{lrrrrrr} 
State & Winter & Winter & \multicolumn{1}{l}{ Sum } & \multicolumn{1}{l}{ Sum } & Annual & Annual \\
CO & 653 & -7.4 & 277 & 7.8 & 1095 & -0.9 \\
NM & 348 & -1.6 & 345 & 12.2 & 806 & 4.3 \\
MT & 646 & -7.1 & 300 & 8.4 & 1161 & -0.6 \\
CA & 949 & -5.1 & 76 & 7.6 & 1136 & 0.2 \\
OR & 1173 & -4.5 & 183 & 9.0 & 1571 & 1.1 \\
ID & 643 & -6.3 & 196 & 9.4 & 1009 & 0.3 \\
WA & 1263 & -4.5 & 234 & 9.1 & 1763 & 1.2 \\
UT & 595 & -5.7 & 251 & 9.4 & 1017 & 0.7 \\
WY & 626 & -7.7 & 243 & 8.0 & 1062 & -1.1 \\
NV & 505 & -3.8 & 134 & 11.1 & 776 & 2.4
\end{tabular}



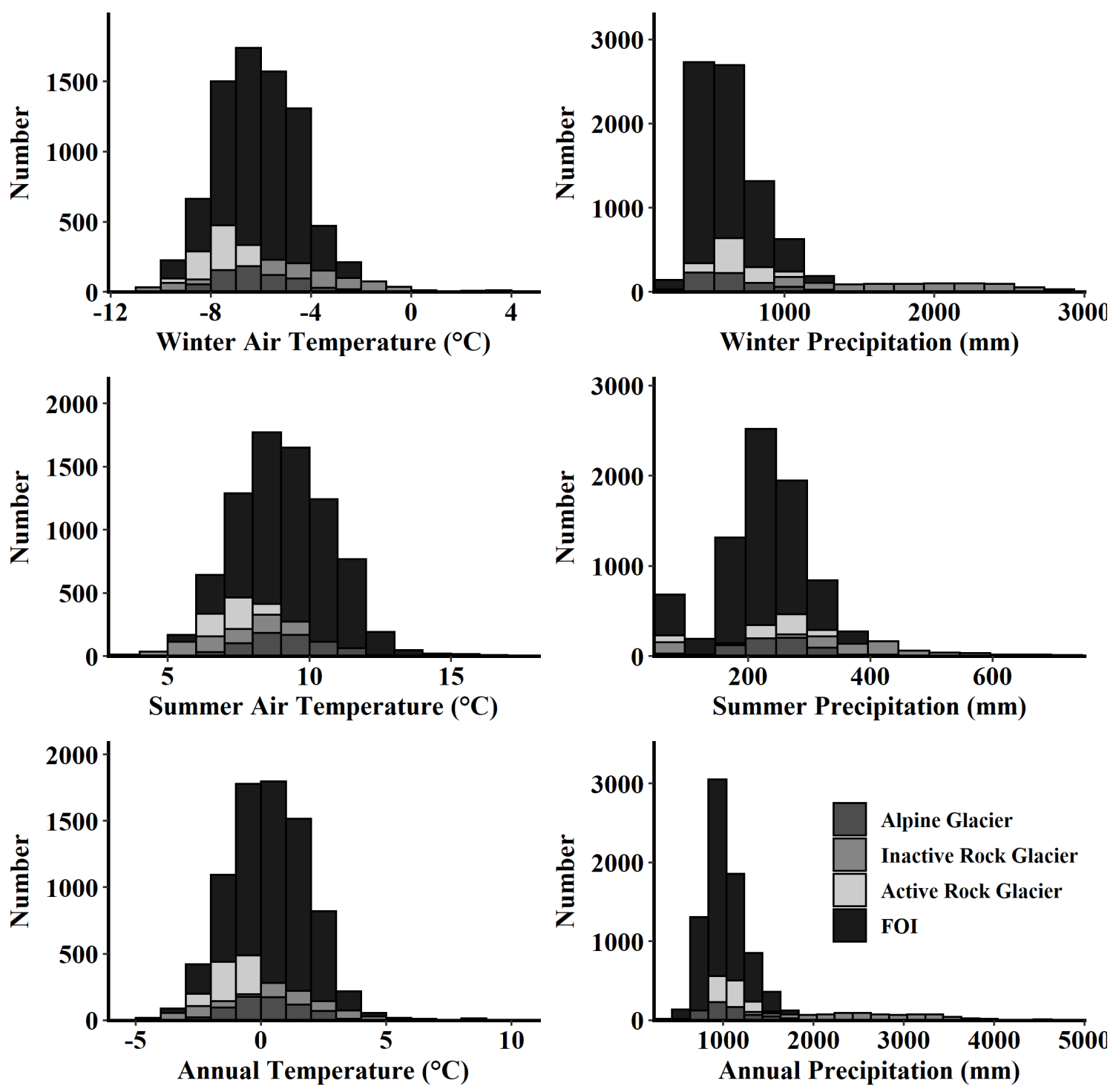

Figure E-1: Overlapping histograms of active and inactive rock glaciers, features of interest, and alpine glaciers for seasonal and annual temperatures and precipitation 


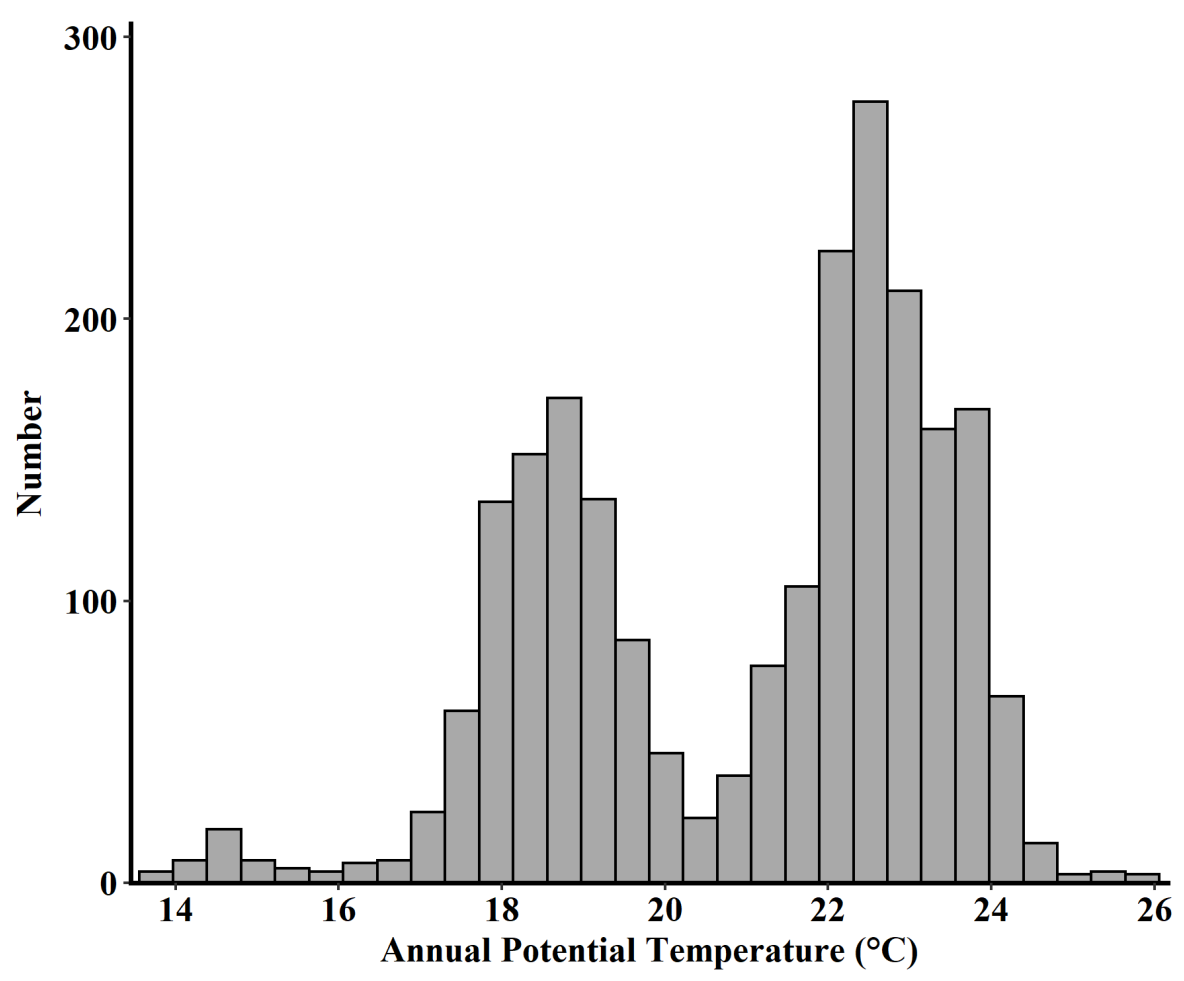

Figure E-2: Histogram of the annual potential temperature of the rock glaciers in the western US

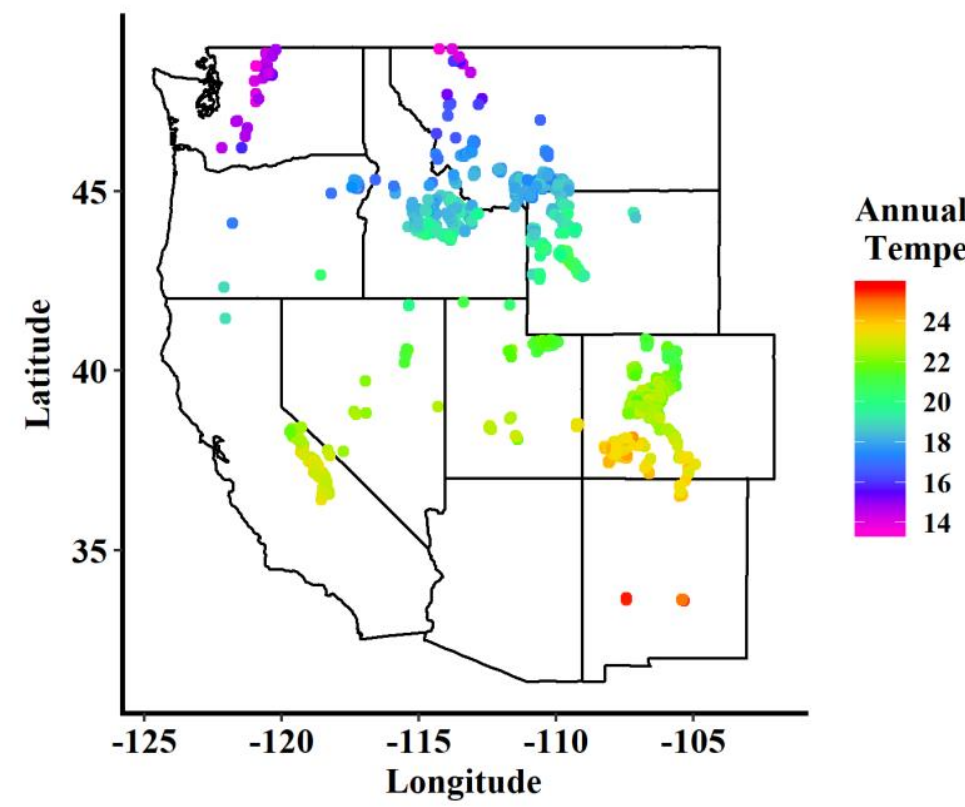

Figure E-3: Spatial distribution of rock glaciers, color represents potential summer air temperature. 


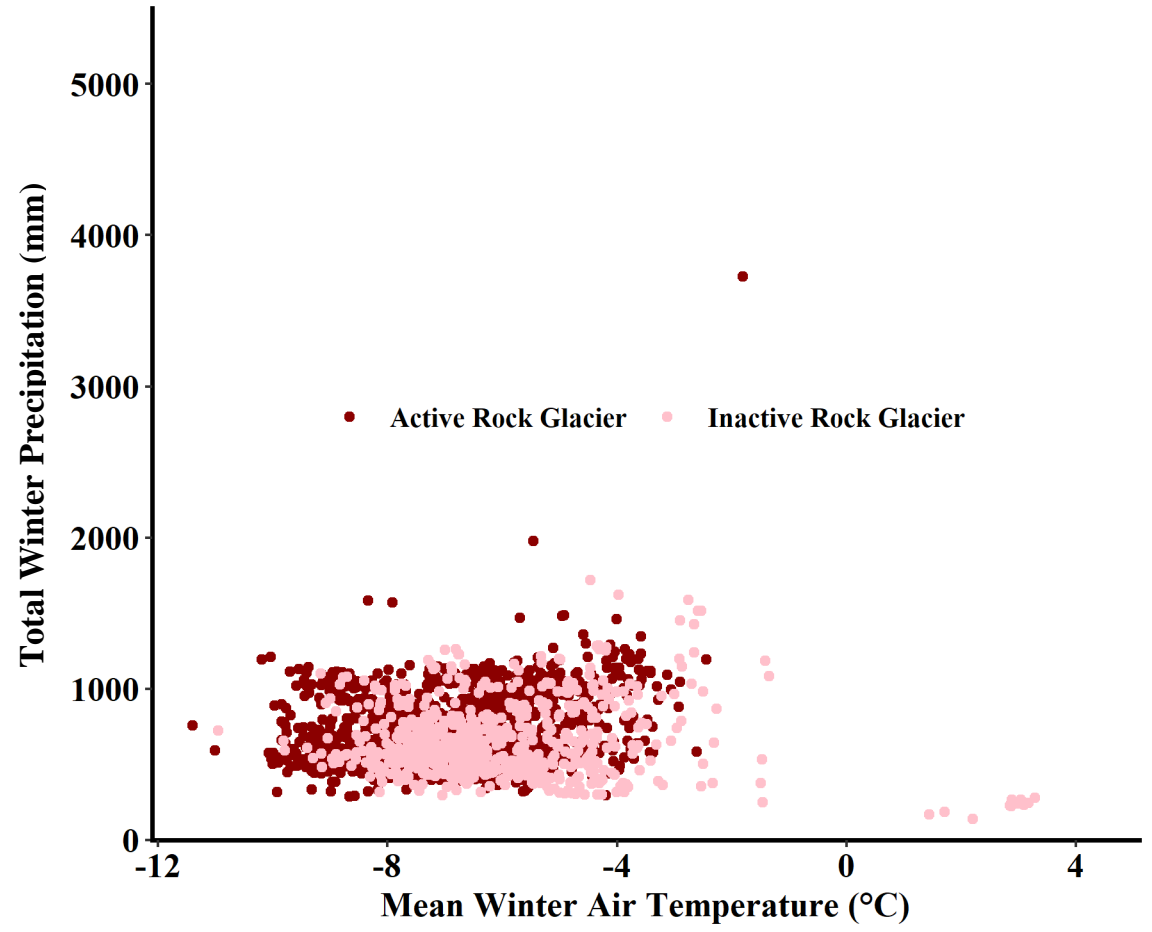

Figure E-4: Total winter precipitation and winter air temperature of active and inactive rock glaciers

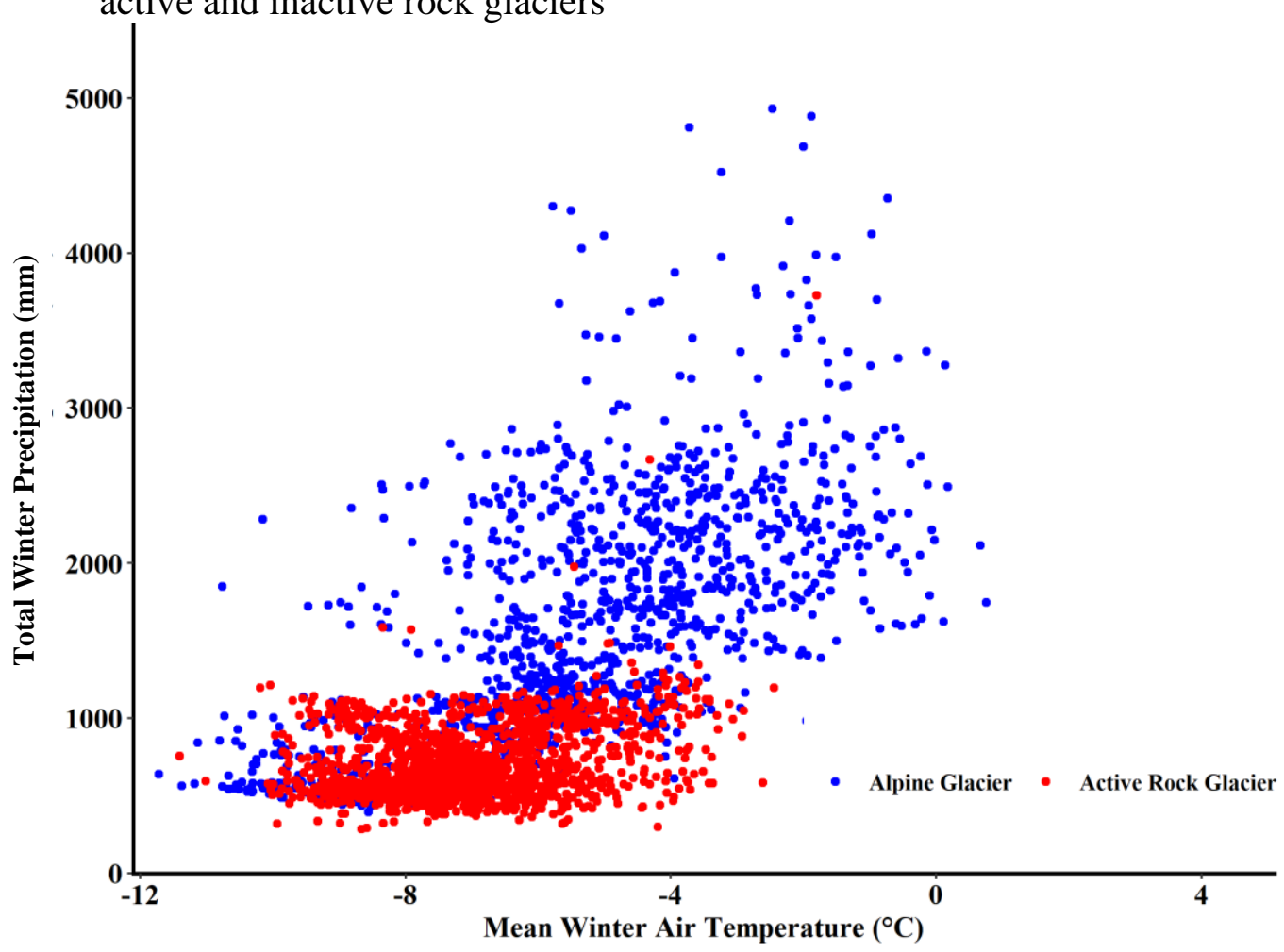

Figure E-5: Total winter precipitation and winter air temperature of alpine glaciers and rock glaciers. 


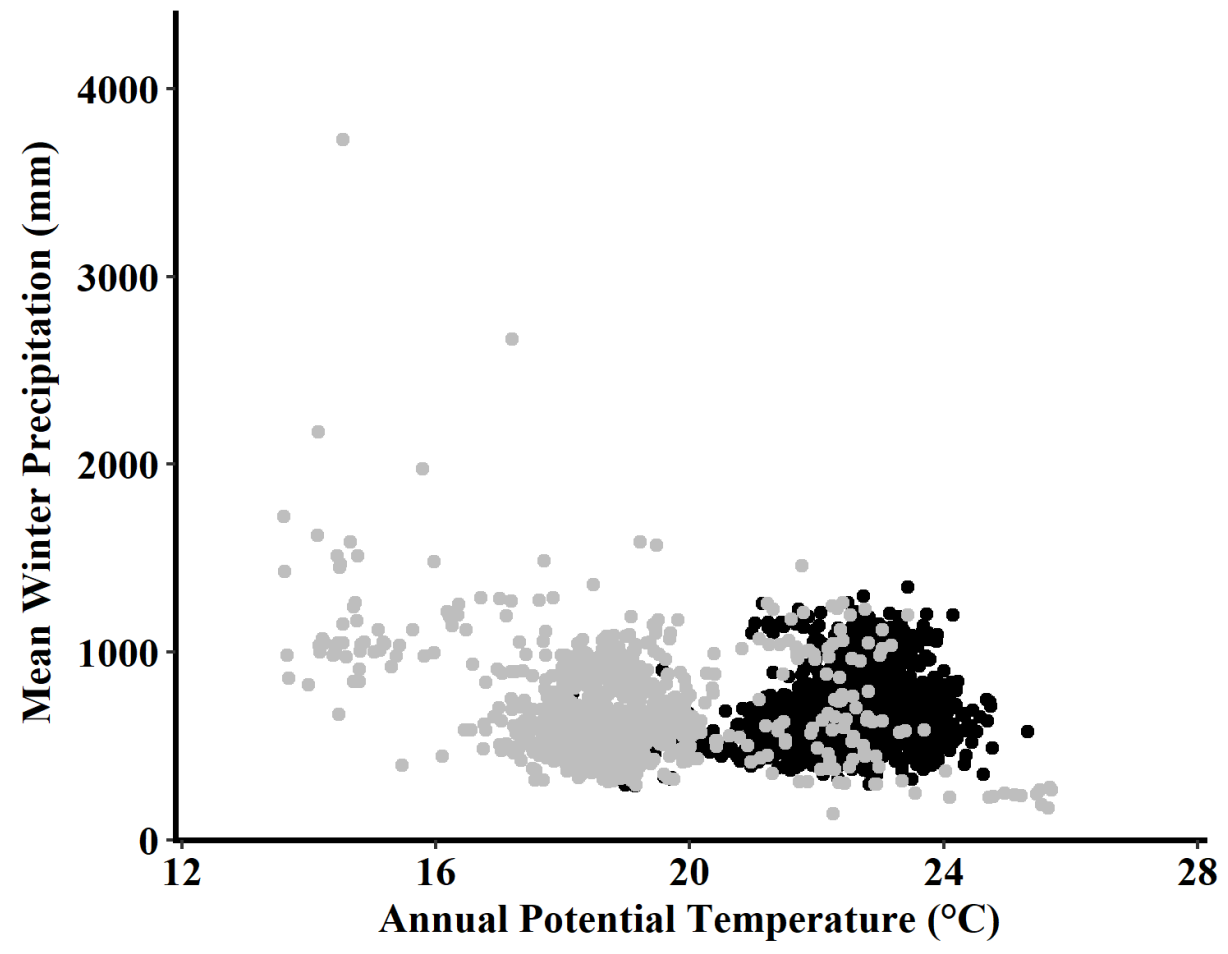

Figure E-6: Climate of the PNW (gray) and elsewhere (black) of rock glaciers.

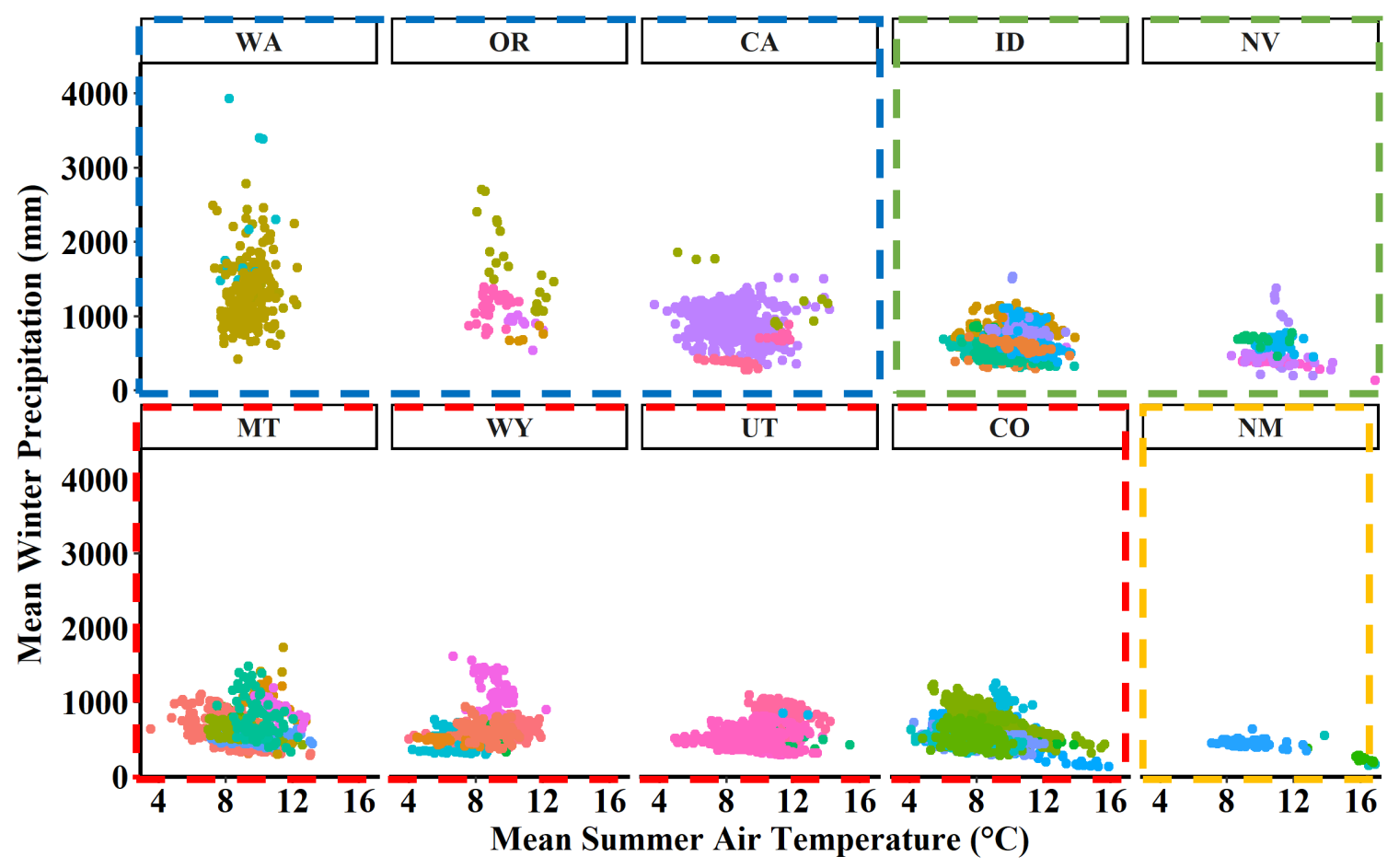

Figure E-7: Winter precipitation and summer temperature of features of interest for each state. Shapes and color represent mountain ranges. 

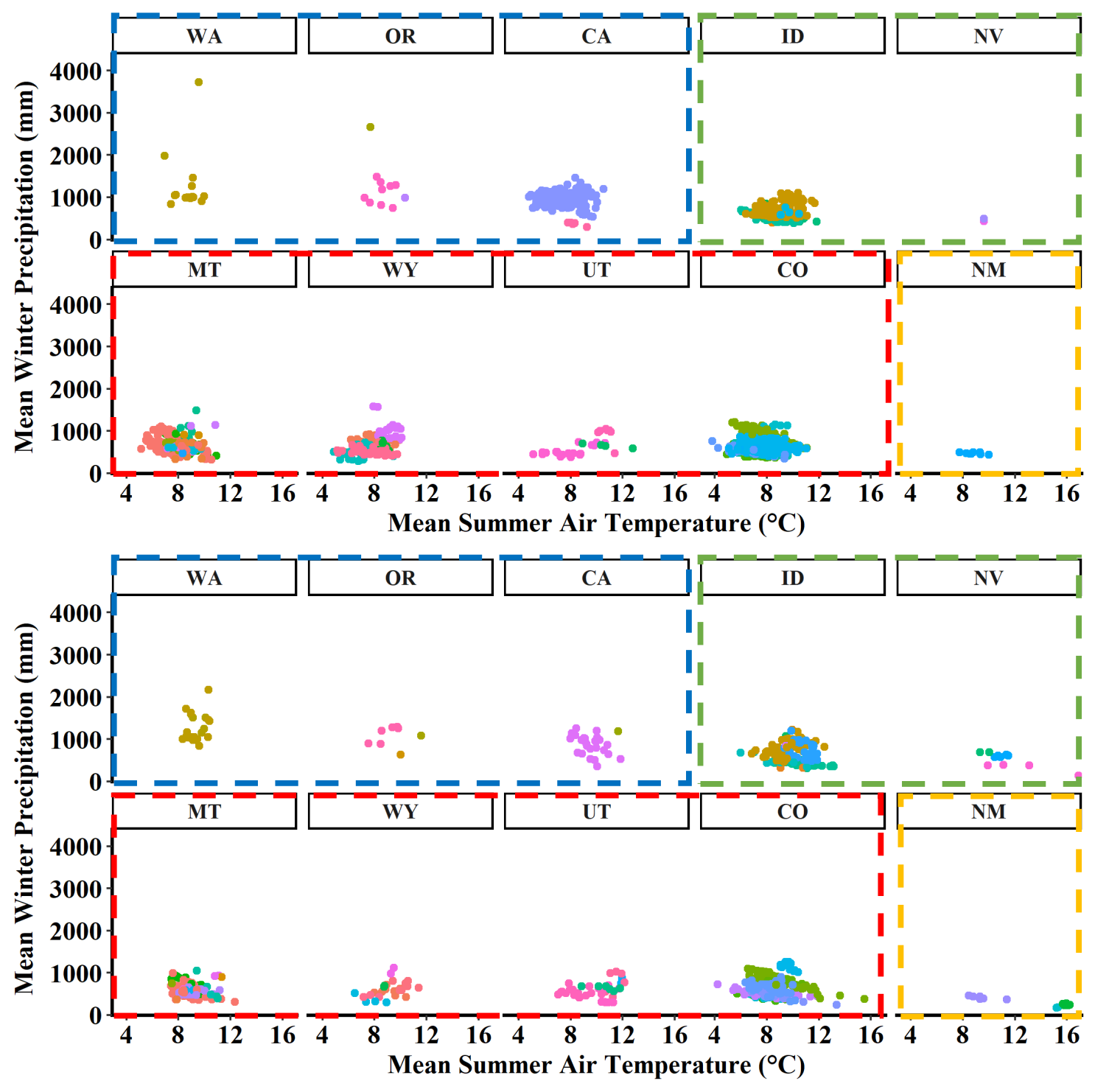

Figure E-8: Winter precipitation and summer temperature of rock glaciers (active-top, inactive-bottom) for each state. Color represents mountain ranges. Dashed borders represent states bordered in a north-south direction. 

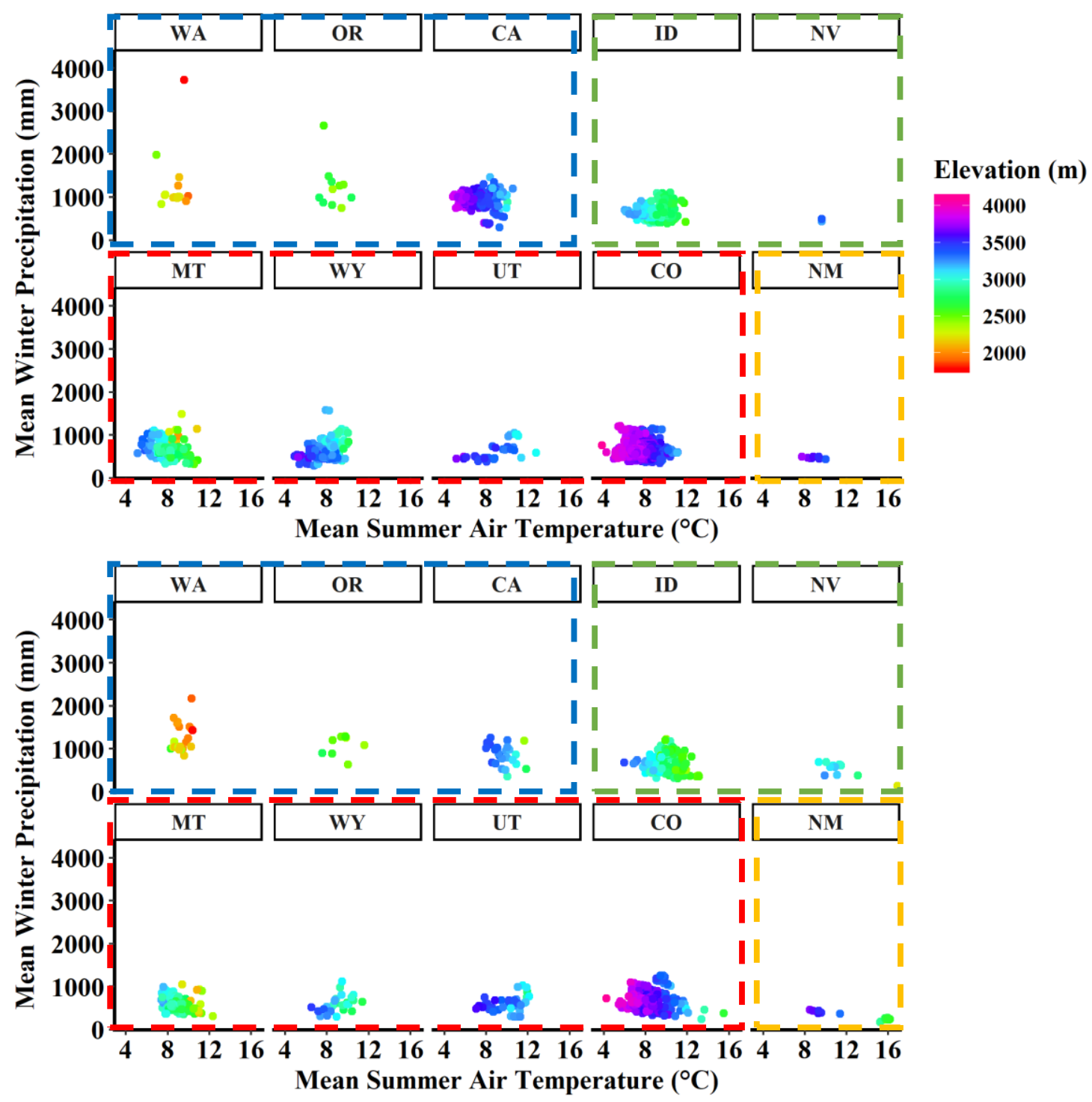

Figure E-9: Winter precipitation and summer temperature of rock glaciers (active-top, inactive-bottom) for each state. Color represents elevation. Dashed borders represent states bordered in a north-south direction.

Table E-2: Water and ice volume of rock glaciers for each state and range.

\begin{tabular}{lrlllll} 
& & \multicolumn{2}{c}{$\begin{array}{c}\text { Ice Volume } \\
50 \%(\mathrm{~km})\end{array}$} & \multicolumn{2}{c}{ Water Volume } \\
\cline { 3 - 7 } & Active/ & & & & \\
& Inactive & Mean & Total & Mean & Total \\
\hline State/Range & $\mathbf{2 3 5} / \mathbf{2 7}$ & $\mathbf{0 . 0 0 4 8}$ & $\mathbf{1 . 2 4 7}$ & $\mathbf{0 . 0 0 4 3}$ & $\mathbf{1 . 1 2 2}$ \\
\hline California & $229 / 26$ & 0.0048 & 1.215 & 0.0043 & 1.094 \\
Sierra Nevada & $6 / 0$ & 0.0044 & 0.027 & 0.0040 & 0.024 \\
White Mts. & & & & &
\end{tabular}




\begin{tabular}{|c|c|c|c|c|c|}
\hline Cascades-Trinity Alps & $0 / 1$ & 0.0053 & 0.005 & 0.0048 & 0.005 \\
\hline Colorado & $698 / 265$ & 0.0031 & 3.030 & 0.0028 & 2.727 \\
\hline Front Range & $75 / 39$ & 0.0029 & 0.326 & 0.0026 & 0.293 \\
\hline Mosquito-Gore Ranges & $55 / 18$ & 0.0027 & 0.194 & 0.0024 & 0.175 \\
\hline Sawatch Range & $140 / 54$ & 0.0029 & 0.563 & 0.0026 & 0.506 \\
\hline Elk-West Elk Mts. & $130 / 56$ & 0.0041 & 0.771 & 0.0037 & 0.694 \\
\hline Park Range & $5 / 15$ & 0.0023 & 0.046 & 0.0021 & 0.041 \\
\hline Flat Tops Range & 9/21 & 0.0023 & 0.068 & 0.0020 & 0.061 \\
\hline Sangre de Christo Mts. & $37 / 17$ & 0.0036 & 0.196 & 0.0033 & 0.176 \\
\hline San Juan Mts. & $247 / 45$ & 0.0030 & 0.867 & 0.0027 & 0.780 \\
\hline Idaho & 208/143 & 0.0026 & 0.909 & 0.0023 & 0.818 \\
\hline Lemhi Range & $39 / 45$ & 0.0024 & 0.198 & 0.0021 & 0.178 \\
\hline \multicolumn{6}{|l|}{ Henryslake-Eastern Centennial } \\
\hline Mts. & $1 / 1$ & 0.0050 & 0.010 & 0.0045 & 0.009 \\
\hline Bitterroot Range & $0 / 1$ & 0.0008 & 0.001 & 0.0007 & 0.001 \\
\hline Beaverhead Range & $1 / 2$ & 0.0023 & 0.007 & 0.0021 & 0.006 \\
\hline Lost River Range & $40 / 9$ & 0.0026 & 0.129 & 0.0024 & 0.116 \\
\hline wooth-Pioneer Ranges & $122 / 56$ & 0.0028 & 0.497 & 0.0025 & 0.448 \\
\hline Salm & $5 / 28$ & 0.0019 & 0.063 & 0.0017 & 0.057 \\
\hline Seven D & $0 / 1$ & 0.0030 & 0.003 & 0.0027 & 0.003 \\
\hline Montana & 200/124 & 0.0051 & 1.658 & 0.0046 & 1.492 \\
\hline \multicolumn{6}{|l|}{ Gallatin-Madison-Gravelly } \\
\hline Ranges & $30 / 21$ & 0.0050 & 0.255 & 0.0045 & 0.229 \\
\hline Beartooth Mts.-Absaroka Range & $110 / 71$ & 0.0064 & 1.153 & 0.0057 & 1.038 \\
\hline Lewis Range & $6 / 4$ & 0.0022 & 0.022 & 0.0020 & 0.020 \\
\hline Swan Range & $2 / 2$ & 0.0023 & 0.009 & 0.0021 & 0.008 \\
\hline ot Range & $2 / 1$ & 0.0044 & 0.013 & 0.0040 & 0.012 \\
\hline & $8 / 19$ & 0.0032 & 0.086 & 0.0029 & 0.078 \\
\hline Little Belt Mts. & $0 / 1$ & 0.0120 & 0.012 & 0.0108 & 0.011 \\
\hline Belt Mts. & $14 / 1$ & 0.00 & 0.034 & 0.0 & 0.031 \\
\hline Root Range & $10 / 1$ & 0.0016 & 0.018 & 0.0015 & 0.016 \\
\hline Pione & $7 / 2$ & 0.0031 & 0.028 & 0.0028 & 0.025 \\
\hline Beaverhead Mts. & $11 / 1$ & 0.0023 & 0.027 & 0.0020 & 0.025 \\
\hline New Mexico & 8/18 & 0.0019 & 0.049 & 0.0017 & 0.044 \\
\hline Sangre de Cristo Mts. & $8 / 6$ & 0.0022 & 0.031 & 0.0020 & 0.028 \\
\hline Gallinas-Capitan-Carrizo Mts. & $0 / 10$ & 0.0017 & 0.017 & 0.0015 & 0.015 \\
\hline Magdelena-San Mateo Mts. & $0 / 2$ & 0.0003 & 0.001 & 0.0003 & 0.001 \\
\hline Nevada & 2/11 & 0.0043 & 0.056 & 0.0039 & 0.050 \\
\hline \multicolumn{6}{|l|}{ Toiyabe-Toquima-Silver Peak } \\
\hline Ranges & $1 / 4$ & 0.0071 & 0.035 & & 0.032 \\
\hline Snake Mts. & $1 / 0$ & 0.0063 & 0.006 & 0.0056 & 0.006 \\
\hline Ruby Mts. & $0 / 5$ & 0.0016 & 0.008 & 0.0014 & 0.007 \\
\hline Jarbridge Mts. & $0 / 2$ & 0.0032 & 0.006 & 0.0029 & 0.006 \\
\hline
\end{tabular}




\begin{tabular}{lrllll} 
Oregon & $\mathbf{1 1 / 9}$ & $\mathbf{0 . 0 0 1 7}$ & $\mathbf{0 . 0 3 3}$ & $\mathbf{0 . 0 0 1 5}$ & $\mathbf{0 . 0 3 0}$ \\
Steens Mts. & 1 & 0.0018 & 0.002 & 0.0016 & 0.002 \\
Wallowa Mts. & $9 / 7$ & 0.0017 & 0.027 & 0.0015 & 0.024 \\
Blue Mts. & $0 / 1$ & 0.0014 & 0.001 & 0.0012 & 0.001 \\
Cascade Range & $1 / 1$ & 0.0015 & 0.003 & 0.0013 & 0.003 \\
\hline Utah & $\mathbf{3 4 / 3 9}$ & $\mathbf{0 . 0 0 2 6}$ & $\mathbf{0 . 1 8 8}$ & $\mathbf{0 . 0 0 2 3}$ & $\mathbf{0 . 1 6 9}$ \\
Raft River-Bear River Ranges & $0 / 2$ & 0.0009 & 0.002 & 0.0008 & 0.002 \\
Wasatch Range & $7 / 6$ & 0.0034 & 0.044 & 0.0030 & 0.039 \\
Tushar-Escalante-Boulder Mts. & $4 / 10$ & 0.0014 & 0.020 & 0.0013 & 0.018 \\
Unita Mountians & $19 / 15$ & 0.0031 & 0.104 & 0.0027 & 0.093 \\
La Sal Mts. & $4 / 6$ & 0.0019 & 0.019 & 0.0017 & 0.017 \\
\hline Washington & $\mathbf{1 5} / \mathbf{2 3}$ & $\mathbf{0 . 0 0 3 3}$ & $\mathbf{0 . 1 2 4}$ & $\mathbf{0 . 0 0 2 9}$ & $\mathbf{0 . 1 1 1}$ \\
Cascade Range-Southern & $2 / 5$ & 0.0049 & 0.034 & 0.0044 & 0.031 \\
Cascade Range-Northern & $13 / 18$ & 0.0029 & 0.090 & 0.0026 & 0.081 \\
\hline Wyoming & $\mathbf{1 5 3 / 2 6}$ & $\mathbf{0 . 0 0 5 1}$ & $\mathbf{0 . 9 2 0}$ & $\mathbf{0 . 0 0 4 6}$ & $\mathbf{0 . 8 2 8}$ \\
Beartooth Mts.-Absaroka Range & $36 / 8$ & 0.0069 & 0.305 & 0.0062 & 0.274 \\
Bighorn Mts. & $4 / 0$ & 0.0055 & 0.022 & 0.0049 & 0.020 \\
Owl Creek Mts. & $33 / 4$ & 0.0043 & 0.159 & 0.0039 & 0.143 \\
Teton Range & $20 / 2$ & 0.0062 & 0.135 & 0.0055 & 0.122 \\
Gros Ventre Range & $12 / 2$ & 0.0031 & 0.044 & 0.0028 & 0.039 \\
Wind River Range & $47 / 3$ & 0.0046 & 0.232 & 0.0042 & 0.209 \\
Wyoming Range & $1 / 7$ & 0.0029 & 0.023 & 0.0026 & 0.021 \\
\hline Total & $\mathbf{1 5 6 4} / \mathbf{6 8 5}$ & $\mathbf{0 . 0 0 3 7}$ & $\mathbf{8 . 2 1 3}$ & $\mathbf{0 . 0 0 3 3}$ & $\mathbf{7 . 3 9 2}$ \\
\hline
\end{tabular}




\section{Appendix F Features of Interest (FOI)}

Table F-1: Summary of the elevation of features of interest for each state and mountain range. Max represents maximum, min is minimum.

\begin{tabular}{|c|c|c|}
\hline State/ Range & Number & Mean Elevation (m) \\
\hline California & 679 & 3329 \\
\hline Sierra Nevada & 632 & 3351 \\
\hline White Mts. & 21 & 3561 \\
\hline Cascades-Trinity Alps & 11 & 2586 \\
\hline Warner Mts. & 15 & 2631 \\
\hline Colorado & 2567 & 3572 \\
\hline San Juan Mts. & 620 & 3665 \\
\hline Sawatch Range & 789 & 3608 \\
\hline Grand Mesa & 25 & 3155 \\
\hline Flat Tops Range, & 41 & 3387 \\
\hline Sangre de Christo Mts. & 225 & 3502 \\
\hline Elk-West Elk Mts. & 410 & 3464 \\
\hline Mosquito-Gore Ranges & 179 & 3645 \\
\hline Front Range & 259 & 3519 \\
\hline Park Range & 19 & 3194 \\
\hline Idaho & 1630 & 2711 \\
\hline Salmon River Mts. & 463 & 2559 \\
\hline Boise-Sawtooth-Pioneer Ranges & 584 & 2786 \\
\hline Lemhi Range & 304 & 2781 \\
\hline Bitterroot Range & 1 & 2540 \\
\hline Lost River Range & 160 & 2886 \\
\hline Beaverhead Range & 68 & 2607 \\
\hline Selkirk Mts. & 2 & 2063 \\
\hline Seven Devils Range & 40 & 2338 \\
\hline \multicolumn{3}{|l|}{ Henryslake-Eastern Centennial } \\
\hline Mts. & 6 & 2888 \\
\hline Snake River Range & 2 & 2553 \\
\hline Montana & 974 & 2692 \\
\hline Gallatin-Madison-Gravelly Ranges & 98 & 2876 \\
\hline Bearooth-Absorka Mts. & 394 & 2889 \\
\hline Lewis Range & 81 & 2127 \\
\hline Bitterroot Range & 26 & 2443 \\
\hline Crazy-Big Belt Mts. & 116 & 2625 \\
\hline Beaverhead Mts. & 80 & 2666 \\
\hline Tobacco Root Range & 15 & 2723 \\
\hline Pioneer Mts. & 37 & 2707 \\
\hline Sapphire Range & 85 & 2565 \\
\hline Little Belt Mts & 8 & 2473 \\
\hline
\end{tabular}




\begin{tabular}{|c|c|c|}
\hline Swan Range & 29 & 2056 \\
\hline Cabinet Mts. & 3 & 1874 \\
\hline Boulder Mts. & 2 & 2135 \\
\hline New Mexico & 104 & 3316 \\
\hline Sangre de Cristo Mts. & 81 & 3527 \\
\hline Gallinas-Capitan-Carrizo Mts. & 20 & 2538 \\
\hline Magdelena-San Mateo Mts. & 3 & 2802 \\
\hline Nevada & 169 & 3009 \\
\hline Toiyabe-Toquima-Silver Peak & & \\
\hline Ranges & 45 & 3092 \\
\hline Ruby Mts. & 38 & 2964 \\
\hline Independence - Santa Rosa Mts. & 34 & 2858 \\
\hline Oregon & 80 & 2445 \\
\hline Cascade Range & 23 & 2258 \\
\hline Steens-Fremont Mts. & 9 & 2593 \\
\hline Wallowa Mts. & 43 & 2528 \\
\hline Blue Mts & 5 & 2330 \\
\hline Utah & 845 & 3213 \\
\hline Tushar-Escalante-Boulder Mts. & 53 & 3185 \\
\hline La Sal Mts. & 27 & 3246 \\
\hline Wasatch Range & 135 & 3085 \\
\hline Unita Mountains & 621 & 3245 \\
\hline Raft River-Bear River Ranges & 2 & 2646 \\
\hline Iapah Peak & 7 & 3126 \\
\hline Washington & 281 & 1986 \\
\hline Cascade Range-Northern & 235 & 2025 \\
\hline Cascade Range-Southern & 29 & 1860 \\
\hline Olympic Mts. & 17 & 1663 \\
\hline Wyoming & 523 & 3102 \\
\hline Beartooth Mts -Absaroka Range & 119 & 2955 \\
\hline Owl Creek Mts. & 71 & 3302 \\
\hline Wyoming Range & 89 & 2908 \\
\hline Wind River Range & 102 & 3321 \\
\hline Gros Ventre Range & 40 & 3060 \\
\hline Teton Range & 69 & 3008 \\
\hline Sugarloaf Mountain & 1 & 3248 \\
\hline Bighorn Mts. & 32 & 3293 \\
\hline Total & 7852 & 3110 \\
\hline
\end{tabular}




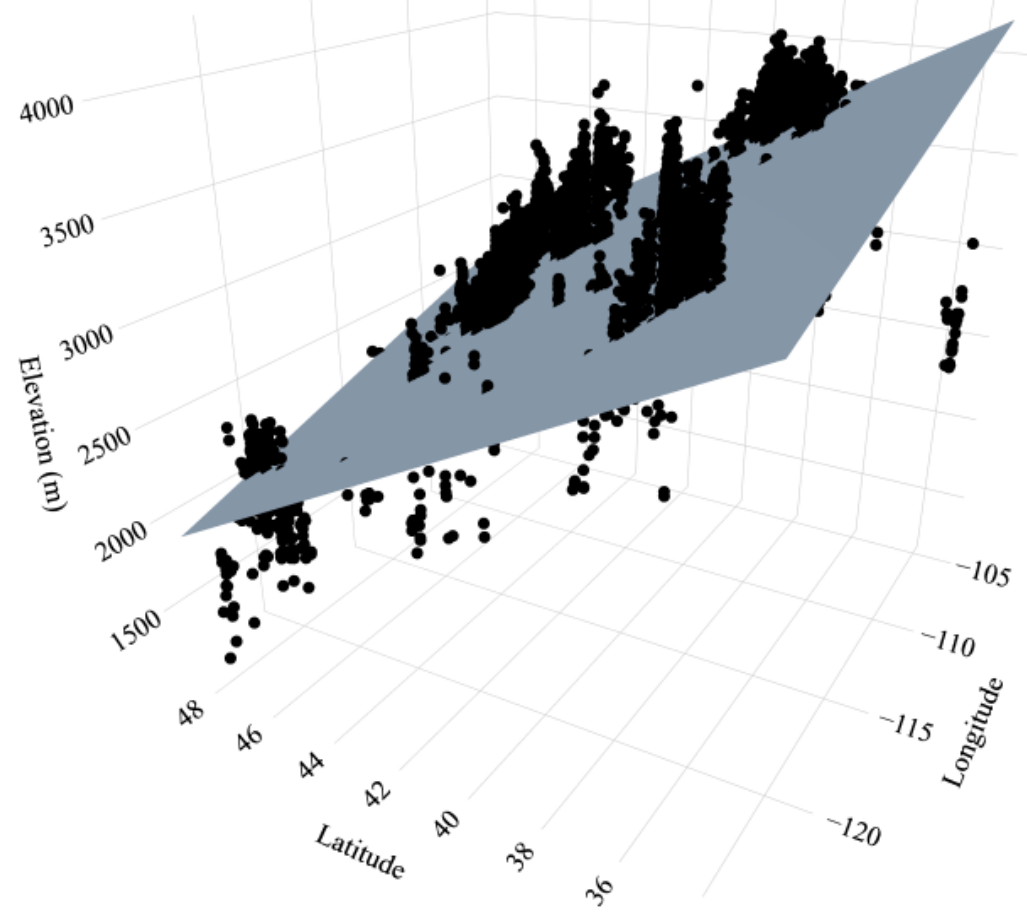

Figure F-1: Mean elevation of features of interest (FOI) in relation to its location

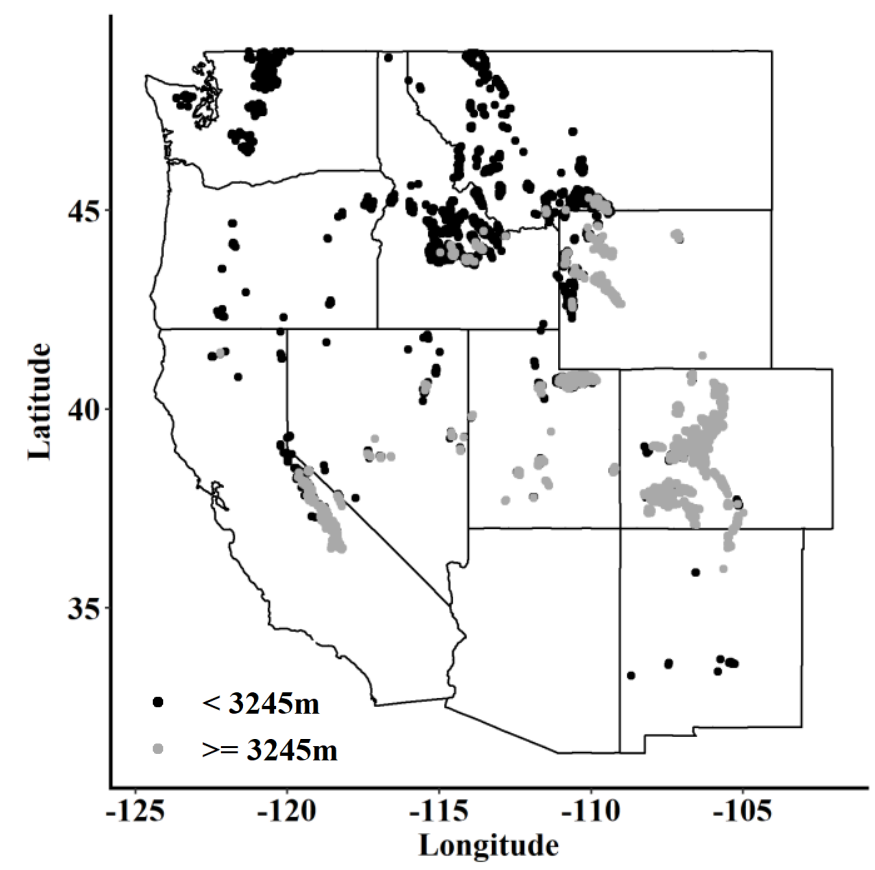

Figure F-2: The distribution features of interest (FOI) with high elevations $(>=3245 \mathrm{~m})$ and low elevations $(<3245 \mathrm{~m})$ across the western United States. 


\section{Appendix G Box plots}

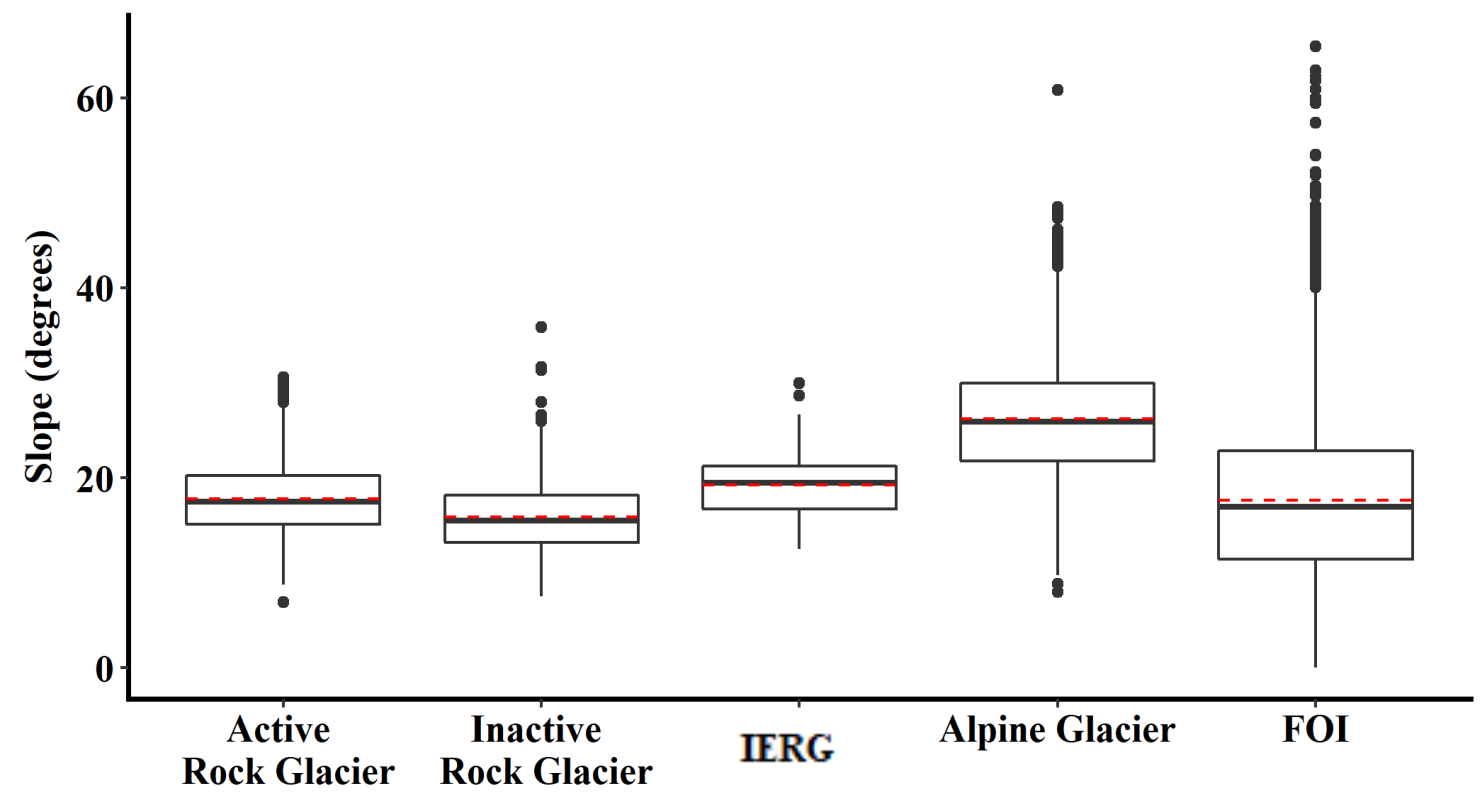

Figure G-1: Box plots of the mean slope of active and inactive rock glaciers, features of interest (FOI), exposed-ice rock glaciers (IERG), and alpine glaciers. Black line represents the mode, and dashed red line represents mean.

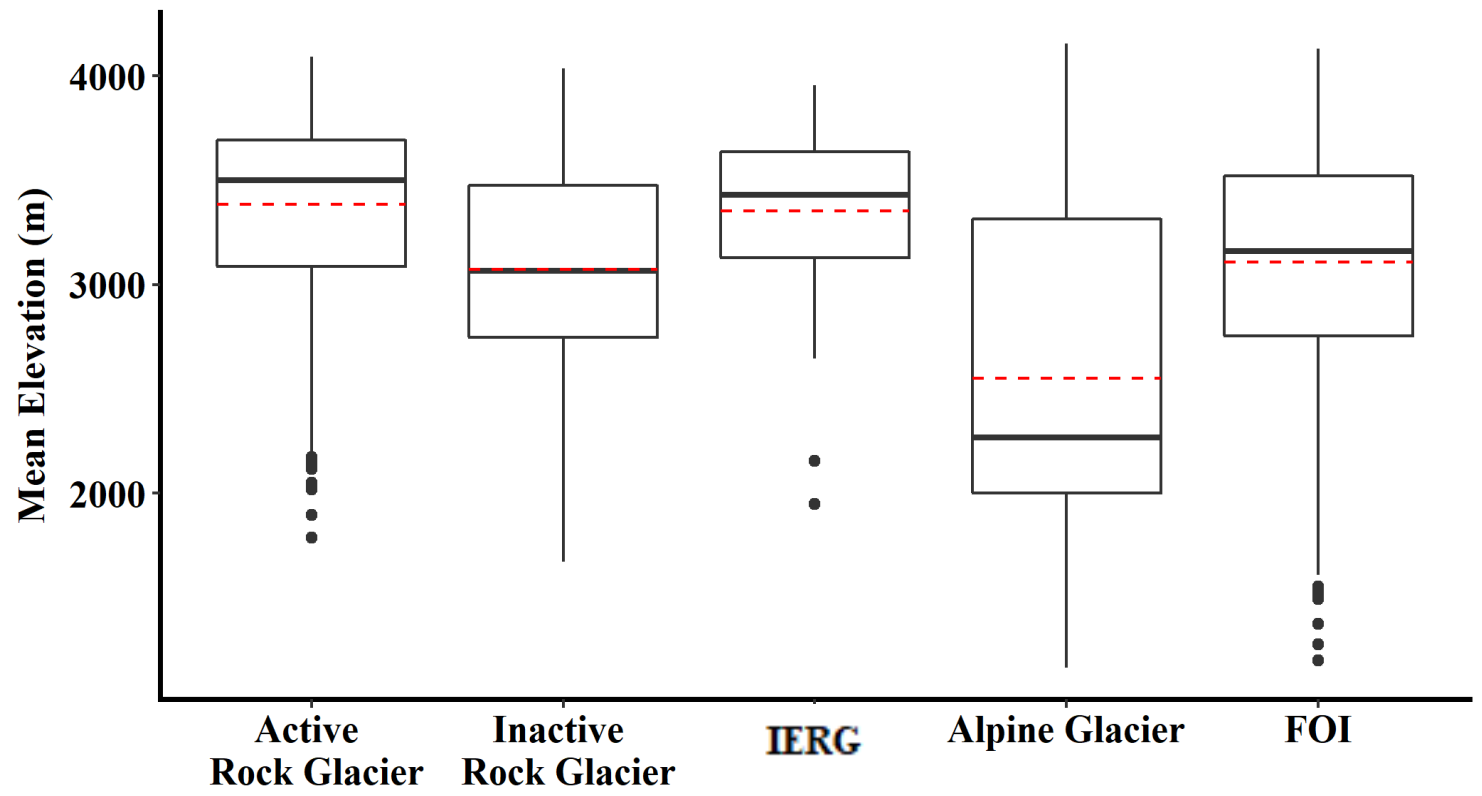

Figure G-2: Box plots of the mean elevation of active and inactive rock glaciers, features of interest (FOI), exposed-ice rock glaciers (IERG), and alpine glaciers. Black line represents the mode, and dashed red line represents mean. 


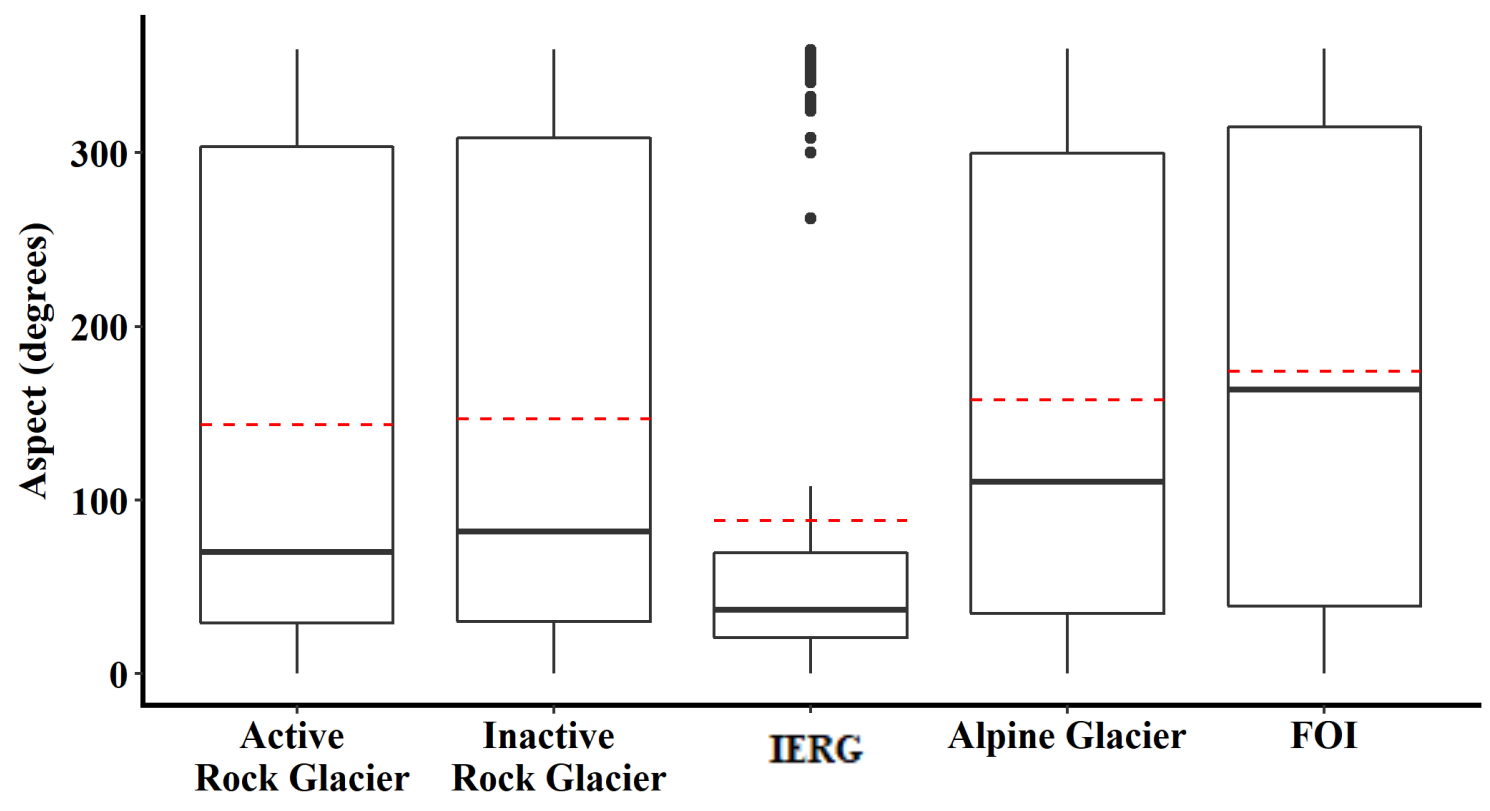

Figure G-3: Box plots of aspect of active and inactive rock glaciers, features of interest (FOI), ice-exposed rock glaciers (IERG), and alpine glaciers. Black line represents the mode, and dashed red line represents mean.

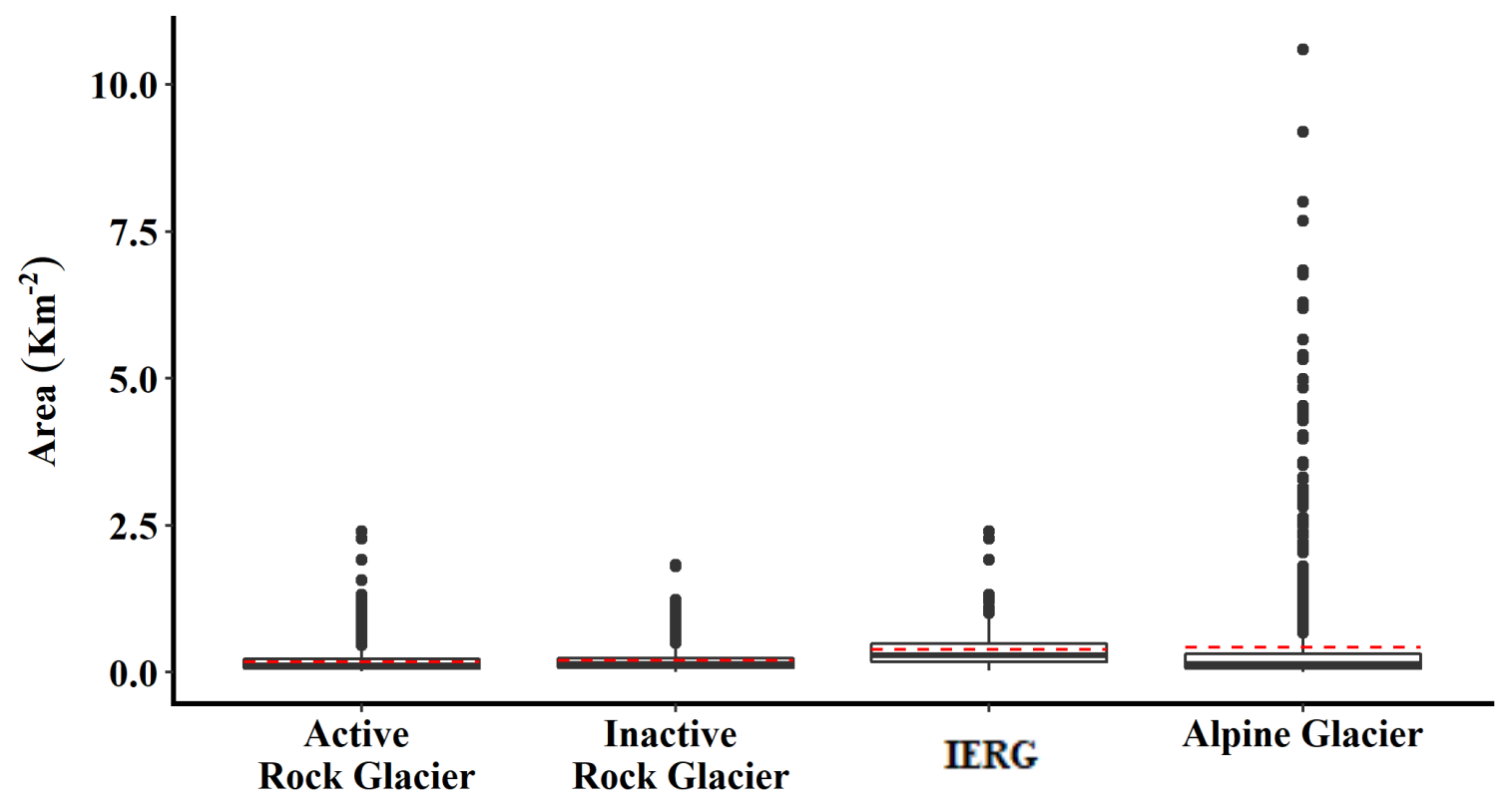

Figure G-4: Box plots of the mean area of active and inactive rock glaciers, iceexposed rock glaciers (IERG), and alpine glaciers. Black line represents the mode, and dashed red line represents mean. 


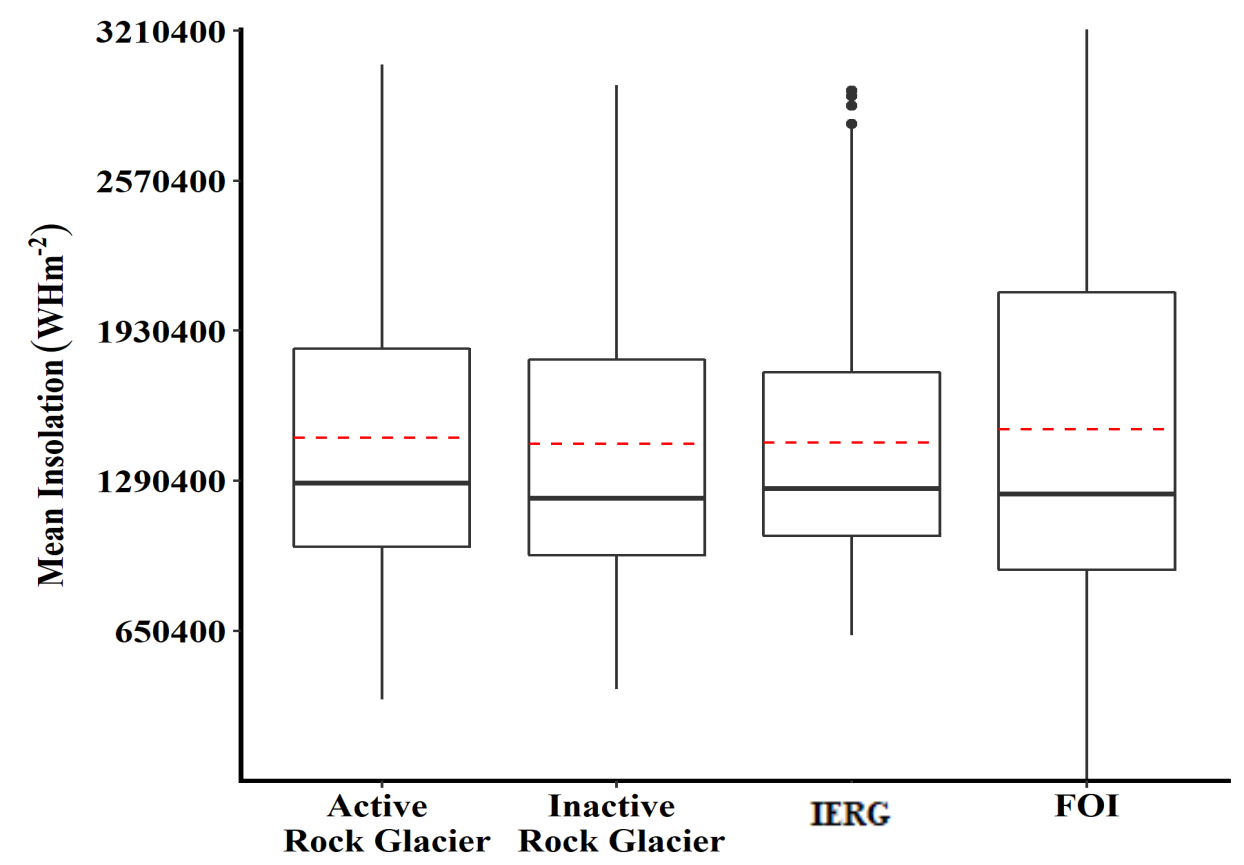

Figure G-5: Box plots of the mean insolation of active and inactive rock glaciers, features of interest (FOI), and ice-exposed rock glaciers (IERG). Black line represents the mode, and dashed red line represents mean.

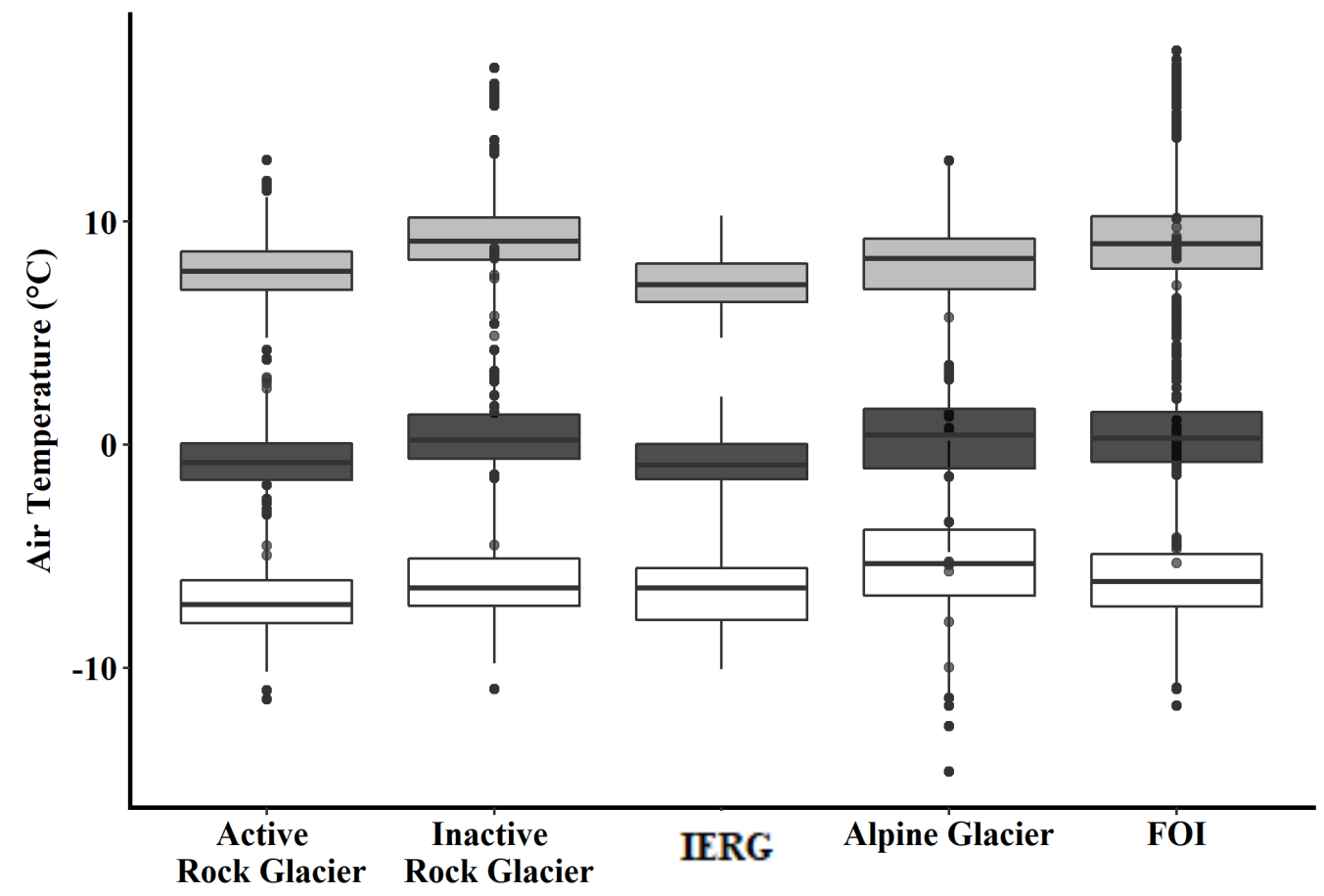

Figure G-6: Box plots of summer air temperature (grey), winter air temperature (white), and annual air temperature (dark gray) of active and inactive rock glaciers, features of interest (FOI), ice-exposed rock glaciers (IERG), and alpine glaciers. Black line represents the mode, and dashed red line represents mean. 


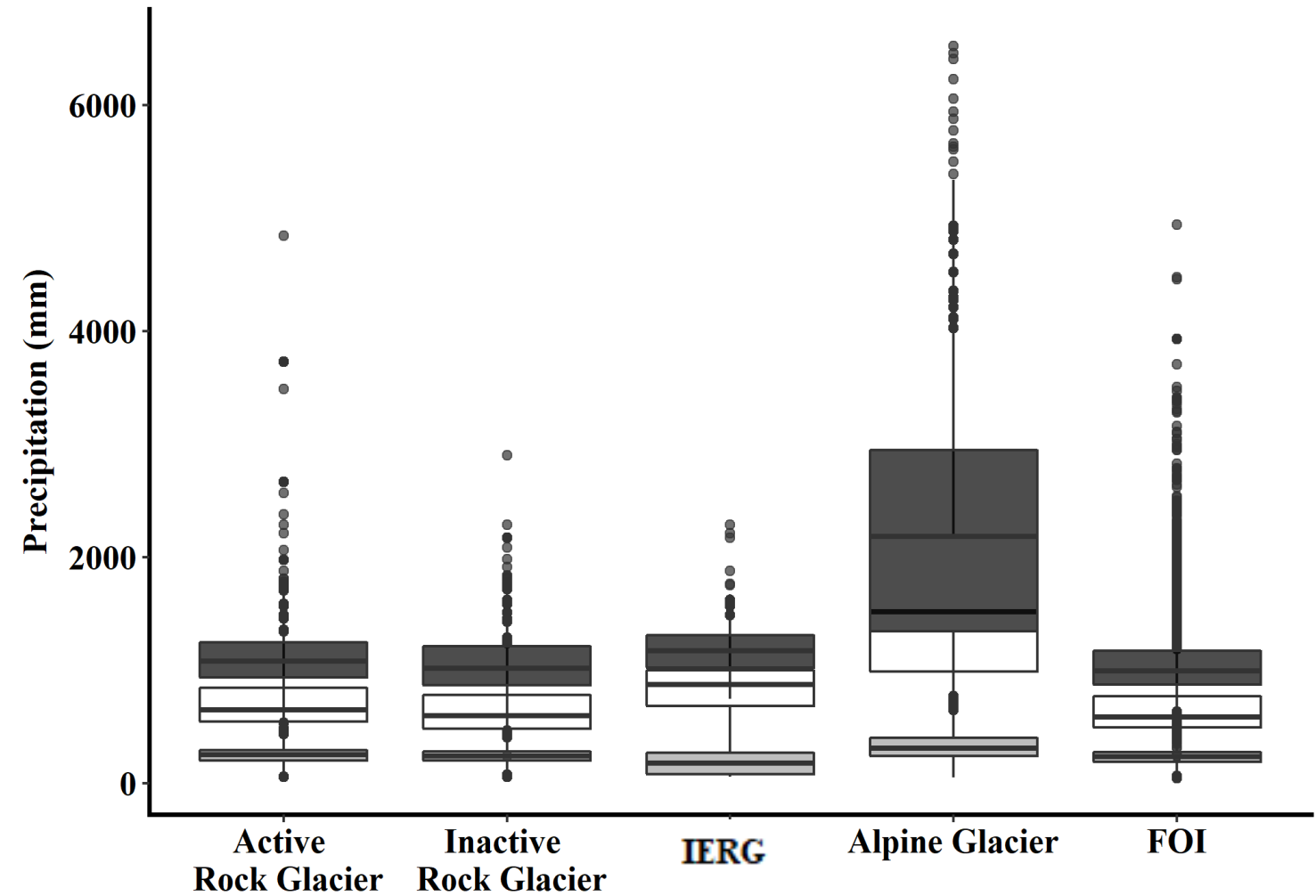

Figure G-7: Box plots of summer precipitation (grey), winter precipitation (white), and annual precipitation (dark gray) of active and inactive rock glaciers, features of interest (FOI), ice-exposed rock glaciers (IERG), and alpine glaciers. Black line represents the mode, and dashed red line represents mean. 